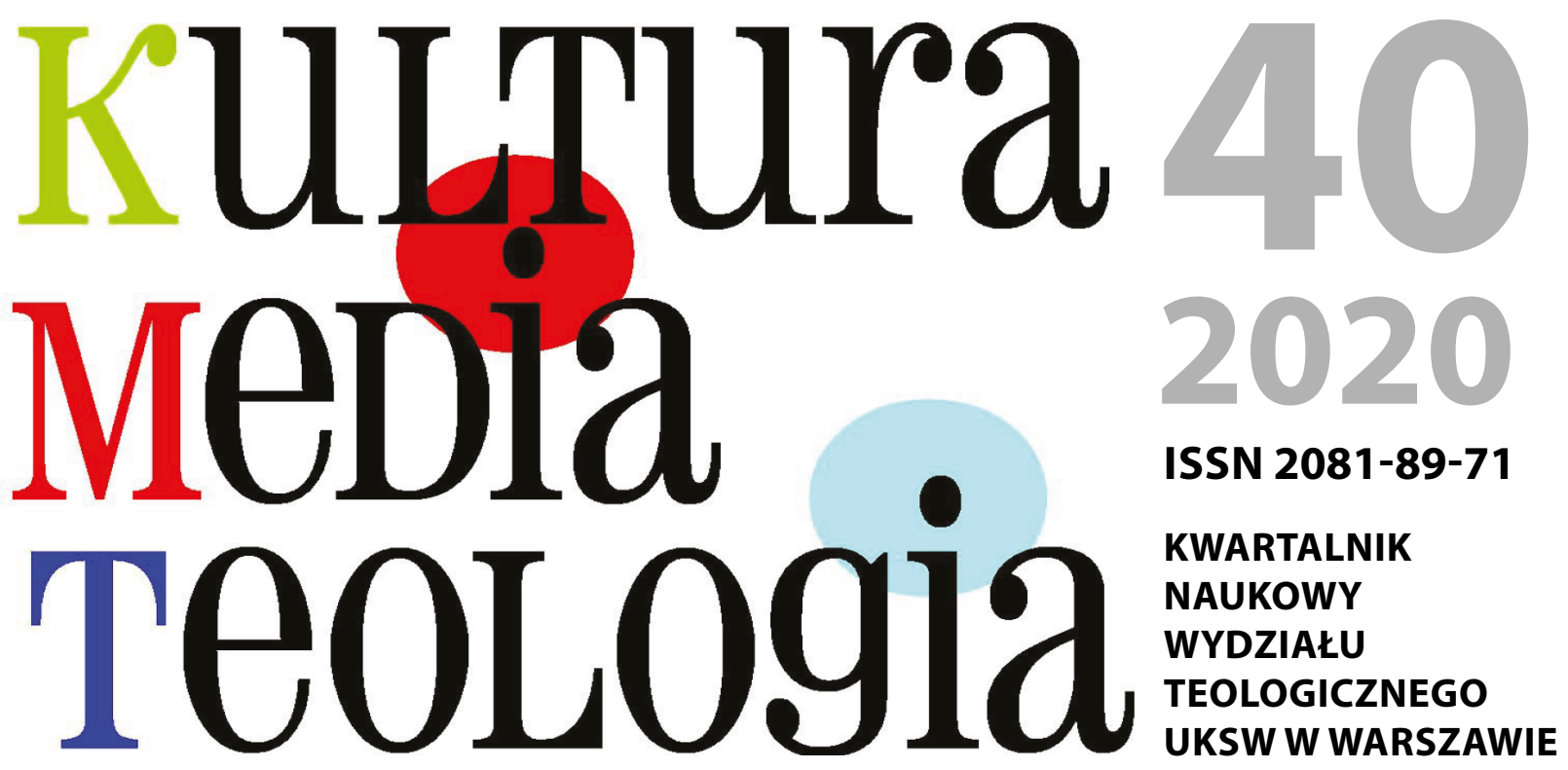





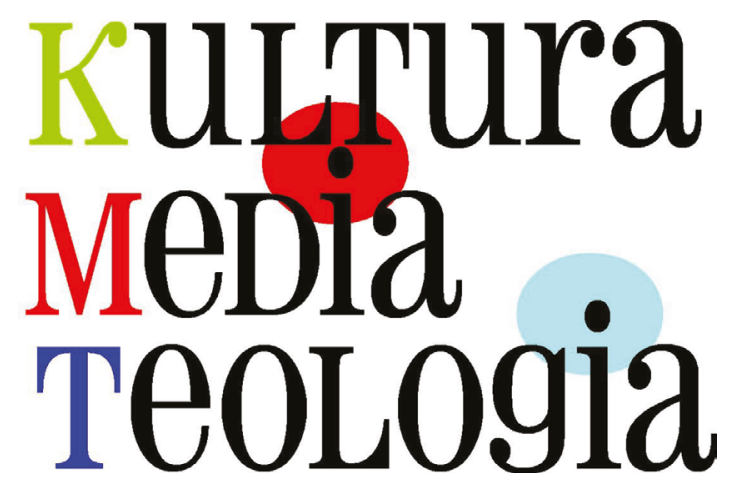

NUMER 40/2020

TEMAT NUMERU: 


\section{KULTURA - MEDIA - TEOLOGIA}

KWARTALNIK NAUKOWY WYDZIAŁU TEOLOGICZNEGO UKSW W WARSZAWIE

ISSN 2081-8971

WYDAWCA:

REDAKCJA:

Rada naukowa:

Korekta:

Skład:

Logo:

Adres redakcji:

Kontakt:
Wydział Teologiczny Uniwersytetu Kardynała Stefana Wyszyńskiego w Warszawie, ul. Dewajtis 5, 01-815 Warszawa

dr hab. Katarzyna Flader-Rzeszowska, prof. UKSW

(redaktor naczelna)

dr hab. Monika Przybysz, prof. UKSW (zastępca red. nacz.)

dr Marta Jarosz (sekretarz redakcji)

dr Marek Robak

dr Dagmara Jaszewska

ks. dr hab. Dariusz Pater

dr hab. Małgorzata Laskowska

ks. dr hab. Norbert Mojżyn

ks. prof. dr hab. Stanisław Dziekoński (UKSW)

ks. prof. dr hab. Witold Kawecki (UKSW)

ks. prof. dr hab. Henryk Seweryniak (UKSW)

prof. dr hab. Jan Stanisław Wojciechowski (UJ)

prof. dr hab. Rafał Habielski (UW)

prof. dr hab. Jerzy Olędzki (UKSW)

prof. dr hab. Anna Zeidler-Janiszewska (SWPS)

prof. dr hab. Karol Klauza (KUL)

prof. dr Michał Masłowski (Université Paris IV - Sorbonne)

Prof. Andrius Vaišnys, Uniwersytet Wileński

Doc. Mgr. Katarína Fichnová, PhD. - Uniwersytet Konstantyna

Filozofa w Nitrze (Słowacja)

dr hab. Mariola Marczak prof. UWM Olsztyn

dr hab. Anna Czajka-Cunico prof UKSW

dr Victor Khroul Państwowy Uniwersytet im. Łomonosowa

w Moskwie

dr hab. Monika Przybysz, prof. UKSW

i dr Marta Jarosz

oraz Zespół

Stanisław Tuchołka • www.panbook.pl

ks. dr hab. Andrzej Adamski, prof. WSIiZ;

fot. na okładce: https://pixabay.com/pl/photos/r\%C4\%99ce-ziemia-nast\%C4\%99pne-pokolenie-4087018/

„Kultura-Media-Teologia”, ul. Dewajtis 5, 01-815 Warszawa,

e-mail: kmt.uksw@gmail.com; http://www.kmt.uksw.edu.pl

Redakcja zastrzega sobie prawo skracania i redagowania tekstów oraz zmiany tytułów. Materiałów niezamówionych nie odsyłamy. Wersję pierwotną (referencyjną) wydawanego czasopisma stanowi publikacja online dostępna na stronie kmt.uksw.edu.pl 


\section{SPIS TREŚCI}

MEDIA

Monika Przybysz

CHALLENGES AND TASKS FOR THE PRESS SPOKESMAN AND PUBLIC RELATIONS SPECIALIST IN CRISIS SITUATIONS IN INSTITUTIONAL

COMMUNICATION IN THE CONTEXT OF THE INTERNET

Renata Matusiak

EDUKACJA MEDIALNA WE FRANCJI

KULTURA

Joanna Szydłowska

THREE STRATEGIES OF CONCEPTUALIZING SPAIN IN POLISH

21ST-CENTURY REPORTAGE. MODERNIZATION - MEMORIZATION MYTH

Witold Kawecki

FENOMEN TEOLOGII WIZUALNEJ I SPOSOBY JEJ KOMUNIKOWANIA .....

TEOLOGIA

Jacek Kiciński CMF

ŚWIĘTOŚĆ W UJĘCIU PAPIEŻA FRANCISZKA

Marcin Wrzos

APOSTOLISCHE AUSLANDSREISEN VON PAPST FRANZISKUS,

DARUNTER MISSIONSREISEN, IN DEN WICHTIGSTEN NATIONALEN

INTERNETPORTALEN (JAHR 2018)

Robert Nęcek

PRYMAS STEFAN WYSZYŃSKI JAKO MISTRZ KOMUNIKACJI.

ANALIZA SKONFISKOWANEGO WYWIADU PRASOWEGO

„KATOLICYZM W OBLICZU ZAGADNIEŃ WSPÓŁCZESNOŚCI”

UDZIELONEGO RED. JERZEMU TUROWICZOWI Z ZAMIAREM PUBLIKACJI

W „TYGODNIKU POWSZECHNYM" 



\title{
Challenges and Tasks for the Press Spokesman and Public Relations Specialist in Crisis Situations in Institutional Communication in the Context of the Internet
}

\author{
Wyzwania i zadania dla rzecznika prasowego i specjalisty \\ public relations w sytuacjach kryzysowych w komunikacji \\ instytucjonalnej w kontekście internetu
}

\begin{abstract}
SUMMARY:
Today, the Internet is an integral part of the everyday lives of many people in the world, and some of the activities of modern man are almost entirely dependent on the virtual world. Many human relationships would not exist without social media because of the long distance or the lack of physical opportunities to meet; there would be no Google maps to facilitate travel to unknown places and one could not avoid traffic jams on known routes without the Web and GPS; we would not buy many things without virtual shops; the development of artificial intelligence would not be so dynamic without Internet resources.

The list of activities that we could not undertake without virtual space is extremely

long and we can no longer imagine life without communication. The Net, as the space of communication, today serves not only the purpose of obtaining valuable information, broadening knowledge or performing duties at work, but also (or perhaps above all) of communicating with other people. The Internet and mobile devices are present in human life for several hours a day. Thanks to the Net, people move into virtual space not
\end{abstract}

only a significant part of their communication activity with friends, acquaintances and family, but also a serious part of their own existence - their experiences and reflections. It is often a task and a challenge for many institutions, because the orders of official communication and informal communication mix with each other on the Net. As a result, more and more questions are generated on the Internet, which in turn force institutions to undertake new communication strategies addressed to the environment and users of social media. A huge role in this communication is played by a public relations specialist and a press spokesman. The article is a review and its aim is to outline the issues related to communication in crisis situations and the role that the spokesman plays in crisis management. The research method is the analysis of literature available in this field, categorization of content and issues, as well as synthesis of conclusions.

\section{KEY WORDS:}

crisis management, spokesperson, internet, social media, public relations 
STRESZCZENIE:

Internet jest dziś nieodłączną częścią codziennego życia wielu osób na świecie,

a niektóre aktywności współczesnego

człowieka są niemal zupełnie zależne od wirtualnego świata. Wiele relacji

międzyludzkich nie zaistniałoby bez mediów społecznościowych z racji dużej odległości lub braku fizycznej okazji do spotkania; nie istniałyby mapy Google ułatwiające podróżowanie do nieznanych miejsc i omijanie korków na znanych trasach bez Sieci i nadajników GPS; nie kupilibyśmy

wielu rzeczy bez sklepów wirtualnych; rozwój sztucznej inteligencji nie byłby tak dynamiczny bez zasobów internetu. Lista aktywności, których nie moglibyśmy podjąć bez wirtualnej przestrzeni jest niezwykle długa i nie wyobrażamy sobie już życia bez komunikacji w Przestrzeń komunikacji, jaką jest Sieć, służy dziś nie tylko zdobywaniu cennych informacji, poszerzaniu wiedzy czy wykonywaniu obowiązków w pracy, ale także (a może przede wszystkim) komunikowaniu się z innymi ludźmi. Internet i urządzenia mobilne są obecne w życiu człowieka przez

kilkanaście godzin na dobę. Dzięki Sieci $\mathrm{w}$ wirtualną przestrzeń ludzie przenoszą nie tylko znaczny wycinek swojej aktywności komunikacyjnej ze znajomymi, przyjaciółmi, rodziną, ale także poważną część własnej egzystencji - przeżycia i przemyślenia. Często stanowi to zadanie i wyzwanie dla wielu instytucji, ponieważ w Sieci mieszają się porządki komunikacji oficjalnej z komunikacją nieformalną. W efekcie, w internecie generowane są w coraz większej liczbie pytania, które z kolei wymuszają na instytucjach podejmowanie nowych strategii komunikacyjnych adresowanych do otoczenia i użytkowników mediów społecznościowych. Ogromną rolę w tej komunikacji odgrywa specjalista public relations i rzecznik prasowy. Artykuł ma charakter przeglądowy i jego celem jest nakreślenie problematyki związanej z komunikacją w sytuacjach kryzysowych i roli, jaką rzecznik prasowy odgrywa w crisis management. Metodą badawczą jest analiza literatury dostępnej w tym zakresie, kategoryzacja treści i zagadnień, a także synteza wniosków.

\section{SŁOWA KLUCZOWE:}

zarządzanie kryzysowe, rzecznik prasowy, internet, media społecznościowe, public relations

\section{SPECIFICITY OF NETWORK COMMUNICATION IN THE CONTEXT OF INSTITUTIONAL COMMUNICATION}

The times of electronic media and Internet communities are characterized by speed of transmission, direct communication and partnership, equal treatment of every Internet user, without any hierarchy of users in terms of their real status. ${ }^{1}$ If something affects the way an Internet user is treated by an institution, it is their way of functioning on the Internet. Communication in the era of Web $2.0^{2}$ is also characterized by greater activity of message recipients and their participation in

${ }^{1} \mathrm{~J}$. Ottmar, Cyberetica: nuove sfide o vecchi problemi?, “Concilium” XLI 2005, p. 20-35.

${ }^{2}$ M. Pełechaty, Społeczności internetowe, in: K. Pankiewicz et al., E-marketing $w$ akcji, czyli jak skutecznie wzbudzać pożądanie klientów i zazdrość konkurencji, Gliwice 2008, p. 155. 
building Web content. Internet users become co-creators of the content present on the Internet and gather around common topics. Every Internet user can give vent to his or her creativity by creating, for example, an author's blog or otherwise building "their own world" on the Web. Accessibility is also a feature of modern Internet communication. Services on the Internet only rarely require payment, and most of the paid services have their free equivalents. Only the use of advanced functions of the website incurs costs. This determines the style of dialogue between the user and the institution. The idea of accessibility translates into the possibility of communication with the institution to a much greater extent and much faster on the Internet than through other channels. Hierarchy is often excluded in such communication. The Internet is also characterized by intuitiveness. Web 2.0 services usually have a clear information architecture, in which the ease of access to the content is more important than the form of its presentation. In addition, it is possible to personalize the user's Internet space in accordance with the principle of "whatever I want, wherever I want" - from informative pages to social profiles. Virtual communities also create their own initiatives, such as social loans or codeciding on the content of a given website, and finally, pathological phenomena, such as "pathostreaming." ${ }^{3}$ Observing the opportunities offered by the Web and mobile devices encourages many institutions to create a model of their own activity in the virtual space that will translate into its real success. ${ }^{4}$

Communication requirements of the contemporary audience are high. Young people in particular, who use the Internet every day, expect from institutions, but also from companies and other users a very efficient, professional discussion and dialogue, adapted to current standards. Therefore, traditional media and social media - in addition to being a unique opportunity - may also pose a threat and become a place generating crises. The Internet, by providing opportunities to share critical comments and negative opinions, is conducive to generating conflicts. This applies to all virtual relations, and therefore includes actions against the company and institutions that discredit its authority, while at the same time becoming a source of information for media journalists seeking sensation. Therefore, what

${ }^{3}$ The report of Foundation "Dajemy Dzieciom Siłę" contains many valuable analyses of this phenomenon: Patotreści w internecie. Raport o problemie, Warszawa 2019, https://fdds. pl/wp-content/uploads/2019/05/fdds-raport-patotresc-www.pdf, 29.09.2019.

${ }^{4}$ A. McAfee, Firma 2.0. Sukces dzięki nowym narzędziom internetowym, Warszawa 2011, p. 60 . 
counts is: the speed of reaction, ${ }^{5}$ the way one acts, but also earlier preparation for these difficult situations in terms of communication. Ultimately, it is the spokesman of a given institution who represents it at a critical moment and is then identified with the institution or company, and the words spoken by him/her become the voice of that entity. Therefore, a professional spokesperson must be able to convey the essence of the position of an institution or company in a brief form - in one sentence, as expected by journalists, who want to be able to quote them later. This voice is also what the media recipients are waiting for, as they know that it is the official position of an institution.

\section{The Internet, by providing opportunities to share critical comments and negative opinions, is conducive to generating conflicts.}

Professional communication between institutions and companies and Internet users requires teamwork. This is true both in normal times - in order to shape positive messages addressed to the environment, positive communication through the media, informing the public about the institution's activities, as well as in crisis times - to manage the flow of information in difficult situations. An effective communication policy is the result of the work of a spokesperson, a group of people from a press office, often a public relations specialist (or specialists), as well as the superiors of a given institution. Decision-makers must co-operate with the spokesperson so that neither they nor other members of the institution or company will provide media coverage in difficult situations without consulting the spokesperson. In times of crisis, an institution must speak with "one voice," be it the spokesperson or a superior, and in normal times have a good media policy, which is based on a professional communication management strategy. Today, it is necessary to prepare, coordinate, strategically plan and create professional, tailor-made and well thought-out messages. Such actions are necessary especially in the context of the functioning of social media. The activity of people representing

${ }^{5}$ A. Łaszyn, Kręte i proste ścieżki PR-owców do zawodu, in: Pierwsze ćwierćwiecze. 25 lat public relations w Polsce, ed. A. Łaszyn, D. Tworzydło, Warszawa-Rzeszów 2016, p. 103-105. 
institutions in their communication activities with their environment must take into account the ongoing changes in communication.

The issues of spokesmanship in the context of crisis situations are, inter alia, related to the following topics: the was the institution of the spokesperson is understood, as well as that of the public relations specialist; definition of the essence and function of the spokesperson; social and institutional conditions of the work of the spokesperson and the related limitations; professional and ethical competence of the spokesperson; organization of the press office; reflection on the ways

\section{In times of crisis, an institution must speak with "one voice," be it the spokesperson or a superior, and in normal times have a good media policy, which is based on a professional communication management strategy.}

and programmes and training possibilities of the spokespersons; desired personality traits of the spokespersons; model of media information management in an institution or company; determination of the relationship between the spokesperson and the superior in many dimensions of the functioning of an institution or company; issues of responsibility for communication in companies and institutions; information management, including: protection of data and information held by an institution or company; conducting "information policy"; functions performed by spokespersons in institutions or companies; proactive and reactive tools in the work of a spokesperson and a public relations specialist.

\section{PRESS SPOKESMAN AND PUBLIC RELATIONS SPECIALIST IN COMPANY OR INSTITUTION COMMUNICATION}

The multitude of models for the functioning of a press spokesperson/officer in an institution or company proves that this is an area that is still under development. There is no uniform model and no industry code of the spokesman, and the organizational practice of companies, institutions and organizations shows that the representatives of this profession have an unclear status: some of them are 
employees of public relations departments and are responsible for media relations; in other organisations they are advisers and proxies to presidents or directors (or even ministers, prime ministers or presidents) and therefore hold senior management positions; in other organisational structures, press spokespersons can work in completely different segments of the organisation, and the supervisor of a department reports to the vice-president, while the press spokesperson is much lower down the hierarchy. This translates not only into the importance and rank of such a person, access to information, the possibility to participate in meetings during which the information policy of a given unit is shaped, but also influences the level of remuneration and the way journalists treat the position. Although the spokesperson is mentioned in almost all textbooks or monograph chapters devoted to the shaping of relations with the media, sometimes this function is not even called a spokesperson, but e.g. a public relations specialist, media relations expert, press officer, PR department director, junior media officer, etc. This can be the case because in Poland the knowledge of public relations is

\section{Professional communication between institutions and companies and Internet users requires teamwork.}

still slight and theories of information flow and management of this good in many companies, institutions and organizations are not always professionally adapted. As a result, confusion between the scope of duties of a press spokesperson and a PR specialist is common.

The word "communication" comes from Latin communicare - talking, taking counsel, consulting with someone else. It is closely related to another Latin word: communitas, which means not only community of people, but also camaraderie and justice in relation to each other. ${ }^{6}$ And it is precisely this standard of communication of the press spokesperson that is important from the point of view of institutions or companies in which the spokesman should meet the highest ethical and professional expectations. The terms spokesperson and spokespersonship 
will be used in the following sense: "representing the organization externally; giving interviews on behalf of the organization; speaking publicly on behalf of the organization; image building; gaining information and management; supporting the organization's information system; implementing the organization's information policy; preparing statements from the authorities; preparing reports with external feedback, for example after the press release; monitoring the press; communicating with the media; organizing press conferences; organizing organization's authorities meetings with media representatives; developing media responses and answering phone inquires; actively working with others within the organization/company (especially marketing and sales); managing a PR; supervision over cooperating PR agencies and consulting companies; organization of events and all special projects aimed at promoting and publicizing the activity of the company or its individual parts or services or products; monitoring of materials, analysis of market behaviours of competitors and the results of promotion of the company, planning the budget of materials, control of PR expenditures; preparation of information materials, brochures, leaflets, company newspapers, internal information materials; responsibility for the tasks related to the functioning of the spokesman office; communication on the profiles of the institution or the company in social media, on the website."

The press spokesperson performs at least four basic functions: informational, interpretative, administrative-integrative, as well as educational-integrative. Using his/her knowledge, experience and competence and having at their disposal modern communication tools, including social networking sites, blogs and microblogs, Wiki tools, multimedia platforms, media monitoring, as well as positioning and optimization of the Internet presence, he/she cannot forget about the important work tool, which is the website. It enables the creation of a virtual information centre and is a reliable source of information. At the same time, a press spokesperson cannot ignore the presence of social media and focus only on cooperation with journalists of traditional media. Concern for communication in the Internet, where there are people, means also care for communication in social media. ${ }^{7}$

Working in press teams is a growing necessity in the era of social media and the presence of many communication tools (besides the official website of the

${ }^{7}$ T. Joosten, Social media fod Educators. Strategies and best practices, San Francisco CA 2012, p. $79 \mathrm{nn}$. 
institution with text, sound and multimedia files), and in addition, it is becoming a challenge and a task in the context of fast and professional communication with many fragmented groups and communities. It is particularly important in difficult, crisis or problem situations, which may be a threat to the organization or the company, if not managed properly. ${ }^{8}$ The press spokesperson, when working out, preparing and publishing information and multimedia content on the Internet, should make every effort to make this content be multiplied on the Internet. The content prepared by the spokesman should be made available free of charge to the widest possible audience, while pursuing a coherent information policy, listening carefully to the needs and expectations of both journalists and others interested in information concerning the institution. Bearing in mind the principle of communicating "with" and "towards", about transparency of information, authenticity of the message and building relationships with journalists on the basis of limited trust, the press spokesperson should use criticism as an opportunity for development and should manage crises in such a way as to turn them into success. However, this requires proactive attitude. In choosing a press spokesperson, several criteria are important for the institution, including his or her language skills, which should be of the highest quality. For the proper functioning of the press office, journalistic and public relations experience will also be very useful.

The criterion of willingness and possibility to work is also important, but for this to happen it is necessary that the performance of this function is the main professional work of the indicated person. The criterion of teamwork indicates that at least two people are needed to create an information and promotion centre of a given institution or company. It is also important to use appropriate tools and to be aware of the obligation to communicate using multimedia. Add to this the criterion of respect of superiors towards the spokesman and the requirement to speak with one voice with the superior. The financial criterion means providing the budget for the press office, everyday work and publishing press materials, as well as conducting dialogue with the environment through social media and the institution's website.

The proactive communication attitude of the spokesperson prevents the emergence of many media crises in the institution and has an impact on building positive relations not only with journalists but also with other people in its environment. The function of a spokesman is very important, because even one statement of the spokesperson may change the media coverage of a given event, 
and consequently also the course of events and the reactions of the environment to the narration in the media.

The work of a press spokesperson contributes to building relations between the institution and not only journalists, but also with its surroundings. To perform this function one needs skills, competencies and knowledge in many areas. The function of press spokesperson is a public function.

A spokesperson - in addition to knowledge of how journalists work and how the work in the media is organized - should have a range of communication skills and knowledge including the areas of: spokesmanship, public relations, journalism, negotiations, management, marketing, etc. The knowledge, experience and communication skills of the person who is responsible for hiring a press officer and exercises authority in a given unit is also essential. The superior of the institution should cooperate with the spokesperson, understand the essence of his/her activity, trust them, give them quite a lot of freedom in coordinating and managing the circulation of information in the institution, and also understand the essence and role of social media in the implementation of the mission of the company or institution.

Many professional skills and competences are required to work as a spokesperson, including but not limited to: information management skills, leadership qualities, strategic planning skills and inquisitiveness, negotiating skills and working under stress and in a fast pace (especially in crisis situations in an exceptional way, but also in everyday media service), knowledge of values and rules of professional ethics, ${ }^{9}$ team management skills, creation and organization of press office work, high level of communication skills (both verbal and non-verbal), ability to build relationships and initiate dialogue, as well as knowledge of communication in new media and use of modern information technologies. ${ }^{10}$

\section{PROACTIVE AND REACTIVE COMMUNICATION MANAGEMENT}

The practice of press spokesperson also requires professional communication tools. They can be organized into two departments - proactive, serving the daily work of the press officer and reactive, especially important in difficult and crisis

\footnotetext{
${ }_{9}^{9}$ S. Gawroński, Media relations służb mundurowych $w$ Polsce. Analiza wybranych formacji, Kraków-Rzeszów-Zamość 2011, p. 34.

${ }^{10}$ Y. De La Cierva, La comunication en tiempos de crisis, in: Ensayos sobre comunication institucional, ed. J.M. La Porte, Castel Gandolfo 2003, p. 127.
} 
situations. Modern media monitoring is essential in the daily work of the press officer - not just the press, but also electronic and social media. It is in the latter that information useful for the press officer to capture crisis situations is often published, and it is also used obtain feedback on published materials. Media monitoring is available not only through a paid service commissioned to a professional press monitoring company ${ }^{11}$ (payable depending on the number of keywords specified in the service), but also through tools available for free - e.g. Google Alerts. Another important tool in the work of a press spokesperson can be a virtual press office, where after logging in, high quality photos are available for download for publication in the media as well as many other press materials useful for media representatives. These can then result in publications that are more favourable to the institution or company. The advantage of having an online press office is that it is available 24 hours a day, even if it is not possible to contact the press spokesperson for some of the information needed for publication.

New information technologies should be integrated into the whole workflow of the website. A website is an extremely important tool for communication on the Internet, because it is a credible place, signed by the authority of institutions, and there are not many such places on the Net. It is also a cheap communication tool and it is extremely important for many recipients. Professional website in Web 2.0, optimized both in terms of content and technology, and often updated, can be a good tool for search engine positioning/marketing. Such search engine activities not only ensure high position in the natural search results, but also fill the space of the Internet with positive, good messages that inspire confidence. The website of a given institution or company should be managed by a spokesperson, because it is the spokesperson who, as the final instance, is the source of data administration and information flow.

Important proactive communication tools in the work of a press officer include traditional public relations tools, such as: traditional crisis conference, including briefings, sending information materials to journalists, and a virtual press conference using real-time data transmission technology. The latter type of communication is important in the case of non-commercial institutions, which can organize an event at low costs to inform expert journalists about an important issue,

${ }^{11}$ K. Gajdka, Rzecznik prasowy w otoczeniu mediów. Teoria i praktyka, Kraków 2012, p. 179. 
who do not have to leave the editorial office to attend a traditional conference, but can ask questions and hold dialogue on an ongoing basis. In this way, the press spokesperson can also invite bloggers, an important opinion-forming group of Internet users, to the conference, who will be happy to participate in an exclusive conference with interesting guests. However, extremely important communication tools, such as a crisis plan and crisis scenarios, despite the fact that in practice they are used in a crisis situation, should be prepared much earlier and therefore they belong to the proactive tools department. These tools play an extremely important role in the work of the spokesperson as concerns psychological background (when a media crisis breaks out the spokesperson knows what to do, and the answer must be prepared very quickly), but they are also an important determinant of professionalism in this activity. Ready scenarios of conduct (or at least outline of possible solutions) which are practised, thought out in a situation of lack of stress and time pressure, possible variants of solutions, analyzed and written down, a contact book for support services, contacts to important people in the institution, as well as ready press releases and statements, which only need a current date being inserted, are the minimum that each spokesperson should have ready in his/her desk. Most of the possible situations that may happen in an institution can be predicted in advance, and press releases and communications can be prepared before a difficult situation for an institution is published in the media.

The institution's website is a reactive tool in the work of a press officer. It is there, in a difficult situation, that the press spokesperson should publish (as soon as possible) the institution's statement on a given case. The activity of the spokesman will be much more active in this period of time due to numerous media publications and great public interest, therefore making some information available on the website, multiplying it by the stream to social media will be a practical solution for many recipients. A professional spokesperson then monitors internet forums under media publications, is ready for e-mail, telephone, personal contact, and is also active in social media, where there are official websites and channels of the institution and conducts dialogue in a partner-like manner, with respect to persons interested in a given event.

There are some challenges and tasks for the spokesperson (especially in the context of social media, in which crisis situations are growing at a very fast pace and polarisation of opinions takes place within 2-3 hours from the publication of the information), including the organization of the work of the spokesperson and 
the respect and observance of the rights of persons for whom this function exists, i.e. different audience groups. Knowledge of copyright laws, providing access to many materials on a "copyleft" basis, without reserving copyright, available for download and use by others, multiplication of messages in many channels of communication, use of the latest technologies in the work of the spokesman, building the highest possible position in the hierarchy of a given institution, participation in the activities and meetings of decision-makers, the fact that the spokesperson is one's main job, not combined with many other functions in institutions or companies, and the many competences necessary to perform this function and discussed in the paper are certain determinants of the essence of the spokesperson's function. The challenge in performing this function is not only the growing synergy of off-line and on-line crises, communication differences in traditional and social media, different types of communicators on the Internet, the availability of newer technologies on mobile devices, the generation of crises on the Internet by individual users, the management of critical entries and phenomena (e.g., the use of the Internet as a means of communicating with the public, the availability of new technologies on mobile devices, the management of critical entries and phenomena (e.g., the use of the Internet as a means of communicating with the public). This also includes methods and principles of crisis content management on one's own website or the basics of crisis web-writing, as well as professionalization of information flow in the institution, both inside and outside it.

It is possible, necessary and worth cooperating with the media, even in difficult situations. Media interest can be used to explain the position of a given institution in a specific case and although it is not a fast or easy process, it is an opportunity to show respect for the recipient, build relations with the media as a competent and prepared person.

Building relationships with journalists is not easy, and it is also important to remember that the style of their work resembles (to put it a bit colloquially) the life of a shark - it must be in constant motion in order to live, and when a little bit of blood appears somewhere - it attacks. However, the goal of working with the media is important - showing true beauty, arousing admiration, reaching out to those in front of monitors and TVs, as well as smartphones.

This concerns in particular the relations with the media world, where information, especially the negative kind, is transmitted at an extremely fast rate, often in the form of unproven news, enjoying the "glory of the news". Therefore, in view 
of this extremely rich and complex reality, it is worthwhile to draw on the achievements of PR and crisis management measures that facilitate the creation of good relations with the media. Especially in the context of the presence of social media, this is even more important, because crisis situations develop in social media at an alarmingly dynamic pace, and sometimes they are actually generated there. Skillful crisis management in social media requires compliance with specific rules and principles, originating from the world of management and practiced there.

It is necessary to take care of the information flow in an institution or a company, and to specify in each unit what is a secret and of what category and rank. Above all, in individual units it is necessary to establish at least the function of a press spokesperson, who will not be burdened with too many additional functions and will have time to perform his/her duties. This is a full-time job. Nowadays, a well-functioning organism cannot do without a person performing the function of contact with the media, who must be prepared to perform his or her function.

In the age of social media and the rapidly increasing number of published information demanding dealing with and, moreover, having in mind the demands facing spokespersons today it is important that they should have their associates and that press teams should be formed. Good relations between the organisation and the media are today the basis for shaping a positive image of the organisation and, moreover, an elementary condition for efficient information management. While the lack of proper relations between them is not very visible during the normal life of individual institutions or companies, crisis situations expose the lack of professional media relations and negatively affect the possibility of resolving the crisis. Crises paralyze the institution communication-wise and prevent its normal functioning. They also polarize the society, affect the image of the whole institution or company and may be a cause of loss of trust among people.

Therefore, professional press offices should be set up, at least of two people, so that if a person designated to communicate with the media is unable to do so, the other person can take over his or her function. Press offices should be established to shape relations with the media and through them - with the environment. The lack of units organized in this way and employing several people in many institutions and companies undoubtedly makes it difficult to have a consistent, professional and transparent information policy, which manifests itself especially in the event of a crisis situation. Registration of legal status, ensuring 
the continuity of the existence of such an office by appropriate decrees and human resources, determining the method of submitting substantive and financial reports on this activity to the superior, registering the office's trademarks, the method of conducting accreditation for journalists (various types of agreements with the media) - all these issues require consideration and demand the development of appropriate solutions, taking into account the specific character of work organization in a company or institution. It is also important to ensure adequate resources for running this office, including human and financial resources, etc.

The workload of a spokesperson and press office staff is always increased in crises and difficult situations. The changes taking place in social communication favour continuous dialogue with the environment, stakeholders and Internet users, which generates higher expectations for the institution to conduct a dialogue in social media with each Internet user separately. These changes, including the fragmentation of media and communication spaces, their convergence, as well as the popularization of new ways of communication (communication via mobile devices) and the extraordinary speed of data processing and dissemination of information, all lead to increasing demands on employees of press offices. Therefore, it is important not only to create press teams (even larger than twoperson teams, because the spokesperson himself will not be able to cope with this huge amount of work and communication challenges) $)^{12}$, but also taking care of their efficiency. It is therefore important to introduce a system of teamwork, but also a requirement that the office manager also have managerial skills to manage a team of people in a professional way. Good relations between the organization and the media are today the basis for shaping a positive image of the organization, and what is more, they are an elementary condition for efficient information management. While the lack of proper relations between the company or institution and the media is not very visible during the normal life of individual institutions and companies, crisis situations expose the lack of professional media relations and negatively affect the possibility of resolving the crisis. ${ }^{13}$ Communication crises paralyze the institution and prevent its normal functioning, polarize society, affect the image of the company or institution and may be the cause of serious consequences of various types, including economic ones.

${ }^{12}$ E. Czaczkowska, Jak powiedzieć, żeby nie powiedzieć, „Rzeczpospolita”, 4 VII 2006, p. A5.

${ }^{13}$ P. Kozyra, Kryzysowe zarządzanie w Kościele?, „Więź” nr 2 (2005), p. 58. 
Spokespersons are constantly asked to comment on current events and such expectations in today's world come not just from traditional media representatives, but also from internet and social media users. The lack of such organized press offices in many institutions and companies undoubtedly makes it difficult to hold a consistent, professional and transparent information policy.

\section{THE TASKS OF A SPOKESPERSON AND A PUBLIC RELATION SPECIALIST DURING THE CRISIS SITUATION}

There are many challenges and tasks for a press officer during a time of destabilization of an organization or company. Some entities and people from the management only then become aware of the need for a person to contact the media, representing an institution or a company. These tasks include rapid selection of an appropriate strategy; moreover, it is important to organise a press conference or any other appropriate form of contact with the interested media as soon as possible (issuing a press release, organising a briefing, etc.); analysing facts and data to control the flow of information in a crisis; establishing a uniform official company position: guaranteeing a single source of information (press office), ensuring communication with the internal environment (so that employees do not learn about a difficult situation in an organisation or institution from the media); anticipating potential accusations (also using previously prepared crisis scenarios); providing access to information for the media with the most up-to-date issues; monitoring deadlines (especially those promised to journalists) and providing feedback; continuous contact with management; avoiding emotional approaches to problems; maintaining trust in the institution, its staff and management; providing authority support; creating a crisis book with all possible crisis situations and scenarios, as well as prepared procedures and document templates (e.g. press releases); announcing corrective actions; availability in contacts with all interested parties. This conceptual work is sometimes divided between a press spokesperson and a public relations specialist, sometimes it is left to the press spokesperson only, and sometimes it is delegated to a press office if it exists. The press office is quite often responsible for: daily updating of the website and administration of the website; moderating discussions in social media profiles (Twitter, Facebook, etc.); creating a database of photographs of board members; creating a so-called crisis book - with all possible crisis situations and scenarios of their solutions, as well 
as prepared procedures and document templates (e.g.: press statements); initiating the statements for the media - making them interested in the positive topics, valuable from the point of view of the company or institution; creation of a database of experts together with telephone numbers of people who could provide opinions for the media; daily monitoring of the media; preparation of materials for the website; participation in events important from the point of view of the company or institution; cooperation with local media - establishing a common media strategy once a week; cooperation with the editors of secular press - radio, television, Internet; writing dementia and requests for explanations - responding to criticism and manipulation of media facts.

There are, however, some elements which interfere with the efforts made by the spokesperson and the press office. These include in particular: lack of trust on the part of the employer; lack of internal trust within the institution; lack of a system for managing information within the institution; and lack of classification of that information (e.g. classified information, etc.) and access to it. It is also important to note the lack of coherence of the information provided, the inadequate organisation of staff work; excessive emotions in communication; incomprehensible and non-transparent actions of the staff; financial problems and lack of transparency in the economic aspect of the institution; distant and ineffective actions on the part of staff and managers of the institution; lack of willingness on their part to take responsibility for the consequences of their actions; lack of resources to organise meetings with journalists and lack of resources to prepare professional press materials for them; lack of direct access by the spokesperson to the institution's highest-ranking superior, who is his sole superior.

\section{SUMMARY}

Many companies and institutions appointing a spokesperson often do not equip him/her with the most important tools of effective work, do not organize support in the form of a press office or even a person administering social media or a public relations specialist. This leads to the extension of the tasks of the spokesperson, who, in addition to cooperation with the media, must manage relations with other groups of the environment. Social media and websites are groups completely different from journalists, very demanding in communication, because in these spaces there is a continuous dialogue with Internet users. On the 
other hand, teamwork, even if the team is composed of only two people, is more efficient (and its effectiveness increases with the number of people employed in the press office). The press office should be responsible for the website of a given unit in terms of content. At least one other person in the press office is needed not only to administer these channels of communication, but also to undertake the obligation to provide information to journalists during the absence of the spokesperson in the office, i.e. holidays, illness, or to be able to go for an interview or visit the studio (answering phones, organizing meetings, etc.). The spokesman and the employee of the press office should not perform any other functions in the company and institution and should combine this work with other workplaces for reasons of ethics, accessibility as well as credibility and trust, ${ }^{14}$ which he/she is endowed with as a representative of the company or institution. A spokesperson should be a person who has access to full and complete information. This is necessary in order not to make mistakes in the media, to skilfully manage crisis situations, for which the person must be prepared and not be surprised by them.

\section{A spokesperson should be a person who has access to full and complete information.}

The role of the spokesperson in crisis situations cannot be overestimated and often it is up to the spokesperson and his communication skills to manage a crisis situation. With the support and cooperation of a public relations specialist in the field of communication with different groups of the environment, the spokesperson plays a key role in crisis management.

\section{BIBLIOGRAPHY}

Borkowski I., Zarzq̨dzanie sytuacjq kryzysowq w instytucjach konfesyjnych. Studium przypadku rzecznika prasowego, in: Dziennikarstwo i media. Marka, media, komunikacja, red. I. Borkowski, K. Stasiuk-Krajewska, t. 4, Wrocław 2013.

Czaczkowska E., Jak powiedzieć, żeby nie powiedzieć, „Rzeczpospolita”, 4 VII 2006, p. A5.

${ }^{14}$ M.M. Przybysz, Rzecznictwo prasowe $w$ instytucjach kościelnych $w$ Polsce $w$ kontekście mediów społecznościowych, Kielce 2013, p. 252. 
Monika Przybysz, Challenges and Tasks for the Press Spokesman and Public Relations Specialist...

De La Cierva Y., La comunication en tiempos de crisis, w Ensayos sobre comunication institucional, red. J.M. La Porte, Castel Gandolfo 2003.

Gajdka K., Rzecznik prasowy w otoczeniu mediów. Teoria i praktyka, Kraków 2012.

Gawroński S., Media relations służb mundurowych w Polsce. Analiza wybranych formacji, Kraków-Rzeszów-Zamość 2011.

Goban-Klas T., Komunikowanie masowe w nowoczesnym społeczeństwie, WarszawaKraków 1973.

Joosten T., Social media for Educators. Strategies and best practices, San Francisco CA 2012. Kozyra P., Kryzysowe zarzq̨dzanie w Kościele?, „Więź” nr 2 (2005), p. 58.

Kraków 1973.

Łaszyn A., Kręte i proste ścieżki PR-owców do zawodu, in: Pierwsze ćwierćwiecze. 25 lat public relations $w$ Polsce, red. A. Łaszyn, D. Tworzydło, Warszawa-Rzeszów 2016.

McAfee A., Firma 2.0. Sukces dzięki nowym narzędziom internetowym, Warszawa 2011.

Nęcek R., Kowalski R., Rzecznik prasowy w instytucji kościelnej. Teoria i praktyka, Kraków 2019.

Ottmar J., Cyberetica: nuove sfide o vecchi problemi?, „Concilium” XLI 2005, p. 20-35.

Pełechaty M., Społeczności internetowe, in: K. Pankiewicz i in., E-marketing $w$ akcji, czyli jak skutecznie wzbudzać pożądanie klientów i zazdrość konkurencji, Gliwice 2008.

Przybysz M., Kościół w kryzysie. Crisis management w Kościele w Polsce, Tarnów 2008.

Przybysz M.M., Rzecznictwo prasowe $w$ instytucjach kościelnych $w$ Polsce $w$ kontekście mediów społecznościowych, Kielce 2013.

Raport Fundacji Dajemy Dzieciom Siłę zawiera wiele cennych analiz tego zjawiska: Patotreści w internecie. Raport o problemie, Warszawa 2019, https://fdds.pl/wpcontent/uploads/2019/05/fdds-raport-patotresc-www.pdf, 29.01.2020.

\section{Biogram}

dr hab. Monika Przybysz, prof. UKSW - wykładowca w Instytucie Edukacji Medialnej i Dziennikarstwa UKSW w Warszawie. Specjalista ds. public relations, crisis management, reklamy i marketingu medialnego, medioznawca. Za rozprawę o zarządzaniu kryzysowym w Kościele w Polsce otrzymała nagrodę Prezesa Rady Ministrów RP. Ukończyła ze Złotą Odznaką studia podyplomowe w Uniwersytecie Warszawskim z public relations. Kierownik sekcji public relations w Polskim Towarzystwie Komunikacji Społecznej. Zastępca redaktora naczelnego kwartalnika naukowego „Kultura - Media - Teologia”. Współorganizator corocznych warsztatów dla rzeczników prasowych zakonnych i diecezjalnych od 2008 roku. Przygotowała rozprawę habilitacyjną „Rzecznictwo prasowe w instytucjach kościelnych w Polsce w kontekście mediów społecznościowych” (2013). Laureatka nagrody branży public relations „PRoton 2013”. W latach 2016-2019 roku członek Grupy Roboczej ds. etyki i standardów odpowiedzialnego prowadzenia biznesu w Ministerstwie Inwestycji i Rozwoju; 2018-2019 r. członek Grupy Roboczej ds. Społecznej Odpowiedzialności Uczelni MIiR; od 2019 członek Grupy Roboczej ds. Społecznej Odpowiedzialności Uczelni w Ministerstwie Funduszy i Polityki Regionalnej; od 2019 r. 
MEDIA

przedstawiciel Rzeczypospolitej Polskiej w zespole roboczym Social Dimension w pracach Bologna Follow-Up Group w ramach Bologna Process. Interesuje się zagadnieniami etyki, społecznej odpowiedzialności biznesu oraz zrównoważonego rozwoju w instytucjach niekomercyjnych, public relations, crisis management i social media.

E-mail: intellectus@wp.pl

ORCID: 0000-0002-9794-4010 


\title{
Renata Matusiak
}

\author{
Uniwersytet Opolski, Instytut Nauk Pedagogicznych
}

\section{Edukacja medialna we Francji}

\author{
Media education in France
}

\begin{abstract}
ABSTRAKT
Edukacja medialna stanowi ważny punkt edukacji szkolnej i całożyciowej. Po analizie literatury związanej z edukacją medialną we Francji można mówić o rozbudowanej wizji i działaniach dotyczących realizacji edukacji medialnej we Francji. Od strony praktycznej należy jednak zauważyć, że podobnie jak w Polsce, istnieją problemy $\mathrm{z}$ jej oceną, gdyż jest realizowana w ramach wielu przedmiotów. Należy zwrócić uwagę na postrzeganie edukacji medialnej we Francji jako edukacji przyszłościowej, a także na problemy trawiące jej wnętrze, jak nierównomierny dostęp do edukacji, problemy komunikacyjne i kulturowe spowodowane napływem emigrantów do dużych aglomeracji we Francji, a także wtórny analfabetyzm części potencjalnych odbiorców edukacji medialnej. W dyskusji pojawiają się także pytania dotyczące konsumpcji mediów, w tym głównie Internetu. Problemem jest też fakt, że umiejętności techniczne młodych ludzi będących częścią społeczeństwa francuskiego przewyższają rozumienie sztuki korzystania z mediów, co bardzo przypomina problem Polski w tym kontekście.
\end{abstract}

SŁOWA KLUCZOWE: edukacja medialna, edukacja medialna we Francji, kompetencje medialne.

\section{ABSTRACT}

Media education is an important point of school and lifelong education. As a result of the analysis of the literature related to media education in France, one can speak about the expanded vision and activities regarding the implementation of media education in France. From the practical point of view, however, it should be noted that, as in Poland, there are problems with its assessment, as it is implemented in many subjects. Attention should be paid to the perception of media education in France as future education, as well as problems that digest its interior, such as uneven access to education, communication and cultural problems caused by the inflow of emigrants to large agglomerations in France, as well as secondary illiteracy of some of the potential recipients of media education. Among the discussions there are also questions regarding the consumption of the media, mainly the Internet. The problem is also the fact that the technical skills of young people being part of French society will exceed the understanding of the art of using media, which reminds us very much and the problem of Poland in this context.

\section{KEYWORDS:}

media education, media education in France, media competences. 


\section{WPROWADZENIE}

Edukacja medialna to współcześnie ważny temat edukacyjno-wychowawczy. Kompetencje i umiejętności cyfrowe są elementami wymaganymi, aby funkcjonować w rzeczywistości cyberkultury i świata medialnego opartego na Internecie, który jest wielką przestrzenią w ciągłym ruchu, który implikuje jednocześnie utratę pojęcia terytorium i powstawanie mostów pomiędzy odległymi lądami. Aktywna obecność w Internecie przypomina poruszanie się po morzu - jesteśmy wszędzie i nigdzie. Przestrzeń, w której jesteśmy, jest zmienna i nie wydaje się, że mogłaby być strukturalizowana jak inne przestrzenie jakie znamy ${ }^{1}$. Internet jako popularne narzędzie komunikacji staje się przedmiotem wielu analiz, w tym też edukacji medialnej². Poznanie mediów, w tym duży nacisk kładziony na funkcjonowanie w cyberprzestrzeni powoduje, że jest to już nie wybór, a konieczność w edukacji. Taki obraz jest dostrzegany przez wszystkie kraje wysokorozwinięte, a w szczególności kraje Unii Europejskiej. Możemy wśród nich znaleźć te, które stanowią przykład dobrych praktyk w zakresie edukacji medialnej, gdyż w nich rozwój kompetencji wydaje się bardziej dynamiczny i zorganizowany, niż w pozostałych. Do takich przykładów należą Islandia ${ }^{3}$, Finlandia, Norwegia ${ }^{4}$, Wielka Brytania czy Francja ${ }^{5}$.

Jako jeden z krajów, w którym analizowana była edukacja medialna, wybrano Francję. Powodem tego było zauważenie sprzeczności związanych z realizacją edukacji medialnej. Z jednej strony praktyki francuskiej edukacji medialnej

${ }^{1}$ M.V. Rosati, S'orienter dans le virtuel, Wyd. Hermann, Paris 2012, s. 93.

${ }^{2}$ D. Bressy, Un projet pour travailler l'image et les médias, Wyd. Nord Compo, Paris 2008. D. Frau-Meigs, Socialisation des jeunes et éducation aux medias, Wyd. Eres, Toulouse 2011, S. 20.

${ }^{3}$ Zob. L. Pokrzycka, System medialny Islandii, Wyd. Wydawnictwo Uniwersytetu Marii Curie-Skłodowskiej, Lublin 2014, L. Pokrzycka, Media w Islandii. Ogólna charakterystyka, „Zeszyty prasoznawcze", t. 57, nr 3 (219), Kraków 2014, s. 507-516, L. Pokrzycka, Metody kształcenia medialnego na Islandii, „Przegląd Bałtycki”, http://przegladbaltycki.pl/2861,metody-ksztalcenia-medialnego-islandii.html, (dostęp. 8.01.2020 r.).

${ }^{4}$ Zob. L. Pokrzycka, Edukacja dziennikarska w Norwegii, „Przegląd Bałtycki”, http://przegladbaltycki.pl/3389,edukacja-dziennikarska-norwegii.html, (dostęp. 8.01.2020 r.).

${ }^{5}$ Zob. M.V. Rosati, Égarements: amour, mort et identités numériques, Wyd. Hermann, Paris 2014. M. Wieviorka, L'impératif numérique ou La nouvelle ère des sciences humaines et socials?, Wyd. CNRS editions, Paris 2013. V. Lavergne Boudier, Y. Dambach, Serious game: révolution pédagogique, Wyd. Hermes Science, Pris 2010. D. Bressy, Un projet pour travailler l'image et les médias, Wyd. Nord Compo, Paris 2008. D. Frau-Meigs, Socialisation des jeunes et éducation aux medias, Wyd. Eres, Toulouse 2011. 
pokazują, że jest ona realizowana na wysokim poziomie, o czym świadczą informacje uzyskane z badań. $\mathrm{Z}$ drugiej zaś, edukacja medialna jest zróżnicowana, jeśli chodzi o działania dla poszczególnych grup społecznych, co spowodowane jest rozbieżnościami kulturowymi i etnicznymi adresatów tych działań, co szerzej omówiono w drugiej części artykułu.

W artykule zawarto wstępną analizę edukacji medialnej we Francji, wprowadzenie do edukacji medialnej we Francji na podstawie literatury w części zdobytej podczas kwerendy bibliotecznej w paryskich bibliotekach. Celem badań było poznanie procesu realizacji edukacji medialnej we Francji. Ponadto Autorka wskazała rolę technologii w edukacji medialnej w obu krajach i skutków spowodowanych działaniami mediów, które dotykają dzieci i młodzież. Z uwagi na rozległość badań
Należy zwrócić uwagę na postrzeganie edukacji medialnej we Francji, jako edukacji przyszłościowej, a także na problemy trawiące jej wnętrze, jak nierównomierny dostęp do edukacji, problemy komunikacyjne i kulturowe spowodowane napływem emigrantów do dużych aglomeracji we Francji, a także wtórny analfabetyzm części potencjalnych odbiorców edukacji medialnej.

w tym artykule zostanie omówiony problem definicji edukacji medialnej, edukacja medialna we francuskim systemie kształcenia, polityka państwa w zakresie edukacji medialnej i wprowadzenie do problemów edukacji medialnej we Francji.

\section{ROZWAŻANIA TERMINOLOGICZNE WOKÓŁ POJĘCIA „EDUKACJA MEDIALNA"}

Dyrektywa Unii Europejskiej o audiowizualnych usługach medialnych reguluje kwestie związane z racjonalnym korzystaniem ze środków i narzędzi multimedialnych. W motywie 47 ujęte są kompetencje medialne, jednak nie ujmuje się tu 
wprost określenia edukacja medialna. Tłumaczony wprost motyw 47 określa, że „umiejętność korzystania z mediów obejmuje zdolność, wiedzę i osąd pozwalające konsumentom skutecznie i bezpiecznie korzystać z mediów. Osoby cechujące się umiejętnością korzystania z mediów potrafią dokonywać świadomych wyborów, zdają sobie sprawę z charakteru treści i usług, a także są w stanie korzystać z całego zakresu możliwości stwarzanych przez nowe technologie komunikacyjne. Umieją one lepiej chronić siebie i swoją rodzinę przed materiałami szkodliwymi lub obraźliwymi. Dlatego należy upowszechniać umiejętność korzystania z mediów we wszystkich grupach społecznych i uważnie obserwować rozwój tych umiejętności" ${ }^{6}$. W zależności od wersji językowej, w której tłumaczona jest definicja, kontekst pozostaje, jednak zmieniają się terminy określające podobne terminy. Anglojęzyczna wersja podaje w treści tego fragmentu definicję „kompetencji medialnych" (media literacy), natomiast w wersji francuskojęzycznej jest mowa o edukacji medialnej, a ujmując ściślej to twierdzenie - o „edukacji do mediów" (éducation aux média) 7 . Interesujące jest podejście Francuzów, którzy używają zwrotów do przyszłości, aby nauczyć się czegoś, co będzie im potrzebne w przyszłości. Stąd też, używane jest samo określenie: „edukacja do mediów”, czy też określenie „edukacja dla mediów”. To zauważalna potrzeba korzystania z mediów i ich rozumienia, a także ich udział w procesie życiowym i socjalizacyjnym jednostki. Wpływa to na emocje, rozumowanie, wyznawane wartości czy doświadczenia odbiorców mediów ${ }^{8}$. Z kolei, jak zostało uwidocznione powyżej, polskie tłumaczenie nie używa w ogóle żadnego z tych terminów, zasób kompetencji medialnych obejmując opisowo jako „umiejętność korzystania z mediów”.

${ }^{6}$ Motyw 47, Dyrektywa Parlamentu Europejskiego i Rady 2010/13/UE z dnia 10 marca 2010 r. w sprawie koordynacji niektórych przepisów ustawowych, wykonawczych i administracyjnych państw członkowskich dotyczacych świadczenia audiowizualnych usług medialnych (dyrektywa o audiowizualnych usługach medialnych) - wersja ujednolicona, L 95/1.

${ }^{7}$ E. Murawska-Najmiec, Organizacje międzynarodowe: edukacja medialna $w$ polityce Unii Europejskiej i UNESC, [w:] Cyfrowa przyszłość. Edukacja medialna i informacyjna w Polsce. Raport otwarcia, red. J. Lipszyc, Narodowy Instytut Audiowizualny, Fundacja Nowoczesna Polska, Warszawa 2012, s. 75, książka w wersji elektronicznej, http://nowoczesnapolska.org.pl/, data dostępu 11.01.2020 r.

${ }^{8}$ D. Frau-Meigs, Socialisation des jeunes et éducation aux medias, Wyd. Eres, Toulouse 2011, s. 7.

${ }^{9}$ E. Murawska-Najmiec, Organizacje międzynarodowe: edukacja medialna $w$ polityce Unii Europejskiej i UNESCO, [w:] Cyfrowa przyszłość..., dz. cyt. 
Literatura przedmiotowa ukazuje różne pojęcia „edukacji medialnej”, co niestety wpływa na konflikty środowisk naukowych, a przede wszystkim przekłada się na stronę pragmatyczną. Brak jednoznacznej definicji utrudnia przede wszystkim diagnozę problemów oraz podejmowanie kroków w stronę profilaktyki i przeciwdziałania negatywnym następstwom zagrożeń związanych z korzystaniem z sieci. Z jednej strony edukacja medialna w kontekście międzynarodowym obejmuje obszar pojęciowy ulegający ciągłym przeobrażeniom, z drugiej zaś modyfikacjom podlegają grupy docelowe edukacji medialnej ${ }^{10}$.

W popularnej encyklopedii mass mediów edukacja ta definiowana jest jako „(...) kierunek kształcenia, zmierzający do wyposażenia dzieci, młodzieży i osób dorosłych w określoną wiedzę i umiejętności, pozwalające na świadomy i krytyczny odbiór przekazów medialnych, w szczególności komunikatów przekazywanych przez mass media, a także na posługiwanie się mediami jako narzędziami opisywania świata, rozwoju intelektualnego i komunikowania się wzajemnego"11, natomiast $\mathrm{w}$ ujęciu Wacława Strykowskiego edukacja medialna jest procesem, który ma na celu przygotowanie do właściwego korzystania z mediów ${ }^{12}$. Krajowa Rada Radiofonii i Telewizji rozszerza tę definicję o kompetencje i umiejętności, które użytkownik mediów nabywa przez całe życie. Edukacja medialna „to proces kształtowania i upowszechniania umiejętności świadomego i krytycznego korzystania ze środków społecznego przekazu we wszystkich grupach społecznych oraz wiekowych. Proces edukacji medialnej to działania, które powinny trwać przez całe życie, ponieważ formy i technologie przekazu ulegają zmianom, a ponadto społeczeństwo także ulega ciągłym przeobrażeniom"13. Edukacja medialna jest wiodącą kompetencją, stanowiąc jednocześnie odpowiednik umiejętności czytania i pisania, a jej brak jest przesłanką do wykluczenia społecznego ${ }^{14}$.

10 Tamże, s. 75.

${ }^{11}$ J. Skrzypczak, Popularna encyklopedia mass mediów, Wydawnictwo Kurpisz, Poznań 1999 , s. 117.

${ }^{12}$ W. Strykowski, Media i edukacja medialna $w$ tworzeniu współczesnego społeczeństwa, [w:] Media i edukacja $w$ dobie integracji, red. W. Strykowski, W. Skrzydlewski, Wydawnictwo eMPi2, Poznań 2002, s. 19.

${ }^{13}$ A. J. Dąbrowska, P. Drzewiecki, J. Jasiewicz, J. Lipszyc, G. D. Stunża, Konwergencja kompetencji - definicja edukacji medialnej i informacyjnej, [w:] Cyfrowa przyszłość..., s. 10.

${ }^{14}$ E. Murawska-Najmiec, Organizacje międzynarodowe: edukacja medialna w polityce Unii Europejskiej i UNESCO, [w:] Cyfrowa przyszłość..., s. 12. 
W języku francuskim termin „edukacja medialna” jest rozpatrywany jako „edukacja do mediów”, co jednoznacznie wskazuje na zawężenie tego pojęcia tylko do jednego ze składników edukacji medialnej. Obok edukacji do mediów, edukację medialną rozpatruje się jeszcze w odniesieniu do edukacji poprzez media oraz edukacji o mediach. W rozważaniach terminologicznych należy jednak uwzględnić pełny kontekst oraz wieloaspektowy wymiar edukacji medialnej, która odwołuje się do tego, co jest najistotniejsze, czyli podobnie jak w polskim systemie - wychowania do odbioru mediów. Tak rozumiane wychowanie jest efektem kształcenia w zakresie wszystkich trzech komponentów, poprzez media i do odbioru mediów ${ }^{15}$.

\section{EDUKACJA MEDIALNA WE FRANCUSKIM SYSTEMIE KSZTALCENIA}

W świetle przepisów regulujących system kształcenia we Francji edukacja mająca na celu opanowanie technologii informacyjno-komunikacyjnych jest czwartym $\mathrm{z}$ siedmiu filarów podstawy programowej ${ }^{16}$. Ponadto edukacja medialna znalazła swoje zastosowanie $\mathrm{w}$ podstawie programowej w filarze szóstym dotyczącym kompetencji społecznych i obywatelskich. Jednym z jego umiejętności jest bycie wyedukowanym do mediów, bycie świadomym miejsca, które media zajmują wśród społeczeństwa, a także wpływu na społeczeństwo ${ }^{17}$. Sama edukacja medialna nie stanowi odrębnego obowiązkowego przedmiotu na żadnym z etapów kształcenia, podobnie jak w polskim systemie edukacji, kompetencje medialne są nabywane w ramach innych przedmiotów kierunkowych oraz różnych inicjatyw w środowisku pozaszkolnym. W procesie kształcenia dominuje interdyscyplinarny charakter nauczania treści z zakresu tej dziedziny, starsi uczniowie zdający maturę humanistyczną mogą ją opcjonalnie wybrać z zakresu kształcenia w ramach zajęć filmowych (audiowizualnych).

Francuski system kształcenia kładzie nacisk na kształtowanie nie tylko w zakresie wiedzy, postaw, ale również umiejętności, którymi musi wykazać się uczeń będących efektem interdyscyplinarnego przyswajania treści z zakresu edukacji

${ }^{15}$ E. Murawska-Najmiec, Francja: instytucje publiczne liderem edukacji medialnej, [w:] Cyfrowa przyszłość..., $s .159$, data dostępu 10.01.2020 r.

${ }^{16}$ Dekret nr 2006-830 z dn. 11 lipca 2006 r. ws. podstawy programowej, Décret n 2006830 du 11 juillet 2006 relatif au socle commun de connaissances et de compétences et modifiant le code de l'éducation.

${ }^{17}$ E. Murawska-Najmiec, Francja: instytucje publiczne liderem edukacji medialnej, [w:] Cyfrowa przyszłość..., s. 159-160, data dostępu 10.01.2020 r. 
medialnej i kompetencji informacyjno-komunikacyjnych. Nabywanie tych kompetencji jest certyfikowane na każdym z poziomów nauczania poprzez wydawanie stosownych dokumentów na każdym etapie kształcenia. Odrębny certyfikat „B2i” dostają uczniowie na poziomie szkoły podstawowej, gimnazjum oraz szkoły średniej. Taka polityka umożliwia w sposób sformalizowany określenie kompetencji medialnych potencjalnego użytkownika wirtualnej przestrzeni. Z uwagi na wieloaspektowy charakter kształcenia i jego interdyscyplinarność ma to zdecydowany wpływ na dalsze kształtowanie obszarów pod kątem racjonalnego przy-

\section{Francuski system kształcenia kładzie nacisk na kształtowanie nie tylko w zakresie wiedzy, postaw, ale również umiejętności, którymi musi wykazać się uczeń będących efektem interdyscyplinarnego przyswajania treści z zakresu edukacji medialnej i kompetencji informacyjno-komunikacyjnych.}

gotowania do odbioru rzeczywistości cyfrowej. Zdobycie certyfikatu na każdym z trzech etapów kształcenia wyposaża bowiem użytkownika Sieci w następujące kategorie:

a) wiedza (w której znajdują się komponenty dotyczące edukacji medialnej w szerokim tego słowa znaczeniu, uwzględniające nabycie świadomości związanej z tym, iż korzystanie z nowoczesnych kompetencji wiąże się $\mathrm{z}$ ochroną nie tylko samego siebie, ale i własności intelektualnej każdego człowieka, a także reguły dotyczące praw i obowiązków obywatelskich w tym zakresie),

b) postawa (ta kategoria warunkuje posiadanie świadomości i krytycyzmu wobec pozyskiwania i przetwarzania informacji, a także wykorzystywania ich na różnych poziomach życia oraz używania przy tym narzędzi interaktywnych), 
c) umiejętności (z zakresu obsługi nowoczesnych narzędzi technologicznych) ${ }^{18}$.

Certyfikowanie tych umiejętności zapewniło władzom francuskim przełożenie na pragmatyczne zastosowanie. Nie chodzi bowiem tu o umiejętności z zakresu korzystania i technicznych umiejętności, świadczy natomiast o luce poznawczej dotyczącej treści merytorycznych w zakresie kompetencji medialnych. Francuzi są świadomi wyższych umiejętności technologicznych swoich dzieci, zauważając przy tym jednocześnie szereg niebezpieczeństw związanych z treściami przekazywanymi w tym procesie.

Istotną rolę we wspieraniu francuskiej edukacji do mediów pełni Centre de Liaison d'Enseignement et des Medias d'Information - w dosłownym tłumaczeniu oznaczające Centrum Łączności Oświaty z Mediami Informacyjnymi. CLEMI zostało założone w 1983 roku i działa pod patronatem Ministerstwa Edukacji Narodowej we Francji jako resort Krajowego Centrum Dokumentacji Pedagogicznej. Celem centrum jest wspieranie i propagowanie prawidłowo rozumianej edukacji medialnej wśród uczniów poprzez wyposażanie ich w narzędzia adekwatne do rzeczywistych wymagań. Są to umiejętności, które uczynią uczniów „(...) kompetentnymi w odczytywaniu i odszyfrowywaniu informacji oraz obrazów, wyostrzą ich krytyczne myślenie i w końcu nauczą ich jak formułować i wyrażać własne opinie w odpowiedzialny sposób"19. W znaczący sposób działania tego resortu wpływają na pogłębienie współpracy z pedagogami i nauczycielami a osobami zajmującymi się w sposób profesjonalny mediami informacyjnymi ${ }^{20}$. Zasadniczo wpływa to nie tylko na kształtowanie świadomości medialnej uczniów, ale również przygotowuje pod względem merytorycznym środowiska pedagogów do przekazywania istotnej wiedzy w procesie kształcenia na wszystkich poziomach edukacji.

Działania Centrum mają na celu nie tylko określanie teoretycznych ram programowych skierowanych do realizacji w szkołach w postaci nowej podstawy programowej uwzględniającej kontekst edukacji do mediów, jak i przez media. Poprzez realizację swoich celów na płaszczyźnie regionalnej, jak i ogólnokrajowej,

18 Tamże, s. 160.

${ }^{19}$ Edukacja medialna - nauka cyfrowego abc, https://www.schooleducationgateway.eu/ $\mathrm{pl} / \mathrm{pub} /$ latest/practices/media-literacy--the-digital-a.htm, data dostępu 01.01.2020 r.

${ }^{20}$ M. Borkowska, E. Maurawska-Najmiec, P. Stępka, A. Woźniak, Analiza Biura KRRiT, „Organizacje międzynarodowe i wybrane państwa europejskie wobec edukacji medialne”, Biuro Krajowej Rady Radiofonii i Telewizji, nr 2/2010, s. 12. 
CLEMI poprzez sieć przedstawicieli przy kuratoriach oświaty, realizuje szkolenia dla nauczycieli, wspierając ich działalność w zakresie edukacji medialnej w sposób formacyjny. Organizując szkolenia, przygotowując materiały i narzędzia, moduły i programy pilotażowe aktywnie wpisuje się w realizację wytycznych z zakresu polityki medialnej Francji. Ważne są również działania skupione wokół działalności wydawniczej związanej z realizacją naczelnych zadań statutowych oraz wydarzeniami dotyczącymi szeroko rozumianej edukacji medialnej. Wydawnictwa to głównie publikacje książkowe, prace naukowo-badawcze, specjalistyczne periodyki oraz artykuły dotyczące historii, funkcjonowania i ekonomii mediów, socjologii mediów, działu „Młodzi a media”, analizy treści oraz analizy obrazu ruchomego i nieruchomego, a także dziennikarstwa i technik dziennikarskich oraz reklamy i Internetu, rewolucji cyfrowej i edukacji medialnej oraz pomocy dydaktycznych w tym zakresie ${ }^{21}$.

Wszystkie te działania skupiają się wokół bardzo ważnego aspektu umiejętności cyfrowych, jakim jest „(...) podnoszenie świadomości w zakresie niebezpieczeństw, jakie niesie ze sobą korzystanie z Internetu"22. Praca Centrum jest skoordynowana wokół jednolitych działań w całym kraju. Oprócz działalności mającej na celu podnoszenie kompetencji i ulepszanie warsztatu racy nauczycieli, CLEMI organizuje różnego rodzaju szkolenia i konferencje dla uczniów, które pozwalają poznać świat i kulturę mediów oraz związane z nim wyzwania.

\section{POLITYKA PAŃSTWA W ZAKRESIE EDUKACJI MEDIALNEJ}

Polityka państwowa w zakresie edukacji medialnej jest aktywnie wspierana poprzez powołaną przez rząd Komisję do Spraw Rodziny i Edukacji Medialnej. Poprzez rekomendacje w raporcie pt. „Stworzenie strukturalnej polityki w zakresie edukacji do mediów przeznaczonej dla wszystkich odbiorców" zalecane zostały następujące zadania:

a) nadanie edukacji medialnej statusu przedmiotu obowiązkowego, włączając $\mathrm{w}$ ten proces wszystkie etapy nauczania razem $\mathrm{z}$ elementarnym nauczaniem edukacji medialnej już w przedszkolu,

${ }^{21}$ Tamże, s. 12-13.

${ }^{22}$ https://www.schooleducationgateway.eu/pl/pub/latest/practices/media-literacy--the-digital-a.htm, data dostępu 10.01.2020 r. 
b) zwiększona współpraca szkoły z rodzicami w zakresie edukacji medialnej, np. poprzez utworzenie różnych inicjatyw, organizację w szkole „Dnia Rodziny i Mediów",

c) zwiększona aktywność w zakresie prowadzenia badań naukowych z zakresu edukacji medialnej,

d) utworzenie kierunku studiów wyższych oferującego kształcenie kadry specjalistycznej w zakresie edukacji medialnej,

e) motywowanie młodzieży ze szkół średnich poprzez różne formy aktywności do roli twórców mediów ${ }^{23}$.

Francja jako państwo mające etatystyczne tradycje związane z charakterem państwa, projektuje działania systemowe w zakresie edukacji medialnej. Mimo to Conseil supérieur de l'audiovisuel (CSA), organ regulacyjny do spraw audiowizualnych, nie odgrywa w tym procesie istotniejszej roli2 ${ }^{24}$. Również z uwagi na dominującą rolę państwa w kształtowaniu postaw i świadomości społecznej inicjatywy społeczne nie cieszą się dużą popularnością, zarówno ze względu na zasięg, charakter działań i całokształt przedsięwzięcia. Mimo to, znacznie więcej inicjatyw obserwuje się $\mathrm{w}$ zakresie działań związanych $\mathrm{z}$ bezpieczeństwem w Sieci oraz ochroną konsumentów w czasie korzystania z Internetu. Wśród najbardziej znanych organizacji działających na rzecz upowszechnienia edukacji medialnej można wymienić:

a) CIEM (powstały w 2002 roku) - Collectif Interassociatif Enfance et Media, w dosłownym brzmieniu „Międzystowarzyszeniowy Kolektyw na rzecz Dzieciństwa i Mediów",

b) APTE - Les écrans, les médias et nous, tłumacząc dosłownie „Ekrany, media i my",

c) organizacje walczące przeciwko agresji medialnej oraz w obronie praw obywateli. Są to R.A.P - Association Résistance à l'Aggression Publicitaire, tj. „Stowarzyszenie Oporu przeciwko Agresji Reklamowej” oraz Casseurs de $\mathrm{Pu}$ - „Pogromcy Reklamy”25.

${ }^{23}$ M. Borkowska, E. Maurawska-Najmiec, P. Stępka, A. Woźniak, Analiza Biura KRRiT, „Organizacje międzynarodowe i wybrane państwa europejskie wobec edukacji medialne”, Biuro Krajowej Rady Radiofonii i Telewizji, nr 2/2010, s. 14.

${ }^{24}$ Tamże, s. 10.

${ }^{25}$ E. Murawska-Najmiec, Francja: instytucje publiczne liderem edukacji medialnej, [w:] Cyfrowa przyszłość..., s. 164, data dostępu 01.01.2020 r. 
Francja korzysta również z regulacji związanych z przynależnością do Unii Europejskiej oraz dokumentów UNESCO. Regulacje te pozwalają na urzeczywistnianie ogólnej polityki europejskiej na rzecz mieszkańców Francji, całej Europy i świata. Polityka wewnętrzna w zakresie regulacji edukacji medialnej wciąż jeszcze skłania się raczej ku dbaniu o bezpieczne korzystanie użytkowników z zasobów świata wirtualnego oraz nowoczesnych technologii multimedialnych. Edukacja medialna, a w zasadzie edukacja do mediów, jest dość powszechnym tematem, ale jak się okazuje wciąż jeszcze niesformalizowanym. Temat ten podejmowany jest w wielu publikacjach oraz badaniach naukowych, co zdecydowanie w przyszłości przełożyć się może na działalność ściśle praktyczną, nastawioną na realizację celów z zakresu edukacji medialnej.

\section{INTERNET A EDUKACJA MEDIALNA - KONSUMPCJA I NAUKA}

Podstawowe pytanie, które zadaje Bressy, dotyczy tego, czy człowiek konsumuje media, czy się uczy się z nich, o nich, dzięki nim (w szczególności dotyczy to Internetu)? Internet ma związek z edukacją. W zasadzie to jedno z głównych mediów, które wkroczyło do szkoły i na które jest zapotrzebowanie. Postrzegane już uprzednio jako instytucjonalne (wykorzystywane w instytucjach państwowych) wkroczyło także do instytucji oświatowo-wychowawczych, czyli szkół w sposób istotny. W szczególności należy podkreślić wykorzystanie Internetu w szkole nie tylko do celów edukacyjnych, ale i komunikacyjnych ${ }^{26}$.

Można zauważyć, że w Internecie pojawiają się podobne treści, jak w kanałach telewizyjnych lub radiu, czyli reklamy, materiały publicystyczne itp. Sieć natomiast stanowi podtrzymanie powiązań pomiędzy reklamą, informacją a kulturą. Informacja jest głównym priorytetem w korzystaniu z cyberprzestrzeni - szybkość dostępu i aktualność stanowią klucz do popularności wykorzystania tego medium. Można postawić pytanie, na czym polega konsumowanie mediów w kontekście edukacji medialnej? Badacz odpowiada, że na bezkrytycznym przyswajaniu treści przez dzieci, także przez wszystkich odbiorców. Dzieci więc nie oglądają emisji przeznaczonych dla swoich kategorii wiekowych, a wszystkie przekazy, które są nadawane w chwili, w jakiej oglądają telewizję czy korzystają

${ }^{26}$ D. Bressy, Un projet pour travailler l'image et les médias, Wyd. Nord Compo, Paris 2008, s. 19. 
z Internetu. Konsumpcja treści i informacji bez podziału na jakość w przypadku dzieci jest szkodliwa wychowawczo, gdyż dziecko przyswaja elementy kultury bez zrozumienia kontekstu całości, zdobywa informacje na temat fragmentów kultury. Wiedza informacyjna w ten sposób może zaszkodzić, gdyż wykracza poza wiek dziecka, a także jego zdolności zrozumienia obrazu, tekstu, zdarzeń itd. ${ }^{27}$ Brak tu miejsca na relację z kulturą, gdyż strzępy informacji nie stanowią całości jej obrazu, a więc i nie mogą być prawidłowym nośnikiem informacji o kulturze. Berssy podkreśla, że owe strzępy informacji są wymieniane pomiędzy rówieśnikami bez udziału osób dorosłych, które mogłyby przybliżyć całość przyswajanych treści, czy wytłumaczyć konteksty zdarzeń. Internet pełni dla dzieci swego rodzaju rolę okna-obrazu na rzeczywistość, tymczasem złudne jest ufać, że poprzez monitor jesteśmy w stanie zobaczyć świat w taki sposób, jakbyśmy tam byli, czyli

\section{Media podlegają człowiekowi. To media są stworzone dla człowieka, a nie człowiek dla mediów. Człowiek ma za zadanie panować nad mediami, stąd też cała idea edukacji medialnej.}

odbierać świat i zdarzeń w taki sposób, jakbyśmy w nich uczestniczyli. Rola edukacji medialnej polega na tym, że należy zmodyfikować naukę korzystania z Internetu. Nie wystarczy tylko korzystać, uczyć umiejętności, ale poprzez komentarze, opinie uczyć możliwości odrzucenia treści, zrozumienia treści osadzonej w konkretnej sytuacji. Zadaniem edukacji, nauki medialnej jest umiejętność wykorzystania danej treści w sposób odpowiedzialny i efektywny. Dzieci bardzo szybko dostrzegają pojawiające się przekazy, treści, ale sposób ich zrozumienia polega na skutecznie realizowanej edukacji medialnej ${ }^{28}$.

${ }^{27}$ Tamże, s. 19-21.

${ }^{28}$ Tamże, s. 22. 


\section{ZAKOŃCZENIE}

Badacze francuscy edukacji związanej z mediami stoją na stanowisku, że media podlegają człowiekowi. To media są stworzone dla człowieka, a nie człowiek dla mediów. Człowiek ma za zadanie panować nad mediami, stąd też cała idea edukacji medialnej. Edukacja medialna to proces, a jednocześnie rozwiązanie długofalowe. Nie opiera się tylko na „edukacji do korzystania z Internetu”, czy jakby ujęli to Francuzi „edukacji dla korzystania z Internetu”, ale obejmuje też cały szereg innych mediów, np. edukację filmową. Jednak mocno osadzona jest w zmierzaniu ku rozwojowi sektorów publicznego, prywatnego i cywilnego ${ }^{29}$, które opierają się na nowych technologiach. Dlatego też, wymaga rozwoju, bo stanowi element przyszłości ${ }^{30}$. Wśród tych teoretycznych założeń w środowisku Francji zauważalne są nierówności w edukacji medialnej - szczególnie w dużych aglomeracjach miejskich, co jest spowodowane napływem emigrantów, którzy zaczynają stanowić liczącą się grupę w większych miastach. Edukacja medialna napotyka w takich przypadkach duże trudności w adaptacji, a także nieznajomość technologiczną w zależności od grupy. Francuski rząd wprawdzie podejmuje próby niwelowania takich trudności realizując dodatkowe programy edukacyjne skierowane do imigrantów. Trudno mówić o efektach, gdyż sytuacja ulega pogłębieniu z uwagi na zmieniającą się strukturę społeczną i zwiększającą się liczbę ludności napływowej. Inna kwestia, że we Francji, podobnie jak w Polsce, edukacja medialna to edukacja pozyskiwana na różnych przedmiotach szkolnych, więc od strony praktycznej czyni ją to trudną, jeśli chodzi o dogłębną analizę i ocenę co do efektów i ścieżki edukacjii ${ }^{31}$.

\section{BIBLIOGRAFIA}

Borkowska M., E. Maurawska-Najmiec E., Stępka P., Woźniak A., Analiza Biura KRRiT, Organizacje międzynarodowe i wybrane państwa europejskie wobec edukacji medialne, Biuro Krajowej Rady Radiofonii i Telewizji, nr 2/2010.

Bressy D., Un projet pour travailler l'image et les médias, Wyd. Nord Compo, Paris 2008.

${ }^{29}$ D. Frau-Meigs, Socialisation des jeunes et éducation aux medias, Wyd. Eres, Toulouse 2011, s. 161-176.

${ }^{30}$ Tamże, s. 37.

${ }^{31}$ Tamże, s. 182. 
Dąbrowska A., Drzewiecki P., Jasiewicz J., Lipszyc J., Stunża G. D., Konwergencja kompetencji - definicja edukacji medialnej i informacyjnej, [w:] Cyfrowa przyszłość. Edukacja medialna i informacyjna $w$ Polsce. Raport otwarcia, red. J. Lipszyc, Narodowy Instytut Audiowizualny, Fundacja Nowoczesna Polska, Warszawa 2012.

Dekret nr 2006-830 z dn. 11 lipca 2006 r. ws. podstawy programowej, Décret n 2006$830 \mathrm{du} 11$ juillet 2006 relatif au socle commun de connaissances et de compétences et modifiant le code de l'éducation.

Edukacja medialna - nauka cyfrowego abc, https://www.schooleducationgateway.eu/pl/ pub/latest/practices/media-literacy--the-digital-a.htm

Frau-Meigs D., Socialisation des jeunes et éducation aux medias, Wyd. Eres, Toulouse 2011.

Lavergne Boudier V., Dambach Y., Serious game: révolution pédagogique, Wyd. Hermes Science, Paris 2010.

Motyw 47, Dyrektywa Parlamentu Europejskiego i Rady 2010/13/UE z dnia 10 marca 2010 r. $w$ sprawie koordynacji niektórych przepisów ustawowych, wykonawczych i administracyjnych państw członkowskich dotyczacych świadczenia audiowizualnych usług medialnych (dyrektywa o audiowizualnych usługach medialnych) - wersja ujednolicona, L 95/1.

Murawska-Najmiec E., Francja: instytucje publiczne liderem edukacji medialnej, [w:] Cyfrowa przyszłość. Edukacja medialna i informacyjna $w$ Polsce. Raport otwarcia, red. J. Lipszyc, Narodowy Instytut Audiowizualny, Fundacja Nowoczesna Polska, Warszawa 2012.

Murawska-Najmiec E., Organizacje międzynarodowe: edukacja medialna $w$ polityce Unii Europejskiej i UNESC [w:] Cyfrowa przyszłość. Edukacja medialna i informacyjna w Polsce. Raport otwarcia, red. J. Lipszyc, Narodowy Instytut Audiowizualny, Fundacja Nowoczesna Polska, Warszawa 2012.

Pokrzycka L., Edukacja dziennikarska w Norwegii, „Przegląd Bałtycki”, http://przegladbaltycki.pl/3389,edukacja-dziennikarska-norwegii.html

Pokrzycka L., Media w Islandii. Ogólna charakterystyka, „Zeszyty prasoznawcze”, t.57, nr 3 (219), Kraków 2014, s. 507-516.

Pokrzycka L., Metody kształcenia medialnego na Islandii, „Przegląd Bałtycki”, http://przegladbaltycki.pl/2861,metody-ksztalcenia-medialnego-islandii.html

Pokrzycka L., System medialny Islandii, Wyd. Wydawnictwo Uniwersytetu Marii Curie-Skłodowskiej, Lublin 2014.

Skrzypczak J., Popularna encyklopedia mass mediów, Wydawnictwo Kurpisz, Poznań 1999. Strykowski W., Media i edukacja medialna w tworzeniu współczesnego społeczeństwa, [w:] Media i edukacja $w$ dobie integracji, red. W. Strykowski, W. Skrzydlewski, Wydawnictwo eMPi2, Poznań 2002.

Rosati M.V., S'orienter dans le virtuel, Wyd. Hermann, Paris 2012.

Rosati M.V., Égarements: amour, mort et identités numériques, Wyd. Hermann, Paris 2014.

Wieviorka M., L'impératif numérique ou La nouvelle ère des sciences humaines et socials?, Wyd. CNRS editions, Paris 2013. 


\section{Biogram}

Renata Matusiak (Uniwersytet Opolski) - doktor nauk społecznych w zakresie pedagogiki. W ramach zainteresowań naukowych odbyła studia podyplomowe: Kryminologia z elementami profilaktyki przestępczości, Profilaktyka społeczna i terapia uzależnień, Przygotowanie pedagogiczne. Autorka kilkunastu artykułów naukowych, przewodnicząca komitetów organizacyjnych i uczestniczka licznych konferencji o zasięgu międzynarodowym i ogólnopolskim, redaktorka monografii naukowych, organizatorka i prowadząca spotkania profilaktyczne dla dzieci i młodzieży. Specjalizuje się profilaktyce społecznej i szkolnej, problematyce mediów w wychowaniu.

e-mail: renatamatusiak@poczta.onet.eu

ORCID: 0000-0001-7035-4443 
KULTURA - MEDIA - TEOLOGIA 40/2020 


\title{
Joanna Szydłowska
}

\author{
University of Warmia and Mazury in Olsztyn
}

\section{Three strategies of conceptualizing Spain in Polish 21 st-century reportage. Modernization - memorization - myth \\ Trzy strategie konceptualizacji wizerunku Hiszpanii w reportażach polskich XXI wieku. Modernizacja - memoryzacja - mit}

\section{ABSTRACT}

The article focuses on selected elements of the image of Spain created in Polish reportage texts in the recent years. The analytical material comprises three extensive on-fiction texts published as books: Pył z landrynek. Hiszpańskie feisty [Dust of Hard Candies. Spanish Fiestas] (2013) by Katarzyna Kobylarczyk, Barcelona stolica Polski [Barcelona, the Capital of Poland] (2016) by Ewa Wysocka, and Ludzie z Placu Słońca [People from the Square of the Sun] (2017) by Aleksandra Lipczak. The undertaken analysis of imaging strategies will be limited to three fields of interpretation concerning 1) modernization processes in Spain in the recent years 2) pragmatics and instrumentalization of Spanish memory cultures 3) Spanish culture of events and searching for sacrum in laicized modern times. The article will scrutinize how cultural travel may become an intellectual inspiration and an inspiration to develop one's writing style in such non-fiction texts as reportage and travel guidebook.

KEYWORDS:

non-fiction, cultural tourism, cultural memory, Spain, Polish literature

\begin{abstract}
ABSTRAKT
Przedmiotem uwagi są wybrane elementy wizerunku Hiszpanii zapisanego w polskich tekstach reportażowych lat ostatnich. Materiałem analitycznym są trzy obszerne teksty non fiction opublikowane $\mathrm{w}$ formie książek: Katarzyna Kobylarczyk (Pył z landrynek. Hiszpańskie fiesty, 2013); Ewa Wysocka (Barcelona stolica Polski, 2016); Aleksandra Lipczak (Ludzie z Placu Słońca, 2017). Analizę strategii wizerunkowych ograniczymy do trzech pól interpretacyjnych dotyczących: 1) procesów modernizacyjnych Hiszpanii lat ostatnich; 2) pragmatyki i instrumentalizacji hiszpańskich kultur pamięci; 3) hiszpańskiej kultury eventów i poszukiwania sacrum w zlaicyzowanych czasach współczesnych. W artykule rozpatruje się, w jaki sposób podróż kulturowa może stać się inspiracją warsztatową i intelektualną dla takich tekstów non fiction jak reportaż i travel guidebook.
\end{abstract}

\section{SŁOWA KLUCZOWE:}

non fiction, reportaż, guidebook, turystyka kulturowa, pamięć kulturowa, Hiszpania, literatura polska 


\section{INTRODUCTION}

It is the aim of the proposed reflection to describe selected elements of Spain's image in Polish reportages published in the last five years. The focus will be placed on explorations which can be perceived as cultural journeys focused on intellectual and aesthetic contemplation of various (material and non-material) artefacts of culture. It will be scrutinized which elements of the symbolic imaginarium contribute to the reportage image of Spain in the Polish non-fiction literature of the recent years. Additionally, it will be investigated how modern Polish literary reportage employs genre alterations of travel guidebook.

\section{LITERATURE REVIEW}

Postmodernity blurred the sharpness of national categories in designing the modern world and triggered an offensive of identity projects based on existential values and the idea of citizenship. The shattering of the homogenous image of Poles' collective identity that occurred after 1989 strengthened the figure of the Other. In the Polish reality, the Other has always been associated particularly willingly with a German, Russian, Jew or Ukrainian. These figures of otherness have always been particularly strongly present in the Polish public discourse and in texts of culture. They have triggered debates, aroused emotions, redefined the assessment of the Polish present and past. Naturally, the subject of Spain has never stood a chance of causing such an interest and emotions. The Spanish Other has always been too far away, remaining peripheral and unknown. It has been difficult to see oneself in his mirror. The diary of literary and media facts confirms that for Poles Spain has remained a country rather poorly recognized. Magdalena Barbaruk proved that this fact has a wider European context: "does Spain play a role of the European place of »non-memory«? Is this a consequence of marginalizing Spain because of Francoist regime? Is Spain bound to be a peripheral country owing to its geographical location? Is it to be overlooked because of the civilizational and cultural gap, because of its "Africanity «?"1. Yet it is the Spain overwhelmed by civil war that became a subject of one of the most valuable Polish

${ }^{1}$ M. Barbaruk, Sensy błądzenia. La Mancha i jej peryferie, Kraków 2018, p. 18. 
reportage books in the interwar period (Ksawery Pruszyński) ${ }^{2}$ and a number of other known reports (Jędrzej Giertych; Roman Fajans; Jerzy Przedwieczerski) ${ }^{3}$. After World War II, Spain was brought closer to the Polish reader in a travel diary of Monika Warneńska ${ }^{4}$ and literary essays by Maria Kuncewiczowa ${ }^{5}$. When the Iron Curtain collapsed and Poland joined the Schengen Area, Spain became an attractive tourist destination, an object of cultural and linguistic fascinations. Late modernity, which inscribed the man into a multidimensional and unstable world, manifested itself, among others, in a boom of self-help booksphilosophy, an increase in the importance of all sorts of advisors, experts, and consultants ${ }^{6}$. These transformations - multiplied by a change in patterns of international tourism and a new figure of tourist-traveler ${ }^{7}$ - found their reflection in an incredibly wide offer of guidebooks and Baedekers, which literally flooded the Polish publishing market in the recent years ${ }^{8}$. These texts, fundamental for a tourist experience, interestingly contextualise themselves in relation to the narration of professional branding materials - those which build the image, reputation and brand of a given country ${ }^{9}$.

This type of utilitarian literature has a great power of distributing and reproducing image stereotypes. A stereotype, according to Walter Lippmann, is always a product of individual, fragmentary, schematic and simplified perceptions of a given

${ }^{2}$ K. Pruszyński, W czerwonej Hiszpanii, Warszawa 1937.

${ }^{3}$ J. Giertych, Hiszpanja bohaterska. Warszawa 1937; R. Fajans, Hiszpania 1936. Z wrażeń korespondenta wojennego, in: M. Szczygieł (ed.), 100/XX. Antologia polskiego reportażu XX wie$k u$, Volume 1, Wołowiec 2014; J. Przewieczerski, Hiszpania w ogniu: reportaż z 22 rycinami, Warszawa 1936.

${ }^{4}$ M. Warneńska, Zwierciadło z Toledo, Warszawa 1985.

${ }^{5}$ M. Kuncewiczowa, Don Kichot i niańki, Lublin 1990.

${ }^{6}$ A. Giddens, Nowoczesność i tożsamość. „Ja" i społeczeństwo w epoce późnej nowoczesności, A. Szulżycka (tr.), Warszawa 2012.

${ }^{7}$ J. Urry, Socjologia mobilności, J. Stawiński (tr.), Warszawa 2009; Z. Bauman, Ponowoczesność jako źródło cierpień, Warszawa 2013.

${ }^{8}$ K. Wolnik-Vera, Przystanek Barcelona, Warszawa 2014; K. Wolnik-Vera, Z. Siewak-Sojka, Costa del Sol i Costa de la Luz, Bielsko-Biała 2018; M. Bernatowicz, Hiszpania. Fiesta dobra na wszystko, Warszawa 2017; M. L. Graff, Spokojnie, to tylko Hiszpania. Przewodnik po różnicach kulturowych, J. Zabrodzka, P. Wciślik (tr.) Warszawa 2007; M. Olechowska, G. Chołopiak, Hiszpania jakiej nie znacie. Kastylia - la Mancha. W krainie błędnych rycerzy i wiatraków, Brzezia Łąka 2013.

${ }^{9}$ M. Hereźniak, Marka narodowa: jak skutecznie budować wizerunek i reputację kraju, Warszawa 2011. 
topic, shared by a certain group of people ${ }^{10}$. Stereotypical perceptions of other nations are part of a given national culture and confirm that an individual sharing them belongs to a given national community. These perceptions are crucial for assessing and positioning groups of others (heterostereotypes), as well as for developing views about one's own national, ethnic, or cultural group (autostereotypes). In Polish non-fiction literature, the image of Spain is built on the basis of a few constant topoi. Canonically, Spain is associated with sunny beaches and love-related thrills, colorful local culture and impressive cultural heritage, as well as captivating history ${ }^{11}$. Among these associations, an important place is occupied by topoi which are fundamental for the European civilizations, that is holy places, willingly described in traveljournals, diaries, essays and reportages of varying cognitive and literary value $^{12}$. It is still strongly believed that Spain is an ecstatic and sensual space, a landscape of extremities and opposites, a Catalan tandem of seny [common sense] and rauxa [sudden determination or action $]^{13}$. A more sophisticated recipient will look in these texts for longing for the preindustrial Spanish landscape, with its civilizational disparity of the world separated from the rest of Europe spiritually and culturally, longing for the colonial grandeur of the empire, longing for interlacing ingredients of the Arabic, Jewish and Christian past, which was so brilliantly recorded in the prose of Norman Lewis ${ }^{14}$ and Cees Nooteboom ${ }^{15}$, available for Poles in translation.

\section{MATERIALS}

After World War II, Spanish readers were gradually getting acquainted with the oeuvre of Polish literature ${ }^{16}$, yet the figure who was the greatest ambassador of

${ }^{10}$ M. Grzesiak-Feldman, Tożsamościowe uwarunkowania posługiwania się stereotypami, Warszawa 2006.

${ }^{11}$ A. K. Majewska, Rok na Majorce, Kraków 2013; A. Sarzyńska, Barszalona, Kraków 2017.

${ }^{12}$ D. Fórmanowicz, Mężczyzna w chwili, gdy zostaje sam, Warszawa 2016; M. Wiernikowska, Oczy czarne, oczy niebieskie. Z drogi do Santiago de Compostela, Warszawa 2013; J. Gać, El Camino, czyli hiszpańskie wędrowanie, Pelplin 2013.

${ }^{13}$ B. Dudko (ed.), Podróże z Kapuścińskim. Opowieści trzynastu tłumaczy, Kraków 2007, p. 124.

${ }^{14}$ N. Lewis, Voices of the Old Sea, London 1984; idem, The Tomb In Seville, London 2003.

${ }^{15}$ C. Nooteboom, Roads to Santiago: A Modern-Day Pilgrimage Through Spain, London 1997.

${ }^{16}$ I. Narębska, P. Sawicki; Panorama histórico de las traducciones de la literatura Polaca publicadas en España de 1939 a 1975. Tesis doctoral. Universidad de Alicante Facultad de Filosofía y Letras Departamento de Traducción e Interpretación, Alicante 2011. 
Polish literature in the Spanish-speaking world was Ryszard Kapuściński, whose works were congenially translated into Spanish and Catalan by, among others, Agata Orzeszek, Jerzy Sławomirski and Ann Rubión ${ }^{17}$. Kapuściński’s work, which functioned as a model for a whole generation of journalists, received wide scientific reflection, and the author himself became a hero of mass imagination owing to the film Jeszcze dzień zycia (Another Day of Life) by Raul de la Fuente and Damian Nenow. The present article refers to Kapuściński's successors. The analytical corpus compiled for the purpose of this study is comprised of three reportage books devoted to Spain which were published in the years 2013-2017. These are: Pył z landrynek. Hiszpańskie fiesty (2013) by Katarzyna Kobylarczyk, Barcelona stolica Polski (2016) by Ewa Wysocka, and Ludzie z Placu Słońca (2017) by Aleksandra Lipczak ${ }^{18}$. Their authors represent the middle (Wysocka was born in 1965) and young generation (Kobylarczyk - 1980; Lipczak - 1981). The Master and his disciples differ not only in gender and generation, but primarily because of their writing styles and the range of the undertaken reportage activities. Although neither of the female authors can be seen as representing the same kind of individuality Master Kapu did, nor are they counted among "the hottest" reportage authors in Poland nowadays, it can be assumed that the presented texts are interesting analytical material due to at least three reasons: 1) they document (although in microscale) the directions of the development of the modern Polish reportage; 2) they show the pragmatics of cultural travel as a cognitive and writing experience of non-fiction authors; 3) they go beyond stereotypical representations of the image of Spain in Polish texts. The repertoire of the selected texts was profiled to show possibly most diverse, alternative, nonstandard perspectives on the issues discussed in the present study. The proposed analytical corpus is arbitrary, it does not exacerbate all possible interpretations of Spanish experiences in the modern non-fiction literature and has been embraced only for the purpose of this study.

${ }^{17}$ H. Stochniałek, En busca de las normas de traducción: la prosa polaca traducida en España y en México: estudio del caso, rozprawa doktorska, Uniwersytet Warszawski 2005, Saarbrücken 2012.

${ }^{18}$ K. Kobylarczyk, Pył z landrynek. Hiszpańskie fiesty, Wołowiec 2013; A. Lipczak, Ludzie z Placu Słońca, Warszawa 2017; E. Wysocka, Barcelona stolica Polski, Warszawa 2016. 


\section{METHODS}

The character of the undertaken study is interdisciplinary. From the perspective of media sciences, its methodological basis consists in qualitative research, especially content analysis, understood as "all systematic procedures whose aim is to examine the content of reported information"19. The applied methods will also include literary and historical studies methodology, which will make it possible to describe the morphology of text, yet also provide a chance of referring to extratextual senses, such as historical, social and cultural contexts ${ }^{20}$. This will be especially fruitful when it comes to the issue of memory. The 20th century is a period of a fight for memory, a period when memory discourse flourished, when history of the second degree triumphed, i.e. the remembered history dominated over the event history ${ }^{21}$; it is also a period of distrust towards grand narratives and a period of openness to microhistory ${ }^{22}$. New memorization projects were concluded with original narrative concepts, a greater status of diaries, autobiographies and reportages. It is visible that all this was really sense-generating when one invokes reportages of Svetlana Alexievich - a Nobel Prize laureate (2015) in literature, which she received for a reportage. The end of the 20th century, in line with reorientation of the geopolitical map of Central Europe, triggered a chain of undertakings oriented towards recording collective identities of communities with a new matrix of memory. In the Polish reality, it became rudimentary to develop a language to write about expulsion of Germans from areas taken over by Poland in 1945, about the Holocaust of Polish Jews, about moral and ideological heritage of communism. In the Iberian Peninsula, communicative memory (functioning within one generation) and cultural memory (across generations,

${ }^{19}$ R. D. Wimmer, J. R. Dominick, Mass media. Metody badań. T. Korłowicz (tr.), Kraków 2008, p. 211.

${ }^{20}$ A. Kaliszewski, E. Żyrek-Horodyska, Kilka uwag o metodach analizy tekstów dziennikarskich ze szczególnym uwzględnieniem reportażu, in: A. Szymańska, M. Szymańska-Magdziarz, A. Hess, (ed.), Metody badań medioznawczych i ich zastosowanie, Kraków 2018, p. 116.

${ }^{21}$ P. Nora, Les lieux de memoire, Paris 1997.

${ }^{22}$ A. Assmann, Cultural memory and western civilization: functions, media, archives, Cambridge 2011; P. Ricoeur, Pamięć, historia, zapomnienie, J. Margański (tr.), Kraków 2006; R. Traba, Historia - przestrzeń dialogu, Warszawa 2006; E. Domańska, Mikrohistorie - spotkania w międzyświatach, Poznań 2005. 
exceeding the horizon of experience, recorded in texts, places, figures and myths) struggled with, among others, challenges of the colonial past and fresh heritage of enslavement.

The presented reflection will take into consideration the methodology of cultural tourism - a young discipline situated in the field of social and economic sciences, humanities and Earth science ${ }^{23}$. The subject of research in cultural tourism comprises travelling to objects and places of culture as well as participating in cultural events (high and popular culture), thanks to which people who travel encounter products of culture. This leads to broadening their knowledge about the world of man, and the presence of culture-related content is decisive when it comes to them deciding to participate in this form of travelling ${ }^{24}$. Today, no one questions the conclusion that the tourist experience has become egalitarian and trivialized ${ }^{25}$. Postmodernity transformed otherness and mystery into tourist attractiveness of a given place, it changed "the landscape of initiation not even into a kind of thematic park, but into a space of sensation, dominated by sensual experience"26. Tourist industry keeps generating new areas of expansion. Great capital has been invested in cultural heritage, religious ethnic, event, Erasmus and volunteer tourism, as well as alternative and extreme tourism ${ }^{27}$. Postmodernist tourists have at their disposal modern distribution channels and useful gadgets: geo-guidebooks and audiovisualisations, interactive maps, QR codes, holograms, applications, social media services, WWW pages, blogs $^{28}$ as well as interactive outdoorgames, such asquesting, geocaching, and orienteering ${ }^{29}$. New destinations, experiences, narratives and their heroes are being born as we speak ${ }^{30}$.

${ }^{23}$ A. Mikos von Rohrscheidt, Turystyka kulturowa. Fenomen, potencjał, perspektywy, Poznań 2010.

${ }^{24}$ Ibid.

${ }^{25}$ D. MacCanell, Tourist: a new theory of the leisure class, New York 1989.

${ }^{26}$ K. Łukasiewicz Krzysztof, I. Topp, Przewodniki w kulturze i kultura jako przewodnik, „Prace Kulturoznawcze” nr 17 (2015), p. 10.

${ }^{27}$ K. Buczkowska, Turystyka kulturowa. Przewodnik metodyczny, Poznań 2008.

${ }^{28}$ A. Stasiak, B. Włodarczyk, J. Śledzińska, Wczoraj, dziś i jutro krajoznawstwa, in: A. Stasiak, B. Włodarczyk, J. Śledzińska (ed.), Współczesne oblicze krajoznawstwa, Warszawa 2016; M. Jerczyńska, Gospodarka elektroniczna w sektorze turystyki, „Logistyka” nr 2 (2006), p. 65-66.

${ }^{29}$ M. Zamelska, B. Kaczor, Interaktywne formy współczesnego krajoznawstwa na przykładzie Wielkopolski, in: A. Stasiak, B. Włodarczyk, J. Śledzińska (ed.), Współczesne oblicze krajoznawstwa, Warszawa 2016, p. 315-328.

${ }^{30}$ B. Kita, Między przestrzeniami. O kulturze nowych mediów, Kraków 2003. 
Baedekers and reportages are attractive analytical materials for those who investigate cultural tourism. These genres developed their modern formula as late as the 20th century, yet their sources expressing the imperative of travelling go back to the Greek perégiesis and the Roman itinerarium ${ }^{31}$, medieval peregrinations and merchants' accounts, renaissance reports of diplomats and scientists, and soon also diaries of those travelling to new lands ${ }^{32}$, grand toursand reports of peregrinations of Romantics ${ }^{33}$. A classical Baedeker is focused on presenting a particular geographical-cultural location, portraying the world selectively (when it comes to topics, objects, events, routes, maps). It gives tips as to how to recognize the space around, it inscribes the present into the cultural heritage (creating a cultural landscape). Moreover, it writes scripts telling tourists how to experience the reality, while when it comes to communication strategies, it imitates a situation of "a shared walk"34.

Linguists and media researchers unanimously claim that breaking the monopoly of verbal culture by the multimedia came as a conclusion to attempts at producing a linguistic definition of text, which proved unsuccessful. Genealogical reflection is what should follow the consequences of the communicative arena transformation as well as texts which employ various media and semiotic systems. Written in a new communicative reality, reportage attempts at meeting new challenges. Already Kapuściński, looking for new epistemological perspectives, experimented with essay, collage, poetry, photography, as well as exploring potentials of anthropological narration, and sharing his views as an expert ${ }^{35}$. Kapuściński's writing inspired the genre of reportage when it comes to cognitive achievements of Annales School (promoting "soft" facts) and The New Journalism School (essayization and anthropologization of narration, fascination with magical journalism). Today, non-fiction prose is more and more often treated

${ }^{31}$ J. Sznayder, Podróże w starożytności, Warszawa 1959.

${ }^{32}$ A. Mączak, Peregrynacje. Wojaże. Turystyka, Warszawa 1984; H. Dziechcińska, O staropolskich dziennikach podróży, Warszawa 1991.

${ }^{33}$ J. Kamionka-Straszakowa, Zbłąkany wędrowiec. Z dziejów romantycznej topiki, Wrocław 1992.

${ }^{34}$ Z. Rybczyńska, Potęga i niemoc spojrzenia Meduzy: alternatywne przewodniki miejskie jako realizacja nowej utopii, „Prace Kulturoznawcze” nr XVII (2015), p. 129-141.

${ }^{35}$ A. Kunce, Antropologia punktów. Katowice 2008; A. Kamińska, Europejczyk w podróży: odmienność i tożsamość jako kategorie opisu świata w reportażowej twórczości Ryszarda Kapuścińskiego, Białystok 2017. 
as a form of textualizing experience equal to fiction ${ }^{36}$. Academic studies propose resigning from the genealogical perspective, and shifting interests towards analyzing thematic blocks independently of generic their provenience. Reportage is more openly claimed to be a certain communicative license, a multimedia genre. Krzysztof Stępnik ${ }^{37}$ writes about silvic perspectives on reportage; Edward Balcer$\operatorname{zan}^{38}$ proposes a systematics of quasi-generic paradigms; Tomasz Goban-Klas ${ }^{39}$ and Paweł Zajas ${ }^{40}$ claim that the juxtaposition of fiction vs. non-fiction is not true. In 2010, serious debates on journalists' ethics were inspired by a book of Artur Domosławski, which was interpreted as an attack on the authority of Master Kapuściński, or alternatively as a Promethean gesture of freeing oneself from the debate on writer's workshop ${ }^{41}$.

\section{ANALYSIS}

\section{Challenges of modernization, or what we learn from Spanish experience: Aleksandra Lipczak}

Aleksandra Lipczak's reportage narration has been influenced by the greatest. The author fell in love with Spain because of Vengo, a film by Tony Gatlif. She collected her material thanks to a scholarship awarded by Ryszard Kapuściński Herodot Foundation, and she prepared the text inspired by Mariusz Szczygieł, one of the best Polish reporters of the middle generation. As a result, her work was shortlisted for Witold Gombrowicz Award. Publishing in the most important Polish opinion weeklies and having lived in Spain for six years, Lipczak says:

${ }^{36}$ G. Grochowski, Pytania o niefikcjonalna prozę dyskursywną, in: M. Czermińska (ed.), Polonistyka w przebudowie, Kraków 2005, p. 650-665.

${ }^{37}$ K. Stępnik, Dekonstrukcja reportażu. (Zygmunta Nowakowskiego „Niemcy a la minute..."), in: M. Woźniakiewicz-Dziadosz (ed.), Fabularność i dekonstrukcja, Lublin 1998, p. $165-166$.

${ }^{38}$ E. Balcerzan, W stronę genologii multimedialnej, in: W. Bolecki, I. Opacki (ed.), Genologia dzisiaj, Warszawa 2000, p. 97.

${ }^{39}$ T. Goban-Klas, Świat Ryszarda Kapuścińskiego, in: K. Wolny-Zmorzyński, W. Furman, J. Snopek (ed.), Mistrzowie literatury czy dziennikarstwa?, Warszawa 2011, p. 120.

${ }^{40} \mathrm{~K}$. Zajas, Zagubieni kosmonauci. Raz jeszcze o "Imperium" Ryszarda Kapuścińskiego i jego krytykach, „Teksty Drugie” nr 3 (2010), p. 218-231.

${ }^{41}$ G. Wołowiec, O Domosławskim i jego krytykach, „Teksty Drugie” nr 1-2 (2011), p. 279-288. 
Spain which I got to know was the most fashionable and the sexiest country in Europe. It was rushing ahead, imposing trends. I got to know it like that, and I got to know it from a completely different perspective in 2008, when everything started collapsing there (...). All sorts of overlooked issues started coming to the surface, all things not dealt with previously, all the matters that had been slighted before, when the country had been stunned by its progress. Now, all these things were impossible to ignore. When I started writing my book, I treated Spain like an older sister of Poland, somehow battered by life, whose mistakes offered some reflection for $\mathrm{us}^{42}$.

Aleksandra Lipczak shares the opinions of her masters, Ryszard Kapuściński and Artur Domosławski, who perceived the reality of the Spanish-speaking Latin America as "laboratories of a new century," where phenomena important for the world had been born ${ }^{43}$. Lipczak inscribes this relation into the Polish context. Ludzie z Placu Słońca is a memento of sorts for the country at the Vistula River, and even more than that - a seismograph of social, economic, and cultural transformations in the 21st-century Europe. This would be a certain variation on the metaphor of "a mirror from Toledo" established by Monika Warneńska (1985) in her reportage book focused on memories. Forgotten today, this book encompasses a collection of ideological falsehoods disseminated in Poland after the Yalta Conference about the Spanish civil war and related to the dogmatization of the image of the Spanish confrontation with Fascism ${ }^{44}$. Diachronically read, nonfiction texts show how unstable the interpretation line of these experiences is. Warneńska, a journalist related to the socialist authorities, assesses the Solidarity surge of August 1980 very negatively. Supporting the oppressive gesture of General Wojciech Jaruzelski, who introduced the Martial Law on 13 December 1981, she saw the budding democratic movement in Poland as a shadow of Spanish Falange and a fifth column, "which served foreign empires, foreign interests, and was the bane of the country" 45 . A totally different image is shown in the Spanish "mirror" of the reporters of the younger generation. Lipczak, and Wysocka, who

${ }^{42}$ Wierzę w empatycznq Hiszpanię. With A. Lipczak talking M. Majewska, „Krytyka Polityczna”, 23.09.2017, https://krytykapolityczna.pl/swiat/aleksandra-lipczak-hiszpania-reportazwywiad/ (access: 01.03.2020).

${ }^{43}$ W. Bereś, K. Burnetko (ed.), Nie ogarniam świata: z Ryszardem Kapuścińskim, Warszawa 2007.

${ }^{44}$ J. Kieniewicz, Hiszpania w zwierciadle polskim, Gdańsk 2001.

${ }^{45}$ M. Warneńska, op. cit., p. 333. 
will be mentioned later - declaring their faith in human freedom and democracy focused on a different symmetry in the histories of Poland and Spain, that is oppressiveness of a regime violating rights of an individual. With her social and political temper, Lipczak, who specializes in the theme of migration, watches Spain of the transformation in the first decade of the 21st century. Analogies between Polish and Spanish experience which interest her appear at the political level (the authoritarian past, transformation drawing "a thick line" to cut off the past, "coming back to Europe" concept), mental and axiological level (Catholicism), as well as economic level (the crisis of the beginning of the 21st century).

"A Spanish fad" is what Lipczak calls her book ${ }^{46}$, having in mind its stylistic polymorphism. Reportage hybrids sketched with the technique of patchwork express the Spanish aesthetics and are adequate to the way problems are formulated in the text. Each of the reportages collected in the volume shows a different technique of working with facts and the text itself. The traditional first-person narrative is complemented with objectified historical sketches, forms of investigative journalism, meticulously structured collages, reportage portraits, and interviews. Agnieszka Warnke compared the nuances of generic variations of Lipczak's reportages to Spanish dances.

The collection includes reportages whose voice reminds one of flamenco. Although it does not tell a story, body movements and gestures express emotions. They show a special magnetizing energy. The same sensitivity, passion, depth and rhythm is there in Ludzie z Placu Stońca. For instance, a story about looking for the signs of the dead who "disappeared" during the war is like soleá - brimming with melancholy, materializing loneliness and pain of losing a loved one. It requires focus, although the slow pace sometimes quickens. In turn, alegrías means joy, beauty of human relationships, and such a positive ambience describes "Zwyczajna wieś" [An Ordinary Village].A bitter-sweet answer to the question "Co można zrobić (z) Franco w dwudziestym pierwszym wieku?" [What can be done with/to Franco in the 21st century?] is exuberant, just like bulerías, which must be danced at every fiesta $^{47}$.

${ }^{46}$ Historia, reportaż. With A. Lipczak talking M. Wilk, \#rozmowyliczanki [ep. 38], 18.12.2017, https://www.youtube.com/results?search_query=lipczak+rozmowyliczanki (access: 12.03 .2020$)$.

${ }^{47}$ A. Warnke, Aleksandra Lipczak, Ludzie z Placu Słońca, 20.05.2017, https://culture.pl/ $\mathrm{pl} /$ dzielo/aleksandra-lipczak-ludzie-z-placu-slonca, (access: 09.03.2020). 
Comparing Lipczak's book to a reportage volume which gained acclaim in Poland some time ago, namely Samotność Portugalczyka [Loneliness of a Portuguese $]^{48}$, it needs emphasizing that her way of presenting the story is more capricious and associative. What is common for both narratives is a truly emphatic portrayal of longing for the imperial past. Struggling with postcolonial qualms, confronted with the challenges of globalizing societies and visions of a still increasing wave of immigration, works as a pretext to sketch a collective portrait of the presented communities, with the spotlight on depicting their emotions, passions and spirit.

Lipczak's quasi guidebook is rebellious in its nature. It leads off the beaten track, into places which are not obvious. The meandering narration may lead the reader astray. That is why it was necessary to introduce sections to make particular parts cohesive and organized, to build hierarchy and chronology of the presented episodes. Working as preludes, interjections and punchlines, they are often commentaries - grotesque, ironic, dramatic. In its compositional aspect, Ludzie z Placu Słońca reminds one of Mariusz Szczygieł's reportage technique. Lipczak is aware of her material, she plays an intelligent game with the reader, betraying the conventionality of the creative act. There is not one Spain and there is not one narration, which is impressively documented with a compositionally interesting reportage titled "Populacja tygrysa bengalskiego" [Population of the Bengal Tiger], which is based on the magic of numbers. Defining the aims of her book, Lipczak references the formula of reportage guidebook. "I wanted to make it a reportage guidebook to modern Spain, a book which would allow the reader to understand and get to know it at least a bit. This is a book which replaces folklore with stories about a country made of flesh and blood"49. The formula of Baedeker will come to the surface also as an element of the intertextual layer of the text, among others, in quotations from a guidebook prepared by Barcelona en Comú.

${ }^{48}$ I. Klementowska, Samotność Portugalczyka, Wołowiec 2014.

${ }^{49}$ W Hiszpanii wszystko jest bardziej. With A. Lipczak talking M. Bojanowska, K. Chojnacka, „Nowy Folder” 03.05.2017, http://nowyfolder.com/aleksandra-lipczak-w-hiszpaniiwszystko-jest-bardziej/ (access: 11.03.2020). 
Lipczak avoided image stereotypes of a sunny country. There is no Sun, Sand, Sea landschaft, there are no sweaty tourists in Park Güell, crowded beaches and fashionable restaurants. There are no aesthetics of exaggeration as if taken out of Pedro Almodovar's films, gloomy air of Carlos Saura's films, or metaphysics, which has been inscribed into Ibero-American literature. Lipczak made the image more complex, introducing, among others, the context of "European Orient," a laboratory of European migrant experiences, unresolved traumas from the European past, the effectiveness of antiestablishment movements, debates on the role of gender. These elements of the cognitive layer should be seen as valuable: they universalize the message of the reportage and inscribe the text into the European context.

The texts of Spanish culture come to life in the ways of imaging, comparing and introducing metaphors. Neo-ruins - poignant mementos of pre-crisis aggrandizement - remind the author of surrealist projects of Salvador Dali and Luis Bunuel. Don Quixote appears in order to fight modern specters of "cities with no people, roads with no cars, zebra crossings with no pedestrians, airports with no passengers"50. The language of stylistic excess or dry report, the mannerism of enumeration, and street art rhetoric all express the aberration potential of places and spaces during an economic crisis, demonstrating how art becomes part of the social climate of the 21st-century Spain. For the purpose of her reportage, Lipczak skillfully adapts the language of the street, media slogans, whispers of family secrets and expert jargon, powerful authenticity of newspaper adds, intimacy of prayer-like letters of intent, rhetoric of soulless official letters. She compiles them into a flexible material to express the Spanish experience.

${ }^{50}$ A. Lipczak, Ludzie..., op. cit, p. 29. 
For Tim Ederson ${ }^{51}$, tourism is a performative act - creating and recreating meanings and values. Such an understanding can be applied to a reportage experience: participating in an incident and creating a textual fact. The variety of sources to be found in the concluding section of the book is truly impressive. Lipczak absorbs the atmosphere of a huge crowd of a street demonstration, listens to confessional narratives of people affected by the crisis, debates with visitors of the mausoleum in the Valley of the Fallen, reads art present in the public space, in Melilla looks at the life at the southern border of Europe, talks to anthropologists exhuming the remains from the period of the civil war, undoubtedly having in mind analogous images from the Bosnian reportage book by Wojciech Tochman (Jakbyś kamień jadła) or his recent publication devoted to Cambodia (Pianie kogutów, płacz psów) ${ }^{52}$.

Three modules contribute to the cognitive structure of Aleksandra Lipczak's volume. These are:

\section{Modernizing and emancipatory discourse}

Modernizing and emancipatory discourse reports transformations of the traditionally patriarchal Spanish society and relationships of the genders. The author describes the way which Spanish society travelled from machismo to the time when feminist, LGBT+ and transgression movements came into the picture of public narration in the 1980s. She looked for the senses of ideological revolution initiated by Josè Luis Rodriguez Zapatero at the emancipated streets of Madrid, provocations of Almodovar's avantgarde films and in the silence of provincial Spain, where people of the same gender can get married. On the margins of debates concerning sexuality, a treaty on plurality, freedom and human rights was built. "Not sex, but indeed democracy. Not orientation, but participation"53 - she writes. The author created fascinating portraits of strong and charismatic women: Pilar Primo de Rivera, and Ada Colau. These portrait reportages, which can be compared to the best models of world reportage, are at the same time huge frescos documenting the social-cultural and political background, boldly reaching

${ }^{51}$ T. Edensor, Performing tourism, staging tourism: (re)producing tourist space and practice, „Tourist Studies” nr 1 (2001), p. 59-81.

${ }^{52}$ E. Tochman, Jakbyś kamień jadła, Wołowiec 2002; idem, Pianie kogutów, płacz psów, Wołowiec 2019.

${ }^{53}$ A. Lipczak, Ludzie..., op. cit., p. 134. 
for tools of sociological, psychological and cultural analysis. If one assumes, as Jacques Lacan $\operatorname{did}^{54}$, that language which we inherited is masculine and expresses the structure of patriarchy, Lipczak's prose is herstory, a contrnarrative when compared with the androcentric perspective.

\section{Civic discourse}

The subject of civic discourse in Lipczak's narration concerns the habitus of precarians and stateless people, whom the author watches in Barceloneta and Melilla. These are the figures of "people-rubbish", "people-waste", unwanted products of globalization ${ }^{55}$. Their isolation at the margins (in refugee camps), the ambivalent status of their subjugation to the law, and at the same time excluding them from the law, make them model icons of homo sacer ${ }^{56}$. Lipczak's social, activist temper tells her to watch admiringly how the civic public space of cities affected by recession is being built and how a neoliberal model of city space is being experimented with in Barcelona. She is fascinated with the phenomenon of antisystem civic ventures as a reaction to compromised rhetoric of consumption (Plataforma de Afectados por la Hipoteca (PAH) [Platform for People Affected by Mortgages]). What deserves special attention is a dynamically sketched portrayal of a Barcelonian district El Raval, together with its unique geography, aesthetics and ethics, morality and customs, linguistic polymorphism, multiculturalism, original portraits of its citizens, and in a wider perspective - frescoes on politics of exclusion and otherness. The chronicler's diligence makes it necessary to mention that an equally warm and friendly portraits of this Barcelonian district can be found in fiction narration of Aga Sarzyńska's novel ${ }^{57}$.

These sections of the volume constitute a cognitively important contribution concerning the heritage of the colonial past of Europe and globalization challenges of the post-migration world, which still does not know if its policy is more that of walls or bridges. Migrant reality of Frontera Sur is a world woven from the relief beauty of Arab aesthetics and the dirt pushed out of the continent.

${ }^{54}$ J. Lacan, Funkcja i pole mówienia i mowy w psychoanalizie, B. Gorczyca, W. Grajewski (tr.), Warszawa 1995.

${ }^{55}$ Z. Bauman, Życie na przemiat, Kraków 2006.

${ }^{56}$ G. Agamben, Homo sacer, Stansford 1998.

${ }^{57}$ Raval, dzielnica Barcelony, to była miłość od pierwszego wejrzenia. With A. Sarzyńska talking Michał Nogaś „Duży Format” nr 29 (2017), p. 23-24. 
Here, Franco's monuments have not been pulled down and people live with their colonial memories. Migrants who are fended off with barbed wire from Europe come here willingly. This reportage does not have such a powerful drama potential as the panoramic Amexica. War along the Borderline by Ed Vulliamy, a British reporter of The Guardian, yet we can find here a clear correspondence to the humanitarian tone of the diagnosis present in European reportages ${ }^{58}$. Lipczak published a number of reportages, articles and interviews on the topic of migrants and refugees, and here she touches upon problems which have been addressed by political scientists, sociologists, and culture researchers. In reportage details she describes a transition from "Europe of the world" to "Europe in the world"59, in microscale diagnosing "the strange death of Europe" 60 and the phenomenon of open society which is being born in pain.

\section{Memorization discourse}

Memorization discourse of Lipczak's book is oriented towards telling a story about the Spanish transition from dictatorship to freedom. "Co można zrobić (z) Franco w dwudziestym pierwszym wieku?" [What can be done with/to Franco in the 21st century?] is one of the titles in the book ${ }^{61}$. Memory is a collective phenomenon $^{62}$; it is construed, passed down and shared socially. It is a focus of tradition, a tool integrating a community, legitimizing the authorities and order, creating bonds and group identities. Reportage prose of the presented authors appreciates the significance of cultural memory recorded in texts, architecture, educational institutions, museums and monuments, customs (which are all media of memory). The repertoire of memory practices present in the book encompasses, among others, rituals and family stories, studies of historical topography, participation in celebrations of local and state festivals.

${ }^{58}$ W. Bauer, Über das Meer: mit Syrern auf der Flucht nach Europa, Berlin 2015; K. Brinkbäumer, Traum vom Leben: eine afrikanische Odyssee, Frankfurt a. M. 2011; S. Liberti, A sud di Lampedusa: cinque anni di viaggi sulle rotte dei migranti, Roma 2011; P. Kinsley, New Odyssey: the story of the twenty-first-century Europe's refugee crisis, New York 2016.

${ }^{59}$ W. Bereś, K. Burnetko, op. cit., p. 164.

${ }^{60}$ D. Murray, Strange death of Europe: immigration, identity, islam, London 2017.

${ }^{61}$ A. Lipczak, Ludzie..., op. cit., p. 163.

${ }^{62}$ M. Halbwachs, Społeczne ramy pamięci, M. Król (tr.), Warszawa 2008. 
Described in reportage style, these phenomena can be addressed with tools developed by memory studies. It is especially useful to employ the categories of cultural and communicative memory ${ }^{63}$, functional and storage memory ${ }^{64}$ and the theory of places of memory - les lieux de mémoire ${ }^{65}$. In this sense, Lipczak's reportages are narratives about the culture of memory understood as the presence of the past in public space, e.g. in art, museum exhibits, language, official and confessional narratives. Memory is a process of remembering (Erinnerung), yet also denying and forgetting. Erich Maria Remarque in The Night in Lisbon wrote about dynamics of memory, which reminds one of an animal devouring its own body in order to still exist ${ }^{66}$. Lipczak describes how Spaniards do not remember, marginalize, and taboo. Modulation of memory in society - which is recorded in Lipczak's reportages - results from various changes: social-cultural (e.g. generational), political and institutional. Understood this way, memory of the civil war and Francoist regime is nolens volens the central point describing the Spanish memorizing experience of the 20th century. "Franco is still in our heads. Ever alive, always fresh. A skeleton in the closet. A dictator in the fridge. Not buried, only cast aside" ${ }^{\prime 67}$. Lipczak's narratives convince us that the present is uncertain in the face of acknowledging and settling the past. American historian Timothy Snyder wrote about the power of the "fourth dimension": "a sense of the future has to be created in the present from what we know of the past, the fourth dimension built out from the three of daily life" 68 .

Lipczak's prose tells a story about the birth of a social need for narration about the past and renegotiating memory. The author agrees with Kapuściński, who believed that modernity was a triumph of institutionalized memory, effectively stifling private narratives ${ }^{69}$. Yet these are private narratives that are most significant for a reporter. Lipczak writes about the silence of school handbooks

${ }^{63} \mathrm{~J}$. Assmann, Cultural memory and early civilization: writing, remembrance, and political imagination, Cambridge 2011.

${ }^{64}$ A. Assmann, Cultural memory and western civilization: functions, media, archives, Cambridge 2011.

${ }^{65}$ P. Nora, Les lieux de memoire, Paris 1997.

${ }^{66}$ E. M., Remarque, Noc w Lizbonie, R. Wojnakowski (tr.), Warszawa 2015, p. 125-126.

${ }^{67}$ A. Lipczak, Ludzie..., op. cit., p. 139.

${ }^{68}$ T. Snyder Timothy, Black Earth: the Holocaust as History and Warning, eBook 2015, p. 343.

${ }^{69}$ W. Bereś, K. Burnetko, op. cit., p. 18. 
and encyclopaedias, about the burden of fear (there is a poignant reportage about a man who did not leave his home in fear of the dictatorship); records the difficult process of unblocking memory of witnesses (a reportage about looking for the graves of "disappeared" people (desaparecido) from the time of the civil war), she also writes about diversification of ideas about places of memory. These sections of the volume are very interesting for the Polish reader as they point to some correspondence to Polish memorization experience of the 20th century ${ }^{70}$. Polish white spots on the map of the national memory - still controversial and deformedly conceptualized - refer, for instance, to witnessing the holocaust of Polish Jews during German occupation, moral responsibility for being engaged in the communist system, for victims of Stalinist repressions and the Martial Law of 1981. "To Europe, but with your sloppily buried dead"71, the author writes, paraphrasing the tile of Maria Janion's book (Do Europy tak, ale z naszymi umarłymi [To Europe, but with our dead], 2017). The Polish literary scholar wrote a book about the consequences of the end of Romantic-symbolic culture and about changes in perceiving and remembering the cultural heritage of the past - also the most gloomy, shameful and evil past (with reflection on antisemitism as a main motif). Referring to Janion, Lipczak proposes a group therapy to Spaniards. Working through the past - bidding a dignified farewell to the ancestors and carefully listening to their heritage - is a condition that must be fulfilled in order to determine ethical perspectives of the future.

Aleksandra Lipczak looks underneath "the lining of the world"72. Under the layer of Baedeker rhetoric made up to cater to tourists who consume Spain, she found a picture of a European country abundant in dramas and mysteries, intriguing narratives and unique characters. She described a country facing its past, yet boldly creating the vision of its future. It is a pity that the author so sparingly used the literary style when it comes to language, portrayal of the characters and compositional plan. Her journalistic temper effectively stifled her literary predilections.

${ }^{70}$ L. Nijakowski, Polska polityka pamięci. Esej socjologiczny, Warszawa 2008.

${ }^{71}$ A. Lipczak, Ludzie..., op. cit., p. 161.

72 J. Alvaro J., Ksiq̨żka Ludzie z Placu Słońca. Recenzja i wywiad z autorkq, 2017, https:// hispanico.pl/ksiazka-ludzie-z-placu-slonca/ (access: 09.03.2020). 


\section{Off the beaten track of the present, that is a guide to event culture: Katarzyna Kobylarczyk}

While Aleksandra Lipczak admired Spanish modernizing undertakings, Katarzyna Kobylarczyk asked about the meaning of cultural heritage of local communities. Lipczak rationally analyzed facts, Kobylarczyk collected impressions and emotions, juxtaposed the logic of facts with the non-physical, non-literal. She opened up to the invisible, non-obvious, spiritual. Lipczak's texts are reportages focused on problems which very rarely reached out for the literary style. Kobylarczyk created reportages-essays, reportages-impressions, reportages-miniatures written with sensual language and elaborative metaphors. The style of her narratives reminds one of elegant and erudite phrases of travel essays of Maria Kuncewiczowa (1990), already mentioned above. The latter's grand tour was reminiscent of the best patterns of the literature of the previous century. It was compiled from reportage detail, nuggets recorded in memory, emotions pursuant to experiencing great texts of culture, written with the awareness of metaphorical senses. "Everything a foreigner's eyes see casts a shadow, grows into a metaphor, while the sense of things and events flees like a scent"73 - this is what Kuncewiczowa said and what Kobylarczyk could repeat. The author created a beautiful narrative, pervaded with internal rhythms and tensions, once closer to the boredom of a walk in heavy heat, once dynamic like a telegram.

Pył z landrynek originated from a blog (http://septimo-piso.blogspot.com), yet texts it comprises are not mere reprints. The first-person figure of the narrator is shaped on the basis of a habitus of a journalist correspondent who embraces a duty to penetrate various spheres of reality and relate facts to the reader. "Your correspondent" - this is how, suspiciously seriously, the narrator calls themselves, describing preparations to the journey as if they were readying themselves to participate in a dangerous war mission (equipment, research, planning). Obviously, this is an intellectual joke, an intelligent parody of the ethos of war journalist, who is today focused not on information but rather on live coverage $\mathrm{e}^{74}$.

Kobylarczyk's undertaking is ambitious in its conceptual layer: it is a subjective description of the most fascinating Spanish fiestas. Although it is not

${ }^{73}$ M. Kuncewiczowa, op. cit., p. 123.

${ }^{74}$ D. Matheson; S. Allan, Digital war reporting, Oxford 2013. 
a precedent in the Polish 21st-century reportage ${ }^{75}$, this undertaking is especially great in its scope and rich in sources. The book remains underappreciated. It was accused of being kaleidoscopic and superficial, written in exalted language ${ }^{76}$ and limited to passive observation of cultural phenomena.

Kobylarczyk's journey is part of an infectious trance resulting from getting excited with the show and participation. This is an attempt of documenting various Spanish fiestas and watching people who, on the one hand, celebrate a festival as an element of the old tradition; on the other hand, noticing progressing commercialization and gradual transformation of street celebrations into mindlessly ticked tourist attraction ${ }^{77}$.

Very rarely was the author praised for her erudition, thorough subject-matter preparation, colorful language ${ }^{78}$. Only one review emphasized what actually is the greatest asset of the volume: looking for metaphysics in the secularized world.

For Katarzyna Kobylarczyk, a Spanish fiesta is one of a kind anthropological and historical phenomenon, connecting generation after generation in an unbreakable chain of culturally-rich tradition. It has different faces, being an indispensable element of the identity of citizens of particular villages, cities and regions. Everyone, independently of being a native or a tourist passing by, can read in the fiesta one common message: stop and celebrate. Do not rush. Time is not going to run out ${ }^{79}$.

Mircea Eliade believed that being exposed to sacrum and myth is fundamental human experience thanks to which man gets acquainted with non-historical sacral reality and escapes the power of $\operatorname{chaos}^{80}$. Sacrum builds the sense of the

${ }^{75}$ M. Bernatowicz, Hiszpania. Fiesta dobra na wszystko, Warszawa 2017; M. L. Graff, Spokojnie, to tylko Hiszpania. Przewodnik po różnicach kulturowych, J. Zabrodzka, P. Wciślik (tr.), Warszawa 2007.

${ }^{76}$ J. Marchwica, Recenzja Pył z landrynek, 2017, http://etnosystem.pl/ksiazka/recenzje/7194-kobylarczyk-pyl-z-landrynek (access: 10.03.2020).

${ }^{77}$ B. Darska, Recenzja Pył z landrynek. Hiszpańskie fiesty, 2017, https://kultura.onet.pl/ recenzje/recenzja-pyl-z-landrynek-hiszpanskie-fiesty-katarzyna-kobylarczyk/sgzn0f8 (access: 02.03.2020).

${ }^{78}$ Morgause, Pył z landrynek. Hiszpańskie fiesty, 2015, https://www.biblionetka.pl/art. aspx?id=939259 (access: 07.03.2020).

${ }^{79}$ J. Kapica-Curzyste, Fiesta forever, 2013, https://esensja.pl/ksiazka/recenzje/tekst. html?id=16522) (access: 05.02.2020).

${ }^{80} \mathrm{M}$. Eliade, The quest: history and meaning in religion, Chicago 1971. 
world, allows one to recognize values, organizes space and time. Fiestas constitute the time of sacrum as an interval of daily life. They materialize mythical events which worked "at the beginning," with their cyclic nature document the lasting existence of the world. In the modern laicized times, sacrum does not have to have a religious context, it may denote a ritual which centers around itself a particular community, stopping the reality. Fiesta is nowadays a field of interdisciplinary research within social and humanist studies. An anthropological analysis of fiestas' ontology shows that through cyclic updating of particular rituals and ceremonies, it is an important manifestation of local identity and cultural distinctiveness of a given community ${ }^{81}$. Its meaning is historical, cultural, religious, folklore and social. It constitutes a microcosmos with its own language, aesthetics, hierarchy, and axionormative system.

It is this functional multifaceted nature of fiestas, the complicated nature of social rituals and behaviors and manifestations of sacrum that interests Katarzyna Kobylarczyk. The author complements her reportage participatory observation with thorough knowledge on history, anthropology, ethnography. As a result, she creates engaging minitreatise about patrons of festivals, local heroes and myths, about intermingling of modern religious practices and pagan rituals. Kobylarczyk asks about the position of fiestas in the times of posttourism and in relation to the paradigm of entertainment, emotion, education, engage ${ }^{82}$. She realizes that the watched spectacles have been commercialized, she knows how ambivalent the impact of tourist industry on local communities is. In her attitude towards the world there is no naivety of "postmodern tourists," who look for "authenticity"83. Yet Kobylarczyk's narrative confirms that event tourism has not destroyed the authentic character of Spanish fiestas ${ }^{84}$.

${ }^{81}$ S. R. Becerra, Religión y fiesta. Antropología de las creencias y rituales de Andalucía, Sevilla 2000 .

${ }^{82}$ A. Wieczorkiewicz, Apetyt turysty. O doświadczaniu świata w podróży, Kraków 2008, p. 235.

${ }^{83}$ D. MacCanell, Tourist: a new theory of the leisure class, New York 1989.

${ }^{84}$ E. Malchrowicz-Mośko, K. Buczkowska, Fiesty hiszpańskie - jeszcze święta lokalne, czy już tylko atrakcje dla turystów?, „Turystyka Kulturowa” 2010 / 4, p. 17-37; K. Buczkowska, E. Malchrowicz, Współczesne znaczenie hiszpańskich fiest religijnych w opinii młodych polskich turystów i mieszkańców Hiszpanii, „Szczecińskie Zeszyty Naukowe. Turystyka religijna zagadnienia interdyscyplinarne" nr 647 (2011), p. 111-125. 
Katarzyna Kobylarczyk's event guidebook is deceitful. Again, we deal here with a genre alteration, with staffage. Pył z landrynek is a metaguidebook. A guidebook offers a readable and reasonable itinerary, Kobylarczyk proposes an accidental and rather chaotic hike. A guidebook is based on solid facts, Kobylarczyk trusts impressions and intuitions. Her narrative is governed not by graphs and maps but by the figure of labyrinth. The archetypal significance of labyrinth points to a way to a spiritual center, to self-cognition ${ }^{85}$. The labyrinth symbolizes a mystery, chaos, mess, but also infinity, complications and a trap. The figure of labyrinth is present in the urban plan of Spanish villages and cities, in incomprehensible structures of behaviors of celebrations' participants, in the mystery of symbols and rituals; and this figure makes it impossible to recognize the sense of the witnessed events ${ }^{86}$.

The experience of hierophany ${ }^{87}$ is not available for people who are not community members, but nosy onlookers, "We cannot interfere into something which is not ours, which we do not understand, and which we could - perhaps - desecrate with our barbarity" ${ }^{\prime 8}$ - the author claims. The limited epistemological competences of the subject are symbolized also by the figure of moth, fog, darkness, and a recurrent motif of a lost wanderer. Signposts mislead, maps confuse, ahaywire clock's hands lie, memory fails. We deal here with the empirical "getting lost with a guidebook," whose various variants were described by Magdalena Barbaruk, concerned with literary routes of La Mancha ${ }^{89}$.

${ }^{85}$ Y.-T. Tuan, Space and place: the perspective of experience, Minneapolis 1977.

${ }^{86}$ W. Benjamin, Das Passagen-Werk, Frankfurt am Main 2009.

${ }^{87}$ M. Eliade, The quest: history and meaning in religion, Chicago 1971.

${ }^{88}$ K. Kobylarczyk, Pył z landrynek. Hiszpańskie fiesty, Wołowiec 2013, p. 53.

${ }^{89}$ M. Barbaruk, Przewodniki błądzenia, „Acta Universitatis Wratislaviensis”, no 3649, „Prace Kulturoznawcze” nr XVII (2015), p. 171-181; idem, Sensy błądzenia. La Mancha i jej peryferie, Kraków 2018. 
Watching fiestas was reminiscent of watching someone's dreams while being awake. At night, strange cities became entangled labyrinths, nameless people got caught in the whirl of not entirely comprehensible ceremonies and among the tight crowd of their bodies we - lonely newcomers - could flit by the walls completely unpunished and unnoticed. It was easy to get addicted to this ${ }^{90}$.

The scary vastness of the interior is governed by indeterminacy and lack of closure. Timeframes crumble, space structures collapse. "Time changes into a whirl, or maybe it stops completely, it might have never flown here, in this stony town, entangled in wires, in this great country on the margin of the present"91. The reportage reality brings to life characters from a few ages ago, imagination creates figures of mythical heroes.

It seemed that all citizens escaped or hid - as if from the side of golf pitches, through unguarded gates, almagavars were to come, this motley crew of outcasts, runaways, bandits under the banners of cross and crescent, who were employed by the Crown of Aragon, these wild children of deserted Spanish desolations, who have never shaved and had their hair cut, called from Arabic muhavir - "companion," mghabbar - "dusted," and maybe simply from mughaver - "foray" 92.

These formal solutions illustrate transformations of the modern reportage described by Mateusz Zimoch, which he names a transition from the rationalist to the empirical perspective ${ }^{93}$. We all know the discomfort of Kapuściński, who a few decades ago wrote about the figure of translator hovering between cultures, trying to comprehend cultural codes alien to him and explain to the reader the hidden sense of described phenomena. Kobylarczyk does not have such limitations, the rationalist perspective - integrating, explaining the sense of textualized reality - gives way to the category of experience: individual, always unique, never attempting to generalize.

${ }^{90}$ K. Kobylarczyk, op. cit., p. 10.

${ }^{91}$ Ibid, p. 23-24.

${ }^{92}$ Ibid, p. 24.

${ }^{93} \mathrm{M}$. Zimnoch, Współczesny reportaż między racjonalizmem a doświadczeniem. Rozprawa doktorska napisana pod kierunkiem prof. dra hab. Kazimierza Wolnego-Zmorzyńskiego, Uniwersytet Warszawski, Warszawa 2014, p. 116, https://depotuw.ceon.pl/bitstream/handle/ item/1060/Mateusz Zimnoch, Współczesny reportaż (access: 02.03.2020). 
The time of myth that Kobylarczyk engenders on the pages of her reportage encompasses extreme natural phenomena (wind, thunder, lightning). The miracle is juxtaposed with ordinariness, the banal with sanctity, the sin with atonement, joy with suffering. Kobylarczyk implicitly asks about the spirituality of our times, about the sense the modern posttourist will attribute to the encounter with the poeticity of miracle, with the mysticism of ceremonies, with visualizations of universal anthrotopoi of good and evil. Pył $z$ landrynek is a wise and beautiful story about life and passing, longing for the order in the world, and universal values. This is "the lost Spain" which was the focus of Norman Lewis' words, this is the "the lost time" he was searching for.

\section{Practising Polishness: Ewa Wysocka}

It is difficult to attribute a particular genre to the book written by Ewa Wysocka, a long-time correspondent of Polish Radio in Spain. Its polymorphic form combines together elements of reportage, essay, column and guidebook. Wysocka created a narrative which is pretextual and fragmentary. The idea organizing its cognitive layer consists in Polish tropes in the cultural landscape of Barcelona. This selection originally profiles the area of peregrinations and nolens volens communicates lack of aspirations to create an exhaustive story about Barcelona. The author identifies elements in the city cultural landscape which connect it with Poland, at the same time writing a fascinating script for practicing Polishness in Barcelona. The memory map which Wysocka sketches features the most obvious places, but they are filled with the signs of Polish cultural heritage. La Rambla is mentioned because of Fryderyk Chopin, who spent a week in Barcelona in 1839. The port brings up Gombrowicz, coming back from Argentina in 1963. El Raval reminds one of Ryszard Kapuściński, who was fascinated by it; Camp Nou means a story of a Polish emigrant who played in a football team in 1911 and John Paul II addressing the crowds in Catalan. Defined so, the memory map encompasses places which are peripheral when compared with standardized tourist routes (e.g. a wayside shrine of the Mother of God of Częstochowa). Important points include spaces where artistic projects of Polish artists took place (a graphic artist Jurek Janiszewski, directors: Tadeusz Kantor, Krystian Lupa), as well as places where Polish literature was promoted (Sant Jordi Festival).

This narrative speaks through grand buildings and addresses, commemorative tablets, cafes and photographs, as well as sounds. This is confirmed in 
a gripping story of Lluís Llach and the Catalan sources of a cult song of Solidarity performed by Jacek Kaczmarski. "Polish narratives" of the city memory do not go beyond the frames of a Baedeker sketch and are not bound by a dramatic composition line. This silvarerum is rather a collection of curiosities, peculiarities. Pretextuality of the narration is one of its most important features. Polish episodes in the city life become points of reference to characterize the cultural specificity of the city. The impression about the Spanish reception of Sławomir Mrożek is a pretext to introduce a digression on censorship concerning morality in the times of General Franco; many-hours-long performances directed by Krystian Lupa lead to passages on eating habits of Catalans. Wysocka wants to talk about connections and differences of both cultures, and to look for historical episodes of mutual fascinations. This aspect of the cognitive layer is especially attractive for the Polish reader who is unaware of the Catalan reception of Polish history. Wysocka writes about Catalans' admiration for the determination of the Polish nation, who in the 18th century was deprived of their country, about respect for the heroic deeds of the Polish soldier, about a lesson which can be learned from the experience of Polish political arguments.

...for some reason we hung an invisible bridge over the Old Europe (...). The construction was supported by Spaniards, praising participants of the January Uprising of 1863, crying over their fate, and then warning that their own country would share the same fate if it did not come to its senses and stop internal arguments. It is rare for those who are oppressors - and this was the case of the Poles blindly following Napoleon on his European crusade - to have been surrounded with warm feelings ${ }^{94}$.

Another element of Polish-Spanish connections, equally unobvious for the Polish reader, concerns the analogy of Polish and Spanish experience in the course of history. Wysocka accentuates analogies of enslavement of Franco's dictatorship and the communist regime in the post-Yalta Poland. According to the author, similarities can be traced in the aesthetics of everyday life, in the authorities' aspirations to control the citizen, and even in the mentality of an individual. Wysocka's volume encompasses interesting sketches on media programming in Catalonia - TV programmes Polonia and Cracovia. The first of the proper names, strongly rooted in the linguistic usage, reproduces a catalogue of ethnic

${ }^{94}$ E. Wysocka, Barcelona stolica Polski, Warszawa 2016, p. 7. 
hereosterotypes. The Spanish word polacos is used to patronise Catalans, whose compatriots believe them to speak a strange unintelligible language. The satirical character of the programme brings to the foreground discursive potential of this narrative. Thanks to Wysocka's book, the reader can follow Poles in Barcelona, empirically verifying views on the (lack of) knowledge of Poles and Catalans about each other. This book - decidedly the weakest among the three presented ones when it comes to its author's writing skills, less impressive as a project, less documented - can be exonerated because of the originality of its concept. Polish Barcelona is a topic still new for Poles, a topic which remains important and attractive.

\section{CONCLUSIONS}

Assmann's theory of cultural memory assumes that every text of culture can be a reservoir of memory, a distributor of memory and a creator of the content of memory. The three non-fiction Polish texts presented here and focused on describing current and a bit more distant Spanish experiences constitute Baedekers of sorts, guiding the reader around the world of ideas, values and transformations of the modern Europe. This is Europe which is getting smaller, facing serious challenges of globalization, the migration crisis, still unprepared to lose its hegemonic position in the world. Reportage - a medium which is important socially and culturally - is a specially competent formula when it comes to listening to the rhythm of reality, portraying the world and its actors. It can be "a mirror being carried alonga road" (Stendhal), sometimes a seismograph of important social, cultural and political changes. The three chosen strategies of conceptualizing the reportage image of Spain are but a small prolegomenon to delineating the symbolic imaginarium of Spain from the Polish perspective at the dawn of a new millennium. It is an image interesting for the Polish reader because Spain is a country increasingly often visited by Poles, who come here as tourists, but also pilgrims, students, gastarbeiters, investors, intellectuals promoting their artistic oeuvre in Europe. What is captivating are the symmetries in the history of both countries observed in the reportages. On the other hand, what proves important is touching the priceless civilizational heritage of Spain, a dowry which has significantly determined the character of European transformation today and in the coming decades. Painted by Polish reporters, this image of Spain tells a story about the 
challenges of globalization and relationships of citizens and their state, it talks about the imperative to work through controversial episodes from the past and difficulties to find the right language to describe them, it conjures up the space of sacrum and convinces one that in the unstablepost-industrial world there are strong foundations of values and norms. These are subsequent chapters of peregrinations on the routes of cultural heritage of the Iberian Peninsula, back in the day perpetuated by Ernest Hemingway and Miguel de Unamuno in writing, by Francisco Goya and Pablo Picasso in painting, and by Luis Buñuel in montage.

\begin{tabular}{|l|l|l|l|}
\hline Research sample & Ludzie z Placu Słońca & $\begin{array}{l}\text { Pył z landrynek. } \\
\text { Hiszpańskie fiesty }\end{array}$ & Barcelona stolica Polski \\
\hline Title & Aleksandra Lipczak & Katarzyna Kobylarczyk & Ewa Wysocka \\
\hline Publishing date & 2017 & 2013 & 2016 \\
\hline Publishing house & Dowody na Istnienie & Wydawnictwo Czarne & Marginesy \\
\hline Publishment place & Warsaw & Wołowiec & Warsaw \\
\hline Volume & 254 p. & 157 p. & 227 p. \\
\hline Genre & Reportage & Reportage & Reportage \\
\hline
\end{tabular}

\begin{tabular}{|l|l|}
\hline Criteria of choosing the texts' corps \\
\hline $\begin{array}{l}\text { Inspiration and the method } \\
\text { of realizing and communi- } \\
\text { cating the journey }\end{array}$ & $\begin{array}{l}\text { cultural journey as a workshop and cognitive experience of non-fiction } \\
\text { literature }\end{array}$ \\
\hline Theme and problems & Original elements of Spain's symbolic image \\
\hline Genology & Genre variants of a Polish contemporary reportage \\
\hline
\end{tabular}

Analysis' categories: theme and morphological perspective

\begin{tabular}{|l|l|l|l|}
\hline & Ludzie z Placu Słońca & $\begin{array}{l}\text { Pył z landrynek. } \\
\text { Hiszpańskie fiesty }\end{array}$ & Barcelona stolica Polski \\
\hline theme & $\begin{array}{l}\text { Challenges of the societies } \\
\text { being globalized; laborato- } \\
\text { ry of European migration } \\
\text { experiences; memory of } \\
\text { imperial past; discourse of } \\
\text { gender; anti-system move- } \\
\text { ment; modernization }\end{array}$ & $\begin{array}{l}\text { Poetry and pragmatics of } \\
\text { Spanish fiestas; fiesta as } \\
\text { a historical, cultural, reli- } \\
\text { gious, folklore and social } \\
\text { experience; searching for } \\
\text { metaphysics in a secu- } \\
\text { larized world; symbol- } \\
\text { ism of rituals and social } \\
\text { behaviours }\end{array}$ & $\begin{array}{l}\text { Polish tracks in a cultural } \\
\text { landscape of Barcelona; } \\
\text { scenario of practicing } \\
\text { Polishness in Barcelona }\end{array}$ \\
\hline
\end{tabular}




\begin{tabular}{|l|l|l|l|}
\hline values & $\begin{array}{l}\text { Social need of narration } \\
\text { about the past; rebel po- } \\
\text { tential of citizens' society; } \\
\text { discourse of emancipation }\end{array}$ & $\begin{array}{l}\text { Cultural heritage of local } \\
\text { societies }\end{array}$ & $\begin{array}{l}\text { Connections and differ- } \\
\text { ences between Polish and } \\
\text { Spanish culture; historical } \\
\text { symmetries }\end{array}$ \\
\hline time and space & Alinearity, achronology & $\begin{array}{l}\text { Fragmentation, } \\
\text { caleidoscoping }\end{array}$ & $\begin{array}{l}\text { Giving excuses, making } \\
\text { digressions }\end{array}$ \\
\hline narration & $\begin{array}{l}\text { Polymorphism of narra- } \\
\text { tive forms: participative } \\
\text { reportage narration, por- } \\
\text { traits, interviews, investi- } \\
\text { gative journalism forms, } \\
\text { historical sketches, minia- } \\
\text { tures; art of language }\end{array}$ & $\begin{array}{l}\text { First-person reportage } \\
\text { narration combined with } \\
\text { an intimate essay context; } \\
\text { sophisticated game with } \\
\text { a guidebook convention, } \\
\text { sensual language and } \\
\text { masterful metaphore }\end{array}$ & $\begin{array}{l}\text { silva rerum poetry, first- } \\
\text { person reportage nar- } \\
\text { ration combined with } \\
\text { a sketch, anecdote and } \\
\text { column poetry }\end{array}$ \\
\hline genre & $\begin{array}{l}\text { Repotage focus on } \\
\text { problems }\end{array}$ & Literary reportage & $\begin{array}{l}\text { Reportage focus on } \\
\text { problems }\end{array}$ \\
\hline
\end{tabular}

\section{REFERENCES}

Agamben Giorgio, Homo sacer, Stanford University Press, Stanford 1998.

Alvaro J., Książka Ludzie z Placu Słońca. Recenzja i wywiad z autorkq̨: 2017, https://hispanico.pl/ksiazka-ludzie-z-placu-slonca/ (access: 09.03.2020).

Assmann Aleida, Cultural memory and western civilization: functions, media, archives, Cambridge University Press, Cambridge 2011.

Assmann Jan, Cultural memory and early civilization: writing, remembrance, and political imagination, Cambridge University Press, Cambridge 2011.

Balcerzan Edward, W stronę genologii multimedialnej, in: W. Bolecki, I. Opacki (ed.), Genologia dzisiaj, Instytut Badań Literackich, Warszawa 2000.

Barbaruk Magdalena, Przewodniki błądzenia, „Acta Universitatis Wratislaviensis”, no 3649, „Prace Kulturoznawcze” nr XVII (2015), p. 171-181.

Barbaruk Magdalena, Sensy błądzenia. La Mancha i jej peryferie, Wydawnictwo Pasaże, Kraków 2018.

Bauer Wolfgang, Über das Meer: mit Syrern auf der Flucht nach Europa, Suhrkamp, Berlin 2015.

Bauman Zygmunt, Życie na przemiał, Wydawnictwo Literackie, Kraków 2006.

Bauman Zygmunt, Ponowoczesność jako źródło cierpień, Wydawnictwo Sic!, Warszawa 2013.

Becerra Rodríguez Salvador, Religión y fiesta. Antropología de las creencias y rituales de Andalucía, Signatura Ediciones de Andalucía, Sevilla 2000.

Benjamin Walter, Das Passagen-Werk, Suhrkamp, Frankfurt am Main 2009.

Bernatowicz Maciej, Hiszpania. Fiesta dobra na wszystko, Wydawnictwo Muza, Warszawa 2017. 
Joanna Szydłowska, Three strategies of conceptualizing Spain in Polish 21st-century reportage...

Brinkbäumer Klaus, Traum vom Leben: eine afrikanische Odyssee, Fischer, Frankfurt a.M 2011.

Buczkowska Karolina, Malchrowicz Ewa, Współczesne znaczenie hiszpańskich fiest religijnych w opinii młodych polskich turystów i mieszkańców Hiszpanii, „Szczecińskie Zeszyty Naukowe. Turystyka religijna zagadnienia interdyscyplinarne" nr 647 (2011), p. 111-125.

Buczkowska Karolina, Turystyka kulturowa. Przewodnik metodyczny, Akademia Wychowania Fizycznego, Poznań 2008.

Darska Bernadetta, Recenzja Pył z landrynek. Hiszpańskie fiesty: 2017, https://kultura.onet.pl/recenzje/recenzja-pyl-z-landrynek-hiszpanskie-fiesty-katarzynakobylarczyk/sgzn0f8 (access: 2.04.2019).

Domańska Ewa, Mikrohistorie - spotkania w międzyświatach, Wydawnictwo Poznańskie, Poznań 2005.

Dziechcińska Hanna, O staropolskich dziennikach podróży, Instytut Badań Literackich PAN, Warszawa 1991.

Edensor Tim, Performing tourism, staging tourism: (re)producing tourist space and practice, „Tourist Studies” nr 1 (2001), p. 59-81.

Eliade Mircea, The quest: history and meaning in religion, University of Chicago Press, Chicago 1971.

Fajans Roman, Hiszpanja 1936. Z wrażeń korespondenta wojennego, in: M. Szczygieł (ed.), 100/XX. Antologia polskiego reportażu XX wieku, Volume 1,Wydawnictwo Czarne, Wołowiec 2014.

Fórmanowicz Dominik, Mężczyzna w chwili, gdy zostaje sam, Wydawnictwo Muza, Warszawa 2016.

Gać Jan, El Camino, czyli hiszpańskie wędrowanie, Wydawnictwo Bernardinum, Pelplin 2013.

Giddens Anthony, Nowoczesność i tożsamość. „Ja” i społeczeństwo w epoce późnej nowoczesności, A. Szulżycka (tr.), PWN, Warszawa 2012.

Giertych Jędrzej, Hiszpanja bohaterska, Ossolineum,Warszawa1937.

Goban-Klas Tomasz, Świat Ryszarda Kapuścińskiego, in: K. Wolny-Zmorzyński, W. Furman, J. Snopek (ed.), Mistrzowie literatury czy dziennikarstwa?, Wydawnictwo Poltex, Warszawa 2011.

Graff Marie Louise, Spokojnie, to tylko Hiszpania. Przewodnik po różnicach kulturowych, Julia Zabrodzka, Piotr Wciślik (tr.),Wydawnictwo Newsweek Polska, Warszawa 2007.

Grochowski Grzegorz, Pytania o niefikcjonalnq prozę dyskursywną, in: M. Czermińska (ed.), Polonistyka w przebudowie, Universitas, Kraków 2005.

Grzesiak-Feldman Monika. Tożsamościowe uwarunkowania posługiwania się stereotypami, Wydawnictwa Uniwersytetu Warszawskiego, Warszawa 2006.

Halbwachs Maurice, Społeczne ramy pamięci, M. Król (tr.), Universitas, Warszawa 2008.

Hereźniak Marta, Marka narodowa: jak skutecznie budować wizerunek i reputację kraju, Polskie Wydawnictwo Ekonomiczne, Warszawa 2011.

Janion Maria, Do Europy tak, ale z naszymi umarłymi, Wydawnictwo Sic!, Warszawa 2017. 
Jerczyńska Maria, Gospodarka elektroniczna w sektorze turystyki, „Logistyka” nr 2 (2006). Kaliszewski Andrzej, Żyrek-Horodyska Edyta, Kilka uwag o metodach analizy tekstów dziennikarskich ze szczególnym uwzględnieniem reportażu, in: A. Szymańska, M. Szymańska-Magdziarz, A. Hess (ed.), Metody badań medioznawczych i ich zastosowanie, Instytut Dziennikarstwa, Mediów i Komunikacji Społecznej, Kraków 2018.

Kamińska Agnieszka, Europejczyk w podróży: odmienność i tożsamość jako kategorie opisu świata w reportażowej twórczości Ryszarda Kapuścińskiego, Wydawnictwo Prymat, Białystok 2017.

Kamionka-Straszakowa Janina, Zbłąkany wędrowiec. Z dziejów romantycznej topiki, Zakład Narodowy im. Ossolińskich, Wrocław 1992.

Kapica-Curzyste Joanna, Fiesta forever, 2013, https://esensja.pl/ksiazka/recenzje/tekst:. html?id=16522 (access: 5.02.2020).

Witold Bereś, Krzysztof Burnetko (ed.), Nie ogarniam świata: z Ryszardem Kapuścińskim, Świat Książki, Warszawa 2007.

Kapuściński Ryszard, Rwący nurt historii. Zapiski o XX i XXI wieku, Wydawnictwo Znak, Kraków 2008.

Kieniewicz Jan, Hiszpania w zwierciadle polskim, Novus Orbis, Gdańsk 2001.

Kinsley Patrick, New odyssey: the story of the twenty-first-century Europe's refugee crisis, Norton \& Co Inc, New York 2016.

Kita Barbara, Między przestrzeniami. O kulturze nowych mediów, RABID, Kraków 2003.

Kobylarczyk Katarzyna, Pył z landrynek. Hiszpańskie fiesty, Wydawnictwo Czarne, Wołowiec 2013.

Kunce Aleksandra, Antropologia punktów, Wydawnictwo Uniwersytetu Śląskiego, Katowice 2008.

Kuncewiczowa Maria, Don Kichot i niańki, Wydawnictwo Lubelskie, Lublin 1990.

Lacan Jacques, Funkcja i pole mówienia i mowy w psychoanalizie, B. Gorczyca, W. Grajewski (tr.),Wydawnictwo KR, Warszawa 1995.

Lewis Norman, Voices of the Old Sea, Viking, New York 1984.

Lewis Norman, The Tomb In Seville, Jonathan Cape, London 2003.

Liberti Stefano, A sud di Lampedusa: cinque anni di viaggi sulle rotte dei migranti, Minimum fax., Roma 2011.

Lipczak Aleksandra, Ludzie z Placu Słońca, Wydawnictwo Dowody na Istnienie, Warszawa 2017.

W Hiszpanii wszystko jest bardziej, 2017, With Aleksandra Lipczak talking M. Bojanowska, K. Chojnacka, „Nowy Folder”, 03.05.2017, http://www.nowyfolder.com/aleksandralipczak-w-hiszpanii-wszystko-jest-bardziej/ (access: 11.03.2020).

Reportaż/wywiad. With Aleksandra Lipczak talking M. Majewska, „Krytyka Polityczna” from 23.09.2017, https://krytykapolityczna.pl/swiat/aleksandra-lipczak-hiszpania-reportaz-wywiad/ (access: 01.03.2020).

Historia, reportaż. With A. Lipczak talking M. Wilk, \#rozmowyliczanki [ep. 38] from 18.12.2017, https://www.youtube.com/results?search_query=lipczak+rozmowyliczanki (access: 12.03.2020). 
Łukasiewicz Krzysztof; Topp Izolda, „Przewodniki w kulturze i kultura jako przewodnik”, „Prace Kulturoznawcze” nr 17 (2015), p. 9-13.

MacCanell Dean, Tourist: a new theory of the leisure class, Schocken Books, New York 1989.

Majewska Anna Klara, Rok na Majorce, Wielka Litera, Kraków 2013.

Malchrowicz-Mośko Ewa; Buczkowska Karolina, Fiesty hiszpańskie - jeszcze święta lokalne, czy już tylko atrakcje dla turystów?, „Turystyka Kulturowa” nr 4 (2010), p. 17-37.

Marchwica, Recenzja Pył z landrynek: 2017, http://etnosystem.pl/ksiazka/recenzje/7194kobylarczyk-pyl-z-landrynek (access: 10.03.2020).

Matheson Donald, Allan Stuart, Digital war reporting, Wiley, Oxford 2013.

Mączak Antoni, Peregrynacje. Wojaże. Turystyka, Książka i Wiedza, Warszawa 1984.

Mikos von Rohrscheidt Armin, Turystyka kulturowa. Fenomen, potencjał, perspektywy, Kultour.pl, Poznań 2010.

Morgause, Pył z landrynek. Hiszpańskie fiesty, 2015, https://www.biblionetka.pl/art. aspx?id=939259 (access: 7.03.2020).

Murray Douglas, Strange death of Europe: immigration, identity, islam, Bloomsbury, London 2017.

Narębska Ilona, Panorama histórico de las traducciones de la literatura Polaca publicadas en España de 1939 a 1975, tesis doctoral, Universidad de Alicante Facultad de Filosofía y Letras Departamento de Traducción e Interpretación, Alicante 2011.

Nijakowski Lech, Polska polityka pamięci. Esej socjologiczny, Wydawnictwa Akademickie i Profesjonalne, Warszawa 2008.

Nooteboom Cees, Roads to Santiago: A Modern-Day Pilgrimage Through Spain, Harvill Press, London 1997.

Nora Pierre, Les lieux de memoire, Quarto Gallimard, Paris 1997.

Olechowska Marzena, Chołopiak Grzegorz, Hiszpania jakiej nie znacie. Kastylia - la Mancha. W krainie błędnych rycerzy i wiatraków, Wydawnictwo Poligraf, Brzezia Łąka 2013.

Dudko B. (ed.), Podróże z Kapuścińskim. Opowieści trzynastu tłumaczy, Wydawnictwo Znak, Kraków 2007.

Pruszyński Ksawery, W czerwonej Hiszpanii, Wydawnictwo Rój, Warszawa 1937.

Przewieczerski Jerzy, Hiszpania w ogniu: reportaż z 22 rycinami, Księgarnia Wł. Michalak i S-ka, Warszawa 1936.

Remarque Erich Maria, Noc w Lizbonie, R. Wojnakowski (tr.), Dom Wydawniczy Rebis, Warszawa 2015.

Ricoeur Paul, Pamięć, historia, zapomnienie, J. Margański (tr.), Universitas, Kraków 2006.

Rybczyńska Zoriana, Potęga i niemoc spojrzenia Meduzy: alternatywne przewodniki miejskie jako realizacja nowej utopii, „Prace Kulturoznawcze” nr XVII (2015), p. 129-141.

Raval, dzielnica Barcelony, to była miłość od pierwszego wejrzenia. With Aga Sarzyńska talking Michał Nogaś, „Duży Format” nr 29 (2017), p. 23-24.

Sarzyńska Aga, Barszalona, Wydawnictwo Literackie, Kraków 2017. 
Snyder Timothy, Black Earth: the Holocaust as History and Warning, Crown/Archetype, eBook 2015.

Stasiak Andrzej, Włodarczyk Bogdan; Śledzińska Jolanta, Wczoraj, dziś i jutro krajoznawstwa, in: A. Stasiak, B. Włodarczyk, J. Śledzińska (ed.), Współczesne oblicze krajoznawstwa, Warszawa 2016.

Stępnik Krzysztof, Dekonstrukcja reportażu. (Zygmunta Nowakowskiego „Niemcy a la minute...”), in: M. Woźniakiewicz-Dziadosz (ed.), Fabularność i dekonstrukcja, Wydawnictwo UMCS, Lublin 1998, p. 165-166.

Stochniałek Hanna, En busca de las normas de traducción: la prosa polaca traducida en España y en México: estudio del caso. Rozprawa doktorska, Uniwersytet Warszawski 2005, Editorial Académica Española - LAP Lambert Academic Publishing, Saarbrücken 2012.

Sznayder Jan, Podróże w starożytności, Państwowe Zakłady Wydawnictw Szkolnych, Warszawa 1959.

Traba Robert, Historia - przestrzeń dialogu, Instytut Studiów Politycznych PAN, Warszawa 2006.

Tuan Yi-Fu, Space and place: the perspective of experience, University of Minnesota Press, Minneapolis 1977.

Urry John, Socjologia mobilności, J. Stawiński (tr.),Wydawnictwo Naukowe PWN, Warszawa 2009.

Warneńska Monika, Zwierciadło z Toledo, Wydawnictwo Ministerstwa Obrony Narodowej, Warszawa 1985.

Warnke Agnieszka, Aleksandra Lipczak, Ludzie z Placu Słońca from 20.05.2017,https://culture.pl/pl/dzielo/aleksandra-lipczak-ludzie-z-placu-slonca) (access: 09.03.2020).

Wieczorkiewicz Anna, Apetyt turysty. O doświadczaniu świata w podróży, TAiWPN, Universitas, Kraków 2008.

Wiernikowska Maria, Oczy czarne, oczy niebieskie. Z drogi do Santiago de Compostela, Wydawnictwo Zwierciadło, Warszawa 2013.

Wimmer Roger D., Dominick Joseph R., Mass media. Metody badań, T. Korłowicz (tr.), Wydawnictwo Uniwersytetu Jagiellońskiego, Kraków 2008.

Wolnik-Vera Katarzyna, Przystanek Barcelona, Burda NG, Warszawa 2014.

Wolnik-Vera Katarzyna, Siewak-Sojka Zofia, Costa del Sol i Costa de la Luz, Wydawnictwo Pascal, Bielsko-Biała 2018.

Wołowiec Grzegorz, O Domosławskim i jego krytykach, „Teksty Drugie” nr 1-2 (2011), p. 279-288.

Wysocka Ewa, Barcelona stolica Polski, Marginesy, Warszawa 2016.

Zajas Krzysztof, Zagubieni kosmonauci. Raz jeszcze o "Imperium" Ryszarda Kapuścińskiego i jego krytykach, „Teksty Drugie” nr 3 (2010), p. 218-231.

Zamelska Maria, Kaczor Beata, Interaktywne formy współczesnego krajoznawstwa na przykładzie Wielkopolski. in: A. Stasiak, B. Włodarczyk, J. Śledzińska (ed.), Współczesne oblicze krajoznawstwa, Warszawa 2016, p. 315-328. 
Zimnoch Mateusz, Współczesny reportaż między racjonalizmem a doświadczeniem. Rozprawa doktorska napisana pod kierunkiem prof. dra hab. Kazimierza Wolnego-Zmorzyńskiego, Uniwersytet Warszawski, Warszawa 2014, https://depotuw.ceon.pl/bitstream/handle/item/1060/Mateusz\%20Zimnoch\%2C\%20Wsp\%C3\%B3\%C5\%82 czesny\%20reporta\%C5\%BC\%20-\%20mi\%C4\%99dzy\%20racjonalizmem \%20 a\%20do\%C5\%9Bwiadczeniem.pdf?sequence=1 pdf.

\section{Biogram}

Dr hab. Joanna Szydłowska, prof. nadzw. - olsztynianka, pracuje w Instytucie Dziennikarstwa i Komunikacji Społecznej Uniwersytetu Warmińsko-Mazurskiego w Olsztynie. Zajmuje się genologią dziennikarską oraz medialnym i literackim zapisem doświadczeń pogranicza kulturowego. Jest autorką monografii reportażu polskiego (Warmia i Mazury w reportażu polskim w latach 1945-1980. O tożsamości bohaterów, miejsc i zdarzeń, Olsztyn 2001), pracy o sposobach kreacji dyskursu o ziemiach włączonych do Polski w wyniku rozstrzygnięć II wojny światowej (Narracje pojałtańskiego Okcydentu. Literatura polska wobec pogranicza na przykładzie Warmii i Mazur (1945-1989 Olsztyn 2013) oraz zbioru szkiców o pograniczu polsko-niemieckim (Kostiumy, figury, dekoracje. Szkice z pogranicza, Olsztyn 2018). Opracowała tomy antologii reportaży i felietonów; jest redaktorką kilku prac zbiorowych. Publikuje m.in. w „Ruchu Literackim”, „Anthroposie?”, „Tematach z Szewskiej”, „Napisie”.

E-mail: joanna.szydlowska@uwm.edu.pl

ORCID: 0000-0002-2038-2283 
KULTURA - MEDIA - TEOLOGIA

ISSN 2081-89-71

$2020 \mathrm{nr} 40$, s. $76-96$

\title{
Witold Kawecki
}

\author{
Uniwersytet Kardynała Stefana Wyszyńskiego w Warszawie
}

\section{Fenomen teologii wizualnej i sposoby jej komunikowania}

\section{The phenomenon of Visual Theology and ways to communicate it}

\begin{abstract}
ABSTRAKT
We współczesnej kulturze wizualnej, dominującej coraz bardziej, można zauważyć formowanie się koncepcji teologii wizualnej.

Nie jest ona prostym odzwierciedleniem teologii obrazu, nie jest tożsama z teologią piękna - bo nie jest ona teologią przedmiotu

(treści i form religijnych). Jest ona raczej teologią podmiotu poznającego i samego poznawania za pośrednictwem zmysłu wzroku. Autor określa i systematyzuje pojęcia związane z tak funkcjonującą teologią,

a jednocześnie wskazuje na najbardziej adekwatne metody, dzięki którym może ona być skutecznie komunikowana.

SŁOWA KLUCZOWE:

kultura wizualna, teologia wizualna, metody uprawiania teologii wizualnej, fides ex visu
\end{abstract}

\begin{abstract}
In contemporary visual culture, which become more and more dominant, one can see the emergence of the concept of visual theology. It is not a simple reflection of theology of the image, it cannot be identified with the theology of beauty, because it is not theology of the subject (content and form of religion). It is rather the theology of the cognizing subject and the cognition itself through the senses of sight. The author defines and systematizes the concept related to such functioning theology and at the same time points to the most adequate methods by which he can effectively communicate.
\end{abstract}

\section{KEYWORDS:}

visual culture, visual theology, methods of practicing visual theology, fides ex visu

\section{WPROWADZENIE}

Zwykło się przyjmować, że chrześcijaństwo jest religią słowa. Trudno z tą tezą polemizować, tym bardziej, że Bóg stał się Słowem Wcielonym, a Księgi Święte od tysiącleci przemawiają do nas Słowem Boga. Jednak zgodnie z obserwowanym od jakiegoś czasu zwrotem kulturowym - od logocentryzmu w kierunku wzrokocentryzmu - coraz częściej dostrzegamy rolę, jaką w rozpoznawaniu i doświadczeniu 
wiary odgrywa obraz. Poznając historię chrześcijaństwa, nie sposób nie zauważyć funkcji, jaką spełnił on w zrozumieniu tajemnicy Boga, który na różne sposoby objawiał się człowiekowi. Zresztą, któż z nas nie chciałby zobaczyć Boga, doświadczyć Jego obecności w sposób graniczący z pewnością, ujrzeć Jego Oblicze. Współczesny człowiek nie tylko chce słyszeć o Chrystusie: chce Go zobaczyć, aby Go też kontemplować, gdyż jest On „najpiękniejszym spośród synów ludzkich” (Ps 45,3). Ta kontemplacja może być zarówno w Jego Obliczu boskim, jak i ludzkim, skoro był jednym z nas. Z tego względu komunikacja wiary poprzez obraz rysuje się jako niezwykle istotna dla współczesnej ewangelizacji i staje się nakazem chwili. W świecie zdominowanym przez kulturę wizualną, Kościół nie może zaniedbać tej formy przekazu i komunikacji, wypracowując coraz pełniej koncepcję teologii wizualnej. Papież Jan Paweł II nie omieszkał zauważyć w tym względzie: „Kościół potrzebuje obrazu. Ewangelia wyraża się w wielu obrazach i porównaniach; Ewangelia powinna i może być ukazana w formie obrazów. W Nowym Testamencie Chrystus jest nazwany Obrazem, Ikoną niewidzialnego Boga. Kościół jest nie tylko Kościołem słowa ale także Kościołem sakramentów, świętych znaków i symboli. Przez długi czas obrazy, obok słów, ukazywały orędzie zbawienia tak też dzieje się do dzisiaj. To dobrze. Wiara zwraca się nie tylko do słuchu, ale i do wzroku, do obu tych podstawowych zdolności człowieka"1.

Każdy spotyka się w życiu z wieloma obrazami, żyje pośród nich, sam je tworzy i na nie patrzy. Każdy też ma prawo do patrzenia, do widzialności - czyli percepcji tego, co widzi, i to w sposób autonomiczny. Nie oznacza to bynajmniej aprobaty skrajnego indywidualizmu patrzenia i voyeryzmu, a także różnych współczesnych form ikonomanii czy ikonolatrii wyrażających się w niemożności życia bez obrazów i nadmiernym akcentowaniu samego przedmiotu widzenia. Prawo do patrzenia nie oznacza także próby uprzedmiotowienia osoby, „zawłaszczania" innych osób, manipulacji nimi przy użyciu różnego rodzaju obrazów, co szczególnie widoczne jest w kulturze konsumistycznej. Obrazu mimo jego kulturowego znaczenia nie można gloryfikować, nawet, jeśli się przyjmie za prawdziwą tezę - jak chciał tego Jan Damasceński - że cała stworzona rzeczywistość posiada znaczenie obrazu sakralnego, bo przez jej postrzeganie i pojmowanie, człowiek zdolny jest wznieść umysł ku sferze ducha. Mimo to trzeba pamiętać, że i tak

${ }^{1}$ Jan Paweł II, Kościół potrzebuje sztuki, w: Jan Paweł II, Nauczanie Papieskie, III, 2, Poznań-Warszawa 1980, s. 695. 
obraz pozostanie tylko obrazem, prototypem, punktem odniesienia, narzędziem komunikacji, nie zastępując samego podmiotu i przedmiotu komunikacji. Mówi się, że obrazy nie kłamią, gdy tymczasem obrazy mogą kłamać, tj. dysymulować - ukrywać bądź taić, bądź też udawać, że nie posiadają tego co mają, bądź też mogą symulować, a więc udawać, że posiadają coś, czego tak naprawdę nie mają. Wystarczy w tym względzie analizować codzienną rzeczywistość medialną pełną różnego rodzaju przekłamań przy użyciu obrazów. W jakimś sensie spór ikonoklastów z ikonofilami dotyczył tych właśnie kwestii i pobrzmiewa on po dziś dzień. Nie ulega wątpliwości, że współcześnie obraz w dużej mierze został zredukowany do czystej wartości technologicznej, przeciwstawiony słowu, zredukowany do fotografii, także w przestrzeni kościelnej, i w konsekwencji dotknięty został sztucznością. Z tego względu moim zamierzeniem jest wskazanie na taką rolę obrazu, w której jest on zdolny poprowadzić podmiot poza materialną oczywistość, obudzić świat wewnętrznych przeżyć i nauczyć nowego sposobu widzenia - by $\mathrm{w}$ widzialnym dostrzec niewidzialne.

\section{CZYM JEST TEOLOGIA WIZUALNA?}

Jeśli przyjmiemy, że widzialne obrazy są widzialnym odbiciem rzeczy niewidzialnych, to poprzez ich studium dojść możemy do duchowego poznania, tak istotnego z punktu widzenia teologii. Człowiek poniekąd rodzi się, kiedy doświadcza widzenia, choć ono samo jest niewidzialne: nie widzimy, czym jest widzenie. Postrzeganie świata rodzi świadomość, a ta pozwala nam coś więcej niż widzieć mianowicie odczuwać, co nie jest niczym innym, jak wrażliwością na widzenie. Triada pokazać - widzieć - zobaczyć zdaje się być fundamentalną zasadą w tym względzie. „Pokazać” uosabia różnego rodzaju obrazy obecne we współczesnej kulturze wizualnej - obraz mentalny, medialny, techniczny, naturalny, wydarzenie wizualne (visual event), obraz audialny, obraz rozumiany zarówno jako picture jak i image. Widzenie poprzedza bowiem słowa; jest pierwotne jak u dziecka, które najpierw patrzy i rozpoznaje, a dopiero potem zaczyna mówić. Widzenie, które jest czynnością niezwykle aktywną, prowadzi nas do „patrzenia” - widzimy tylko to, na co patrzymy, a owo patrzenie jest aktem wyboru. Sposób, w jaki patrzymy i w konsekwencji postrzegamy rzeczy, zależy z jednej strony od naszej wiedzy, a z drugiej od naszej wiary. Są też różnego rodzaju sposoby patrzenia, służące temu, aby naprawdę widzieć - które stają się jednocześnie sposobami 
interpretacji obrazów: semiologia, psychoanaliza wizualności, podejście antropologiczne, interpretacja kompozycyjna czy wreszcie analiza obrazu filmowego. Ale obrazy są nie tylko po to, aby widzieć, lecz również aby „zobaczyć” to, co nie zawsze jest oczywiste, a co należy odkrywać wpatrując się w ich głębię i poza nie, aby zobaczyć coś więcej, aniżeli obraz może ukazać.

We współczesnej kulturze nazywanej wizualną obrazy odgrywają prymarną rolę, bo to one w znacznej mierze przenoszą informacje, wiedzę, przekazują emocje, doznania estetyczne, wyrażają wartości, a nawet wiarę. Obrazy stają się przedmiotem świadomego rozszyfrowania i oddziałują na podświadomość, a więc stają się przedmiotem studium, a ludzie czytają je jak tekst. Początkowo dotyczyło to tylko obrazu statycznego i fotografii. Wraz z rozwojem elektronicznego i cyfrowego rejestrowania obrazu, kopiowania, przetwarzania i przenoszenia obrazu w postaci taśmy filmowej, telewizji, komputera i Internetu, zakres odbioru stał się całkowicie nieograniczony. Wytworzył się w ten sposób nowy typ komunikacji międzyosobowej nazwanej komunikacją wizualną. Jest ona świadomym działaniem zmierzającym do nawiązania kontaktu z drugim człowiekiem, z niewidzialnym światem transcendencji, z Bogiem. Działania te polegają na specyficznym zachowaniu wykorzystującym wzrok, często mimikę, gestykulację, czy użycie specjalnie wytworzonych obiektów pośredniczących w kontakcie. Zarówno zachowaniom tym, jak i obiektom nadaje się funkcje komunikatu, bazujące na postrzeganiu wzrokowym. Owa komunikacja wizualna powinna odkrywać teologię zawartą $\mathrm{w}$ dziełach sztuki i jednocześnie analizować sztukę obrazu jako przestrzeń i przedmiot studiów teologicznych. Powinna być próbą ukazania istniejących relacji pomiędzy sztuką a wiarą i dróg do niej prowadzących, w postaci choćby „via pulchritudinis” - drogi piękna.

$\mathrm{W}$ analizach na temat roli i znaczenia obrazu w komunikowaniu wiary warto zwrócić uwagę na szerszy kontekst kultury, której jesteśmy uczestnikami, na przestrzeń, którą zwykliśmy nazywać ikonosferą. Jest ona wizualnym środowiskiem człowieka z całokształtem otaczających go obrazów i stanowi dziś przedmiot różnego rodzaju studiów kulturoznawczych, filozoficznych, socjologicznych a ostatnio coraz częściej i teologicznych. Posługiwanie się obrazem i umiejętność jego interpretacji domaga się jednak „kompetencji obrazowej”, tym bardziej, że sam obraz staje się złożoną i problematyczną rzeczywistością. Szeroko rozumianym pojęciem obrazu i sposobami jego postrzegania zajmują się nowe dziedziny naukowe jak, choćby Visual Culture Studies, napotykając jednak w jego 
rozumieniu wiele trudności, takich jak: niejednoznaczność samych obrazów, ich różnorodne używanie, brak wystarczających kryteriów ich oceny, nachalność obrazowania prowadząca do niewrażliwości na obrazy, ekspansja wizualności marginalizująca funkcję słowa i spłaszczająca poznawanie rzeczywistości, itp. Pozostaje pytaniem otwartym, czy obrazy należy „czytać” tylko z punktu widzenia estetyki, historii sztuki (zawężając wtedy ich obszar badawczy), czy też należy ich interpretację rozszerzyć o kontekst interdyscyplinarny, obszar wytwarzania, obszar samego obrazu i obszar odbiorczości. W moim mniemaniu istnieje potrzeba szerszego spojrzenia na obraz z punktu widzenia teologii kultury i teologii mediów, a zwłaszcza z perspektywy antropologii teologicznej, w której punktem wyjścia jest obraz człowieka - czyli ludzki świat myśli, jego zdolność do artystycznego wypowiadania się, możliwość wychodzenia człowieka poza siebie, czyli tzw. transcendowanie.

\section{Obrazy stają się przedmiotem świadomego rozszyfrowania i oddziałują na podświadomość, a więc stają się przedmiotem studium, a ludzie czytają je jak tekst.}

Sferą, w której obraz intensywnie oddziałuje na wszystkie przestrzenie życia, jest też kultura wizualna. Czym ona jest? Jako rodzaj studiów wizualnych jest po trosze i historią sztuki i estetyką, ale także techniczną i naukową formą obrazowania, która obejmuje film, telewizję czy media cyfrowe. Jest także refleksją filozoficzną w dziedzinie epistemologii widzenia, semiotyczną analizą obrazów, psychoanalizą „popędu” skopicznego, psychologicznym badaniem mechanizmu widzenia, antropologią wizualną, optyką fizyczną, a także socjologiczną analizą pokazywania i oglądania². Częścią kultury jest też teologia, a w naszym konkretnym przypadku teologia wizualna. Chociaż więc przyjmuje się, że wiara zastępuje widzenie $^{3}$, to jednak w porządku poznawczym (fides querens intellectum) wiara

${ }^{2}$ W.J.T. Mitchell, Pokazać widzenie, w: I. Kurz, P. Kwiatkowska, Ł. Zaremba (red.), Antropologia kultury wizualnej. Zagadnienia i wybór tekstów, tłum. Ł. Zaremba, Warszawa. 2012, s. 58.

${ }^{3}$ B. Chenu, Disciples d'Emmaus, Paris 2003, s. 80. 
potrzebuje też widzenia. Przy czym triada „pokazać - widzieć - zobaczyć” nabiera tu innego znaczenia: wskazuje na stopniowe przenikanie teologii obrazu (visibile) w kierunku teologii poznania poprzez widzenie (visum), aż po teologię podmiotu poznającego w widzeniu (videns). Teologia wizualna nie jest zatem prostym odzwierciedleniem teologii obrazu, nie jest tożsama z teologią piękna - bo nie jest ona teologią przedmiotu (treści i form religijnych). Jest raczej teologią podmiotu poznającego i samego poznawania za pośrednictwem zmysłu wzroku. Jak słusznie zauważa A. Draguła, teologia wizualna „(...) nie jest teologią tego, co pokazane, ale tego, co zobaczone. Jest teologią patrzącego i światła, które jest konieczne, by $\mathrm{z}$ widzenia przejść do zobaczenia. Tym światłem jest wiara, która pozwala przekształcać widzącego (spectans) w tego, który zobaczył (videns). To ona pozwala zobaczyć to, co święte tam, gdzie inni zatrzymują się tylko na widzeniu-patrzeniu"4. Teologia powinna w coraz większym stopniu nawiązywać dialog z naukami badającymi fenomen wizualności, spotykając się z nimi w interdyscyplinarnym zwrocie wizualnym, aby móc w ten sposób odgrywać ważną rolę w nauce, by jej głos liczył się jako inspirująca i ważna refleksja nad kulturą.

\section{Teologia wizualna nie jest zatem prostym odzwierciedleniem teologii obrazu, nie jest tożsama z teologią piękna - bo nie jest ona teologią przedmiotu (treści i form religijnych). Jest raczej teologią podmiotu poznającego i samego poznawania za pośrednictwem zmysłu wzroku.}

Współcześnie, jak to ma miejsce choćby w teologii wizualnej, obraz nie jest traktowany jako prosta ilustracja np. biblijnego tekstu (Biblia Pauperum). Rozumie się go szerzej, jako pewnego rodzaju interpretację, ponowne odczytanie, naświetlenie tradycji i kultury, którą interpretuje. W tym sensie należy zauważyć, że

${ }^{4}$ A. Draguła, Teologia wizualna. Kwadrat hermeneutyczny (artysta, dzieło, odbiorca, wiara), w: W. Kawecki (red.) Wierzyć i widzieć, Sandomierz 2013, s. 29. 
obraz ma swój własny „język” wyrazu, który otwiera drogę do mnogości możliwych znaczeń, odsyła o wiele bardziej niż kultura werbalna do symboliki poprzez użycie kodów ikonograficznych. Obraz akcentuje sensytywność i świat emocji, tj. cielesność ludzkiej egzystencji. Obraz domaga się dialogu-spotkania między oglądającym a konkretnym dziełem, biorącym pod uwagę różnorodność psychologicznych postaw oglądającego, jak i pojęcia czasowości i ponadczasowości dzieła. Obraz o wiele bardziej niźli tekst podkreśla relację, jaka istnieje między postaciami danej sceny, ze względu na ich gesty, charakterystyczne postawy, wyraz twarzy, mimikę, grę spojrzeń, wyrażane emocje, nie mówiąc już o grze kolorów, światło-cienia, dynamizmu ruchu w nim zawartego. W historii chrześcijaństwa dowartościowanie obrazu dokonało się przez fakt Wcielenia. Bóg wchodząc w historię ludzką spotyka ludzi w ciele i krwi, zbawia ich w wymiarze duchowym i cielesnym. Z tego względu teologowie i egzegeci biorą pod uwagę obraz nawet wtedy, gdy interpretują tekst, odkrywając w ten sposób głębiej prawdziwe człowieczeństwo bytu ludzkiego w jego harmonijnym jestestwie cielesno-duchowym, przechodząc od abstrakcji do konkretu5. Istnieją współcześnie mocne tendencje zmierzające do zintegrowania „sztuki obrazu” z teologią, przy uwzględnieniu jej obecności i wkładu w poszczególne dyscypliny teologiczne. Współczesność powinna odkrywać teologię zawartą w dziełach sztuki i jednocześnie analizować sztukę obrazu jako przestrzeń i przedmiot studiów teologicznych. Nie chodzi przy tym o rozwijanie - kolejny raz jak to miało miejsce w historii - dyskursu teologicznego na temat różnych form artystycznych, nie zostawiając im możliwości „bycia sobą" i wyrażania całej ich potencjalności. Chodzi raczej o wykazanie, jak sztuka obrazu i teologia pochodzą z tej samej formy aktywności ludzkiej - kultury, a zatem rozważenie kulturowego wymiaru teologii i teologicznego wymiaru kultury. Czyni to m.in. teologia wizualna, która nie jest w swej istocie teologią piękna, ani nawet teologią obrazu jako takiego: nie jest teologią tego, co pokazane, ale tego, co zobaczone. Analogicznie więc do teologii słowa Bożego, w której teologia słowa musi być uzupełniona teologią słuchania oraz teologią słuchacza, także i tutaj, w obszarze teologii wizualnej, teologia obrazu musi zostać uzupełniona teologią patrzenia i teologią patrzącego. Jeszcze inaczej mówiąc, oprócz teologicznego namysłu nad przedmiotem poznania (visibile), potrzebny jest taki sam namysł nad

${ }^{5}$ B. Neipp, Apporto dell'imagine al testo biblico dalla prassi nella Chiesa all'approcio scientific, w: E. Genre, Y. Redalie' (red.), Arte e teologia, Torino 1997, s. 95. 
teologią poznania poprzez widzenie (visum) oraz teologią podmiotu poznającego poprzez widzenie (videns). Teologia współczesna przedstawia się jako specyficzny rodzaj mediacji między wiarą i kulturą, w tym kulturą artystyczną. Teologia jawi się jako opus fidei, owoc wiary w Chrystusa, ale jednocześnie znaczący wyraz kultury, zwłaszcza religijnej, choć nie tylko. Ponieważ w teologii chrześcijańskiej zbiegają się ze sobą wiara i kultura, może być ona zatem widziana - i powinna - jako rodzaj specyficznej mediacji wiary chrześcijańskiej i kultury ludzkiej. W historii dziejów teologowie niejednokrotnie usiłowali poprzez intellectus fidei wyjaśniać bogactwo tajemnicy Chrystusa w uwarunkowaniach kulturowych. I choć były także okresy dramatycznego rozejścia się wiary i kultury, współcześnie na nowo podejmuje się wysiłki przywrócenia słusznej równowagi pomiędzy nimi. Teologia pozostaje w służbie wspólnoty ludzkiej, nie tylko kościelnej. Z tego względu współczesny teolog jest powołany do refleksji na temat kultury i do tworzenia nowej kultury. Teologia z natury rzeczy „dotyka” z jednej strony rzeczywistości epifanii, wyraża wiedzę o Najwyższym i Transcendentnym, z drugiej zaś ukazuje Boga, który czyni się widocznym, co więcej: powierza się ludzkim siłom, wchodzi w kulturę, daje się zrozumieć. Teologia bez kultury zanika, zamiera w anonimowości i skostniałej abstrakcyjności. Kultura bez teologii traci to, co w niej najistotniejsze - swoje nadprzyrodzone przeznaczenie. Teologia nie może uciekać od kultury, pozostawać wobec niej w relacjach nieufności czy nawet wrogości. Teologia (przynajmniej w swojej części), będąc wrażliwa na dokonujące się zmiany kulturowe, zawsze znajdowała sposoby na adekwatne wyzwania czasów, tworząc różne nurty teologiczne - teologii laikatu, teologii rzeczywistości ziemskiej, teologii pracy, teologii polityki, teologii ciała, teologii obrazu, teologii kultury i sztuki, teologii piękna, czy wreszcie teologii wizualnej.

Wszystkie te zamierzenia domagają się jednak skonkretyzowania definicji teologii, jej przedmiotu formalnego, jej celów i metod poznania teologicznego, potrzebnego do przewidzianych badań. Warto zauważyć, ze teologia ma trzy wymiary - naukowy, eklezjalny i duchowy - harmonijnie współpracujące między sobą. Jeśli przyjmiemy, że teologia to systematyczna refleksja (a zatem naukowa) nad Objawieniem, że jest to mowa o Bogu rozwijana we wspólnocie Kościoła w postawie wiary i oświecona łaską, to wychodzi w tej definicji cała natura teologii warunkująca metodę teologiczną. Teologia jest dziedziną wiedzy, która charakteryzuje się metodą i przedmiotem formalnym. Przedmiotem tym jest Bóg i Jego poznanie, a sam proces poznania teologicznego nazywany jest uprawianiem 
teologii. Ponieważ mówienie i pisanie o Bogu jako o przedmiocie budzi zastrzeżenia, zwykło się inaczej określać przedmiot tej dziedziny wiedzy. Jest nim mianowicie Słowo Boże, czyli Objawienie, wiedza o wierze (scientia fidei, intellectus fidei) w sensie treści wiary. Przedmiotem teologii jest też człowiek (rozumie się tu też wspólnotę wierzących, a nawet wspólnotę ogólnoludzką) widziany w kontekście historii zbawienia i w świetle Słowa Bożego. Przedmiotem teologii jest Chrystus, ponieważ nie ma innego misterium Boga poza Chrystusem, który przenika całą historię rodzaju ludzkiego. Z kolei celem teologii jest kultura wiary, tj. wiara świadoma, refleksyjna, zinterioryzowana, odpowiedzialna, dojrzała (inteligentia fidei), ale także mądrość chrześcijańska pomagająca człowiekowi lepiej żyć. Celem teologii jest też służba Słowu Bożemu i Kościołowi, ponieważ teologia buduje most między Objawieniem a człowiekiem.

\section{JAKIE METODY WINNY BYĆ STOSOWANE W OBRĘBIE TEOLOGII WIZUALNEJ?}

Pozostaje podstawowym pytanie: dzięki jakim metodom możliwe będzie skuteczne uprawianie i w konsekwencji komunikowanie teologii wizualnej? Jest to tak naprawdę tworzenie metodologicznych podstaw teologii wizualnej, a jednocześnie pytanie o sposoby, które warunkują poznanie naukowe. Ogólnie można powiedzieć, że istnieją dwie drogi poznania teologicznego - odgórna i oddolna. Odgórna bierze pod uwagę absolutną suwerenność Boga i autorytet Jego Słowa. Za najważniejsze uważa się to, co Bóg mówi do mnie. Podstawą w niej jest Boże słowo, które analizuje się przy pomocy różnych metod, porównując je ze swoją wiedzą, i w ten sposób rodzi się teologia. Oddolna zawiera w sobie dużą dozę antropocentryzmu - wychodzi od sytuacji człowieka, którego próbuje zrozumieć siebie w świetle Objawienia. Biorąc pod uwagę historię myśli teologicznej można wymienić kilka metod uprawiania teologii. Metoda integralna zakłada, że wykorzystuje się wszystkie źródła teologii, aby wszechstronnie poznać orędzie Boga, wiążąc je z całokształtem wiary i teologii, a więc uwzględniając osiągnięcia innych dyscyplin naukowych. Metoda scholastyczna bazuje na formie wykładu, który przybiera ustalone formy - postawienie problemu, racje przeciw, racje za, właściwy wykład i rozwiązanie, odpowiedzi na zarzuty, czyli rozwiązanie powstałych trudności. Metoda pozytywna to taka, w której wychodzi się z prymatu danych pozytywnych tj. Pisma Świętego i Tradycji, następnie dokonuje się analizy 
tekstów z uwzględnieniem właściwej hermeneutyki (umiejętności interpretacji tekstów literackich i źródeł historycznych, a w szerszym znaczeniu, także wszelkich treści symbolicznych), dochodząc do syntezy. Stosuje się w niej indukcję, rezygnując z dedukcji (funkcja rozumu w tej metodzie ulega znacznemu ograniczeniu, gdyż wysiłek intelektualny koncentruje się na ustaleniu co Bóg objawił, a nie na ludzkiej spekulacji w tym względzie). W metodzie mieszanej próbuje się łączyć dwie poprzednie metody czyli metodę scholastyczną i pozytywną. Istnieje też metoda regresywna (dogmatyczna) - systematyzująca wypowiedzi i wyciągająca z nich szczegółowe wnioski i wyjaśnianie ich znaczenia, oraz metoda genetyczna nazywana też historyczno-ewolucyjną, polegająca na uważnej lekturze miejsc teologicznych w ich porządku historycznym, który jest związany z porządkiem ważności ${ }^{6}$.

\section{Metodyką badań w teologii wizualnej jest bowiem szeroki wachlarz tzw. elementów kulturotwórczych, a więc wszystkie wytwory kultury, które powstają w przestrzeni sztuk plastycznych, rzeźby, filmu, teatru, cybermediach.}

Wszystkie te metody są jednak w jakiejś mierze nieadekwatne w obrębie teologii wizualnej. Metodyką badań $\mathrm{w}$ teologii wizualnej jest bowiem szeroki wachlarz tzw. elementów kulturotwórczych, a więc wszystkie wytwory kultury, które powstają w przestrzeni sztuk plastycznych, rzeźby, filmu, teatru, cybermediach. Dla sformułowania wniosków badawczych można posługiwać się przemiennie metodą analityczną, krytyczną, porównawczą i w dużej mierze syntetyczną. Dzięki połączeniu metod postawiony problem badawczy w sferze kultury zostaje zanalizowany w perspektywie teologii bądź krypto- teologii, ale także w świetle pojęć kulturowych nacechowanych miejscami teologicznymi, tzw. loci theologici. Doświadczenie i obcowanie z dziełami kultury powoduje konieczność

${ }^{6}$ T. Dzidek, Ł. Kamykowski, A. Napiórkowski, Poznanie teologiczne, Kraków 2006, s. 156. 
wprowadzenia jako pomocy badawczej pewnych konstrukcji myślowych, tzw. modeli myślenia, które posłużą do interpretacji określonego zjawiska lub serii zjawisk. Modele nie są opisem rzeczy ani zdarzeń, ale prowizorycznymi i hipotetycznymi schematami, teoretycznymi konstrukcjami, które uczynią zrozumiałymi zjawiska kultury i specyficzne horyzonty kultury.

\section{A. Metoda antropologiczna Karla Rahnera}

Metodą współcześnie stosowaną, pozostającą w nurcie tzw. teologii egzystencjalnej, jest metoda antropologiczna K. Rahnera, pozostającego pod wpływem myśli filozoficznej Kartezjusza i Kanta, gdzie człowiek stał się centrum refleksji i rozumienia świata. Wiara we wcielenie Boga prowadzi w niej do teologicznego antropocentryzmu, czyli do zrozumienia orędzia zbawczego poprzez zbadanie tego, kim jest człowiek i co dla niego znaczy owo zbawienie. Antropologia jawi się w tej metodzie nie tylko jako stałe założenie, lecz także jako wewnętrzny moment samej teologii. Zagadnienie teologiczne jest dopiero wtedy filozoficznie dobrze rozwinięte, gdy odnosi się jednocześnie do przedmiotu materialnego (treści wiary), jak i podmiotu poznającego (człowieka).

Według K. Rahnera metoda ta składa się z trzech faz:

- opisu fenomenologicznego, będącego generalnie ukazaniem naszego doświadczenia np. w przestrzeni wiary;

- redukcji transcendentalnej, która jest odkryciem subiektywnych i apriorycznych (uprzednio ugruntowanych) warunków naszego doświadczenia umożliwiającego nieustanne dążenie do kształtowania wiary;

- dedukcji transcendentalnej, która pozwala odkryć obiektywne warunki rzeczywistości, która jest nam dana subiektywnie w doświadczeniu.

O swojej metodzie teologicznej ${ }^{8}$ sam Rahner pisał tak: „Transcendentalny sposób stawiania pytania, niezależnie od obszaru przedmiotów, w którym występuje, ma miejsce wtedy, gdy i na ile postawione zostanie pytanie o warunki możliwości poznania określonego przedmiotu, istniejące w samym podmiocie poznającym [...] Transcendentalny sposób stawiania pytania jest poprzez to nie tylko dodatkowym pytaniem w stosunku do pytania o pierwotnie i aposterioryczno-empirycznie występujący przedmiot, lecz dopiero w takim sposobie stawiania

${ }^{7}$ Tamże, s. 151-156.

${ }^{8}$ I. Bokwa, Wprowadzenie do teologii Karla Rahnera, Tarnów 1966.

KULTURA - MEDIA - TEOLOGIA 40/2020 
pytań poznanie pierwotnego przedmiotu osiąga swoją pełną istotę. Poznanie samego siebie przez poznający podmiot jest zawsze także poznaniem metafizycznych (w sensie obiektywnym transcendentalnych) struktur samego przedmiotu"9.

\section{B. Metoda estetyczna Hansa Unsa Von Balthasara}

Balthasar nazywał ją teologiczną estetyką, wychodząc z założenia, że Słowo Boga - Logos - objawia się jako łaska, czyli niczym niezasłużony dar Boga. W tym darze Bóg ukazuje się jako piękno niezmienne i wciąż aktualne. Przy czym kwestia piękna w Objawieniu ściśle związana jest z biblijną koncepcją chwały. Termin grecki - doxa, przetłumaczony na język łaciński jako gloria, ma swoje źródło w hebrajskim kabod, co w polskim tłumaczeniu oznacza chwałę (wspaniałość). Chwała wyraża się w kenozie Chrystusa, tj. ogołoceniu i wyniszczeniu, aż po męczeńską śmierć, więc nie jest ani łatwa, ani przyjemna. Tym niemniej wyraża piękno Boga, które człowiek jest zdolny dostrzec i poznać niezależnie od historycznych uwarunkowań, w jakich żyje. Co więcej, człowiek nie może przejść obojętnie wobec tak rozumianego piękna - może się jedynie nim zachwycić, co przynależy do sfery estetycznej. Stąd metoda zwana jest estetyczną: właśnie poprzez spotkanie z pięknem budzi się w człowieku wiara i opanowuje go pragnienie miłości Jezu$\mathrm{sa}^{10}$. W spotkaniu z pięknem człowiek dokonuje wyboru w sposób wolny i nie potrzebuje żadnych argumentów filozoficznych czy antropologicznych. Teologia bowiem nie jest abstrakcyjną refleksją, ale ma prowadzić do spotkania z Bogiem. Celem tak rozumianej teologii jest ukazanie miłości Boga, która szuka odwzajemnienia, a do której dochodzi się poprzez zachwyt nad pięknem, oczarowanie Bogiem, który jest Piękny. Teologiczna estetyka - zdaniem Balthasara - ma bronić teologii przed zakusami racjonalizmu, który w refleksji teologicznej wyrządził wystarczająco dużo szkód. Widać to choćby w teologii dogmatycznej, podzielonej na tak zwane "traktaty”, przez co pierwotne piękno objawiającego się w Jezusie Chrystusie Boga uległo zniszczeniu. Teologiczna estetyka to najdoskonalsza synteza teologicznej metody Hansa Ursa von Balthasara. Określa ją on mianem teologii fundamentalnej, czyli „nauki o postrzeganiu” (Erblickungslehre), natomiast teologia dogmatyczna to dla niego „nauka o zachwyceniu” (Entrückungslehre), utożsamiona z teodramatyką, a więc nauką o Bożym działaniu (gr. dromena)

\footnotetext{
${ }^{9}$ K. Rahner, Schriften zur Theologie, Einsiedeln 1970, s. 98.

${ }^{10}$ H. U. Von Balthasar, Chwała. Estetyka teologiczna 3/2 Teologia. Cz. I, Kraków 2000, s. 67.
} 
w świecie. Teologia fundamentalna i dogmatyczna stanowią razem „teologiczną estetykę". Zdaniem Ignacego Bokwy punktem wyjścia teologicznej estetyki jest podmiotowa oczywistość, wyrażana w postaci estetyki chrystologicznej, a więc kontemplacji postaci Jezusa Chrystusa. Tylko Jezus Chrystus jest widzialnym znakiem niewidzialnej chwały Bożej, która w paradoksalny sposób objawiła się przez krzyż. Bokwa pisze „(...) teologiczna estetyka to odmiana aprioryzmu: Historyczne objawienie w Jezusie Chrystusie zostało potraktowane jako fenomenologiczna „postać" (gr. eidos). Punkt wyjścia całej tej metody stanowi ogląd postaci (Schau der Gestalt). Jest to ogląd ostatecznej, syntetyzującej w sobie całą rzeczywistość postaci ogólnej"11.

\section{Metoda kwadratury Paula Evdokimowa}

Paul Evdokimov rozpatruje obraz w kwadraturze metodologicznej: artysta, dzieło, odbiorca, transcendencja. Dla niego to ten czwarty element obiektywizuje poznanie, pozwala przejść od widzianego do zobaczonego i od zobaczonego do wiary. Święty Paweł mówi, że wiara rodzi się z tego, co się słyszy. Teologia podpowiada jednak, iż jest to formuła zwrotna: nie tylko wiara rodzi się z tego, czego się słucha, ale także to, co wysłuchane, rodzi się z wiary. Podobnie dzieje się w dialektyce cudu: nie tylko wiara rodzi się z cudu, ale - przede wszystkim - cud rodzi się z wiary. Także i tutaj należy powiedzieć, iż nie tylko wiara rodzi się z tego, co zobaczone, ale także - a może przede wszystkim - to, co zobaczone, wynika z wiary. Owym czwartym elementem w tym kwadracie hermeneutycznym jest więc wiara. Bez wiary nie ma ikony teologicznie rozumianej. Jest jedynie obraz wykonany określoną techniką i utrzymany w określonych kanonach. Wiarą odbiorca rozpoznaje obecność w ikonie. To właśnie „obecność” stanowi to, co „zobaczone” w ikonie. Nie ma teologii ikony bez teologii oglądającego (widzącego, patrzącego na ikonę). Teologia wizualna w swej istocie nie jest teologią piękna, ani nawet teologią obrazu jako takiego, nie jest teologią tego, co pokazane, ale tego, co zobaczone. Jest teologią patrzącego i światła, które jest konieczne, by z widzenia przejść do zobaczenia. Tym światłem - owym czwartym elementem kwadratu hermeneutycznego - jest wiara, która pozwala przekształcać widzącego (spectans) w tego,

${ }^{11}$ I. Bokwa, Kilka uwag o metodzie teologii wizualnej w nawiq̨zaniu do K. Rahnera (19041988) i H.U.von Balthasara (1905-1988), w: W. Kawecki (red.), Wierzyć i widzieć, dz. cyt., s. 50. 
który zobaczył (videns). To ona pozwala zobaczyć to, co święte tam, gdzie inni zatrzymują się tylko na widzeniu - patrzeniu ${ }^{12}$.

\section{Metoda ikonograficzno-ikonologiczna Erwina Panofskiego}

Chcąc zbadać dzieło metodą Panofsky’ego, należy zadać sobie pytania według schematu „od ogółu do szczegółu”: Co przedstawia dzieło? Kim są przedstawione postaci? Czy możemy je zidentyfikować? Po ustaleniu odpowiedzi na powyższe pytania staramy się dotrzeć do głębszych znaczeń przedstawionych wyobrażeń. Konsekwentnie stosowana metoda Erwina Panofsky'ego - w jej trzech etapach pozwala nie tylko zrozumieć podstawową treść dzieła sztuki, rozszyfrować sekundarne znaczenie zastosowanych w nim tematów i odczytać ich symboliczne znaczenie zmieniające się $w$ kontekście różnych epok, ale nawet wskazać przypadki, gdy dzieło mówi zupełnie coś innego, niż zamierzał wyrazić artysta działający pod wpływem uwarunkowań epoki i jej kultury. Wyniki kolejnych etapów metody ikonologicznej podlegają weryfikacji. Opis przedikonograficzny konfrontowany jest z "historią stylów”, analiza ikonograficzna z „historią typów” (która bada, jak w zmieniających się warunkach historycznych przedstawiano ten sam temat za pomocą różnych obiektów i zdarzeń), a analiza ikonologiczna z „ogólną historią symboli" (dociekającą, jak w zmieniających się warunkach historycznych przestawiano główne tendencje ludzkiego ducha za pomocą określonych tematów). W analizie preikonograficznej (analiza formalna dzieła), w której opisujemy to, co widzimy okiem, a nie umysłem, nie posiłkujemy się nabytą wiedzą, kulturą czy wyznaniem. W analizie preikonograficznej formy muszą być rozpoznane jako motywy (główny element tematyczny), będące nośnikami znaczeń. Istnieją również motywy o znaczeniu abstrakcyjnym (wyrażające), takie jak: atmosfera, nastrój, gest, mimika. Rozpoznanie motywów i znaczeń możliwe jest po prostu jako „znajomość rzeczy i zdarzeń”, uzupełnione o wiedzę źródłową w przypadku, gdy doświadczenie życiowe nie podpowiada znaczenia tematu (np. kostiumy, których dzisiaj się nie używa). Analiza preikonograficzna ma za zadanie rozpoznanie wszystkich występujących w dziele sztuki motywów i ich znaczeń podstawowych. Ten etap ma na celu rozpoznanie wszystkiego, co w dziele sztuki widzimy oczami, a więc obiektów (ludzie, zwierzęta, rośliny, przedmioty, elementy naturalne itp.) oraz zdarzeń (sytuacji), w których uczestniczą te obiekty, oraz

${ }^{12}$ P. Evdokimow, Sztuka ikony. Teologia piękna, tłum. M. Żurowska, Warszawa 1999, s. 126. 
nazwanie tych obiektów i sytuacji, ale tylko w podstawowym zakresie, wynikającym z elementarnego doświadczenia życiowego. Opisując, czym jest obiekt lub sytuacja, odczytujemy jego znaczenie „faktyczne”, zaś opisując wskazując na pewne cechy obiektów lub sytuacji odczytujemy jego znaczenie „wyrażające”. Aby dobrze przeprowadzić analizę preikonograficzną, musimy się „wyzbyć” pewnej wiedzy kulturowej czy religijnej i spojrzeć na dzieło tzw. „nieuprzedzonym okiem”13. Analiza ikonograficzna z kolei to dziedzina badań historii sztuki, której zadaniem jest opis i interpretacja elementów treściowych i symbolicznych w dziełach sztuki. Podstawą analizy ikonograficznej jest wynik poprzedniej analizy preikonograficznej, oraz ogólna wiedza pochodząca najczęściej ze źródeł literackich. Na tej podstawie dokonuje się ustalenie tematu, który odkrywa sekundarne (konwencjonalne) znaczenie dzieła. Zatem analiza ikonograficzna wiąże motyw lub kompozycję, mającą swoje podstawowe, wynikające z doświadczenia życiowego znaczenie, z sekundarnym znaczeniem symbolicznym, wynikającym z wiedzy nabytej w ramach konkretnej kultury. Analiza ikonograficzna ma więc charakter zawężający, bo odkrywa znaczenia czytelne tylko w ramach jednej kultury. W ten sposób człowiek nieznający tradycji chrześcijańskiej nigdy nie domyśli się nawet istnienia całego „ciągu dalszego”, jaki związany jest np. z postacią Jezusa poddanego chrztowi w rzece Jordan. Następny etap omawianej metody, analiza ikonologiczna, wyjaśnia sens przedstawienia, zadaje pytanie, co wiemy o danym dziele? Jaki jest czas i miejsce jego powstania? Jaki jest styl, kto jest autorem, itp. Formy, motywy i tematy traktowane są w dwóch pierwszych etapach jako właściwości i cechy samego dzieła sztuki. W analizie ikonologicznej nabierają one charakteru wartości symbolicznych, zbudowanych na narodowej, epokowej, religijnej i filozoficznej podstawie. Uwzględnienie zatem podłoża, z jakiego wyrasta wartość symboliczna, nadaje dziełu szerszy kontekst, który jest istotą ikonologii. Można powiedzieć, że ikonografia widzi tylko dzieło, ikonologia zaś widzi je zawieszone w kulturowej przestrzeni. W tym znaczeniu dzieło staje się świadectwem swoich czasów, albo preferencji artysty i/lub zleceniodawcy. Istotne jest również to, że analiza ikonologiczna ustawia dzieło w szeregu i w kontekście innych dzieł sztuki tego samego oraz innych artystów. Typowe pytania, jakie formułuje Panofsky, brzmią: Dlaczego konkretny artysta stosuje wielokrotnie ten sam motyw w wielu dziełach? Dlaczego w wielu dziełach różnych artystów tworzących w tej samej

${ }^{13}$ E. Panofsky, Warstwy znaczeniowe dzieła sztuki, Warszawa 1971, s. 20. 
epoce pojawiają się te same tematy? Według Panofsky'ego podstawą analizy ikonologicznej jest „intuicja syntetyzująca”, rozumiana jako „obycie z głównymi tendencjami ludzkiego ducha".

\section{E. Metoda hermeneutyki teologicznej}

Zdaniem Marii Janion „(...) hermeneutyka jest - mówiąc najogólniej - objaśnieniem tradycji, tłumaczeniem jej przekazów, jej tekstów. Pojawia się ona wtedy (...), kiedy tradycja traci swą niedyskursywną, magiczną niepodzielność i nieoczywistość, kiedy domaga się interpretacji, kiedy przede wszystkim dochodzi do racjonalizacji i ufilozoficznienia religii"14. Hermeneutyka poszukuje reguł rozumienia, ale one nigdy nie są wystarczające, gdyż to, co tekst kulturowy mówi, zależy od wrażliwości odbiorcy. W rozumieniu podkreśla się element twórczej, a nie jedynie odtwórczej interpretacji. „Każde dzieło sztuki domaga się interpretacji, a każda interpretacja domaga się oceny jej warunków, do których zalicza się nasze spojrzenie oraz nasze interpretacyjne możliwości i ograniczenia. Te zdolności interpretacyjne są z kolei same w sobie uwarunkowane z jednej strony przez nasze indywidualne biografie i wszystkie czynniki, które się na nie składają, a z drugiej strony przez obecną sytuację, w jakiej się znajdujemy i w jakiej działamy"15. Potwierdza to Karol Klauza w swojej monografii „Teologiczna hermeneutyka ikony", która jest rozprawą teologiczną z zakresu metodologii, traktującą ikonę jako źródło dla interpretacji i historii dogmatu ${ }^{16}$. Hermeneutyka uzasadnia wielość interpretacji i możliwość ich odczytywania przez każdego człowieka z wytworów kulturowych, w tym przypadku obrazów religijnych. Dzieje się tak dlatego, że wymowa obrazu religijnego jest specyficzna ze względu na jego symboliczny język. Symbol, będąc znakiem wieloznacznym, określa więcej niż zazwyczaj znaczy, wskazuje na coś poza sobą. Nie mówi tylko o rzeczywistości, która się wydarzyła, nie mówi tylko o losie jednostki, ale również o losie i sprawach każdego człowieka. Jeżeli zaś to odczytywanie zostanie połączone z obiektywnymi normami interpretacyjnymi treści religijnych (m.in. uwzględnienie żywej Tradycji, nauczania Kościoła i analogii wiary, szukanie sensu wynikającego z celu przesłania,

${ }^{14}$ M. Janion, Hermeneutyka, w: M. Janion (red.), Humanistyka: poznanie i terapia, Warszawa 1982 , s. $123-124$.

${ }^{15}$ W. Jeanrond, Hermeneutyka teologiczna, Kraków 1999, s. 15-16.

${ }^{16}$ K. Klauza, Teologiczna hermeneutyka ikony, Lublin 2000. 
jakim jest przekaz prawd pożytecznych dla zbawienia) oraz normami właściwymi dla danego dzieła malarskiego jako dzieła sztuki, to zwiększa się szansa jego poprawnego odczytania. Hermeneutyka zajmuje się zatem procesem rozumienia, interpretacji dzieła, bada obraz z perspektywy odbiorcy. Obraz powstał po to, by powiedzieć coś konkretnym odbiorcom i był tworzony tak, by odbiorca mógł go „odczytać”. Obraz wobec tego wymaga od odbiorców pewnych kompetencji, intuicji, by możliwa stała się jego interpretacja. Sama intencja autora nie jest jednak warunkiem koniecznym do zrozumienia obrazu. Obraz w momencie ukończenia traci w pewnym sensie swą zależność od autora. Poprzez kolejne wieki dociera do różnych odbiorców i jest interpretowany na różne sposoby, niekiedy zupełnie odmienne od tych, w których pojmował go autor. Może przekazywać swoje przesłanie na podstawie własnego potencjału komunikacyjnego, który nie zależy od pierwotnych okoliczności ${ }^{17}$. W związku z tym interpretacja obrazów jest czymś znacznie więcej niż poszukiwaniem ukrytych znaczeń. Z kolei kompetencja odbiorców będzie zawsze zależna od ich własnego kontekstu kulturowego, egzystencjalnego, politycznego, społecznego, religijnego. Hermeneutyka jest zafascynowana tym, jak te dzieła są rozumiane i czy możliwe jest pełne rozumienie dzieła sztuki, dlatego próbuje opisać warunki właściwego rozumienia. Inaczej mówiąc, stawia się tu pytanie, na jakich warunkach określony akt interpretacji można nazwać poprawnym ${ }^{18}$. Hermeneutyka zastanawia się nad tym, w jaki sposób w trakcie odbioru dzieła, obraz ujawnia odbiorcy swój potencjał komunikacyjny.

\section{ZOBACZYĆ, ABY UWIERZYĆ (FIDES EX VISU)}

Współzależność wiary i sztuki była w historii wielokrotnie marginalizowana. Współcześnie jednak, a to za sprawą teologów, żeby wymienić tylko niektórych P. Tillicha, H. U. von Balthasara, Y. Congara, H. de Lubaca, K. Rahnera, B. Chenu, K. Wojtyły, J. Ratzingera, P. Pouparda, G. Ravasiego. P. Evdokimova, W. Kaspera, T. Spidlika, M.I. Rupnika, Th. Verdona, a na polskim gruncie J. Szymika, J. Królikowskiego, A. Draguły, M. Lisa, - coraz częściej jest dowartościowywana i na nowo odkrywana. W obecnej dobie możemy się spotkać z formułą analogiczną do pawłowego sformułowania fides ex auditu, a mianowicie fides ex visu czy

${ }^{17}$ W. Jeanrond, Hermeneutyka teologiczna, dz. cyt., s. 103.

${ }^{18}$ E. D. Hirsch, Validity in Interpretation, New Haven-London 1967, s. 180. 
theologia ex visu, akcentującą rolę obrazu w teologicznym poznaniu. Fides ex visu oznacza, że wiara rodzi się z tego, co zobaczone, ale także to, co zobaczone, może wynikać z wiary. Obok artysty, dzieła, odbiorcy, potrzebna jest jeszcze wiara. Wiara, która jak każda idea żyje w doświadczeniu, między innymi doświadczeniu artystycznym. Bez niej nie jesteśmy w stanie zrozumieć dogłębnie jakiegokolwiek obrazu, a każda ikona malarska, filmowa, telewizyjna pozostanie jedynie zwykłym obrazem wykonanym określoną techniką i utrzymaną w określonych kanonach, szkołach, gatunkach. To dzięki wierze odbiorca rozpoznaje obecność Boga w obrazie, ale i vice versa: dzięki obrazom może on wzmocnić swoją wiarę. Stanie się wszakże tak tylko wtedy, gdy święte wizerunki nie będą głównie dostarczać nam przyjemności estetycznej, ale wprowadzą nas w misterium. Jeśli aspekt estetyczny stałby się dominującym, wówczas obraz przejąłby funkcję tematu artystycznego, a nie nośnika przekazu duchowego. A zatem wiara i doświadczenie wizualne różnego rodzaju sztuk mogą być postrzegane we wzajemnej zależności i we wzajemnym oddziaływaniu. Wiara nie tylko posługuje się obrazem, komunikuje się poprzez obraz, ale także kształtuje się przy pomocy formy artystycznej w licznych swoich epifaniach. Natomiast doświadczenie artystyczne nie tylko jest zewnętrznym nośnikiem wiary chrześcijańskiej, ale kształtuje się jako wiara, jako moment i forma wiary chrześcijańskiej historycznie usytuowanej. Innymi słowy - sztuka może uczyć wiary i może być świadectwem wiary. Nie należy jednak zapominać, że wiara jest aktem, który urzeczywistnia się przez słuchanie Słowa, a potem przez Jego oglądanie, bo Słowo uczyniło się także widzialnym. Z pewnością istnieją napięcia między obrazem a słowem, ale przecież jedno nie wyklucza drugiego, a można nawet powiedzieć, że jedno drugie dopełnia. Teologiczna estetyka bazująca na obrazach jest w stanie obronić się przed zakusami racjonalizmu, szpetoty, brutalizacji sztuki, deformacji kultury wizualnej ulegającej różnego rodzaju symulakrom i wirtualizacji rzeczywistości, o ile będzie zdolna skupić się na człowieku, jego uzdolnieniach, na prawdzie kondycji ludzkiej, a także o ile usytuuje w swym centrum Jezusa Chrystusa. Czy wiara będąc wewnętrznym stanem człowieka, osobowym przylgnięciem człowieka do Boga, uznaniem całej prawdy, którą On objawił, jest możliwa do przekazania-komunikacji za pomocą obrazu (malarskiego, filmowego, telewizyjnego, reklamowego), ale także obrazowania mającego swe miejsce w architekturze? Odpowiedź na to pytanie implikuje przyjęcie istnienia i funkcjonowania teologii wizualnej. To ona właśnie jest w stanie dotykać tajników rzeczywistości osoby i rozpoznawania przez nią 
Boga. Rozpoznając Boga w materii poprzez symbol - znak - obraz, wierzący może zrozumieć nową godność każdej rzeczy materialnej, a w niej sztuki wizualnej, zdolnych poprowadzić go do świata duchowego i eschatologicznego, a w konsekwencji do doświadczenia wiary. Wcielenie, jak wcześniej wykazywałem, było wizualizacją Boga, wejściem Boga w konkret ludzkiej egzystencji oraz w widzialność materialnego świata. Poprzez obraz jesteśmy zatem w stanie zrozumieć Bożą rzeczywistość niekiedy o wiele bardziej niźli przez słowo, a to oznacza, że staje się on środkiem komunikacji Boga z człowiekiem, a jednocześnie środkiem przekazywania informacji o Bogu, wierze, Kościele. To zadanie podejmuje teologia wizualna, używając języka symbolicznego, ,języka obrazowego", pozwalającego trudne niekiedy prawdy wiary wyrażać w zrozumiały dla ludzi sposób. Posługuje się ona także językiem mediów, który - choć nie zawsze jest kompatybilny z językiem chrześcijańskim - to jednak pomaga nam odkrywać prawdę o człowieku. Teologia wizualna posługująca się symbolem jako „strukturą teologiczną” może rzeczywiście być drogą, która pozwoli połączyć treści wiary ze sposobem ich przekazywania. Z całą pewnością sztuki wizualne są wyzwaniem dla współczesnych teologów nawet wtedy, gdy powstają dzieła obrazujące zwątpienie towarzyszące współczesnemu człowiekowi. Nowe media i cała paleta sztuk wizualnych nie jest i nie może być terenem zastrzeżonym dla profanum, niedostępnym bastionem dla wiary. W nich także odnajdujemy miejsca teologiczne, dzięki którym lepiej można zrozumieć historię człowieka poszukującego Boga, gdyż doświadczenie religijne nie jest wyłącznie domeną miejsca świętego. Uprawianie teologii poprzez sztukę i to nie tylko tę sakralną, ma więc swoje uzasadnienie, a w sztukach wizualnych teologia staje się ucieleśnioną, bo osadzoną w tym, co materialne. Sztuka wizualna w takim ujęciu staje się partnerką teologii w odwoływaniu się do wartości, do piękna, do nieustannie poszukiwanej transcendencji. Zobaczyć Boga można między innymi we wzajemnej relacji piękna, rozumu i wiary, czyli właściwie rozumianej teologicznej estetyce. Sztuki wizualne nie muszą być zagrożeniem dla wiary, przeciwnie, mogą stawać się, jak to trafnie wyraził J. Ratzinger, apologią chrześcijaństwa, sprawiając, że „Bóg staje się nam bliższy”. Można zatem powiedzieć, że każda autentyczna sztuka, a sztuka wizualna przez swoją moc perswazji szczególnie, jest darem, jaki człowiek otrzymał od Boga. 


\section{BIBLIOGRAFIA}

Balthasar H.U., Chwała. Estetyka teologiczna 3/2, Teologia. Cz. I, Kraków 2010.

Bokwa I., Wprowadzenie do teologii Karla Rahnera, Tarnów 1966.

Bokwa I., Kilka uwag o metodzie teologii wizualnej w nawiq̨zaniu do K. Rahnera (19041988) i H.U.von Balthasara (1905-1988), W: W. Kawecki (red.) Wierzyć i widzieć, Sandomierz 2013, s. 47-53.

Chenu B., Disciples d'Emmaus, Paris 2003.

Draguła A., Teologia wizualna. Kwadrat hermeneutyczny (artysta, dzieło, odbiorca, wiara), w: W. Kawecki (red.) Wierzyć i widzieć, Sandomierz 2013, s. 13-29.

Dzidek T., Kamykowski Ł., Napiórkowski A., Poznanie teologiczne, Kraków 2006.

Evdokimov P., Sztuka ikony. Teologia piękna, tłum. M. Żurowska, Warszawa 1999.

Hirsch E.D., Validity in Interpretation, New Haven-London 1967.

Jan Paweł II, Kościół potrzebuje sztuki, w: Jan Paweł II. Nauczania Papieskie, III, 2, Poznań-Warszawa 1980, s. 694-699.

Janion M., Hermeneutyka, w: M. Janion (red.), Humanistyka: poznanie i terapia, Warszawa 1982, s. $120-134$.

Jeanrond W., Hermeneutyka teologiczna, Kraków 1999.

Klauza K., Teologiczna hermeneutyka ikony, Lublin 2000.

Mitchell W.J.T., Pokazać widzenie, w: I. Kurz, P. Kwiatkowska, Ł. Zaremba (red.) Antropologia kultury wizualnej. Zagadnienia i wybór tekstów, tłum. Ł. Zaremba, Warszawa 2012, s. 45-62.

Neipp B., Apporto dell'imagine al testo biblico dalla prassi nella Chiesa all'approcio scientifico. W: E. Genre, Y. Redalie' (red.) Arte e teologia, Torino 1997, s. 91-98.

Panofsky E., Warstwy znaczeniowe dzieła sztuki, Warszawa 1971.

Rahner K., Schriften zur Theologie, Einsiedeln, 1970.

\section{Biogram}

Ks. prof. Witold Kawecki - profesor nauk teologicznych w zakresie teologii kultury i mediów, kierownik Zakładu Teologii Ewangelizacji Medialnej (2002-2005), twórca specjalności teologii kultury, organizator i dyrektor Instytutu Wiedzy o Kulturze UKSW (2009-213), współorganizator specjalności komunikacji medialno-kulturowej na kierunku dziennikarstwo, kierownik katedry „Dialogu Wiary z Kulturą”; Wykładowca Instytutu Edukacji Medialnej i Dziennikarstwa oraz Instytutu Socjologii UKSW (2002-2005), WSD Redemptorystów w Tuchowie i WSD Kapucynów w Krakowie (1999-2002); w latach 1997-2002 redaktor naczelny „Homo Dei” oraz dyrektor wydawnictwa Homo Dei w Krakowie, współzałożyciel grupy wydawniczej ORDO; współzałożyciel pisma naukowego Kultura-Media-Teologia, rekolekcjonista w Polsce i za granicą (ponad 200 prac). Autor 30 książek i kilkuset tekstów pisanych. Tłumacz z francuskiego, włoskiego i hiszpańskiego. Uczestnik kilkuset programów radiowo-telewizyjnych. Współpracownik Polskiego Radia, Telewizji Polskiej i innych mediów. Członek Stowarzyszenia Dziennikarzy Katolickich, 
Stowarzyszenia Teologów Moralistów Polskich, Polskiego Towarzystwa Kulturoznawczego, Polskiego Stowarzyszenia Komunikacji Społecznej, Międzynarodowego Stowarzyszenia Filmowego „Signis”. Nagrodzony m.in. Feniksem za książkę „Sztuka polska a Kościół dzisiaj". Przewodniczący Zespołu Kompetencji Kulturowych Kościoła przy Narodowym Centrum Kultury. Ekspert w zakresie teologii i kulturoznawstwa Polskiej Komisji Akredytacyjnej. Zajmuje się teologią kultury, teologią moralną, teologią piękna, medioznawstwem, kulturą polityczną i katolicką nauką społeczną.

ORCID: 0000-0002-8074-5859 


\title{
Jacek Kiciński CMF
}

\author{
Papieski Wydział Teologiczny we Wrocławiu
}

\section{Świętość w ujęciu papieża Franciszka}

\section{Holiness according to Pope Francis}

\begin{abstract}
ABSTRAKT
Powołanie do świętości jest szczególnym zaproszeniem do udziału w komunii

z Bogiem. Papież Franciszek jako następca na Stolicy Piotrowej zaprasza wszystkich na drogę świętości. Pokazuje, że świętość jest dla każdego. Niniejsze opracowanie ma na celu ukazanie świętości w perspektywie nauczania

Ojca Świętego Franciszka. Według niego świętość realizowana jest w codzienności. Szczególnym wyrazem świętości są Chrystusowe błogosławieństwa. Na tej drodze nie może zabraknąć zaufania, czuwania i rozeznawania woli Bożej. Dla Papieża świętość to obecność. W tej obecności ważne miejsce zajmuje Maryja.

SŁOWA KLUCZOWE:

świętość, droga, obecność, rozeznawanie, czuwanie
\end{abstract}

\begin{abstract}
A calling to holiness is a very special invitation to participating in communion with God. Pope Francis, a successor of Saint Peter, invites each and everyone to the path of holiness. He shows that holiness is for everyone. The purpose of this study is to show holiness from the perspective of the Holy Father Pope Francis. According to him, holiness is realized in the every day. An expression of holiness are in particular Christ's graces. The path of holiness is full of trust, staying awake and discernment of God's Will. For Pope Francis holiness means presence. In this presence Holy Mary plays an important part.
\end{abstract}

\section{KEYWORDS:}

holiness, the journey, presence, discernment, alertness

\section{WPROWADZENIE}

Ojciec Święty Franciszek od chwili rozpoczęcia swojego pontyfikatu pragnie przybliżyć Chrystusa współczesnemu człowiekowi. Czyni to przede wszystkim poprzez osobiste świadectwo życia. W ten sposób daje odpowiedź na jawiący się głód obecności i bliskości. Dzisiejszy człowiek, zatopiony w kulturze doczesności, utracił w pewien sposób wrażliwość na potrzeby innych, czyniąc siebie centrum własnego życia. W ten sposób powstał nowy, bardzo niebezpieczny sposób życia 
określany mianem tymczasowości, a jego owocem jest życie na tzw. próbę. Owocem tego jest zanikanie poczucia odpowiedzialności za drugiego i brak postawy wierności wobec podjętych decyzji. To wszystko dokonuje się w oderwaniu od Boga i Jego przykazań. Dziś w wielu obszarach życia nie tylko nie uznaje się istnienia Boga, ale pojawia się coś zupełnie zatrważającego - Bóg staje się człowiekowi niepotrzebny. Stąd też, Chrystusowe wołanie o świętość jest coraz głośniejsze w dzisiejszym świecie. Papież Franciszek, zdając sobie sprawę, że tylko święci mogą zmienić oblicze tej ziemi, przypomina całemu światu, że każdy powołany jest do świętości ${ }^{1}$.

\section{DZISIEJSZY ŚWIAT I WSPÓłCZESNY CZŁOWIEK}

Charakteryzując dzisiejszy świat, papież Franciszek ukazuje go za pomocą metafory supermarketu. W opartym na jego nauczaniu przesłaniu do osób konsekrowanych Głoście czytamy, że cechą charakterystyczną naszych czasów jest proces głębokiej i ciągłej przemiany, której znamiona trudno określić ${ }^{2}$ Jesteśmy zatem świadkami mnożących się wizji życia, które bardzo często stawiane są na tym samym poziomie. Działanie to sprawia, że wartość każdej z nich zostaje zrelatywizowana, a w końcu pomniejszona. Owocem tego jest zmieniający się sposób postrzegania osoby, rodziny, przyjaźni, miłości, pracy, obowiązku, czy też samego podejścia do procesu umierania ${ }^{3}$. Ponadto, postępujący pluralizm etniczno-kulturowy sprawia, że współczesny człowiek szybko przechodzi przez wiele życiowych doświadczeń z ofertą tzw. nieokreślonych możliwości. Życie staje się podobne do supermarketu, w którym oferuje się nie tylko rzeczy, ale także okazje, idee, postawy, które wręcz zmuszają człowieka do wybierania i samookreślenia się. W ten sposób zmienia się poczucie granic, które sprawia, że człowiek nie czuje żadnych barier, jakie normalnie określają i precyzują pragnienia i działania. Powoduje to szybko rozwijający się indywidualizm, przesadne akcentowanie własnego ,ja”. Relacje miedzyludzkie stają się niestabilne, zmienne, niekiedy wręcz

${ }^{1}$ Kongregacja do spraw Instytutów Życia Konsekrowanego i Stowarzyszeń Życia Apostolskiego, Głoście. Do osób konsekrowanych, świadków Ewangelii wśród narodów, Warszawa 2014, nr 38-41 [dalej skrót: Głoście].

${ }^{2}$ Zob. Franciszek, D. Wolton, Otwieranie drzwi. Rozmowy o Kościele i świecie, przeł. M. Chojnacki, Kraków 2018, s. 129-171.

${ }^{3}$ Por. Franciszek, Głoście, nr 3. 
bliżej nieokreślone, zwłaszcza w chwilach podejmowania życiowych decyzji. Wiąże się z tym brak odpowiedzialności za drugiego człowieka oraz wrażliwości na jego codzienne potrzeby ${ }^{4}$.

Mając na uwadze postępujący proces kulturowy, jesteśmy świadkami tego, jak wchodząca w życie nowoczesność łamie zasady powszechnego uniwersalizmu, postrzegając samą siebie jako płynny postmodernizm. W konsekwencji dzisiejszy człowiek staje w poczuciu niespełnienia i niepewności. Brak stałości emocjonalnej i nietrwałość relacji sprawiają, że mamy do czynienia z sytuacją, w której nie jest on w stanie wypracować własnego stylu życia gwarantującego mu szczęście i konsekwentne podążanie w wyznaczonym kierunku. Ta złożoność dzisiejszych czasów powoduje, że zapomina się o postawie słuchania, zwłaszcza ludzkiego krzyku cierpienia, a także o słuchaniu Boga i duchowym znaczeniu Ewangelii ${ }^{5}$. W tym wszystkim łatwo zauważyć proces postępującej sekularyzacji, który przyczynia się do sprowadzenia wiary do przestrzeni czysto prywatnej i wewnętrznej. Negacja zaś wszelkich odniesień do transcendencji powoduje deformację etyczną, osłabienie poczucia grzechu osobistego i społecznego oraz stopniowy wzrost moralnego relatywizmu. W konsekwencji pojawia się ogólna dezorientacja, zagubienie duchowe, zwłaszcza u ludzi młodych. Oni bowiem są najbardziej narażeni na różne zranienia, których konsekwencje mogą odbijać się na całym ich życiư ${ }^{6}$.

Mówiąc o dzisiejszym świecie, należy także dodać, że rodzina, która jest fundamentem życia społecznego, przechodzi głęboki kryzys kulturowy. Jak zaznacza papież Franciszek, „kruchość więzi staje się szczególnie poważna, ponieważ chodzi o podstawową komórkę społeczeństwa, o miejsce, gdzie człowiek uczy się współżycia w różnorodności i przynależności do innych i gdzie rodzice przekazują dzieciom wiarę. Istnieje skłonność, by widzieć małżeństwo jako czystą formę uczuciowej gratyfikacji, którą można ustanowić w jakikolwiek sposób oraz zmienić zależnie od wrażliwości każdego"7.

Przedstawione obszary życia stanowią wielkie wyzwanie dla ewangelicznej działalności Kościoła. Stąd też, każdy z omówionych wymiarów życia ludzkiego

${ }^{4}$ Por. tamże.

${ }^{5}$ Por. tamże, nr 4.

${ }^{6}$ Por. Franciszek, Evangelii gaudium. Adhortacja apostolska o głoszeniu Ewangelii we współczesnym świecie, Kraków 2014, nr 64 [dalej skrót: EG].

${ }^{7}$ Tamże, nr 66. 
domaga się konkretnych odpowiedzi w duchu Ewangelii. Papież Franciszek, mając świadomość złożoności ludzkich problemów, mówi do całego Kościoła powszechnego, że trzeba wstać z kanapy wygodnego życia i z całym entuzjazmem podjąć wezwanie do świętości ${ }^{8}$.

\section{KOŚCIÓŁ W DRODZE - BYĆ UCZNIEM-MISJONARZEM}

Ojciec Święty Franciszek, idąc za św. Janem Pawłem II zaznacza, że przejawem autentycznego życia ucznia-misjonarza Chrystusa jest radość wewnętrzna płynąca z wiary. Zwłaszcza w dzisiejszym świecie, udręczonym i przytłoczonym rozmaitymi problemami prowadzącymi niekiedy do postawy pesymizmu, głoszący Ewangelię winien być człowiekiem, który w Chrystusie odnajduje radość i nadzieję? Dlatego proklamacja słowa Bożego winna być połączona ze świadectwem życia i w ten sposób stać się jego pasją. Stąd też papież Franciszek zachęca wszystkich wiernych, by nie byli smutnymi ewangelizatorami, z grobowq minq, i bojaźliwymi. Trzeba bowiem dziś przekazywać wiarę, która jest radością życia ${ }^{10}$.

Wobec zaistniałej sytuacji należy stawiać sobie bardzo ważne pytania dotyczące głoszenia słowa Bożego, a także oczekiwań dotyczących Boga i współczesnej ludzkości ${ }^{11}$. W odpowiedzi na te pytania papież Franciszek stwierdza, że obecne czasy wzywają nas do tworzenia sensownych projektów, dzięki którym kultura nowego humanizmu chrześcijańskiego będzie mogła wzbudzić - w nietrwałej płynności i w trudnej do opanowania złożoności postępu technicznego zdolność do nadania znaczenia egzystencji oraz stworzyć horyzont wzajemnej komunikacji, zrozumienia i odniesień do wartości. Światło Ewangelii może ponownie zachwycić świat poprzez możliwość rozpoczęcia wędrówki ku prawdzie. Potrzeba jednak odnowionego głoszenia Dobrej Nowiny ${ }^{12}$.

Ojciec Święty przypomina całemu Kościołowi, że w każdym człowieku ochrzczonym działa uświęcająca moc Ducha Świętego, która skłania go do ewangelizowania. Ponadto, Bóg w swojej nieskończonej miłości obdarza całość wiernych instynktem wiary - sensus fidei, który wspomaga ich w rozeznawaniu tego, co od Niego pochodzi. Stąd też wszyscy chrześcijanie niezależnie od pełnionej posługi w Kościele stają się uczniami-misjonarzami Jezusa Chrystusa. Potrzebujemy więc nieustannej ewangelizacji swego serca, a z drugiej strony jesteśmy posłani, 
by świadczyć o Królestwie Bożym ${ }^{13}$. Nikt zatem nie powinien wyrzekać się swojego udziału w ewangelizacji świata. Jeśli bowiem ktoś doświadczył miłości Boga, nie potrzebuje zbyt wiele czasu, by tą miłością dzielić się z innymi. Dlatego, jak zaznacza Ojciec Święty, „każdy jest misjonarzem w takiej mierze, w jakiej spotkał się z miłością Boga w Chrystusie Jezusie. Nie mówmy już więcej, że jesteśmy uczniami i misjonarzami, ale zawsze jesteśmy uczniami-misjonarzami"14. Zdanie to jest niezwykle ważne dla zrozumienia powołania do świętości. Wiele osób niekiedy rozdziela te dwie rzeczywistości, podkreślając, że najpierw jest czas uczenia się, a potem głoszenia. Franciszek uświadamia nam, że spotkanie z miłością sprawia, że człowiek pragnie ją poznawać i nią się dzielić. Zatem, wejście w przestrzeń bycia uczniem Jezusa zakłada jednocześnie uczestnictwo w Jego misji głoszenia i świadczenia o Dobrej Nowinie.

Mając na uwadze wskazania papieża Franciszka odnośnie do głoszenia Ewangelii w drodze, zauważamy, że Ojciec Święty przypomina o osobistym i wspólnotowym zaangażowaniu. Jest to droga Kościoła, w której uczestniczą wszyscy i nikt z tej drogi nie jest wykluczony. Dlatego zachęca, aby każdy wierzący podjął wysiłek świadczenia o Chrystusie. Jest to - według Papieża - nasze codzienne zadanie. Chodzi tu przede wszystkim o niesienie Ewangelii tym, z którymi mamy do czynienia na co dzień. Są to zarówno nasi najbliżsi, jak i ci, z którymi żyjemy, pracujemy i spotykamy się, a nawet osoby, których nie znamy. Jest to, jak zaznacza Franciszek, nieformalne przepowiadanie Słowa, które może się urzeczywistniać podczas rozmowy czy innych okazjonalnych spotkań. Dlatego być uczniem-misjonarzem oznacza być zawsze gotowym, aby nieść miłość Jezusa ${ }^{15}$.

Każde zatem spotkanie jest okazją do świadczenia o Bogu i Jego Królestwie. Winno być ono naznaczone pełnym szacunkiem i uprzejmością wobec drugiego człowieka. Dopiero w takiej atmosferze szacunku i dialogu osobistego, gdzie druga osoba dzieli się swoimi radościami, nadziejami i troskami, możliwe jest przedstawienie Słowa. Może to być propozycja lektury fragmentu Pisma Świętego lub opowiadania zawartego w słowie Bożym. Czasem to będzie krótkie spotkanie, innym razem dłuższa rozmowa. Potrzeba w tym wszystkim otwarcia się na światło

\footnotetext{
${ }^{13}$ Por. tamże, nr 119.

${ }^{14}$ Tamże, nr 120.

${ }^{15}$ Por. tamże, nr 127.
} 
Ducha Świętego ${ }^{16}$. Głoszenie słowa Bożego winno stanowić centrum naszego życia. Dlatego papież Franciszek zachęca, abyśmy nigdy nie zniechęcali się i nie ulegali pokusie rozczarowania.

Być Kościołem w drodze, to tworzyć wspólnotę wiary z wiernymi, pasterzami, a nade wszystko z Jego głową, następcą św. Piotra - Papieżem. W tym kontekście Ojciec Święty wskazuje współczesnym na znak czasu, jakim jest osobiste towarzyszenie we wzroście duchowym. Podkreśla to m.in. we wspomnianej adhortacji poświęconej radości głoszenia Ewangelii - Evangelii gaudium. Papież zaznacza tam, że: „we współczesnej cywilizacji zranionej anonimowością, a jednocześnie obsesyjnej na punkcie szczegółów życia innych, bezwstydnie chorej na chorobliwą ciekawość, Kościół potrzebuje bliskiego spojrzenia, by kontemplować, wzruszyć się i zatrzymać wobec drugiego człowieka, ilekroć jest to koniecz-

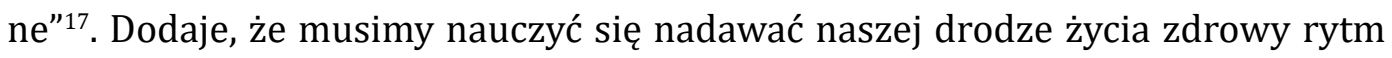
bliskości ze spojrzeniem okazującym szacunek i pełnym współczucia. Wszystko to ma prowadzić do wewnętrznego uzdrowienia, dojrzewania i osiągania pełni życia chrześcijańskiego ${ }^{18}$.

Wielką zasługą papieża Franciszka jest uświadomienie dzisiejszemu człowiekowi tego, jak ważna jest obecność drugiego człowieka. Stąd też przypomina zwłaszcza osobom duchownym i konsekrowanym o konieczności „duszpasterstwa obecności”. Wydaje się, że jest to jedna z największych i najważniejszych potrzeb współczesnego człowieka - jest nią bliskość, która staje się obecnością. Podczas wielu spotkań Papież zachęca i pokazuje, jak wielkim darem jest towarzyszenie drugiemu człowiekowi. W tym względzie przypomina pasterzom Kościoła o szczególnej ich roli w dziele ewangelizacji współczesnego świata. Pasterz to ten - podkreśla Franciszek - który winien być obecny z przodu owczarni jako jej pasterz i prowadzić ją we właściwym kierunku. Powinien być także pośród niej, wsłuchując się w jej głos, poznając jej problemy, radości i smutki. I wreszcie, powinien być obecny z tyłu, tam gdzie często są osoby słabnące w drodze, potrzebujące wsparcia, pomocy i dobrej rady. Ponadto pasterz winien pachnieć owczarnią; nie bać się jej zapachu. Równocześnie zadaniem pasterza jest też nieść zapach Boga do owczarni, która potrzebuje umocnienia na drodze wiary.

\footnotetext{
${ }^{16}$ Por. tamże, nr 128.

${ }^{17}$ Tamże, nr 169.

${ }^{18}$ Tamże.
} 
Mając na uwadze wskazania papieża Franciszka, należy stwierdzić, że bardziej niż kiedykolwiek potrzebujemy dziś mężczyzn i kobiet, którzy posiadają doświadczenie towarzyszenia, znających sposób postępowania. Potrzeba dziś ludzi potrafiących słuchać innych. A jest to szczególna zdolność serca, która stwarza poczucie bliskości i bezpieczeństwa. Słuchanie pomaga zrozumieć drugiego i pomóc mu odkryć drogi prowadzące do prawdziwego wzrostu. Dzięki temu zaczyna rozwijać się prawdziwe pragnienie realizacji ideałów życia chrześcijańskiego ${ }^{19}$.

W działaniu Kościoła wychodzącego - w stawaniu się uczniem-misjonarzem - nie sposób pominąć ludzi ubogich, którzy stanowią centrum misji samego Jezusa Chrystusa. On, będąc bogatym, stał się dla nas ubogim, aby nas swym ubóstwem ubogacić. Papież Franciszek w sposób szczególny zwraca uwagę na godność każdego ludzkiego życia. Wyraźnie też przypomina dzisiejszemu światu o ludziach ubogich, zepchniętych na margines życia społecznego, pozbawionych środków do życia. Są oni wielkim wyrzutem sumienia dla współczesnego świata zatopionego w kulturze hedonizmu, tymczasowości i wygody. Ojciec Święty wielokrotnie mówi, że pragnie Kościoła ubogiego dla ubogich ${ }^{20}$. I dodaje, że oni mogą nas wiele nauczyć. Oni to przez doświadczenie osobistego cierpienia znają Chrystusa cierpiącego. Stąd też, jak zachęca Papież, jest rzeczą konieczną, byśmy pozwolili, aby ubodzy nas ewangelizowali. Jesteśmy wezwani jako wspólnota wiary do odkrywania w tych ludziach oblicza samego Chrystusa. Naszym też zadaniem jest użyczanie im swego głosu w ich sprawach, stawania się dla nich przyjaciółmi, słuchania ich i przyjmowania od nich tajemniczej mądrości, którą Bóg pragnie nam przez nich przekazać ${ }^{21}$.

W ten sposób, wychodząc do dzisiejszego człowieka, spotykając się z nim w drodze, wsłuchując się w głos jego serca, stajemy się niczym Chrystus na drodze do Emaus. Dzięki temu każdy człowiek ma szansę spotkać się z głosem Dobrej Nowiny. Naszym zadaniem jest przede wszystkim nie ustawać w drodze. Mamy iść i głosić na wzór Chrystusa, który czuł się posłany do każdego człowieka ${ }^{22}$.

\footnotetext{
${ }^{19}$ Por. tamże, nr 171.

${ }^{20}$ Franciszek, Chciałbym Kościoła ubogiego dla ubogich. Przemówienie z 16 marca 2013 r., [w:] Franciszek, Chciałbym Kościoła ubogiego dla ubogich, Warszawa 2013, s. 94-96.

${ }^{21}$ Por. EG 198.

${ }^{22}$ Por. Franciszek, A. Tornielli, Miłosierdzie to imię Boga, przeł. J. Ganobis, Kraków 2016, s. 23-39.
} 


\section{ŚWIĘTOŚĆ BŁOGOSŁAWIEŃSTW W CODZIENNOŚCI}

Papież Franciszek, mówiąc o powołaniu do świętości, wskazuje na konkretną drogę jej realizacji. Tą drogą są Chrystusowe błogosławieństwa. Dla Ojca Świętego szczęśliwy lub błogosławiony staje się synonimem święty. Jest to bowiem człowiek wierny Bogu, żyjący Jego słowem i dający siebie w darze drugiemu człowiekowi. Być człowiekiem świętym - błogosławionym - to przede wszystkim iść pod prąd współczesnej mentalności, która próbuje zatopić człowieka w przestrzeni doczesności. Stąd też, Chrystusowe błogosławieństwa, które głosząc, nauczał: błogosławieni ubodzy w duchu, albowiem do nich należy królestwo niebieskie; błogosławieni cisi, albowiem oni na własność posiądq ziemię; błogosławieni, którzy się smuca, albowiem oni będq pocieszeni; błogosławieni, którzy łaknq i pragnq sprawiedliwości, albowiem oni będq nasyceni; błogosławieni miłosierni, albowiem oni miłosierdzia dostapiq; błogosławieni czystego serca, albowiem oni Boga oglądać będq; błogosławieni, którzy wprowadzaja pokój, albowiem oni będq nazwani synami Bożymi; błogosławieni, którzy cierpia prześladowanie dla sprawiedliwości, albowiem do nich należy królestwo niebieskie - winny stanowić regułę życia każdego wierzącego. Chrystus, wypowiadając poszczególne błogosławieństwa, zaprasza nas do konfrontacji naszego serca z Dobrą Nowiną. Jest to okazja, by zobaczyć to, w czym tak naprawdę upatrujemy bezpieczeństwa życia.

Ojciec Święty Franciszek zachęca do postawy wejścia w głąb naszego serca. Tam człowiek spotyka się z głosem Boga, który przypomina o naszym powołaniu i naszym przeznaczeniu. W ten sposób staje się on życiowym realistą, który widzi dobro, ale też dostrzega zło i nazywa je po imieniu. Odkrywa w ten sposób, że życie ma sens, gdy nie pozostaje się obojętnym na cierpienie drugiego człowieka. Osoba taka czuje się potrzebna i nie boi się zbliżyć, by dotknąć rany innych i współczuć ich słabości ${ }^{23}$.

Na drodze błogosławieństw niezwykle ważne jest życie w prawdzie, ponieważ to ona wyzwala człowieka z jego ograniczeń i zależności. Jest to, jak zaznacza Franciszek, droga miłości i miłosierdzia. Współcześnie szczególne miejsce w codziennym życiu zajmuje postawa przebaczenia. Ilość bowiem zadawanego bólu i cierpienia staje się dziś nie do opisania. Niemalże na każdym kroku spotykamy

${ }^{23}$ Franciszek, Gaudete et exsultate. Adhortacja apostolska o powołaniu do świętości w świecie współczesnym, Częstochowa 2018, 76 [dalej skrót: GE]. 
się z ludzkim nieszczęściem. Trwające konflikty międzynarodowe, kulturowe i etniczne sprawiają, że cierpią miliony niewinnych istot. Warto tu przytoczyć słowa Papieża, który mówi, że „prześladowania nie są rzeczywistością z czasów minionych, ponieważ również dzisiaj je znosimy, czy to w sposób okrutny, jak wielu współczesnych męczenników, czy to w sposób subtelniejszy, poprzez oszczerstwa i fałszerstwa. [...] Niekiedy chodzi o szyderstwa, które próbują oszpecić naszą wiarę i sprawić, byśmy uchodzili za osoby śmieszne"24.

Wobec skomplikowanej rzeczywistości, w której żyjemy, Ojciec Święty przypomina Chrystusowe słowa, że miara, jakiej używamy, aby zrozumieć i wybaczyć, zostanie zastosowana do nas samych, aby i nam przebaczyć. Stąd też, potrzeba miłosierdzia, tego od Boga i tego od człowieka. Miłosierdzie dostrzegane i okazywane staje się świętością. W ostateczności chodzi tak naprawdę o czyste serce. Ponieważ serce kochające nie dopuszcza do swego życia czegoś, co będzie zagrażało miłości, osłabiało ją lub narażało na niebezpieczeństwo jej utraty ${ }^{25}$.

Od życia w prawdzie Franciszek przechodzi do czynienia pokoju. Zaznacza, że nie jest czymś łatwym budować ewangeliczny pokój. Jest to niezwykle trudne zadanie, wymagające wielkiej otwartości umysłu i serca. Przy okazji Papież zaznacza, że nie da się budować pokoju zza biurka. Potrzeba osobistego zaangażowania. Wymaga to przede wszystkim wielkiej odwagi, dobrej woli, pogody ducha, kreatywności i wrażliwości. Zresztą sam Jezus podkreśla, że droga ta prowadzi niejednokrotnie pod prąd. Przypomina, że także prześladowanie jest wpisane w naszą codzienność wiary, bo kto chce zachować swoje życie, straci je ${ }^{26}$. Dlatego doświadczenie krzyża, jego trudu i udręki, staje się drogą naszego dojrzewania i uświęcania ${ }^{27}$. Codzienne przyjmowanie drogi Ewangelii, mimo że przynosi ona wiele trudności i problemów, staje się ostatecznie drogą chrześcijańskiej doskonałości ${ }^{28}$.

Realizacja błogosławieństw dokonuje się w codzienności. Tę codzienność wiary należy przeżywać z pasją, entuzjazmem i zaangażowaniem. Współczesne czasy charakteryzuje wspomniana postawa tymczasowości. Świętość natomiast potrzebuje wierności. Dlatego Ojciec Święty wskazuje przy okazji na istotne

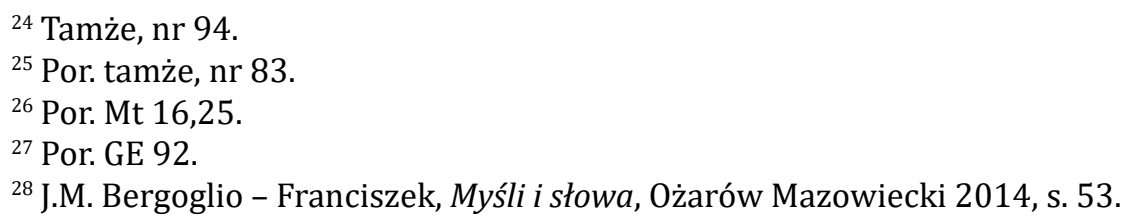


cechy, które są nieodzowne, by żyć Ewangelią błogosławieństw. Na pierwszym miejscu wymienia postawę wierności, cierpliwości i łagodności. Następnie wskazuje na radość i poczucie humoru oraz na zapał i śmiałość związaną z odwagą. To wszystko - jak podkreśla Franciszek - dokonuje się we wspólnocie i atmosferze modlitwy. Cechy te są niejako kluczem do realizacji ideału świętości zawartego w błogosławieństwach. Przyczyniają się one do pewnej wewnętrznej stabilności, a Ewangelia staje się stylem życia. Objawia się to w postawie wiernej miłości, która nie daje się ponieść niepokojom i trwa przy innych nawet wtedy, gdy nie przynosi osobistej satysfakcji ${ }^{29}$. Święty bowiem jest tym, który nie marnuje sił na to, by narzekać na błędy innych, i nie spogląda na nich z góry, lecz nie tracąc realizmu, oświeca innych pozytywnym i pełnym nadziei duchem.

Aktualizując osiem błogosławieństw w życiu codziennym, należy pamiętać, że Bóg zawsze jest nowością. Ta nowość sprawia, że jesteśmy nieustannie pobudzani do wyruszania w drogę na nowo, do zmiany miejsca, by wychodzić poza to, co znane, co wygodne i przyjemne. Jesteśmy prowadzeni często tam, gdzie nawet nie chcemy, tam gdzie jest najbardziej poraniona ludzkość, gdzie człowiek nieustannie poszukuje odpowiedzi na pytanie o sens swojego życia. Dlatego, jak zaznacza Franciszek, „Bóg się nie boi! On się nie lęka! Zawsze wychodzi poza nasze schematy i nie boi się obrzeży. Sam stał się peryferiami. Dlatego jeśli odważymy się wyruszyć na obrzeża, to tam Go znajdziemy: On już tam będzie. Jezus uprzedza nas w sercu naszego brata, w jego zranionym ciele, w jego uciszonym życiu, w jego mrocznej duszy. On już tam jest" ${ }^{\prime 30}$.

Droga do świętości zakłada współuczestnictwo. Stąd też jej realizacja dokonuje się we wspólnocie. Uświęcenie jest drogą wspólnotową, którą pokonujemy wraz z innymi. Życie, praca, codzienne obowiązki są drogą wzajemnego rozwoju. Warto tu nadmienić, że Chrystus, wypowiadając błogosławieństwa, mówi: „błogosławieni”, a nie „błogosławiony”. Wszystko to wskazuje, że droga do świętości bez obecności drugiego człowieka jest wręcz niemożliwa. Stąd też doświadczenie wspólnoty w różnych jej wymiarach, szczególnie zaś w wymiarze duchowym,

\footnotetext{
${ }^{29}$ Por. GE 112.

${ }^{30}$ Tamże, nr 135.
} 
sprawia, że będąc jej uczestnikami, stajemy się także darem dla innych, zwłaszcza wtedy, gdy przyczyniamy się do budowania jedności ${ }^{31}$.

\section{ŚWIĘCI POŚRÓD NAS}

Franciszek zaznacza, że mobilizacją dla nas jest przykład wielu kapłanów, sióstr zakonnych oraz osób świeckich, którzy z wielką wiernością poświęcają swoje życie przepowiadaniu i służbie. W wielu sytuacjach ich życie narażone jest na niebezpieczeństwo nawet jego utraty. Ich świadectwo przypomina, że Kościół potrzebuje prawdziwych świadków wiary, misjonarzy, którzy pochłonięci pasją głoszenia Dobrej Nowiny zaskakują, prowokują i wyrywają nas z tzw. urzq̨dzonej egzystencji i zachęcają do porzucenia spokojnej oraz znieczulającej przeciętności ${ }^{32}$. Z drugiej strony należy pamiętać, że nasze zaangażowanie nie powinno opierać się wyłącznie na programach promocji i opieki społecznej. W tym wszystkim winniśmy skierować uwagę na konkretnego człowieka. Ojciec Święty nazywa to uwagą pełną miłości. Ona to staje się początkiem prawdziwego zatroskania o drugą osobę. Stąd też prawdziwa miłość zawsze zawiera w sobie element kontemplacji, zatrzymania się. $\mathrm{Z}$ takiego miłosnego zatrzymania się przy drugim człowieku rodzi się bezinteresownośćs ${ }^{33}$.

Świętość to obecność. Obecność obok, obecność $z$ i obecność przy konkretnej osobie. Papież Franciszek przypomina często, że jednym z największych aktów miłosierdzia, jakie człowiek może okazać drugiemu w dzisiejszym świecie, jest poświęcić mu swój czas. W tym względzie pierwszą motywacją winna stać się dla nas miłość Jezusa, który nam ją okazuje. Jest to miłość zbawiająca. Przykładem dla nas są święci każdych czasów. Oni to w sposób bezkompromisowy potrafili dostrzec oblicze Chrystusa w drugim człowieku. To zadanie jest niezwykle aktualne i dziś. Dlatego Ojciec Święty zachęca, abyśmy poszerzyli swój horyzont patrzenia i dostrzegali świętych, którzy żyją obok nas. I dodaje: „lubię dostrzegać świętość w cierpliwym ludzie Bożym: w rodzicach, którzy z wielką miłością pomagają dorastać swoim dzieciom, w mężczyznach i kobietach pracujących, by zarobić na chleb, w osobach chorych, w starszych zakonnicach, które nadal się

${ }^{31}$ Zob. F. Ambrogetti, S. Rubin, Jezuita. Papież Franciszek, przeł. A. Fijałkowska-Żydok, Kraków 2013, s. 153-167.

${ }^{32}$ Por. GE 138.

${ }^{33}$ Por. EG 199. 
uśmiechają. [...] Jest to często świętość z sąsiedztwa, świętość osób, które żyją blisko nas i są odblaskiem obecności Boga, albo by użyć innego wyrażenia, są klasą średnią świętości" ${ }^{\prime 3}$.

\section{Bardziej niż kiedykolwiek potrzebujemy dziś mężczyzn i kobiet, którzy posiadają doświadczenie towarzyszenia. Przykładem dla nas są święci każdych czasów. Oni to w sposób bezkompromisowy potrafili dostrzec oblicze Chrystusa w drugim człowieku.}

Ojciec Święty Franciszek, mówiąc o świętości pośród nas, niejako prowokuje, byśmy zadali sobie pytanie: co z naszq osobistq świętościq̨? Możemy bowiem dostrzegać innych, podziwiać ich oddanie, a sami nie chcemy oderwać się od własnych schematów myślowych ${ }^{35}$. Dlatego z przekonaniem stwierdza, że świętość to zadanie także dla ciebie. Często bowiem istnieje pokusa, by sądzić, że świętość jest zarezerwowana dla tych, którzy mają możliwość oddalenia się od zwykłych zajęć, by poświęcić wiele czasu modlitwie i służbie. Stąd też, słyszymy wołanie papieskie - wszyscy jesteśmy powołani, by być świętymi. Papież mówi: „jesteś osobą konsekrowaną? Bądź świętym, żyjąc radośnie swoim darem. Jesteś żonaty albo jesteś mężatką? Bądź świętym, kochając i troszcząc się o męża lub żonę, jak Chrystus o Kościół. Jesteś pracownikiem? Bądź świętym, wypełniając uczciwie i kompetentnie twoją pracę w służbie braciom. Jesteś rodzicem, babcią lub dziadkiem? Bądź świętym, cierpliwie ucząc dzieci naśladować Jezusa. Sprawujesz władzę? Bądź świętym, walcząc o dobro wspólne i wyrzekając się swoich interesów osobistych"36.

Świętymi się nie rodzimy, ale nimi stajemy. Świętość to nasze życiowe powołanie, które wypełnia się wtedy, gdy każdego dnia odpowiadamy na wołanie

${ }^{34}$ GE 7.

${ }^{35}$ Por. Franciszek, Christus vivit. Posynodalna adhortacja apostolska do młodych i całego Ludu Bożego, Wrocław 2019, nr 273 [dalej skrót: CV].

${ }^{36} \mathrm{GE} 14$. 
Chrystusa ${ }^{37}$. Warto podjąć wysiłek zmiany swego życia. Jest to wyraz naszej odwagi, a przede wszystkim posłuszeństwa natchnieniom Ducha Świętego, który nam je daje, byśmy czynili dobro i w ten sposób, zmieniając siebie, zmieniali świat. Potrzeba wierności wobec miłości, do której wzywa nas Bóg. Takie działanie tworzy przestrzeń duchowego wzrostu osobistego i tych, z którymi się spotykamy ${ }^{38}$. Tak więc, ofiarowując siebie, nigdy siebie nie tracimy, lecz odnajdujemy na nowo. W ten sposób, jak zaznacza Franciszek, Kościół staje się szpitalem polowym, a my jesteśmy w nim lekarzami i pacjentami. Tymi, którzy leczą, i tymi, którzy potrzebują uzdrowienia.

\section{CZUWAĆ, BY NIE UTRACIĆ WRAŻLIWOŚCI}

Ojciec Święty Franciszek zaznacza, że życie chrześcijańskie jest nieustaną walką; jest nieustannym zmaganiem się ze sobą, swoimi słabościami i ograniczeniami. Stąd też potrzeba siły i odwagi, by oprzeć się wszelkim pokusom i głosić Ewangelię. I choć wysiłek, jaki podejmujemy, jest niekiedy nieadekwatny do uzyskiwanych rezultatów, to jednak trzeba zaznaczyć, że walka ta jest piękna, ponieważ za każdym razem pozwala nam świętować, gdy Chrystus zwycięża w naszym sercu $^{39}$. By tak było, nieodzowna jest postawa czuwania, która chroni nas przed utratą wrażliwości na działanie Ducha Świętego. Niestety, współcześnie jesteśmy świadkami pojawiającej się duchowej acedii. Wchodzi ona w życie współczesnego Kościoła, powodując pewne uśpienie. Wiąże się to z faktem, że osoby uważające się za wierzące odczuwają potrzebę zachowania swojej przestrzeni autonomii. Powoduje ona pewną niezależność, a w konsekwencji prowadzi do moralnego subiektywizmu ${ }^{40}$.

Okazuje się, że źródłem wspomnianej acedii niekoniecznie jest nadmiar aktywności, który wprowadza pewien nieład w życie duchowe, lecz brak właściwej motywacji działania. Sprawia ona - jak zaznacza Papież - że obowiązki zaczynają męczyć, a nawet mogą prowadzić do postępującej choroby. Ta duszpasterska

${ }^{37}$ Por. J. Kiciński, Powołanie - konsekracja - misja: personalistyczny aspekt teologii życia konsekrowanego we współczesnym Magisterium Kościoła, Wrocław 2009, s. 54-56.

${ }^{38}$ Zob. L.A. Tagle, L. Fazzini, G. Fazzini, Radość Ewangelii. Rozmowy o odnowie Kościoła, przeł. A j. włoskiego K. Stopa, z j. angielskiego A. Czyżewska-Felczak, Kraków 2019, s. 121-126.

${ }^{39}$ Por. GE 158.

${ }^{40}$ Por. EG 81. 
acedia może mieć różne oblicza ${ }^{41}$. Niektórzy popadają w nią, ponieważ podtrzymują na siłę projekty nie do zrealizowania i nie realizują chętnie tego, co mogliby spokojnie robić. Inni dlatego, że nie akceptują dokonującej się ewolucji procesów i chcą, aby wszystko spadło z nieba. Jeszcze inni, ponieważ przywiązują się do niektórych projektów lub tzw. snów o sukcesie, podtrzymywanych własną próżnością. Niektórzy zaś dlatego, że stracili realny kontakt z ludźmi w odpersonalizowanym duszpasterstwie. Zwracają oni większą uwagę na organizację, niż na osoby, tak że bardziej zajmują się planem drogi niż samą drogą. Jeszcze inni popadają w acedię, ponieważ nie nauczyli się czekać, brak im cierpliwości i chcą panować nad rytmem życia. To dzisiejsze gorączkowe pragnienie osiągnięcia natychmiastowych wyników sprawia, że zaangażowani w duszpasterstwie często nie znoszą pojawiających się sprzeczności i nie akceptują porażki, krytyki i krzyża ${ }^{42}$.

Omawiając zagrożenia na drodze do świętości, Ojciec Święty wskazuje także na tzw. szary pragmatyzm, w którym na pozór wszystko postępuje zgodnie z zamierzeniami, a tak naprawdę rzeczywistość wiary wyczerpuje się i stacza w duchową miernotę. Postawa ta prowadzi do psychologii grobu, która wprowadza duszpasterskie obumieranie i skostnienie. Osłabiony zostaje zapał apostolski i zaczyna pojawiać się pesymizm duszpasterski. Jedną z najpoważniejszych pokus tłumiących zapał i odwagę - podkreśla Franciszek - jest poczucie przegranej, co sprawia niezadowolenie i rozczarowanie ${ }^{43}$. Wiadomo też, iż w wielu miejscach doszło i dochodzi do duchowego pustynnienia. Jest to owoc duszpasterskiej bezradności, a także współczesnej mentalności, która próbuje budować społeczeństwo bez Boga, albo niszczy swoje chrześcijańskie korzenie.

Przedstawiona sytuacja jest wyzwaniem dla dzisiejszego Kościoła, zachętą do postawy czuwania. Dlatego Ojciec Święty przypomina, że nikt nie może podjąć walki, jeśli nie wierzy w zwycięstwo. Trzeba, nawet z bolesną świadomością swojej słabości i kruchości, kroczyć naprzód i nie poddawać się w chwilach zwątpienia. Należy przypominać sobie w sercu słowa powiedziane przez Chrystusa: „Wystarczy ci Mojej łaski. Moc bowiem w słabości się doskonali”"44. Dlatego chrześcijańskie zwycięstwo zawsze przychodzi przez krzyż, który w ostateczności

${ }^{41}$ Zob. N. Diat, kard. R. Sarah, Wieczór się zbliża i dzień już się chyli, przeł. A. Kuryś, Warszawa 2019, s. 161-171.

${ }^{42}$ Por. EG 82.

${ }^{43}$ Zob. tamże, nr 82-85.

${ }^{44} 2$ Kor $12,9$. 
staje się sztandarem zwycięstwa ${ }^{45}$. Droga do świętości owocuje w czasie pokojem i radością, które są darami Ducha Świętego. Wymaga to jednak tego, abyśmy szli z zapalonymi pochodniami i zachowywali czujność. Niezwykle ważne jest tu właściwe rozeznanie duchowe ${ }^{46}$. Papież Franciszek mówi nawet o pilnej potrzebie rozeznawania ${ }^{47}$. Istotne jest to wówczas, gdy w naszym życiu pojawia się jakaś nowość. Trzeba wtedy rozeznać, czy jest ona „nowym winem”, które pochodzi od Boga, czy też zwodniczą nowością tego świata lub ducha nieczystego. Rozeznanie jest konieczne nie tylko w chwilach nadzwyczajnych, ale nade wszystko wtedy, gdy trzeba podejmować konkretne decyzje ${ }^{48}$.

Okazuje się, że nawet wówczas, gdy rozeznajemy, przeżywamy także porażki, które nie zawsze zależne są tylko od nas. Mimo naszych dobrych wysiłków, doświadczamy ludzkiej bezradności. Ta pozorna niemoc, a dla niektórych widmo chylącego się Kościoła nie jest zapowiedzią Jego upadku, ale wyzwaniem do większego zaufania, większej odwagi, większej wiary. Niekiedy doświadczenie bezradności sprawia, że człowiek całkowicie jest w stanie powierzyć się Bogu i Jego opiece. Wychodząc zaś od doświadczenia jawiącej się pustki duchowej dzisiejszego człowieka, możemy na nowo odkrywać radość wiary oraz jej życiowe znaczenie. Na tej pustyni potrzeba szczególnie tych, którzy własnym życiem wskazują drogę ku Ziemi Obiecanej ${ }^{49}$.

\section{ZAWIERZENIE MARYI}

Ojciec Święty Franciszek niemalże na każdym miejscu podkreśla obecność Maryi. Jest Ona dla niego Matką, Formatorką, Wychowawczynią i wspaniałym przykładem świętości. Na wzór swoich poprzedników - św. Jana Pawła II i Benedykta XVI - zawierza on właśnie Jej najważniejsze wydarzenia swego życia. Maryja jest dla Papieża wzorem odpowiedzi na słowo Boże i czynienia z niego treści swego

${ }^{45}$ Franciszek, Odrzucając Krzyż, nie jesteśmy Uczniami Chrystusa. Homilia z 14 marca 2013, [w:] Papież Franciszek, Chciałbym Kościoła ubogiego dla ubogich, dz. cyt., s. 88-89.

${ }^{46}$ Kongregacja do spraw Instytutów Życia Konsekrowanego i Stowarzyszeń Życia Apostolskiego, Rozpoznawajcie, Warszawa 2014, nr 11-12.

${ }^{47}$ Por. Franciszek, Laudato si'. Encyklika poświęcona trosce o wspólny dom, Wrocław 2015, nr 62-69.

${ }^{48}$ Por. GE $169-171$.

${ }^{49}$ Por. EG 86. 
życia. Ona gromadzi Kościół na modlitwie i na rozeznaniu; Ona towarzyszy wszelkim dziełom apostolskim. Maryja dla Franciszka jest obecna. Papież nazywa Maryję Matką ewangelizującego Kościoła i przypomina, że bez Niej nie potrafilibyśmy zrozumieć, czym naprawdę jest ewangelizacja. Wewnętrzna więź między Maryją a Kościołem stwarza niepowtarzalną przestrzeń miłości, która jest obecna w każdym miejscu i w każdym czasie. Maryja jest zawsze uważną Przyjaciółką, która czuwa, troszczy się o to, by nigdy nie zabrakło miłości w naszym życiu. Jako Matka zaś jest znakiem nadziei dla wszystkich, którzy są na granicy jej utraty. W końcu - jak podkreśla Franciszek - Maryja jest Misjonarką zbliżającą się do nas, by uczestniczyć w naszym życiu i otwierać nasze serca na łaskę wiary ${ }^{50}$.

Dla papieża Franciszka zawierzenie Maryi jest prawdziwym synowskim oddaniem. Jest Ona dla niego Świętą pośród świętych i najbardziej błogosławioną. Maryja wskazuje, towarzyszy i uczestniczy w naszej pielgrzymce życia. Nawet wówczas, gdy okazujemy się słabi, upadamy, to Ona jako Matka bierze nas na swoje ramiona. Rozmowa zaś z Maryją zawsze jest pocieszeniem i uświęceniem. Ona nigdy nie potrzebuje wielu słów, bo to jest Matka, która wszystko rozumie ${ }^{51}$.

\section{PODSUMOWANIE}

Powyższa analiza miała na celu ukazanie papieża Franciszka jako pasterza zatroskanego o świętość Kościoła. Jego pontyfikat naznaczony jest wielkim zaufaniem do Chrystusa i Jego Matki - Maryi. Ojciec Święty w sposób bardzo jasny pokazuje Kościołowi, że jego jedyną drogą jest świętość. Świętość ta realizowana jest we wspólnocie. Dla Franciszka nie ma sytuacji straconych, każde spotkanie z człowiekiem jest okazją do głoszenia Dobrej Nowiny, do wzbudzenia w drugim człowieku nadziei - nadziei na lepsze jutro. Swoim życiem pokazuje, że tak naprawdę nic się nie dzieje bez naszego zaangażowania. Gdy człowiek podejmie czynną współpracę z objawiającą się łaską Boga, może dokonać rzeczy po ludzku niemożliwych może stać się świętym ${ }^{52}$.

${ }^{50}$ Por. tamże, nr 286.

${ }^{51}$ Por. GE 176.

${ }^{52}$ Benedykt XVI, Verbum Domini. Adhortacja apostolska o Słowie Bożym w życiu i misji Kościoła, Kraków 2010, nr 88. 


\section{Nie bój się świętości. Nie odbierze ci ona sił, życia ani radości.}

Kończąc, warto przypomnieć słowa Ojca Świętego Franciszka, który mówi do każdego człowieka: „Nie bój się świętości. Nie odbierze ci ona sił, życia ani radości. Wręcz przeciwnie, ponieważ staniesz się tym, co zamyślał Ojciec, kiedy ciebie stworzył, i będziesz wierny twojej istocie. Zależność od Niego uwalnia nas od zniewoleń i prowadzi nas do uznania naszej godności”53. I dodaje: „Każdy chrześcijanin, na tyle, na ile się uświęca, staje się bardziej owocny dla świata" ${ }^{54}$. Papież dodaje wszystkim odwagi, mówiąc: „Nie lękaj się dążyć wyżej, dać się miłować i wyzwolić przez Boga. Nie bój się pozwolić, aby cię prowadził Duch Święty. Świętość nie czyni cię mniej ludzkim, ponieważ jest spotkaniem Twojej słabości z siłą łaski" ${ }^{\prime 5}$.

\section{BIBLIOGRAFIA}

Ambrogetti F., Rubin S., Jezuita. Papież Franciszek, przeł. A. Fijałkowska-Żydok, Kraków 2013.

Benedykt XVI, Verbum Domini. Adhortacja apostolska o Słowie Bożym w życiu i misji Kościoła, Kraków 2010.

Bergoglio J.M.-Franciszek, Myśli i słowa, Ożarów Mazowiecki 2014.

Diat N., Sarah R. kard., Wieczór się zbliża i dzień już się chyli, przeł. A. Kuryś, Warszawa 2019.

Franciszek, Chciałbym Kościoła ubogiego dla ubogich. Przemówienie z 16 marca 2013 r., [w:] Papież Franciszek, Chciałbym Kościoła Ubogiego dla ubogich, Warszawa 2013.

Franciszek, Christus vivit. Adhortacja apostolska do młodych i całego Ludu Bożego, Wrocław 2019.

Franciszek, Czuwanie modlitewne podczas Światowych Dni Młodych w Krakowie (30.07.2016), [w:] Papież Franciszek w Polsce 27-31 lipca 2016, Marki 2016.

Franciszek, Evangelii gaudium. Adhortacja apostolska o głoszeniu Ewangelii we współczesnym świecie, Kraków 2014.

Franciszek, Gaudete et exsultate. Adhortacja apostolska o powołaniu do świętości w świecie współczesnym, Częstochowa 2018.

\footnotetext{
${ }^{53} \mathrm{GE} 32$.

${ }^{54}$ Tamże, nr 33.

${ }^{55}$ Tamże, nr 34.
} 
Franciszek, Laudato si'. Encyklika poświęcona trosce o wspólny dom, Wrocław 2015.

Franciszek, Odrzucając Krzyż, nie jesteśmy Uczniami Chrystusa. Homilia z 14 marca 2013 r., [w:] Papież Franciszek, Chciałbym Kościoła Ubogiego dla ubogich, Warszawa 2013.

Franciszek, Radujcie się. List okólny do osób konsekrowanych na rozpoczęcie Roku Życia Konsekrowanego, Warszawa 2017.

Franciszek, Wolton D., Otwieranie drzwi. Rozmowy o Kościele i świecie, przeł. M. Chojnacki, Kraków 2018.

Jan Paweł II, Redemptoris missio. Encyklika o stałej aktualności posłania misyjnego, Kraków 1996.

Kiciński J., Powołanie - konsekracja - misja: personalistyczny aspekt teologii życia konsekrowanego we wspótczesnym Magisterium Kościoła, Wrocław 2009.

Kongregacja do spraw Instytutów Życia Konsekrowanego i Stowarzyszeń Życia Apostolskiego, Głoście. Do osób konsekrowanych, świadków Ewangelii wśród narodów, Warszawa 2014.

Kongregacja do spraw Instytutów Życia Konsekrowanego i Stowarzyszeń Życia Apostolskiego, Rozpoznawajcie, Warszawa 2014.

Tagle L.A. kard., Fazzini L., Fazzini G., Radość Ewangelii. Rozmowy o odnowie Kościoła, przeł. Z j. włoskiego K. Stopa, z j. angielskiego A. Czyżewska-Felczak, Kraków 2019.

Tornielli A., Miłosierdzie to imię Boga, przeł. J. Ganobis, Kraków 2016.

\section{Biogram}

Bp Jacek Kiciński CMF - profesor zw. Papieskiego Wydziału Teologicznego we Wrocławiu, kierownik Katery Duchowości Kapłańskiej i Życia Konsekrowanego, przewodniczący Komisji Życia Konsekrowanego i Stowarzyszeń Życia Apostolskiego KEP, autor książek i wielu artykułów poświęconych teologii duchowości, zwłaszcza duchowości kapłańskiej i osób konsekrowanych.

e-mail: jkicinskicmf@gmail.com

ORCID: 0000-0002-9032-9584 


\title{
Apostolische Auslandsreisen von Papst Franziskus, darunter Missionsreisen, in den wichtigsten nationalen Internetportalen (Jahr 2018)
}

\author{
Apostolic journeys of Pope Francis, including missionary \\ ones, in the most important national websites (2018)
}

\section{ZUSAMMENFASSUNG}

Die Kirche bediente sich in ihrer Tätigkeit und bedient sich weiterhin nicht nur der christlichen, sondern auch der säkularen

Medien. In der Geschichte waren es mit der technologischen Entwicklung:

Zeitschriften, Radio, Fernsehen und schließlich Internetmedien. Dieses letzte Medium verdrängt recht effektiv die früher genutzten Medien und wird ein Ort für

Kommunizieren von Gedanken. In den vorgenommenen Forschungen wurden die wichtigsten meinungsbildenden Portale in

Polen (www.onet.pl, www.wp.pl, www.interia. pl, www.gazeta.pl, www.o2.pl i www.fakt.pl) auf Veröffentlichung von Texten betreffend vier apostolische Auslandsreisen, darunter

Missionsreisen, von Papst Franziskus im Jahre 2018 analysiert. Es wurden die Anzahl, die Qualität, die Art und die Zeit der Veröffentlichungen untersucht sowie pastorale Schlussfolgerungen bezüglich der

Anwesenheit der Mission, der päpstlichen Pilgerfahrten sowie der ekklesischen Tätigkeit

in führenden Internet- und Laienportalen gezogen. Auf dieser Grundlage wurden folgende Forschungshypothesen beantwortet. Es scheint, die erste: „Die Medien in Polen informieren sachgemäß über die Auslandspilgerreisen von Papst
Franziskus (quantitativ und qualitativ)“ sei unbestätigt. Die zweite: „Die Vorbereitung der Geistlichen zur Benutzung neuer Medien und zur Benachrichtigung über die mit der Kirche verbundenen Fragen ist sachgemäß" ist unbestätigt; und die dritte: „Die Anzahl der Informationen und die Benachrichtigungsart über die Auslandspilgerreisen ist ungenügend" sei bestätigt.

\section{SCHLÜSSELWÖRTER:}

apostolische Reisen, Papst Franziskus, neue Medien, Internet, meinungsbildende Portale, Missionen, Kirche, Jahr 2018

\section{SUMMARY}

In its activity, the Church used and uses the media, not only defined as Christian but also as secular ones. In history, along with technological development, these were: magazines, radio, television, and finally internet media. This last medium quite effectively displaces previously used and becomes a place of communication of thoughts. The undertaken research analyzed the most important opinion forming portals in Poland (www.onet.pl, www.wp.pl, www. interia.pl, www.gazeta.pl, www.o2.pl and www.fakt.pl) in terms of publishing texts regarding four foreign apostolic journeys 
of Pope Francis, including missionary visits in 2018. The number, quality, type and time of publication were examined, and pastoral conclusions regarding the presence of missions, papal pilgrimages and ecclesial activities on secular leading websites were considered. On this basis, the following research hypotheses were

answered, it seems that the first one:

"The media in Poland properly inform about foreign pilgrimages of Pope Francis

(quantitatively and qualitatively)" - is unconfirmed. Second: "Preparation of clergy to use new media and to inform about issues related to the Church is appropriate" - is unconfirmed; and the third: "The amount of information and information on foreign pilgrimages is insufficient" - confirmed.

\section{KEYWORDS:}

apostolic journeys, pope Francis, new media, Internet, opinion leaders, mission, Catholic Church, year 2018

\title{
Zagraniczne podróże apostolskie papieża Franciszka, w tym misyjne, w najważniejszych krajowych portalach internetowych (rok 2018)
}

\begin{abstract}
ABSTRAKT
Kościół w swojej działalności posługiwał się i posługuje mediami, nie tylko tymi z definicji chrześcijańskimi, ale także świeckimi. W historii wraz z rozwojem technologicznym były to: czasopisma, radio, telewizja, aż w końcu media internetowe. To ostatnie medium dość skutecznie wypiera wcześniej używane i staje się miejscem komunikowania myśli. W podjętych badaniach poddano analizie najważniejsze portale opiniotwórcze w Polsce (www.onet.pl, www. wp.pl, www.interia.pl, www.gazeta.pl, www.o2.pl i www.fakt.pl) pod względem publikowania tekstów dotyczących czterech zagranicznych podróży apostolskich papieża Franciszka, w tym tych misyjnych, w roku 2018. Zbadano liczbę, jakość, rodzaj i czas publikacji, a także wysunięto wnioski pastoralne dotyczące obecności misji, pielgrzymek papieskich oraz działalności eklezjalnej w laickich wiodących portalach internetowych. Na tej podstawie odpowiedziano na następujące hipotezy badawcze; wydaje się, że pierwsza: „Media w Polsce właściwie informują o pielgrzymkach zagranicznych papieża Franciszka (ilościowo i jakościowo)" jest niepotwierdzona. Druga: „Przygotowanie duchownych do posługiwania się nowymi mediami i informowania o zagadnieniach związanych z Kościołem jest odpowiednie" - jest niepotwierdzona; a trzecia: „Liczba informacji i sposób informowania o zagranicznych pielgrzymkach są niewystarczające" - potwierdzona.
\end{abstract}

\section{SŁOWA KLUCZOWE:}

podróże apostolskie, papież Franciszek, nowe media, Internet, portale opiniotwórcze, misje, Kościół, 2018 r.

$S$ eit Anfang der Existenz der sozialen Kommunikationsmittel weckte das Papstamt das Interesse in Polen. Die Menschen interessierten sich, vielleicht weniger, für Neuheiten aus der Lehre der Päpste und mehr für Details aus dem Alltag des Apostolischen Stuhls, darunter für apostolische Reisen. Zweifelsohne fiel die 
Gipfelzeit dieses Interesses im Inland zwangsläufig für den Pontifikat von Johannes Paul II an. Aktueller Bischof von Rom: Jorge Mario Bergoglio SJ (geb. am 17. Dezember 1936 in Buenos Aires) - argentinischer römisch-katholischer Geistliche wurde am 13. März 2013 zum 266. Papst. Wie es schein, weckte auch der Pontifikat von Papst Franziskus Interesse der weltweiten und der polnischen sozialen Kommunikationsmittel. Insbesondere gilt es für die Frage der Flüchtlinge oder der Lehre betreffend die Ehe und die Lebensübertragung, den Ökumenismus oder den religionsübergreifenden Dialog und in der letzten Zeit betreffend das Priestertum und die Eucharistie. Die Art und Weise selbst der anschaulichen und kerygmatischen Übermittlung des Inhalts scheint nicht immer verständig zu sein, wird es jedoch sicherlich von den sowohl säkularen als auch ekklesischen Medien umfangreich übertragen und kommentiert. Es scheint, dass dieses Interesse am Anfang seines Pontifikats war, und es wächst dann, wenn der Papst von das Interesse der Medien weckende Themen spricht oder wenn er mehr Interesse weckende Bilder in seiner Übermittlung verwendet. Das Internet und insbesondere es nutzende Medien, die von Theoretikern der sozialen Kommunikationsmittel neue Medien genannt werden ${ }^{1}$, verdrängt langsam die Papierversionen der

\footnotetext{
${ }^{1}$ Neue Medien sind „Techniken, Technologien sowie Institutionen, die zur Kommunikation dienen, und die digitale Verfahren zur Erfassung, Aufzeichnung und Speicherung von Daten, zur Erstellung und Übertragung von Übermittlungen nutzen. Neue Medien zeichnen sich durch Hypertextstruktur der Übermittlung und des Empfangs, Programmierungsmöglichkeit (Asynchronie des Sendens und des Empfangs), Interaktivität, Kumulativität, globale Reichweite und gleichzeitig Individualisierung des Zugangs aus" - E. Chudziński [Red.], Słownik wiedzy o mediach, Warszawa - Bielsko-Biała 2007, S. 45. Unter den Medientheoretikern ist bezüglich der Definition die Diskussion im Gange, ob die Internetseiten und -portale auch, oder nur die sozialen Medien zu „neuen Medien“ gehören. Viele von ihnen, wie z. B. Lev Manowich, qualifiziert unter neuen Medien auch die Internetseiten und -portale. Andere - wie z. B. Paul Levinson - schlagen ihre Abtrennung als separate Mediengruppe vor. Mit der Zeit evolvierte die Einstellung von Manovich und Levinson, Magdalena Szpunar in Polen und heute spricht man eher von der Kommunikation anhand der Internetseiten, darunter der Portale sowie der sozialen Medien, und kommt man vom Termin „neue Medien“ ab. Daher ist der Begriff „neue Medien“ kein scharfer und transparenter Begriff mehr und für die Zwecke der Arbeit nennen wir sie: „Kommunikation anhand der Internetseiten sowie der sozialen Medien“ oder „Kommunikation anhand des Internets“, „Internetmedien“ und ähnlich. L. Manovich, Język nowych mediów, Warszawa 2006; derselbe, New Media From Borges to HTML, Massachusetts 2003 oder P. Levinson, Nowe nowe media, Kraków 2010. Über weitergehende Versuche ihres Definierens, die laufende Diskussion schreiben auch: M. Szpunar, Czym sq nowe mediapróba konceptualizacji, in: „Studia medioznawcze” 2008, (35) 4, S. 32; dieselbe, W stronę nowych mediów, Toruń 2010; dieselbe, Imperializm kulturowy Internetu, Kraków 2017, S. 3-134;
} 
Zeitschriften, das Radio und das Fernsehen, daher wurde es ein Ort, wo viele Veröffentlichungen über den Papst platziert werden. In diesem Gebiet erfolgt derzeit, wie es scheint, der größte Fluss von Informationen, Ideen und Gedanken. Die beliebtesten allgemeinen, publizistischen Dienste in Polen sind: www.onet.pl, www. wp.pl, www.interia.pl, www.gazeta.pl, www.se.pl und www.o2.pl. Es ist erwähnenswert, dass das Portal www.wp.pl die größte Lesergruppe hat, das ein Niveau von 17,2 Mio. Nutzer monatlich erreicht, was rund 62\% der Internetnutzer in Polen entspricht, und das Portal www.fakt.pl die kleinste (entsprechend 4,4 Mio., d. h. 20\% der Nutzer) ${ }^{2}$. Diese Portale haben somit eine riesige meinungsbildende Rolle, die die Haltung seiner Nutzer bildet, umso mehr, dass der Anteil der christlichen und katholischen Portale am Markt der Internetmedien gering ist ${ }^{3}$.

Die Kirche bemerkt die Notwendigkeit seiner Präsenz auf diesem Gebiet und ihre Lehre ist insbesondere in den Botschaften für den Tag der sozialen Kommunikationsmittel, seit 1990, mit dem Erscheinen neuer Kommunikationskanäle verbunden. Neue Informationstechnologien bilden für die Kirche Werkzeuge, die zur Erfüllung ihrer Evangelisierungsmission dienen. Theologen der sozialen Kommunikationsmittel weisen darauf hin, dass obwohl bis vor Kurzem „die Kirche Missionen führte und das Korn des Evangeliums vom Kontinent zum Kontinent übertrug, betritt sie um die Wende des 20. und 21. Jahrhunderts nach Geburt

K. Krzysztofek, Status mediów cyfrowych: stare i nowe paradygmaty, in: „Global Media Journal - Polish Edition" 2006, (1) 1, S. 14; M. Nieć, Komunikowanie społeczne i media, Warszawa 2010, S. 60-72; K. Roman, Najnowsze nowe media i stare nowe media. Spór o definicję nowych mediów, in: „Dyskurs” 2016, (22) 2, S. 20-39; T. Goban-Klas, Media i komunikowanie masowe. Teorie i analizy prasy, radia, telewizji i Internetu, Warszawa 1999; I. Hofman, Paradygmaty nowej dyscypliny, in: „Studia Medioznawcze” 2019, (79) 4, S. 308-317.

${ }^{2}$ Siehe: Laut der Forschungen gehören zu den meinungsbildenden Portalen, die das Lesen auf dem Niveau von ca. 6 Mio. Nutzer in Polen erreichen: www.wp.pl (17,2 Mio. Nutzer, 62\% Bereich im Internet), www.onet.pl (17,0 Mio., 61,0\%), www.interia.pl (13,4 Mio., 48,3\%), www.gazeta.pl (11,0 Mio., 40,0\%), www.se.pl (8,30 Mio., 30,0\%), www.o2.pl (8,30 Mio., 30,0\%) und www.fakt.pl (4,4 Mio., 20,2\%). Quelle: Megapanel PBI/Gemius, Dezember 2019, Anzahl der Versuchspersonen: N=204 618, mit der Forschung umfasste Gruppe: 7-75 Jahre.

${ }^{3}$ Siehe: Laut dieser Forschungen waren die am häufigsten besuchten christlichen Webseiten: www.deon.pl (0,71 Mio. Nutzer, 2,53\%), www.gosc.pl (0,71 Mio., 2,50\%), www.opoka.org.pl (0,57 Mio., 2,05\%), www.aleteia.org (0,55 Mio., 1,95\%), www.wiara.pl (0,47 Mio., 1,67\%), www.misyjne.pl (0,46 Mio., 1,62\%), www.niedziela.pl (0,45 Mio., 1,60\%). Quelle: Megapanel PBI/Gemius, November 2019, Anzahl der Versuchspersonen: N=145 266, mit der Forschung umfasste Gruppe: 7-75 Jahre. 
Christi einen ganz „neuen Boden ${ }^{4 “}$. Der erste Papst, der die besondere Bedeutung des Internets bemerkte, war Johannes Paul II. In der Botschaft zum Welttag der Massenmedien sprach er über eine „Ära der Computer" und die Verwendung von „computerisierten Beteiligungssystemen“, d. h. Internet, für die Umsetzung der Kirchenmission. ${ }^{5}$. Papst Benedikt XVI. nennt das Internet ein „digitales Kontinent, das zu evangelisieren ist, das jedoch auch evangelisiert ${ }^{6 \text { ", }}$ und Papst Franziskus stellt die Internetmedien als praktische Werkzeuge dar, die an der Kommunikation der Barmherzigkeit teilnehmen können ${ }^{7}$ und weist auch auf damit verbundene Probleme, insbesondere die Fake News oder Deepfakes hin ${ }^{8}$. Sofern die christlichen Internetportale umfangreich über die ekklesische Tätigkeit informieren und sie analysieren, wurden jedoch noch keine breiteren Forschungen der Kirchenanwesenheit im Laienbereich des Internets vorgenommen. Diese Forschung betrifft einen Abschnitt dieser Präsenz in den am meisten besuchten meinungsbildenden Portalen im Inland, die Gegenstand einer ausgefeilten Schlussfolgerung sein sollte. Es betrifft Papst Franziskus und seine apostolischen Reisen im Jahre 2018. Die vorigen Jahre des Pontifikats wurden in den früheren Forschungen analysiert ${ }^{9}$.

${ }^{4}$ J. Kloch, Kościół w Polsce wobec Web 2.0, Kielce 2013, S. 21.

${ }^{5}$ Siehe Johannes Paul II., Orędzie na 24. Światowy Dzień Środków Społecznego Przekazu, Misja Kościoła w erze komputerów, 24. Januar 1990.

${ }^{6}$ Siehe Benedikt XVI., Orędzie na 43. Światowy Dzień Środków Społecznego Przekazu. Nowe technologie, nowe relacje. Trzeba rozpowszechniać kulturę szacunku, dialogu i przyjaźni, 24. Januar 2009.

${ }^{7}$ Siehe Franziskus, Orędzie na 50. Światowy Dzień Środków Społecznego Przekazu Komunikacja i Miłosierdzie - owocne spotkanie, 24. Januar 2016.

${ }^{8}$ Siehe Franziskus, Orędzie na 52. Światowy Dzień Środków Społecznego Przekazu «Prawda was wyzwoli» (J 8, 32). Fake news a dziennikarstwo pokoju“ 24. Januar 2018; Derselbe, Orędzie na 54. Światowy Dzień Środków Społecznego Przekazu "Abyś opowiadał dzieciom Twoim i wnukom» (Wj 10, 2). Życie tworzy historię", 24. Januar 2020.

${ }^{9}$ Siehe M. Wrzos, Zagraniczne podróże apostolskie, $w$ tym misyjne, papieża Franciszka w najważniejszych krajowych portalach internetowych, cz. I (lata 2013-2014), in: „KulturaMedia-Teologia”, 1 (28) 2017, S. 111-141; Derselbe, Zagraniczne podróże apostolskie, w tym misyjne, papieża Franciszka $w$ najważniejszych krajowych portalach internetowych, cz. II (rok 2015); in: „Kultura-Media-Teologia”, 4 (31) 2017, S. 140-179; Derselbe, Apostolische Auslandsreisen von Papst Franziskus, darunter Missionsreisen, in den wichtigsten nationalen Internetportalen (Jahr 2016), in: „Kultura-Media-Teologia”, 2 (38) 2019, S. 67-114; Derselbe, Apostolische Auslandsreisen von Papst Franziskus, darunter Missionsreisen, in den wichtigsten nationalen Internetportalen (Jahr 2017), in: „Kultura-Media-Teologia”, 4 (39) 2019, S. 159-198. Unter den gesamtpolnischen Medien wird das zu analysierende Portal www.fakt.pl anstatt www.se.pl \#, obwohl das letzte mehr Nutzer hat, aufgrund der Fortsetzung der Forschungen sein. 
Der Forschungsprozess besteht aus zwei Stufen: Die erste ist die Bearbeitung der im Internet veröffentlichten Artikeln mit der Methode einer quantitativ-qualitativen Analyse des Inhalts. Dann nehmen wir eine theologisch-missionswissenschaftliche Analyse der erhaltenen Daten vor und ziehen pastorale Schlussfolgerungen. Die Forschungsarbeiten teilen wir in Folgendes:

1. Inhaltsanalyse der Artikeln über die Reisen, darunter Missionsreisen von Papst Franziskus (2018) in den wichtigsten Portalen im Inland mit der quantitativ-qualitativen Methode. Die gesammelten Artikeln betreffen die folgenden Pilgerreisen:
a. 15.-21. Januar - Chile, Peru;
b. 21. Juni - die Schweiz;
c. 25.-26. August - Irland;
d. 22.-25. September - Litauen, Lettland, Estland;

\section{Theologen der sozialen Kommunikationsmittel weisen darauf hin, dass obwohl bis vor Kurzem „die Kirche Missionen führte und das Korn des Evangeliums vom Kontinent zum Kontinent übertrug, betritt sie um die Wende des 20. und 21. Jahrhunderts nach Geburt Christi einen ganz „neuen Boden“.}

2. theologische Analyse der veröffentlichten Inhalte;

3. pastorale Schlussfolgerungen und Antwort auf die Forschungshypothesen, a.) Die Medien in Polen informieren sachgemäß über die Auslandspilgerreisen von Papst Franziskus (quantitativ und qualitativ); b.) Die Vorbereitung der Geistlichen zur Benutzung neuer Medien und zur Benachrichtigung über die mit der Kirche verbundenen Fragen ist sachgemäß; c.) Die Anzahl der Informationen und die Benachrichtigungsart über die Auslandspilgerreisen ist ungenügend. 


\section{INHALTSANALYSE DER IN DEN WICHTIGSTEN PORTALEN VERÖFFENTLICHTEN ARTIKELN ÜBER DIE MISSIONSREISEN VON PAPST FRANZISKUS (2018) MIT DER QUANTITATIV-QUALITATIVEN METHODE}

\begin{tabular}{|c|c|}
\hline \multicolumn{2}{|c|}{ Methodologie der ersten Stufe der Forschungen } \\
\hline - Analysierte Zeit: & $\begin{array}{l}\text { a. 15. Oktober } 2017 \text { - 21. April 2018; } \\
\text { b. 21. März } 2018 \text { - 21. September 2018; } \\
\text { c. 25. Mai } 2018 \text { - 26. November 2018; } \\
\text { d. 22. Juni } 2018 \text { - 25. Dezember 2018; } \\
\text { Drei Monate vor und drei Monate nach den päpstlichen Pilgerreisen; }\end{array}$ \\
\hline - Analysierte Dienste: & $\begin{array}{l}\text { www.onet.pl; www.wp.pl; www.interia.pl; www.gazeta.pl; www. } \\
\text { o2.pl und www.fakt.pl; }\end{array}$ \\
\hline - Inhaltsquellen: & Newspoint \\
\hline - Tiefe der Analyse: & $\begin{array}{l}\text { verbunden (automatisch und manuell) - in den erhaltenen Ergebnissen } \\
\text { der automatischen Suche nach den programmierten Algorithmen erfolgt } \\
\text { Selektion der Wahlrichtigkeit durch den Forscher. }\end{array}$ \\
\hline - Sprache der Quellen: & Polnisch \\
\hline - Sprache der Suche: & Polnisch \\
\hline $\begin{array}{l}\text { - Filtern von Spam/ } \\
\text { Boot-Dateien: }\end{array}$ & $\begin{array}{l}\text { verbunden (automatisch und manuell) - in den erhaltenen Ergebnissen } \\
\text { der automatischen Suche nach den programmierten Algorithmen erfolgt } \\
\text { Selektion der Wahlrichtigkeit durch den Forscher; }\end{array}$ \\
\hline $\begin{array}{l}\text { - Schlüsselfragen/-wör- } \\
\text { ter: }\end{array}$ & 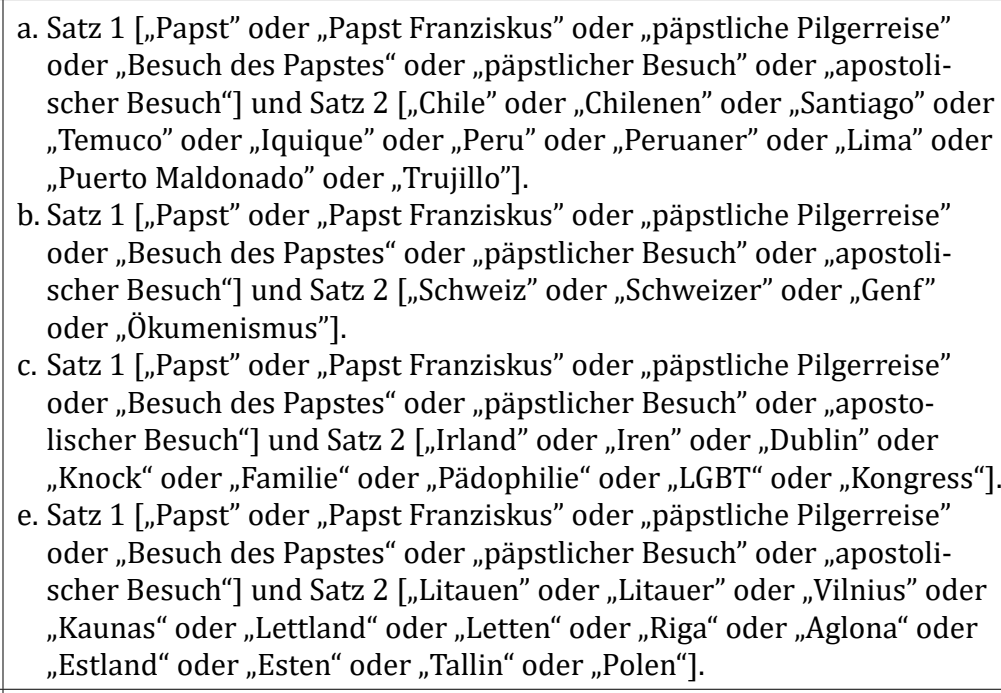 \\
\hline - Analyseeinheit: & $\begin{array}{l}\text { beliebiges Wort aus Satz } 1 \text { zzg. beliebiges Wort als Satz 2, in beliebiger } \\
\text { Sprachversion; }\end{array}$ \\
\hline - Auswertung: & $\begin{array}{l}\text { verbunden (automatisch und manuell) - in den erhaltenen Ergebnissen } \\
\text { der automatischen Suche nach den programmierten Algorithmen (positiv, } \\
\text { neutral, negativ) erfolgt Selektion der Wahlrichtigkeit durch den Forscher; }\end{array}$ \\
\hline
\end{tabular}




\begin{tabular}{l|l} 
- Anzahl der analysierten & a. $70 ;$ \\
Artikeln: & b. $10 ;$ \\
& c. $40 ;$ \\
& d. $54 ; \Sigma=174$.
\end{tabular}

\subsection{5.-21. Januar - Chile, Peru}

Die apostolische Reise von Papst Franziskus nach Chile und Peru fand vom 15. bis zum 21. Januar 2018 statt und es war der 22. päpstliche Besuch. Die Reise nach Chile verlief nach dem Motto: „Meinen Frieden gebe ich euch“ und nach Peru „Geeint in der Hoffnung“. In Chile besuchte der Papst Santiago de Chile, Temuco und Iquique, und in Peru Lima, Puerto Maldonado und Trujillo. Franziskus war der zweite Papst, der Chile und Peru besuchte. Vor ihm besuchte Chile Johannes Paul II vom 1. bis zum 6. April 1987, hingegen besuchte er Peru zweimal: 1.-5. Februar 1985 sowie 14.-16. Mai 1988.

In den analysierten Portalen wurden 70 Texte zu diesem Thema veröffentlicht. Der erste waren die Agenturnachrichten vom 10. Januar 2018 im Portal www.onet.pl. Sie betrafen sexuelle Missbräuche gegenüber Minderjährigen in

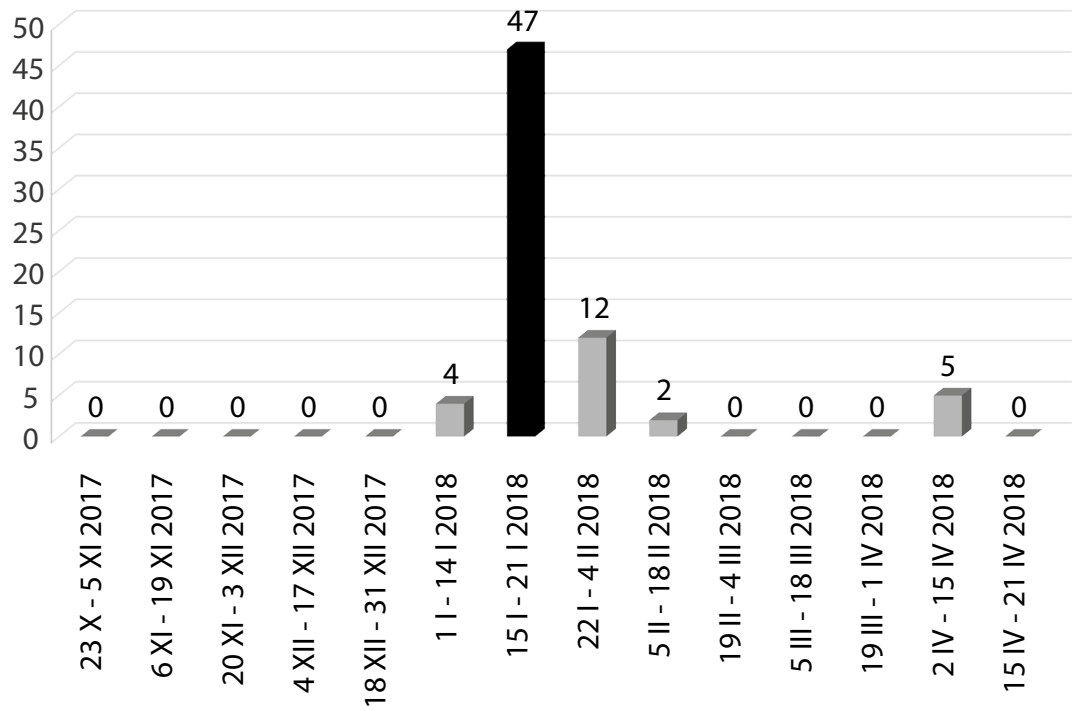

Diagramm Nr. 1. Anzahl der Publikationen zum Thema des Besuchs von Papst Franziskus in Chile und Peru in den polnischen Portalen nach dem Veröffentlichungstag, $\mathrm{N}=70$

Quelle: Newspoint 
einem der katholischen Vereine. Das Problem wurde im Zusammenhang mit der schnellen Reaktion des Apostolischen Stuhls aufgrund der näher kommenden Reise von Papst Franziskus dargestellt. Die Information wurde durch die Redaktion doppelt gemacht. Die letzte Publikation erschien am 13. April 2018, auch im Portal www.onet.pl und betraf die Notwendigkeit des Rücktritts des Episkopats von Chile im Zusammenhang mit den Missbräuchen in der Kirche und mit der Reaktion auf die Vorwürfe gegen Bischöfe des Papstes nach der Pilgerreise nach diesem Land. Die direkt mit der Pilgerreise verbundenen Berichte wurden während ihrer Dauer veröffentlicht. Es waren am häufigsten Pressemitteilungen bzw. ihre Kommentare (59). Es gab 4 veröffentlichte Nachrichten in der Zeit vor der päpstlichen apostolischen Reise und 19 danach. Die letzten davon wurde drei Monate nach ihrer Beendigung veröffentlicht und waren mit dem Episkopat von Chile verbunden.

Die meisten Nachrichten zum Thema der päpstlichen Pilgerreise nach Chile und Peru veröffentlichte das Portal www.onet.pl (23), was ihm rund 33\% des
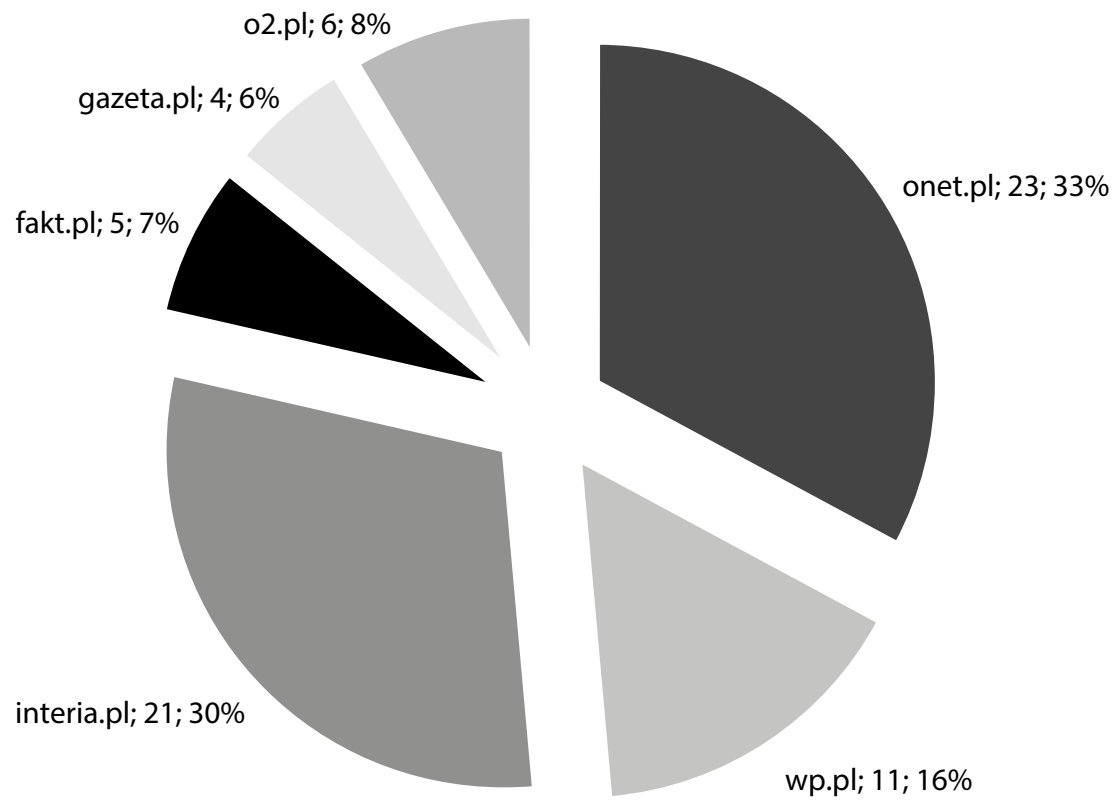

Diagramm Nr. 2. Anzahl der Publikationen zum Thema des Besuchs von Papst Franziskus in Chile und Peru in den polnischen Portalen nach dem Veröffentlichungsort, $\mathrm{N}=70$

Quelle: Newspoint 
Anteils am Markt der Internetnachrichten zu diesem Thema ausmacht. Die weiteren Portale unter Berücksichtigung der Publikationsanzahl waren entsprechend: www.interia.pl (21), www.wp.pl (11), www.o2.pl (6), www.fakt.pl (5), und am wenigsten veröffentlichte das Portal www.gazeta.pl (4). Im Falle des Portals www.gazeta.pl erschienen einzelne Nachrichten während der Pilgerreise. Derzeit sind sie nicht mehr im Portal verfügbar.

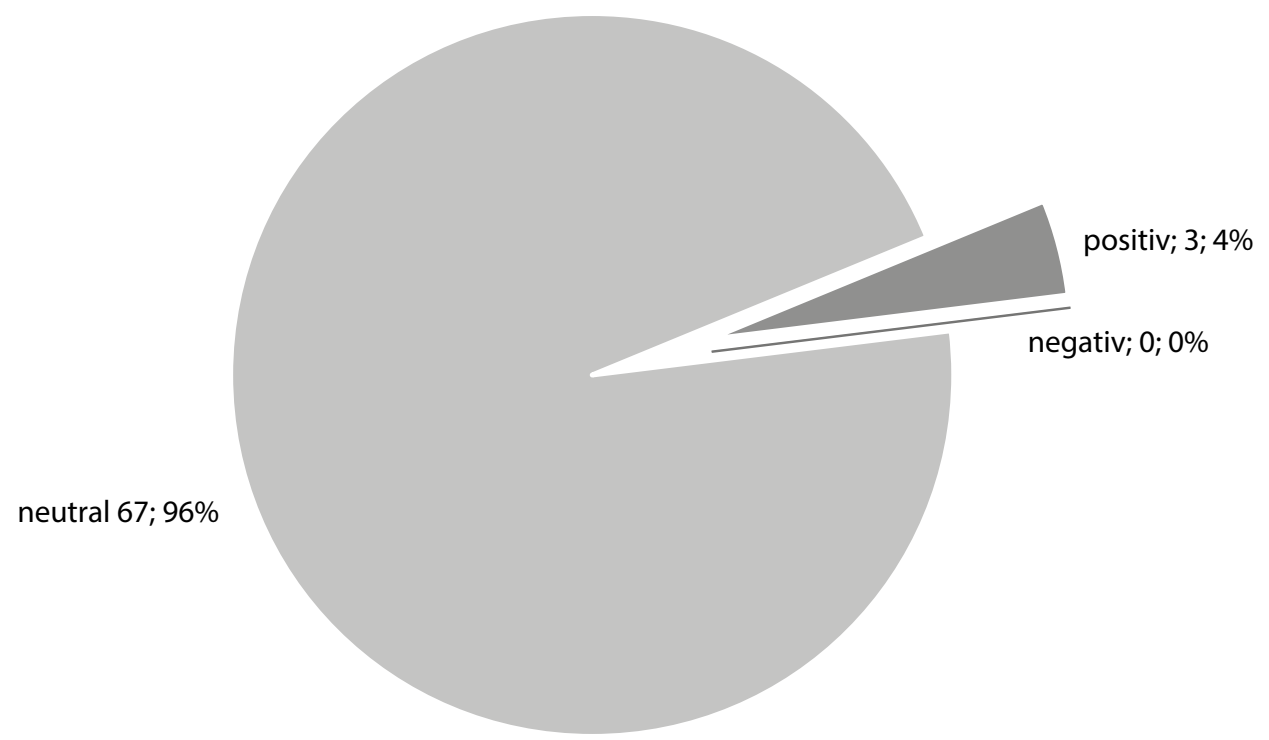

Diagramm Nr. 3. Anzahl der Publikationen zum Thema des Besuchs von Papst Franziskus in Chile und Peru in den polnischen Portalen nach der Veröffentlichungsart, N=70 Quelle: Newspoint

Weitere Stufe der auszuführenden Forschungen war Ermittlung der Kommunikationsweise über diese apostolische Pilgerreise von Papst Franziskus. Aus den durchgeführten Forschungen geht es hervor, dass von 70 der veröffentlichten Nachrichten positiv (3) bzw. neutral waren (67). Negative Informationen, auch über sexuelle Missbräuche, die die Kirche eindeutig herabmindern würden, gab es nicht. Die Autoren zeigten damals die Gegenwirkung von Papst Franziskus. Es hängt unter anderem damit zusammen, dass es sich bei den meisten Publikationen um Agenturmitteilungen von Informationsnatur handelt. 
Das Zahlenverhältnis der positiven und negativen zum Thema der besprochenen Pilgerreise im gegeben analysierten Medium veröffentlichten Nachrichten ist aufgrund dessen, dass es lediglich neutrale Nachrichten waren, identisch.

Die meisten geforschten Internetportale bedienen sich der Mitteilungen der Polnischen Nachrichtenagentur (PAP), der Katholischen Informationsagentur (KAI), der Rundfunkinformationsagentur (RAI) und von Radio Vatikan (RV).

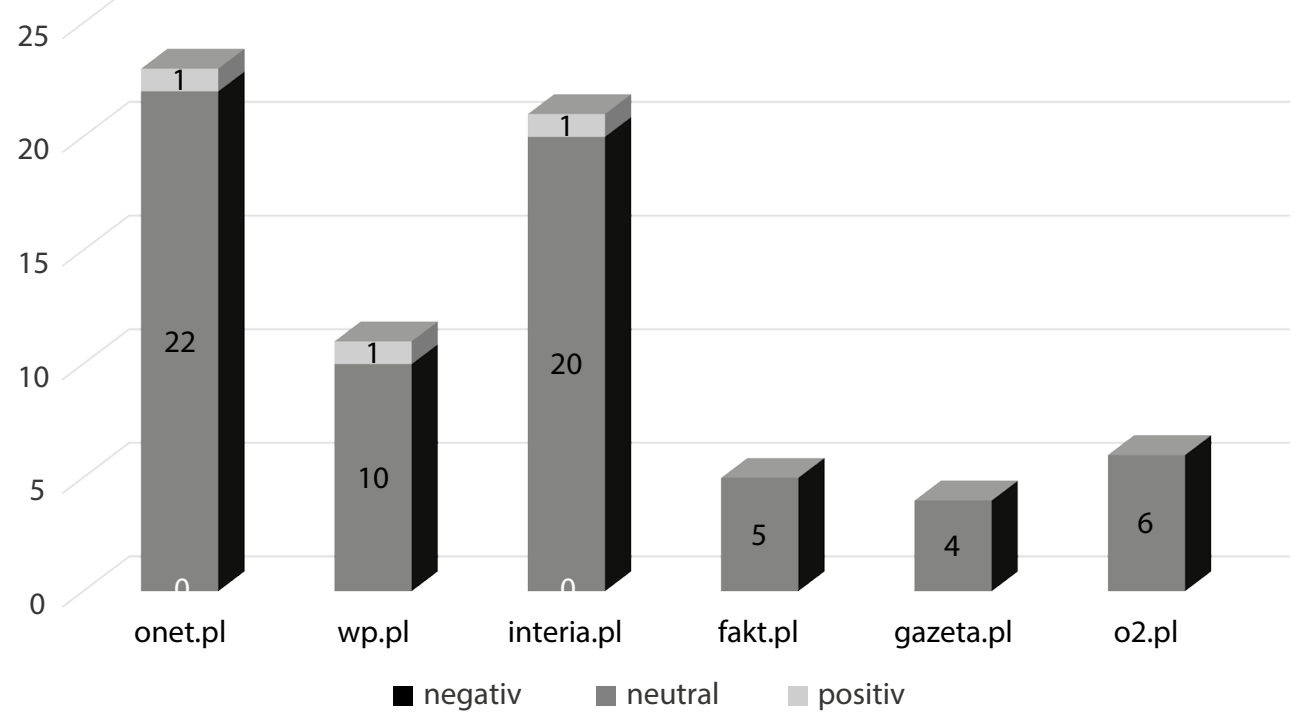

Diagramm Nr. 4. Anzahl der Publikationen zum Thema des Besuchs von Papst Franziskus in Chile und Peru in den polnischen Portalen nach dem Veröffentlichungsort und -art, $\mathrm{N}=70$ Quelle: Newspoint

Die Aussage der Nachrichten war somit neutral. Es gab keine negativen. Materialien, die die Aussage und den Inhalt der päpstlichen Reden vertieften, wurden grundsätzlich nicht veröffentlicht und man konzentrierte sich aufs Problem von sexuellen Missbräuchen in Chile. Die Narration bezüglich dieses Themas dominierte im päpstlichen Besuch (zirka 60\% der mit diesem Thema verbundenen Nachrichten). Während der Pilgerreise konzentrierten sich die Publizisten auf die Äußerungen des Papstes bezüglich der Probleme mit den Missbräuchen in diesen Kirchen, getrauten Stewards im Flugzeug, der Kritik von Kardinälen sowie den Ordnungsunfällen. 


\subsection{Juni - die Schweiz}

Die eintägige apostolische Reise von Papst Franziskus nach der Schweiz fand am 21. Juni 2018 statt. Während des Besuchs besuchte der Papst den Weltkirchenrat in Genf. Es war der zweite Besuch des katholischen Kirchenvorstehers in diesem Land und in dieser Organisation. Früher besuchte Johannes Paul II sie im Jahre 1984.

In den analysierten Portalen wurden 10 Texte zum Thema dieses Besuchs veröffentlicht. Der erste war die Nachricht am Tag der Pilgerreise - 21. Juni 2018 im Portal www.interia.pl. Die letzte Veröffentlichung erschien sechs Tage später, am 27. Juni 2018 im gleichen Internetmedium. Die Publizisten kommentierten die päpstliche Pilgerreise im Zusammenhang mit dem Ökumenismus und seelsorgerischen Aktionen betreffend die Einheit der Christen. Die mit der Pilgerreise verbundenen Informationen erschienen am Tag der Pilgerreise. Es wurden Agenturnachrichten sowie Bilderberichte veröffentlicht (10). In der Zeit vor der päpstlichen apostolischen Reise wurden keine und danach drei Informationen veröffentlicht.

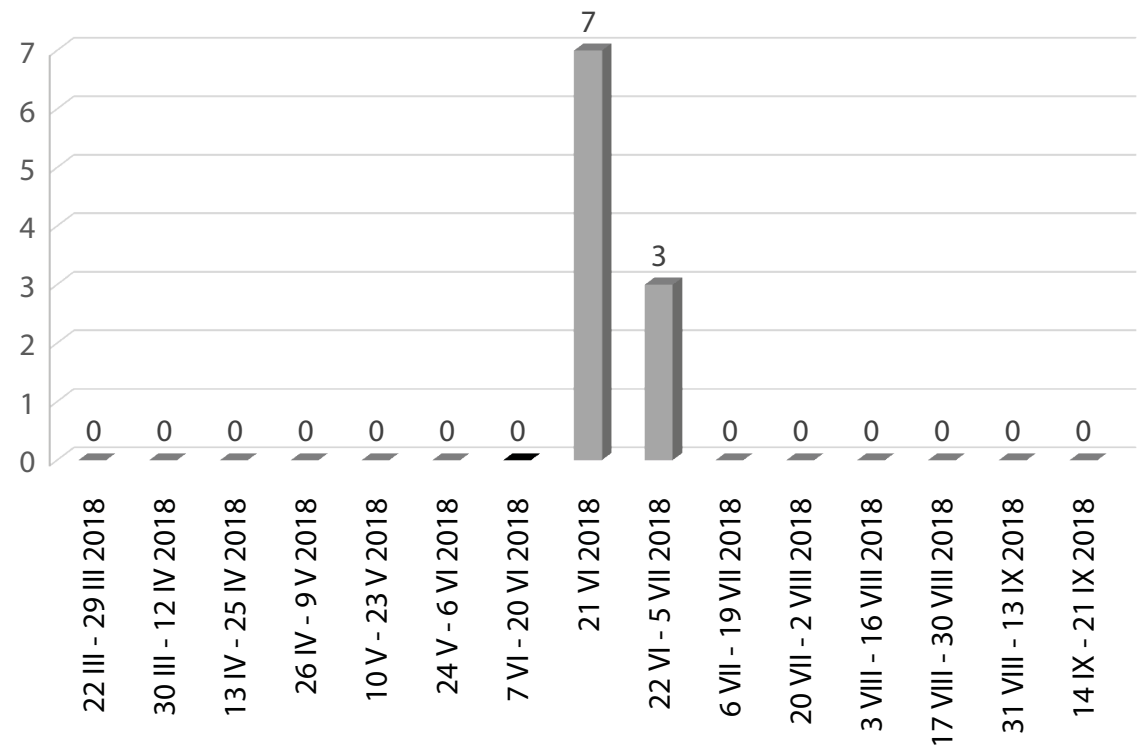

Diagramm Nr. 5. Anzahl der Publikationen zum Thema des Besuchs von Papst Franziskus in der Schweiz in den polnischen Portalen nach dem Veröffentlichungstag, $\mathrm{N}=10$

Quelle: Newspoint 
Die meisten Nachrichten zum Thema der päpstlichen Pilgerreise nach der Schweiz veröffentlichte das Portal www.interia.pl (8), was ihm rund $80 \%$ des Anteils am Markt der Internetnachrichten ausmacht. Die weiteren Portale unter Berücksichtigung der Publikationsanzahl waren entsprechend: www.onet.pl (2). Die übrigen Internetportale benachrichtigten darüber nicht.

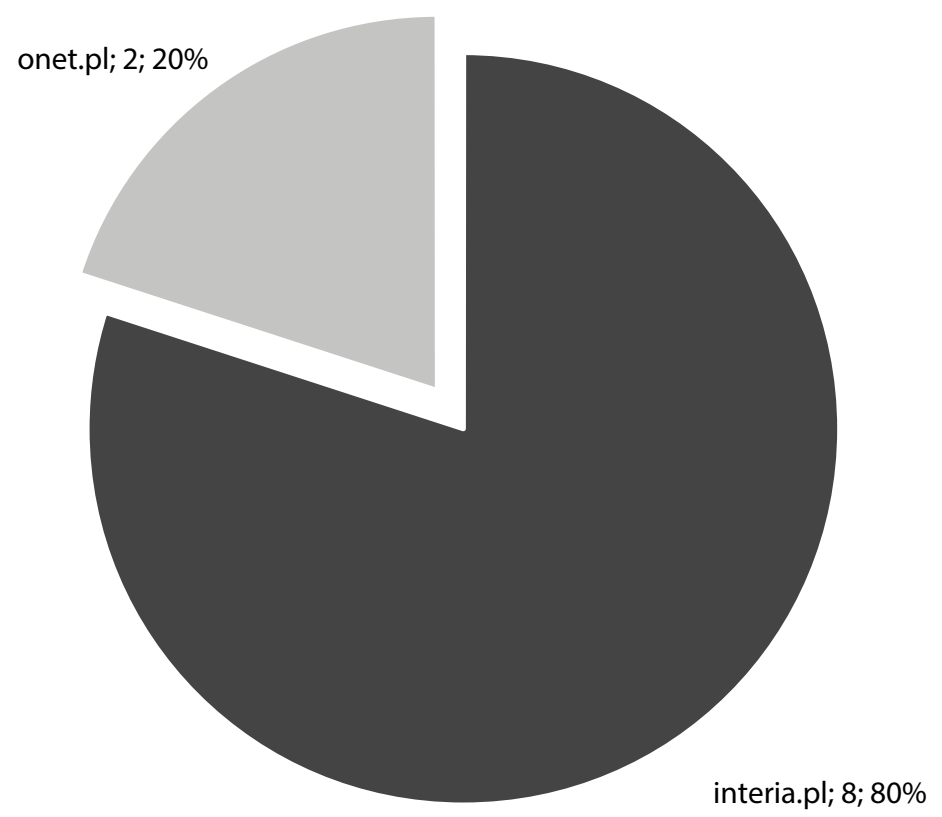

Diagramm Nr. 6. Anzahl der Publikationen zum Thema des Besuchs von Papst Franziskus in der Schweiz in den polnischen Portalen nach dem Veröffentlichungsort, $\mathrm{N}=10$

Quelle: Newspoint

Weitere Stufe der auszuführenden Forschungen war Ermittlung der Kommunikationsweise über diese apostolische Pilgerreise von Papst Franziskus. Aus den durchgeführten Forschungen geht es hervor, dass 9/10 der veröffentlichten Nachrichten neutral und eine negativ waren. Es betraf den Aufruf von Papst Franziskus zur Annahme von Immigranten.

Das Zahlenverhältnis der positiven und negativen zum Thema der besprochenen Pilgerreise Nachrichten ist aufgrund dessen, dass es lediglich neutrale bzw. positive Nachrichten waren, identisch. 


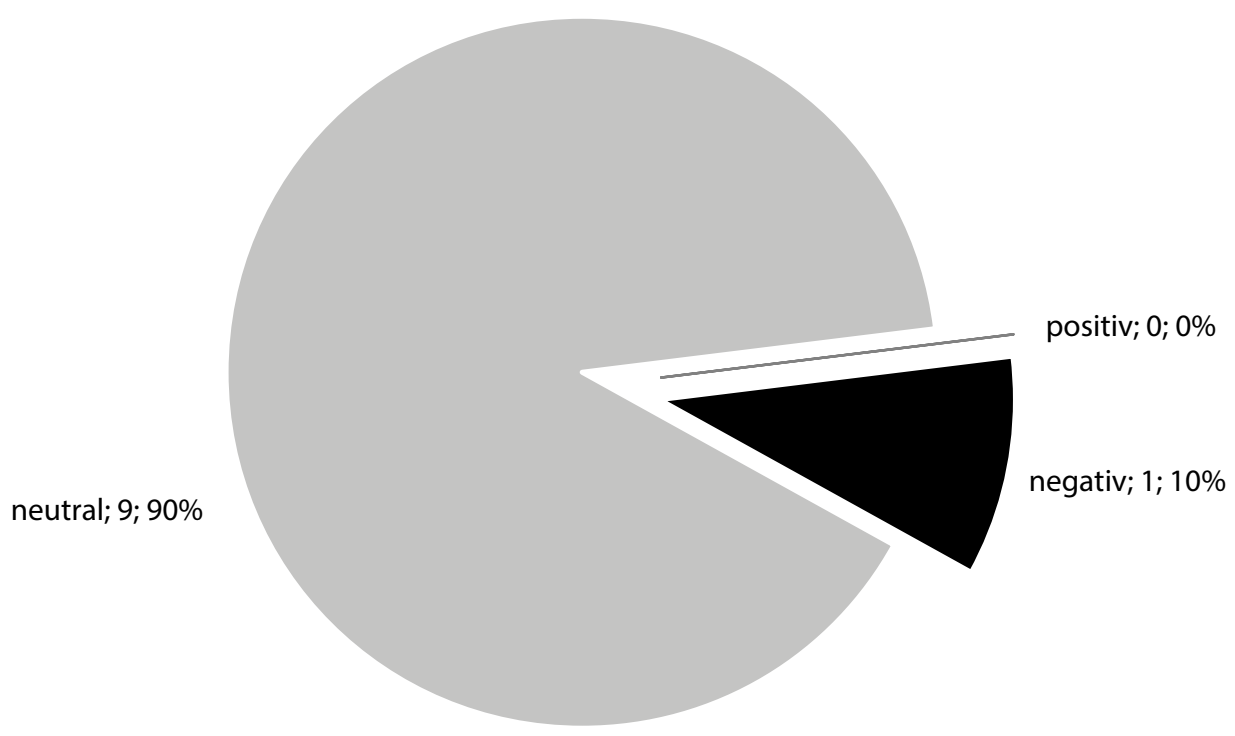

Diagramm Nr. 7. Anzahl der Publikationen zum Thema des Besuchs von Papst Franziskus in der Schweiz in den polnischen Portalen nach der Veröffentlichungsart, $\mathrm{N}=10$ Quelle: Newspoint

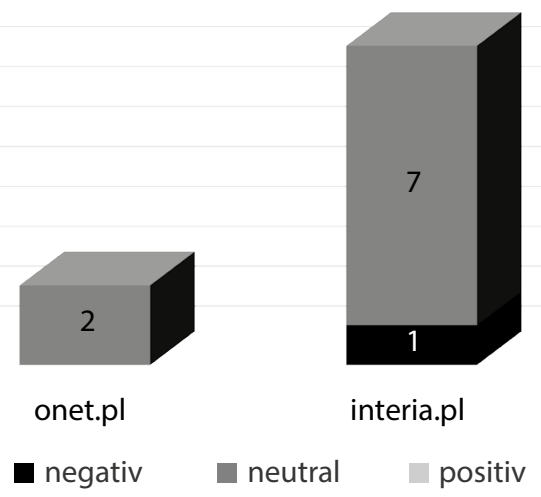

Diagramm Nr. 8. Anzahl der Publikationen zum Thema des Besuchs von Papst Franziskus in der Schweiz in den polnischen Portalen nach dem Veröffentlichungsort und -art, $\mathrm{N}=10$

Quelle: Newspoint

Die meisten geforschten Internetportale bedienen sich der Mitteilungen aus den Diensten PAP, KAI, RAI und RV bzw. Bildreportage. Die Aussage der 
Nachrichten war in neutral, ohne Angabe des Autors. Es gab keine negativen Nachrichten oder Kommentare. Materialien, die die Aussage und den Inhalt der päpstlichen Reden vertieften, wurden eher nicht veröffentlicht. Während der Pilgerreise konzentrierten sich die Publizisten auf die Äußerungen des Papstes bezüglich des Ökumenismus und der Immigranten.

\subsection{5.-26. August - Irland}

Die apostolische Reise von Papst Franziskus nach Irland fand vom 25. bis zum 26. August 2018 statt. Es war der vierundzwanzigste Pilgerreise des aus Argentinien stammenden Papstes. Während der Pilgerreise nahm der Papst an der Beendigung des 9. Weltfamilientreffens teil. Franziskus war der zweite Papst, der Irland besuchte; vor ihm besuchte Irland einmal Johannes Paul II im Jahre 1979.

Auf den analysierten Webseiten wurden 54 Texte zum Thema dieses Besuchs veröffentlicht. Die ersten waren die Informationen vom 25. zum 28. Mai 2018 im Portal www.onet.pl. Sie betrafen die in Irland durchgeführte Volksabstimmung, in der die Einwohner ihre Zustimmung gaben, die Eintragung über den Lebensschutz von Kindern ab Empfängnis zu löschen, somit Zustimmung zur Abtreibung.

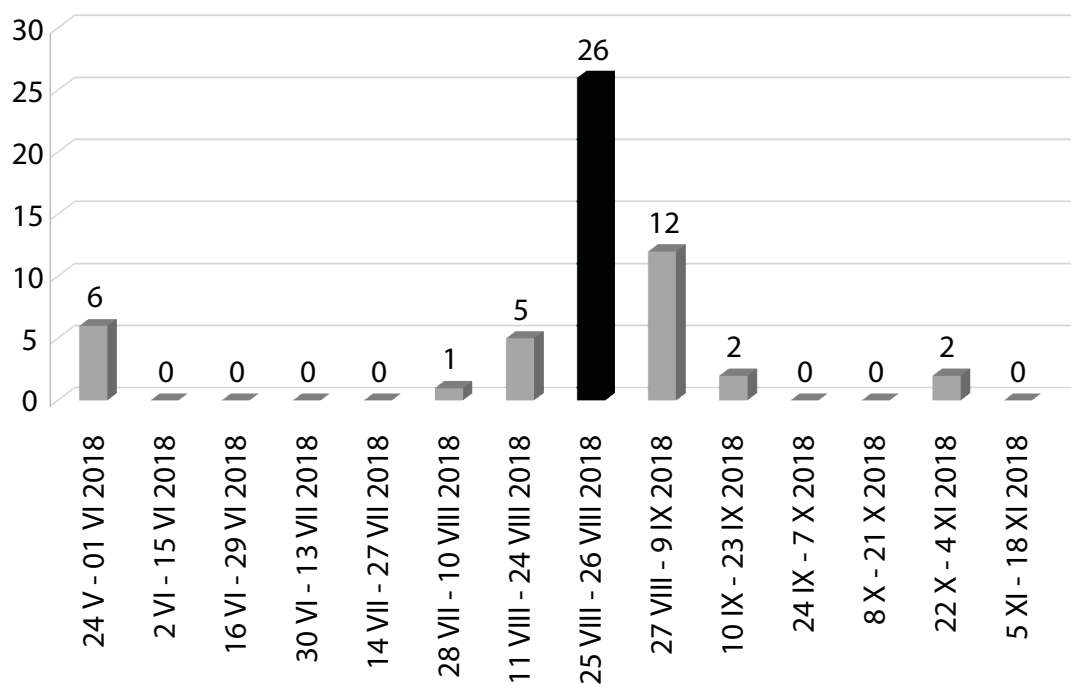

Diagramm Nr. 9. Anzahl der Publikationen zum Thema des Besuchs von Papst Franziskus in Irland in den polnischen Portalen nach dem Veröffentlichungstag, $\mathrm{N}=54$ Quelle: Newspoint 
Die Autoren zeigten dieses Ereignis im Zusammenhang mit der näher kommenden Pilgerreise von Papst Franziskus nach diesem Land. Die letzte Publikation erschien am 27. Oktober 2018 im Portal www.wp.pl. Der Autor beschäftigt sich mit der Offenbarung weiterer Verdachte hinsichtlich der Missbräuche von Minderjährigen, die in den katholischen Schulen in diesem Land stattfinden sollten. Über die Situation berichtet er als Fortsetzung des vom Papst bestimmten Vorgehens, das anstrebt, die Täter dieser Verbrechen zu entdecken und zu verurteilen, was er während der Pilgerreise nach diesem Land betonte. Die mit der Pilgerreise verbundenen Berichte wurden während ihrer Dauer und der letzte zwei Tage danach veröffentlicht. Sie betrafen am meisten die päpstliche Lehre zum Thema der Familie, der Immigranten und auch der sexuellen Missbräuche - die Narration über die letzten dominierte die mediale Übertragung. Es wurden am häufigsten Pressemitteilungen veröffentlicht (43). Es wurden 12 Nachrichten vor der päpstlichen apostolischen Reise und 16 danach veröffentlicht.

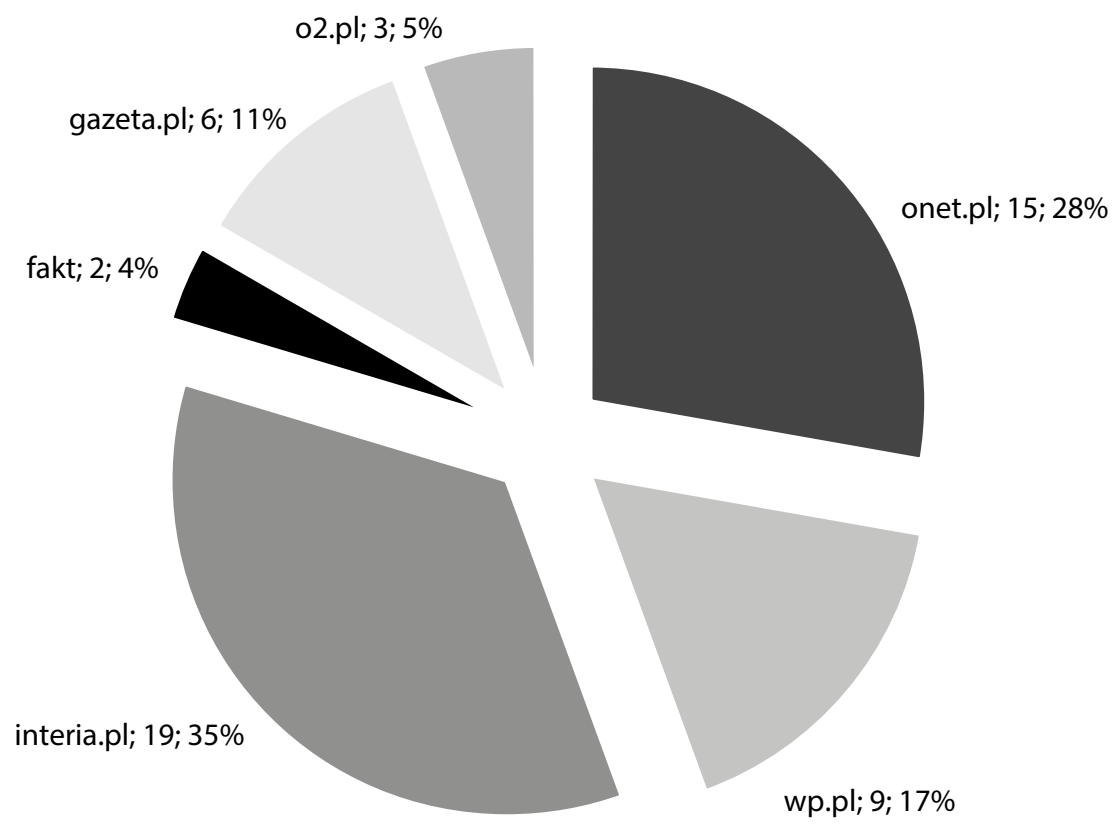

Diagramm Nr. 10. Anzahl der Publikationen zum Thema des Besuchs von Papst Franziskus in Irland in den polnischen Portalen nach dem Veröffentlichungsort, $\mathrm{N}=54$

Quelle: Newspoint 
Die meisten Nachrichten zum Thema der päpstlichen Pilgerreise nach Irland veröffentlichte das Portal www.interia.pl (19), was ihm rund 35\% des Anteils am Markt der Internetnachrichten ausmacht. Die weiteren Portale unter Berücksichtigung der Publikationsanzahl waren entsprechend: www.onet.pl (15), www. wp.pl (9), www.gazeta.pl (6), www.o2.pl (3) und www.fakt.pl (2).

Weitere Stufe der auszuführenden Forschungen war Ermittlung der Kommunikationsweise über diese apostolische Pilgerreise von Papst Franziskus. Aus den durchgeführten Forschungen geht es hervor, dass 49/54 der veröffentlichten Nachrichten positiv (3) bzw. neutral waren (46). Es wurden 5 negative Kommentare veröffentlicht. Mit Ausnahme von einem betreffen sie nicht Papst Franziskus selbst sondern die Kirche, die als eine Gemeinschaft dargestellt wurde, die nicht im Kampf gegen die Kriminalität hinsichtlich der sexuellen Missbräuche von Minderjährigen engagiert ist.

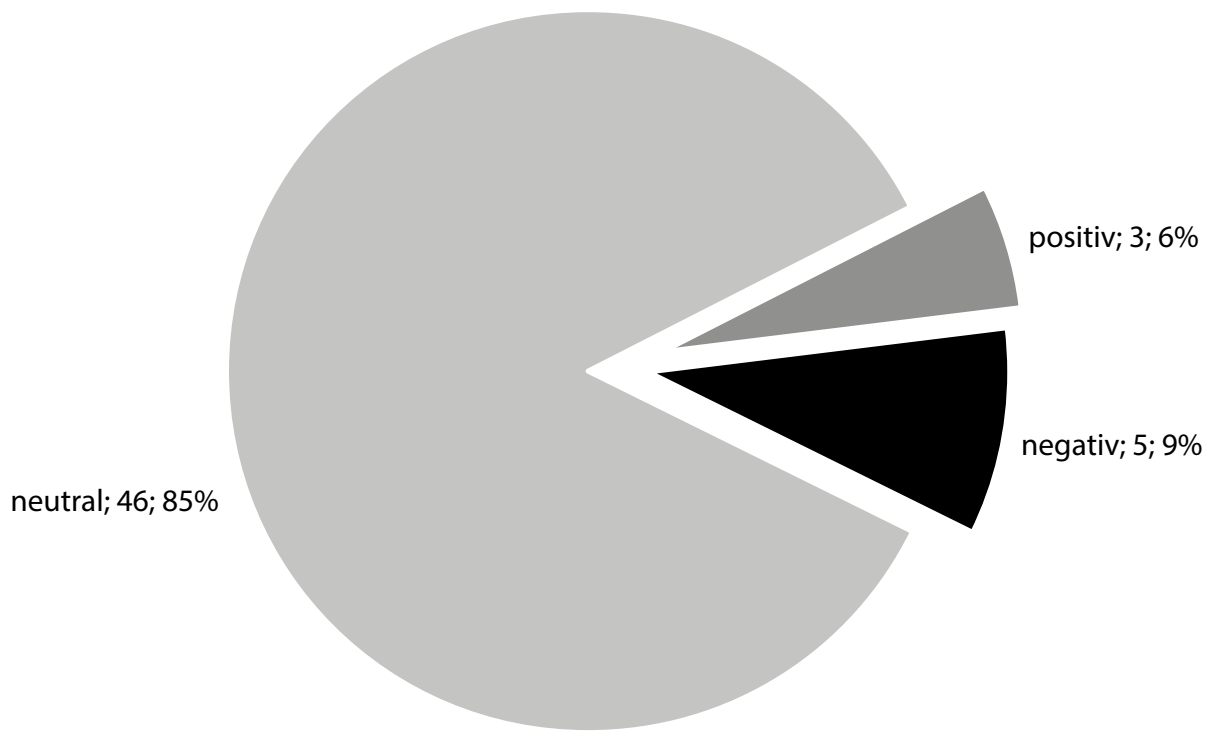

Diagramm Nr. 11. Anzahl der Publikationen zum Thema des Besuchs von Papst Franziskus in Irland in den polnischen Portalen nach der Veröffentlichungsart, N=54 Quelle: Newspoint

Der Anteil an negativen, positiven und neutralen Nachrichten war unter den analysierten Portalen vergleichbar. Die meisten negativen Informationen wurden im Portal www.onet.pl veröffentlicht. 


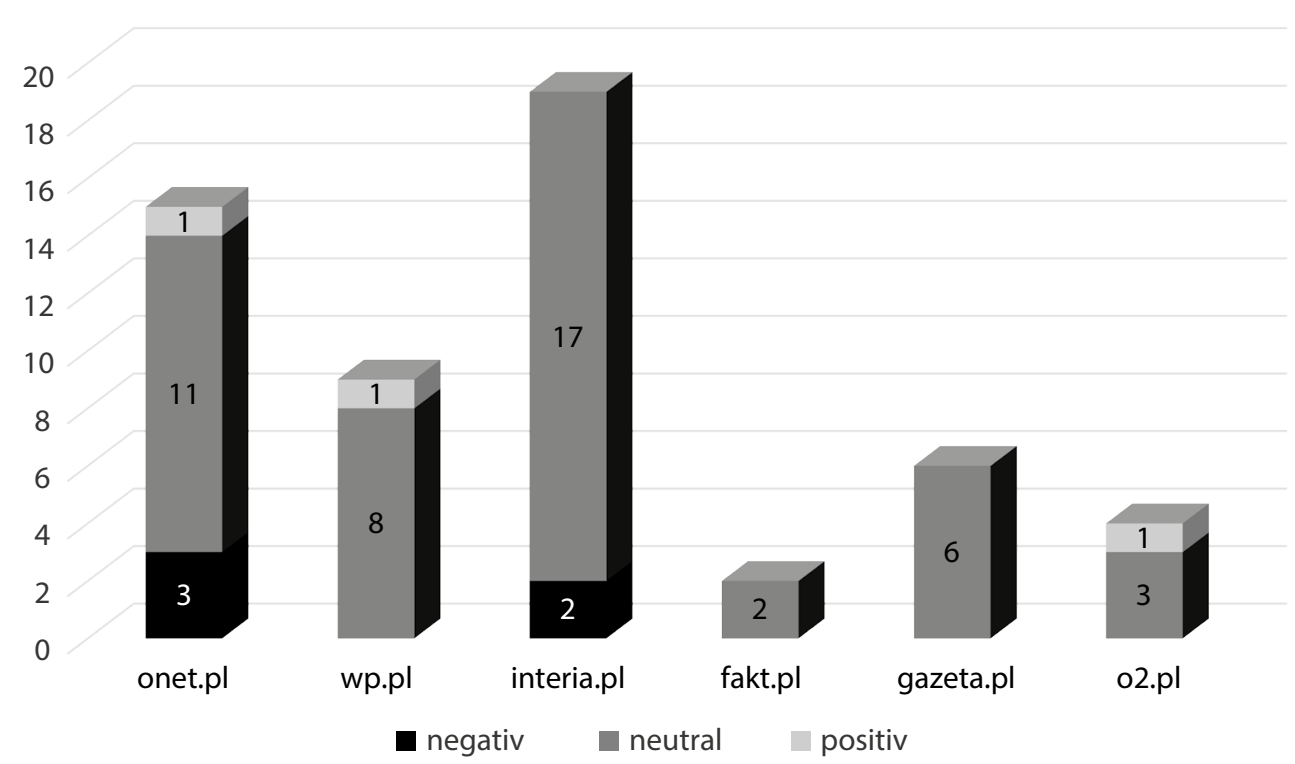

Diagramm Nr. 12. Anzahl der Publikationen zum Thema des Besuchs von Papst Franziskus in Irland in den polnischen Portalen nach dem Veröffentlichungsort und -art, N=54

Quelle: Newspoint

So wie während der analysierten Zeit der zwei ersten Pilgerreisen bedienen sich die meisten geforschten Internetportale der Mitteilungen aus den Diensten PAP, KAI, RAI und RV. Die Aussage der Nachrichten war in der Regel neutral, ohne Angabe des Autors. Die negativen Nachrichten betrafen kein Engagement der Kirche und laut den Autoren des Bischofs von Rom in die Bestrafung der in sexuelle Verbrechen gegenüber Minderjährigen verwickelten Geistlichen. Materialien, die die Aussage und den Inhalt der päpstlichen Reden vertieften, wurden wenig veröffentlicht. Am häufigsten waren sie mit dem obigen Thema sowie mit der Legalisierung von homosexuellen Ehen in Irland verbunden. Thema des 9. Weltfamilientreffens wurde, wie es scheint, in geringem Maße vernommen.

\subsection{2.-25. September - Litauen, Lettland, Estland}

Die letzte apostolische Reise von Papst Franziskus im Jahre 2018 fand in Litauen, Lettland und Estland vom 22. bis zum 25. September 2018 statt. Die Pilgerreise nach Litauen erfolgte unter dem Motto: „Jesus Christus - unsere Hoffnung“, nach Lettland: „Zeige, dass du Mutter bist“ und nach Estland: „Erwecke mein Herz“. In Litauen besuchte der Papst Vilnius und Kaunas, in Lettland Riga und Aglona und 
in Estland Tallinn. Dieser Besuch war 25 Jahre nach der ersten Auslandsreise von Johannes Paul II. nach den baltischen Ländern, der im Jahre 1993 stattfand.

In den analysierten Portalen wurden 40 Texte zum Thema dieses Besuchs veröffentlicht. Der erste war die Nachricht vom 22. September 2018 im Portal www.onet.pl. Es war die Information darüber, dass Papst Franziskus auf dem Weg nach Litauen ist und dass er ein Telegramm an Polen sendet. Früher veröffentlichten die Medien keine Informationen zur Pilgerreise. Die letzte Publikation erschien am 15. November 2018 im Portal www.interia.pl und war mit der verabschiedeten Amnestie anlässlich des hundertsten Jahrestags der Wiedererlangung der Unabhängigkeit durch Litauen und des Besuchs von Papst Franziskus in dem Land verbunden. Die mit der Pilgerreise verbundenen Berichte wurden während ihrer Dauer und der letzte zwei Tage danach veröffentlicht. Sie betrafen am meisten die päpstliche Lehre zum Thema des Friedens, des Holocausts, der sexuellen Missbräuche in der Kirche. Es wurden am häufigsten Pressemitteilungen veröffentlicht (36). In der Zeit vor der päpstlichen apostolischen Reise wurden keine und danach vier Informationen veröffentlicht. Die negativen Informationen wurden nach Beendigung des Besuchs von Franziskus in den baltischen

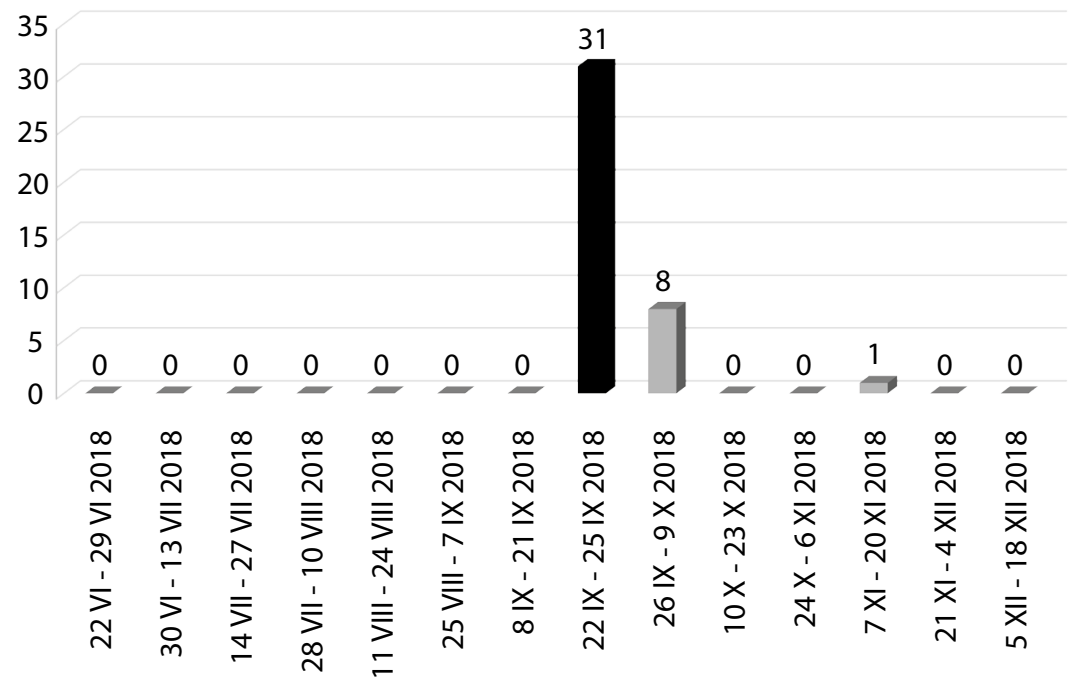

Diagramm Nr. 13. Anzahl der Publikationen zum Thema des Besuchs von Papst Franziskus in Litauen, Lettland und Estland in den polnischen Portalen nach dem Veröffentlichungstag, $\mathrm{N}=40$

Quelle: Newspoint 
Ländern veröffentlicht. Es wurde der Protest von Maciej Świrski, Präsidenten von Redoute des Guten Namens, gerichtet an Papst Franziskus veröffentlicht, in dem er Einspruch gegen eine seiner Aussagen einlegt. Sie betraf die Rolle Polens in der Geschichte Litauens.

Die meisten Nachrichten zum Thema der päpstlichen Pilgerreise nach Litauen, Lettland und Estland veröffentlichte das Portal www.interia.pl (22), was ihm rund 55\% des Anteils am Markt der Internetnachrichten ausmacht. Die weiteren Portale unter Berücksichtigung der Publikationsanzahl waren entsprechend: www.onet.pl (7), www.gazeta.pl (4), www.fakt.pl (4) und www.wp.pl (1). Im Portal www.o2.pl erschienen keine Nachrichten.

Weitere Stufe der auszuführenden Forschungen war Ermittlung der Kommunikationsweise über diese apostolische Pilgerreise von Papst Franziskus. Aus den durchgeführten Forschungen geht es hervor, dass 38/40 der veröffentlichten Nachrichten neutral (37) oder positiv (3) waren. Es wurden zwei negative Informationen veröffentlicht.

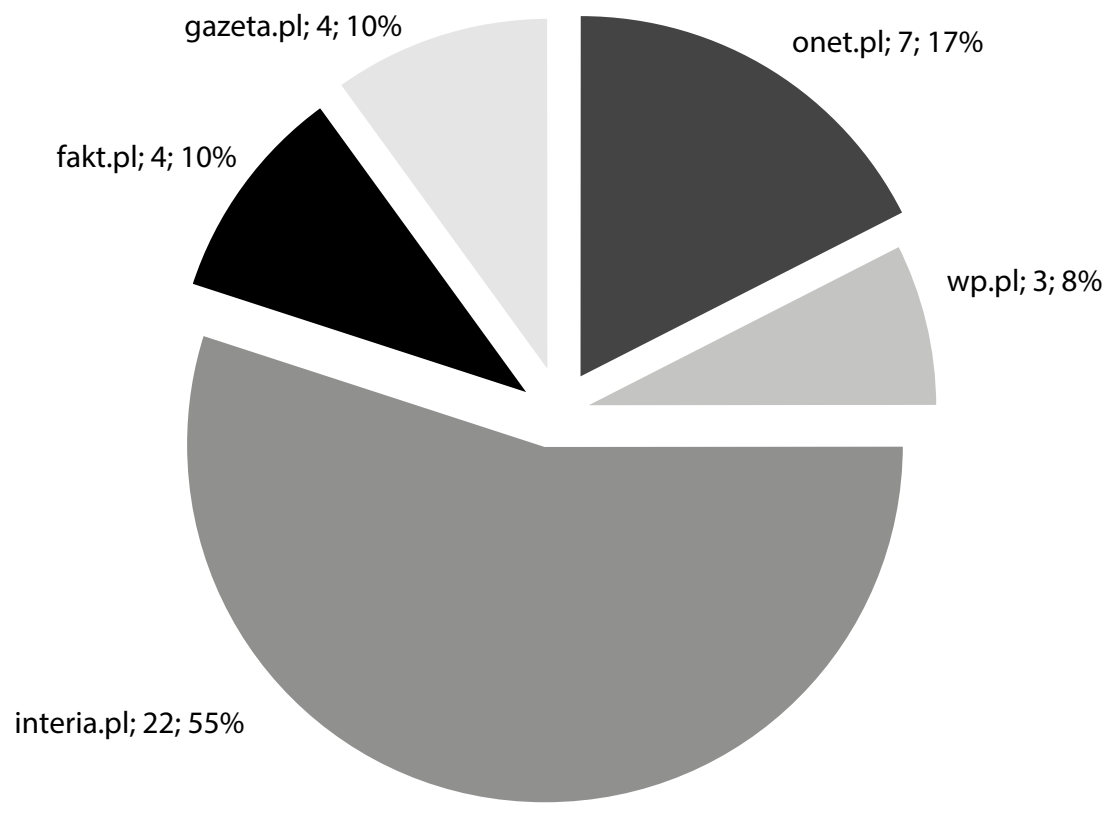

Diagramm Nr. 14. Anzahl der Publikationen zum Thema des Besuchs von Papst Franziskus in Litauen, Lettland und Estland in den polnischen Portalen nach dem Veröffentlichungsort, $\mathrm{N}=40$

Quelle: Newspoint 


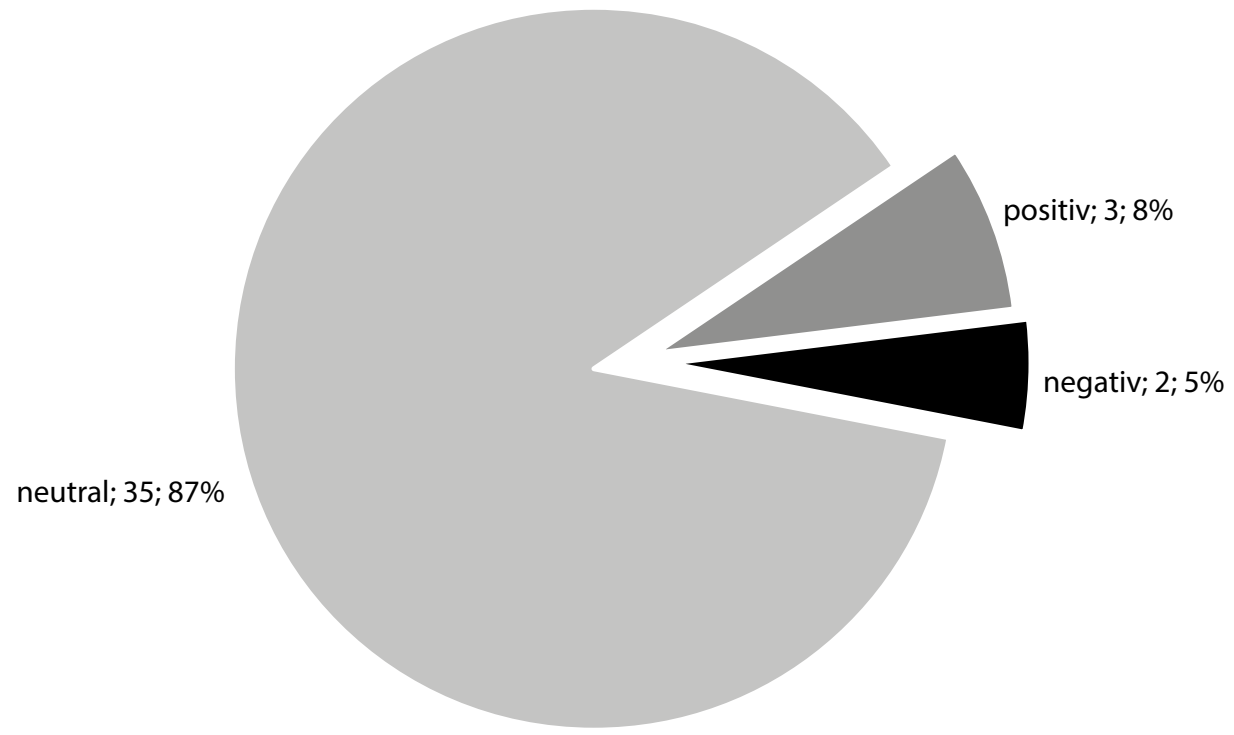

Diagramm Nr. 15. Anzahl der Publikationen zum Thema des Besuchs von Papst Franziskus in Litauen, Lettland und Estland in den polnischen Portalen, $\mathrm{N}=40$ Quelle: Newspoint

Der Anteil an negativen, positiven und neutralen Nachrichten war in der Regel in den analysierten Portalen vergleichbar. Im Portal www.interia.pl wurden die meisten eindeutig positiven Informationen, und auf www.gazeta.pl negativen veröffentlicht.

Die meisten geforschten Internetportale bedienen sich der Mitteilungen aus den Diensten PAP, KAI, RAI und RV, deshalb sind viele Publikationen neutral, nicht emotional geladen. Während der Pilgerreise erschienen ein paar Nachrichten über die Pilgerreise von Papst Franziskus nach Litauen, Lettland und Estland. Der Besuch wurde insbesondere unter Betonung der mit Polen verbundenen Orte, des Holocausts, des Totalitarismus ${ }^{10}$. Zusammenfassungen der Pilgerreise,

${ }^{10}$ Siehe [ohne Autor], Papież Franciszek na Litwie, 22 IX 2018, in: http://www.fakty.interia.pl//swiat/iId,2581575,iAId,306971, [Zugriff: 10. Februar 2020]; [ohne Autor], Litwa: 100 tysięcy osób na papieskiej mszy w Kownie, 23 IX 2018, in: http://www.fakty.interia.pl/ swiat/news-litwa-100-tysiecy-osob-na-papieskiej-mszy-w-kownie,nId,2634906, [Zugriff: 10. Februar 2020]; [ohne Autor], Papież Franciszek na Litwie. Modlił się w dawnych celach KGB, w których torturowano więźniów, 23 IX 2018, in: http://www.wiadomosci.gazeta.pl/wiadomosci/7,114881,23959838,papiez-franciszek-na-litwie-modlil-sie-w-dawnych-celach-kgb. html, [Zugriff: 10. Februar 2020]; [ohne Autor], Papież na kolanach $w$ więziennej celi. Tam 


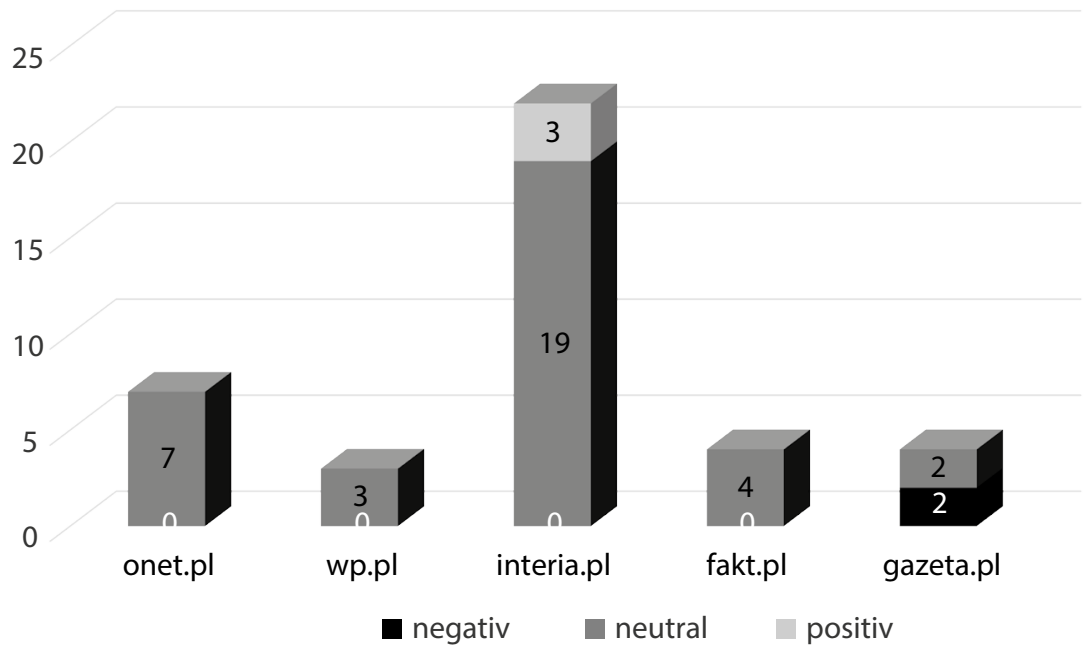

Diagramm Nr. 16. Anzahl der Publikationen zum Thema des Besuchs von Papst Franziskus in Litauen, Lettland und Estland nach dem Veröffentlichungsort und -art, $\mathrm{N}=40$

Quelle: Newspoint

der Reflexionen, darunter theologisch, wurden meistens nicht veröffentlicht. Die einzigen Informationen betrafen die Rolle des Kreuzes und der Barmherzigkeit im christlichen Leben ${ }^{11}$. Die letzten Nachrichten fielen mit dem letzten Tag der Pilgerreise zusammen, obwohl sie aufgrund des Zeitunterschieds ein Tag später veröffentlicht wurden.

\section{THEOLOGISCHE ANALYSE DER VERÖFFENTLICHTEN INHALTE}

Die meisten Nachrichten bezüglich der päpstlichen Pilgereisen waren Agenturnachrichten, am häufigsten nach der Katholischen Informationsagentur (KAI), der Polnischen Nachrichtenagentur (PAP) und der Rundfunkinformationsagentur

bito i torturowano więźniów, 24 IX 2018, in: http://www.fakt.pl/wydarzenia/swiat/papiezfranciszek-na-kolanach-w-wieziennej-celi-w-wilnie-na-litwie/8hqymbt [Zugriff: 10. Februar 2020]; [ohne Autor], Papież w Estonii: Niektórzy grożąc broniq̨ i wojskiem, wydaja się silniejsi, 25 IX 2018, in: http://www.fakty.interia.pl/swiat/news-papiez-w-estonii-niektorzy-grozacbronia-i-wojskiem-wydaja-s,nId,2636038, [Zugriff: 10. Februar 2020].

${ }^{11}$ Siehe [ohne Autor], Litwa: 100 tysięcy osób na papieskiej mszy w Kownie, 23 IX 2018, in: http://www.fakty.interia.pl/swiat/news-litwa-100-tysiecy-osob-na-papieskiej-mszy-w-kownie,nId,2634906, [Zugriff: 10. Februar 2020]. 
(RAI), dem Radio Vatikan (RV) veröffentlicht. Ihre Anzahl beträgt 148 von 174, was $\mathbf{8 5 , 1 \%}$ der gesamten Informationen darstellt. Es sind Inhalte, die ohne Angabe des Autors und dupliziert ohne Beurteilung des jeweiligen Ereignisses bzw., am häufigsten, der päpstlichen Lehre veröffentlicht werden. Die gleiche Nachricht erscheint in mehreren Internetportalen. Die Nachrichtenagenturen konzentrieren sich fast ausschließlich auf neutrale Nachrichten ohne emotionale Auswertung und auf päpstliche Pilgerreisen werden keine dedizierten Journalisten entsandt. Dies geschieht aus finanziellen Gründen und auch wegen keinem größeren Interesse für die Pilgerreisen, was die niedrige Anzahl der Nachrichten zeigt. Negative Informationen werden gleichmäßig in verschiedenen Portalen veröffentlicht, man kann somit nicht feststellen, dass die päpstliche Lehre und die Person des Papstes in einem der Portale in höherem Maße infrage gestellt wird. Die am meisten in der Medienübertragung vorkommenden Agenturmitteilungen informieren über die gegebenen Ereignisse, sie kommentieren sie allerdings selten. Unter den Publikationen beziehen sich die meisten auf Organisationsangelegenheiten oder auf Sachen, die nicht direkt mit dem Inhalt der päpstlichen Lehre zusammenhängen sowie, wie es im Forschungsjahr 2018 bemerkbar ist, auf die Sachen im Zusammenhang mit den sexuellen Missbräuchen von Minderjährigen und Unselbständigen durch Geistlichen, was in vielen Fällen fast vollständig die Narration betreffend die päpstliche Pilgerreise erfüllte.

Die erste apostolische Reise von Papst Franziskus im Jahre 2018 erfolgte nach Chile und Peru (vom 15. bis zum 21. Januar 2018). In Chile wurden heilige Messen in Santiago, Temuco und Iquique mit Teilnahme von ein paar hundert Tausend Gläubiger gehalten. Der Papst traf sich mit den einheimischen Völkern, Immigranten, Gefängnisinsassinnen, der Geistlichkeit, den Bischöfen, der Jugend, dem Universitätskreis und den Opfern der Pädophilie - es waren die Hauptereignisse des apostolischen Besuchs unter dem Motto „Meinen Frieden gebe ich euch“. Es war die 22. Auslandsreise von Papst Bergoglio und sein sechster Aufenthalt auf dem südamerikanischen Kontinent. Heiliger Vater versuchte insbesondere die örtliche Kirche zu unterstützen, die hauptsächlich wegen zahlreiche Fälle von Pädophilie unter den Geistlichen in der Krise versunken ist. Bereits in seiner ersten Rede - an die chilenischen Behörden - drückte er Kummer und Scham angesichts der den Kindern durch Kirchendiener zugefügten Schäden ohne zu zögern aus. Franziskus sprach nicht nur über dieses Thema, er traf sich auch mit den Opfern der Missbräuche. In seiner Rede an die Bischöfe sagte er wiederum 
sein kategorisches „Nein“ für den Klerikalismus aus. Der Papst sprach auch die Sache der Diskriminierung und der Verfolgungen der einheimischen Völker, insbesondere Mapuche an, die ihrerseits immer öfter Gewalt verüben, darunter Anstecken von christlichen Tempeln. In Peru hielt er zwei hl. Messen in Trujillo und Lima, jede mit der Teilnahme von ca. eine Million Gläubiger, Treffen mit der Bevölkerung von Amazonien, Vertretern der Behörden, der Geistlichkeit, Klausurordensschwestern, der Jugend und den Bischöfen. Das Motto war: „Geeint in der Hoffnung“. Der Papst konzentrierte sich auf die tiefen Probleme von Amazonien. Während de Treffens mit den Völkern wies er besonders auf die Zerstörungen im Zusammenhang mit dem Raubabbau der Ressourcen, dem Menschenhandel, genötigte Arbeitskräfte, sexueller Ausnutzung von Frauen, der Ausgrenzung und der Diskriminierung hin. Heiliger Vater verurteile ausdrücklich den Kulturkolonialismus und wies auf die Notwendigkeit der interkulturellen Bildung hin. Während des Treffens mit den peruanischen Behörden rief der Papst auch mit starken Worten auf, die Personen und lokale Völker anzuhören, anzuerkennen, zu respektieren sowie die integrale Ökologie als Alternative für den sozialen $\mathrm{Ab}$ stieg und die Umweltzerstörung zu fördern und zur entwickeln. Er betonte, dass das einzige Rezept für das Phänomen der Korruption größere Transparenz zwischen den öffentlichen Behörden, dem Privatsektor und der Bürgergesellschaft sind. Aufgrund der Mediennachrichten, die zu dieser Zeit erschienen, dominierte die Übertragung der Pilgerreise das Problem der Pädophilie. Ein anderes Thema waren die getrauten Stewards des Flugzeugs, mit dem der Bischof von Rom reiste. Die dargestellten theologischen Inhalte waren mit der sozialen Kirchenlehre verbunden ${ }^{12}$.

${ }^{12}$ Siehe [ohne Autor], Papież prosi o wybaczenie za skandal pedofilii $w$ Kościele, 16 I 2018, in: http://www.wiadomosci.onet.pl/swiat/papiez-prosi-o-wybaczenie-za-skandalpedofilii-w-kosciele/lw7q84j, [Zugriff: 7. Februar 2020]; K. Błaszkiewicz, Papież przeprasza za księży-pedofilów. Przełomowe słowa, 17 I 2018, in: http://www.wiadomosci.wp.pl/ papiez-przeprasza-za-ksiezy-pedofilow-przelomowe-slowa-6210239147264129a, [Zugriff: 7. Februar 2020]; [ohne Autor], Atak na Franciszka podczas pielgrzymki w Chile. Ochrona nie uchroniła papieża przed uderzeniem, 17 I 2018, in: http://www.wiadomosci.gazeta.pl/ wiadomosci/7,114881,22910539,to-nie-jest-latwa-pielgrzymka-najpierw-podpalono-koscioly.html, [Zugriff: 7. Februar 2020]; [ohne Autor], Papież: nie ma chrześcijańskiej radości, gdy zamyka się drogę imigrantom, 18 I 2018, in: http://www.fakty.interia.pl/swiat/news-papiez-nie-ma-chrzescijanskiej-radosci-gdy-zamyka-sie-drzwi-,nId,2510300, [Zugriff: 7 Februar 2020]; [ohne Autor], Papież Franciszek udzielił ślubu na pokładzie samolotu, 18 I 2018, in: 
Das Gebet und das ökumenische Treffen im Ökumenischen Zentrum des Weltkirchenrats (WKR), der das Jubiläum von 70 Jahren feiert, Mittagessen im Ökumenischen Institut in Bossey und hl. Messe mit der Teilnahme von mehr als 40 Tsd. schweizerischer Katholiken bildeten die zehnstündige „ökumenische Pilgerreise" von Franziskus am 21. Juni nach Genf in der Schweiz. Sie verlief unter dem Motto „Gemeinsam gehen, beten und arbeiten“. Heiliger Vater wies darauf hin, dass die Kirche einen neuen Evangelisierungsschwung braucht. Während der hl. Messe betonte er wiederum die Bedeutung des Treffens und des gemeinsamen Gebets. Das Hauptthema in der Pressenarration war das Problem der Christeneinheit und des Ökumenismus ${ }^{13}$.

http://www.wiadomosci.onet.pl/swiat/papiez-franciszek-udzielil-slubu-na-pokladzie-samolotu/9mlxhty, [Zugriff: 7. Februar 2020]; [ohne Autor], Papież przeprosił za słowa o biskupie z Chile w zwiq̨zku z pedofiliq, 22 I 2018, in: http://www.wiadomosci.onet.pl/swiat/papiezprzeprosil-za-slowa-o-biskupie-z-chile-w-zwiazku-z-pedofilia/hpl4mxj, [Zugriff: 7. Februar 2020]; [ohne Autor], Papież Franciszek wzywa do walki z plaga zabójstw kobiet w Ameryce Południowej, 21 I 2018, in: http://www.wiadomosci.onet.pl/swiat/papiez-franciszek-wzywa-do-walki-z-plaga-zabojstw-kobiet-w-ameryce-poludniowej/beb7q66, [Zugriff: 7. Februar 2020]; B. Goluch, Papież Franciszek przeprasza za wypowiedź na temat pedofilii. "Użyłem złych słów", 22 I 2018, in: http://www.o2.pl/artykul/papiez-franciszek-przeprasza-za-wypowiedz-na-temat-pedofilii-uzylem-zlych-slow-6212158191376513a, [Zugriff: 7. Februar 2020]; K. Winogrodzki, Papież Franciszek wysyła delegata. Zbada sprawę pedofilii, 30 I 2018, in: http://www.wiadomosci.wp.pl/papiez-franciszek-wysyla-delegata-zbada-sprawe-pedofilii-6214996304033409a, [Zugriff: 7. Februar 2020]; M. Kolewska, Papież Franciszek przeprasza. "Odczuwam ból i wstyd", 12 IV 2018, in: http://www.wiadomosci.wp.pl/papiez-franciszekprzeprasza-odczuwam-bol-i-wstyd-6240279096924289a, [Zugriff: 7. Februar 2020].

${ }^{13}$ Siehe [ohne Autor], Papież Franciszek odwiedza Szwajcarię, 21 VI 2018, in: http:// www.fakty.interia.pl/swiat/,ild,2536808,iAId,297896, [Zugriff: 7. Februar 2020]; [ohne Autor], Papież Franciszek odwiedził Szwajcarię, 21 VI 2018, in: http://www.fakty.interia.pl/galerie/swiat/zdjecie,iId,2536804,iAId,297896, [Zugriff: 7. Februar 2020]; [ohne Autor], Papież Franciszek krytykuje podziały wśród chrześcijan, 21 VI 2018, in: http://www.wiadomosci. onet.pl/swiat/papiez-franciszek-krytykuje-podzialy-wsrod-chrzescijan/jh0d9f4, [Zugriff: 7. Februar 2020]; [ohne Autor], Papież: podziały wśród chrześcijan, zgorszeniem dla świata, 21 VI 2018, in: http://www.fakty.interia.pl/religia/news-papiez-podzialy-wsrod-chrzescijan-sa-zgorszeniem-dla-swiata,nId,2596932, [Zugriff: 7. Februar 2020]; [ohne Autor], Papież Franciszek: każdy kraj powinien przyjmować migrantów z rozwaga, 20 I 2018, in: http://www. wiadomosci.onet.pl/swiat/papiez-franciszek-kazdy-kraj-powinien-przyjmowac-migrantowz-rozwaga/dj4v3jc, [Zugriff: 7. Februar 2020]; [ohne Autor], Papież: należy przyjmować tylu migrantów, ilu można, 22 VI 2018, in: http://www.fakty.interia.pl/religia/news-papiez-nalezy-przyjmowac-tylu-migrantow-ilu-mozna,nId,2597139, [Zugriff: 7. Februar 2020]; [ohne Autor], Papież Franciszek odwiedził Szwajcarię, 27 VI 2018, in: http://www.fakty.interia.pl/ swiat/iId,2536807,iAId,297896, [Zugriff: 7. Februar 2020]. 
9. Weltfamilientreffen in Irland mit der Teilnahme von Franziskus fand unter dem Motto: „Das Evangelium der Familie, Freude für die Welt“ vom 25. bis zum 26. August statt. Es bestand aus einem Treffen mit Vertretern der Behörden, der Bürgergesellschaft und des diplomatischen Corps im Dubliner Schloss, mit den Ehen sowie Verlobten in der Prokathedrale der Unbefleckten Empfängnis der Hl. Jungfrau Maria, Teilnahme an der Familienfeier im Stadium Croke Park mit 80 Tsd. Menschen, Besuch im Marienheiligtum in Knock sowie hl. Messe mit der Teilnahme von ca. 130 Tsd. Gläubiger in Dublin. Während der hl. Messe in Dublin zum Schluss des Ereignisses ermutigte der Papst, das Evangelium der Familie als Freude für die Welt mit anderen zu teilen. Im Rahmen des Bußgebets bat er Gott um Vergebung für die Missbräuche der Macht, des Gewissens und sexuelle Missbräuche, zu den es in den kirchlichen Institutionen in Irland kam und fürs mangelnde Mitgefühl der kirchlichen Vorgesetzten für die Opfer. Die journalistische Narration wurde vom Problem der sexuellen Missbräuche von Minderjährigen in der Kirche, der Seelsorge von homosexuellen Personen, jedoch auch, obwohl im geringerem Maße, von den theologischen mit der Ehe verbundenen Inhalten dominiert ${ }^{14}$.

${ }^{14}$ Siehe [ohne Autor], Papież spotka się z ofiarami pedofilii podczas wizyty $w$ Irlandii, 21 VIII 2018, in: http://www.fakty.interia.pl/swiat/news-papiez-spotka-sie-z-ofiarami-pedofiliipodczas-wizyty-w-irla,nId,2621458, [Zugriff: 10. Februar 2020]; [ohne Autor], Papież Franciszek odwiedza wstrzq̨sanq kościelnymi skandalami Irlandię, 24 VIII 2018, in: http://www. wiadomosci.onet.pl/swiat/papiez-franciszek-odwiedza-wstrzasana-koscielnymi-skandalami-irlandie/8950yrm, [Zugriff: 10. Februar 2020]; [ohne Autor], Papież spotka się z ofiarami pedofilii podczas wizyty w Irlandii, 25 VIII 2018, in: http://www.wiadomosci.onet.pl/swiat/irlandia-papiez-franciszek-spotkal-sie-z-ofiarami-pedofilii/0zjz9gr, [Zugriff: 10. Februar 2020]; [ohne Autor], Papież: małżeństwo jest ryzykiem. Ryzykujcie, 25 VIII 2018, in: http://www. fakty.interia.pl/raporty/raport-nowy-papiez/aktualnosci/news-papiez-malzenstwo-jest-ryzykiem-ryzykujcie,nId,2623132, [Zugriff: 10. Februar 2020]; [ohne Autor], Irlandia: 300 tys. osób na papieskiej mszy w Dublinie, 26 VIII 2018, in: http://www.fakty.interia.pl/swiat/newsirlandia-300-tys-osob-na-papieskiej-mszy-w-dublinie,nId,2623313, [Zugriff: 10. Februar 2020]; N. Durman, „Błagam Boga”. Emocjonalna przemowa Franciszka do dziesiątków tysięcy wiernych. Rozległy się brawa, 27 V 2018, in: http://www.wiadomosci.wp.pl/blagam-bogaemocjonalna-przemowa-franciszka-do-dziesiatkow-tysiecy-wiernych-rozlegly-sie-brawa6288503027398273a, [Zugriff: 10. Februar 2020]; [ohne Autor], Papież do rodziców homoseksualistów: należy rozmawiać, nie potępiać, 28 VIII 2018, in: http://www.wiadomosci.onet.pl/ swiat/papiez-do-rodzicow-homoseksualistow-nalezy-rozmawiac-nie-potepiac/cst9yrt, [Zugriff: 10. Februar 2020]; [ohne Autor], Papież przybył do Irlandii. „Podzielam zgorszenie i oburzenie z powodu pedofilii", 28 VIII 2018, in: http://www.fakty.interia.pl/swiat/news-papiezprzybyl-do-irlandii-podzielam-zgorszenie-i-oburzenie-,nId,2623060, [Zugriff: 10. Februar 
Das Hauptmotiv des Besuchs von Franziskus in Litauen am 22. und 23. September war der Appell um „Hinausgehende Kirche“ gegenüber den heutigen Randzonen und um die Hoffnung. Die Pilgerreise verlief nach dem Motto: „Jesus Christus - unsere Hoffnung“. Dieses Land war die erste Etappe des päpstlichen Besuch in den baltischen Ländern. In Vilnius ermutigte Heiliger Vater die Jugend, an der „Revolution der Sensibilität" teilzunehmen. Er betete auch am Spitzen Tor und am Grab von hl. Kasimir - Patron Litauens. Während der hl. Messe am Sonntag in Kaunas rief die Minderheit zur Offenheit auf, die in Litauen leben. Die Aussagen zur Wahrnehmung und zum Zuhören von Ausgeschlossenen ist ein festes Element der Narration des Papstes. Papst Franziskus bat die Geistlichen, nicht „Beamten Gottes“ zu werden. In ehemaliger Folterkammer von KGB in Vilnius betete er für die Opfer des Totalitarismus. Die zweite Etappe des Besuchs war Lettland, wo der Papst am 24. September Riga und Aglona besuchte. In der Hauptstadt traf er sich mit den Behörden des Landes und anschließend fand ein ökumenisches Treffen mit Vertretern von 10 Kirchen in der lutherischen Kathedrale statt. Am Nachmittage begab sich Franziskus zum nationalen Marienheiligtum in Aglona. Er sprach dort über Lettland als einen Ort des Dialogs und des Treffens sowie friedlicher Koexistenz, der versucht in die Zukunft zu schauen. Die dritte Etappe der päpstlichen Reise (25. September) war Estland. Hier gab es Treffen: mit Vertretern der Behörden und der Bürgergesellschaft, ökumenisches mit der Jugend in lutherischer Kirche hl. Karl und auch mit Bedürftigen und Armen, den kirchliche karitative Organisationen in der Kathedrale Hl. Peter und Paul helfen. Franziskus hielt hl. Messe am Friedensplatz in Tallinn mit der Teilnahme von fast allen örtlichen Katholiken, deren Zahl knappe 6 Tsd. beträgt, und auch von Christen anderer Konfessionen. Das Holocaust, totalitäre Regimes und auch evangelische

2020]; [ohne Autor], Papież: podzielam zgorszenie i oburzenie z powodu pedofilii, 25 VIII 2018, in: http://www.wiadomosci.onet.pl/swiat/papiez-w-irlandii-podzielam-oburzenie-z-powodu-pedofilii/k3s86pw, [Zugriff: 10. Februar 2020]. [ohne Autor], Abp Viganò oskarża papieża o tuszowanie skandalu. Dlaczego Franciszek nie zamierza komentować jego tez?, 28 VIII 2018, in: http://www.wiadomosci.onet.pl/religia/opinie/abp-vigano-oskarza-papieza-o-tuszowanie-skandalu-dlaczego-franciszek-nie-zamierza/2hmcrzc, [Zugriff: 10. Februar 2020]; B. Goluch, Papież Franciszek: Kościół przeżywa trudny moment. Musimy go bronić, 27 X 2017, in: http://www.wiadomosci.wp.pl/papiez-franciszek-kosciol-przezywa-trudny-moment-musimy-go-bronic-6310577144174209a, [Zugriff 25 III 2018]. 
Marcin Wrzos, Apostolische Auslandsreisen von Papst Franziskus, darunter Missionsreisen...

Wiederholung des Aufrufs zum Dialog und zur Einheit dominierten die journalistische Narration ${ }^{15}$.

Bei den die päpstlichen Auslandspilgerreisen im Jahre 2018 betreffenden Publikationen geht es in den analysierten Internetportalen in fast 83\% um Mitteilungen von Nachrichtenagenturen. Es kommt vor, dass die Mitteilungen in verschiedenen Internetdiensten kopiert werden. Es sind somit weder umfangreiche noch vertiefte Kommentare hinsichtlich der päpstlichen Lehre. Sichtbar ist die Tendenz zu immer kürzeren Berichten aus den päpstlichen Pilgereisen in den inländischen Internetportalen. Die päpstlichen Pilgerreisen im Jahre 2017 waren insbesondere mit dem Ökumenismus, dem religionsübergreifenden Dialog, den Flüchtlingen, der Friedenseinführung oder Evangelisierung durch Arbeit zugunsten der ausgeschiedenen Menschen verbunden. Die in den Laienmedien veröffentlichten theologischen Inhalte waren somit mit der Ekklesiologie, der Theologie

${ }^{15}$ Siehe [ohne Autor], Litwa: Kilkadziesiąt tysięcy osób oczekiwanych na papieskiej mszy $w$ Kownie, 22 IX 2018, in: http://www.fakty.interia.pl/swiat/news-litwa-kilkadziesiat-tysiecy-osob-oczekiwanych-na-papieskiej-,nId,2634878, [Zugriff: 10. Februar 2020]; [ohne Autor], Papież Franciszek na Litwie, 22 IX 2018, in: http://www.fakty.interia.pl// swiat/iId,2581575,iAId,306971, [Zugriff: 10. Februar 2020]; [ohne Autor], Litwa: 100 tysięcy osób na papieskiej mszy w Kownie, 23 IX 2018, in: http://www.fakty.interia.pl/swiat/news-litwa-100-tysiecy-osob-na-papieskiej-mszy-w-kownie,nId,2634906, [Zugriff: 10. Februar 2020]; [ohne Autor], Papież Franciszek na Litwie. Modlił się w dawnych celach KGB, w których torturowano więźniów, 23 IX 2018, in: http://www.wiadomosci.gazeta.pl/wiadomosci/7,114881,23959838,papiez-franciszek-na-litwie-modlil-sie-w-dawnych-celach-kgb. html, [Zugriff: 10. Februar 2020]; [ohne Autor], Papież Franciszek: okupacja, udręka deportowanych, groza gett i Syberii, 23 IX 2018, in: http://www.wiadomosci.onet.pl/swiat/papiezfranciszek-o-historii-na-litwie/b8h81es, [Zugriff: 10. Februar 2020]; [ohne Autor], Papież oddał hołd ofiarom getta $w$ Wilnie, 23 IX 2018, in: http://www.fakty.interia.pl/raporty/raport-nowy-papiez/aktualnosci/news-papiez-franciszek-oddal-hold-ofiarom-getta-w-wilnie,nId,2634998 [Zugriff: 10. Februar 2020]; [ohne Autor], Papież na kolanach $w$ więziennej celi. Tam bito i torturowano więźniów, 24 IX 2018, in: http://www.fakt.pl/wydarzenia/swiat/papiez-franciszek-na-kolanach-w-wieziennej-celi-w-wilnie-na-litwie/8hqymbt [Zugriff: 10. Februar 2020]; [ohne Autor], Papież Franciszek: niesienie pomocy nie może być turystykq solidarnościowq, 24 IX 2018, in: http://www.wiadomosci.onet.pl/religia/aktualnosci/papiezfranciszek-niesienie-pomocy-nie-moze-byc-turystyka-solidarnosciowa/pv3jm3x, [Zugriff: 10. Februar 2020]; [ohne Autor], Papież w Estonii: Niektórzy grożąc broniq̨ i wojskiem, wydają się silniejsi, 25 IX 2018, in: http://www.fakty.interia.pl/swiat/news-papiez-w-estonii-niektorzygrozac-bronia-i-wojskiem-wydaja-s,nId,2636038, [Zugriff: 10. Februar 2020]; [ohne Autor], apież na mszy w Tallinie: nie zdobyliście wolności, by stać się niewolnikami konsumpcjonizmu, 25 IX 2018, in: http://www.wiadomosci.onet.pl/religia/aktualnosci/papiez-na-mszy-w-tallinie-nie-zdobyliscie-wolnosci-by-stac-sie-niewolnikami/hgtze7g, [Zugriff: 10. Februar 2020]. 
der Barmherzigkeit, der Moraltheologie, der Theologie der Geistigkeit, dem Dialog, dem Ökumenismus und dem religionsübergreifenden Dialog verbunden. Man konzentrierte sich darin auf der Darstellung der überzeugenden Kirche, die nach Papst Franziskus eine solche wird, wenn sie beginnt, mit Sorge um den Menschen, insbesondere um den ausgeschlossenen und ausgeschiedenen zu leben.

\section{PASTORALE SCHLUSSFOLGERUNGEN}

Die erste Papstbotschaft zum Welttag der Massenmedien wurde nach dem 2. Vatikanischen Konzil im Jahre 1967 vom Papst Paulus VI. veröffentlicht. Es betonte die Betrachtung der sozialen Kommunikationsmittel als eines wichtigen Kommunikationswerkzeugs ${ }^{16}$. Die mit neuen Medien, darunter mit den Portalen zusammenhängenden Inhalte wurden darin allerdings erst ab 1990 aufgenommen, als die päpstliche Definition des Internets zum ersten Mal veröffentlicht wurde: „computerisiertes Teilnahmesystem“17. Es war sowieso eine schnelle Reaktion aufs Erscheinen des Internets, das ein Hauptträger neuer Medien ist. Johannes Paul II sprach sie immer öfter in seinen Botschaften direkt an, was zu einer Regel ab 2009, d. h. ab den Pontifikaten von Benedikt XVI. und dann von Franziskus wurde. Mit der Zeit begannen zusammen mit der Entwicklung der Digital- und Medientechnik folgende Begriffe in den analysierten Botschaften zu erscheinen: „neue Medien“, „Globalisierung“, „Mobiltelefone“, „Cyberspace“, „SMS“, „Android“, „Fakenews“ oder „Deepfake“18. Die Päpste wiesen immer auf die Rolle dieser Medien in der Gestaltung der heutigen Zivilisation hin, sowohl auf die Chance, die dieser Raum gibt, als auch auf die Gefahren. Die Frage der Algorithmen, die unsere Interaktionen in den sozialen Medien steuern, wurde auch von Franziskus bemerkt und als Hindernis im Bauen eines stimmigen Bildes der Welt angesehen. Die besprochenen Päpste wiesen auf die Notwendigkeit der christlichen Formation sowohl der Sender als auch der Empfänger auf. Sie glaubten, sie sind zur Evangelisierung und einer gewissenhaften ekklesischen Information zu nutzen. Neue Medien sollen ein gegenwärtiger Areopag werden, ein Ort des Treffens, in

${ }^{16}$ Siehe Paul VI., Orędzie na 1. Światowy Dzień Środków Społecznego Przekazu „Środki społecznego przekazu ważnymi elementami cywilizacji", 24. Januar 1967.

${ }^{17}$ Siehe Johannes Paul II., ebenda.

${ }^{18}$ Vergl. M. Wrzos, Neue Missionsmedien in Polen vor dem Hintergrund der Papstbotschaften zum Welttag der Massenmedien, in: „Studia Misjologiczne” 1 (8) 2018, S. 165-198. 
der Dialogkultur, auch für Menschen unterschiedlicher Religionen und Kulturen. Sie sind eine Chance für die Vertiefung der Bindungen, jedoch auch eine Gefahr.

Die Anwesenheit der Gemeinschaft der Kirche und ihrer Institution im virtuellen Raum, insbesondere unter den säkularen Sendern, ist notwendig und sogar unerlässlich, um die Evangelisierung mithilfe aller verfügbaren Werkzeuge zu führen. Ihre sachkundige Handhabung kann nicht nur das religiöse Bewusstsein der Internetnutzer ändern, sondern auch die christliche Einstellung im realen Leben gestalten. Internet kann als vielschichtiger Raum sowohl ein Ort des Gedankenaustauschs, der Evangelisierung, als auch ein Werkzeug der Verkündung von Evangelium werden. J. Kloch erhebt eine Forderung, das Internet auch als Werkzeug der Evangelisierung zu nutzen. Er glaubt, die Kirche, ihre partikulären Gemeinschaften und Institutionen sollen dieses Werkzeug zur Verkündung der Frohen Botschaft (Evangelisierung, Katechesen, Information), zum Heiligen (Bibel,

\section{Obwohl die Reichweite der christlichen Internetportale nicht groß ist, wird die Kirchenlehre darin dargestellt. In den Laienportalen sind jedoch die Kirche und die Kirchenlehre in begrenztem Umfang anwesend.}

Gebet, Exerzitien, Informationen über Pilgerreisen), zum Verbreiten der Wohltätigkeit (Sozialhilfe, Freiwilligendienst, Zusammenarbeit, Bilden der Gemeinschaft um die Initiative) und zum Lehren (theologische Reflexion, Bildung der ekklesischen Gemeinschaft) ${ }^{19}$.

Obwohl die Reichweite der christlichen Internetportale nicht groß ist, wird die Kirchenlehre darin dargestellt. In den Laienportalen sind jedoch die Kirche und die Kirchenlehre in begrenztem Umfang anwesend. Die Anzahl der veröffentlichten Mitteilungen betreffend die päpstlichen Pilgerreisen sinkt. Die meisten Nachrichten in den analysierten Portalen (www.onet.pl; www.wp.pl; www.interia.pl; www.gazeta.pl; www.o2.pl; www.fakt.pl) wurden während der jeweiligen

${ }^{19}$ Siehe J. Kloch, Kościół w Polsce wobec Web 2.0, Kielce 2013, S. 209-278. 
päpstlichen Pilgerreise und die übrigen bis 10 Tage davor und maximal 3 Tage danach, obwohl in einigen Fällen es der letzte Tag der Pilgerreise war, veröffentlicht (der Zeitunterschied bewirkte, dass die Nachrichten offiziell am nächsten Tag veröffentlicht wurden). Die die jeweilige Pilgerreise betreffenden Informationen „lebten“ somit ein paar Tage in den am meisten meinungsbildenden Portalen. Es gab sie im Durchschnitt zirka 40 je apostolischer Besuch $(43,25)$ in den sechs analysierten Portalen. Darunter gab es auch solche, z. B. betreffend die Schweiz oder die baltischen Länder, wo die Benachrichtigung über die päpstliche Pilgerreise sehr gering war bzw. mit der Beendigung der Pilgerreise zusammenfiel. Es wurde noch kein Werkzeug bearbeitet, das prüfen lässt, wie lange die jeweilige Nachricht auf der Hauptseite bleibt. Möglicherweise waren es ephemere Nachrichten. Am meisten wurden kopierte Agenturnachrichten ohne Kommentar veröffentlicht. Eine Ausnahme waren hier die Portale, die mit den katholischen Redaktionen eng zusammenarbeiten. Die engste Zusammenarbeit nahm der Portal www.onet. pl mit "Tygodnik Powszechny“ auf. Das Portal www.interia.pl nutze sporadisch die Texte von „Przewodnik Katolicki“. In diesen zwei Portalen kann man die meisten theologische, obwohl einzelne Besprechungen und breitere Übermittlung der päpstlichen Lehre sehen. Es scheint, es sei der richtige Weg, damit so viele wie möglich mit dem Leben der Kirche verbundenen Informationen in den Internetmedien veröffentlicht werden und damit sie zuverlässig dargestellt werden. Um zur Veröffentlichung solcher Inhalte in diesen Portalen zu führen, müssen sie den Redaktionen zur Verfügung gestellt werden. Eine gute Lösung wäre es auch, dass die Redaktionen eine enge Zusammenarbeit mit bestimmtem katholischen Medium bzw. einem Theologen - Journalisten gewährleistet hätten.

Es wäre nötig, dass die zentralen Kircheninstitutionen wie Nachrichtenbüro der Polnischen Bischofskonferenz oder der Pressesprecher der Apostolischen Nuntiatur eine Gruppe Menschen bilden würden, die sich mehr um die Anwesenheit der Kirche in den Medien durch Erstellung von die päpstlichen Pilgerreisen vorbereitenden bzw. zusammenfassenden Texten kümmern möchten. Auf ihren Seiten werden derartige Besprechungen üblicherweise nicht veröffentlicht. Wichtig, dass die Texte kommunikativ für den Empfänger sind und dass sie gemäß den Regeln des Internetjournalismus vorbereitet werden. Es können Laienfreiwilligen tun, den es lohnt sich, zu vertrauen und diesen Teil der Funktion der Kirch als den zu überlassen, die besser mit diesem Kommunikationswerkzeug umgehen können. Die Redaktionen, die fertige manchmal über interessante Elemente der 
Pilgerreise Mitteilungen oder Besprechungen erhalten, werden ein Werkzeug haben sie zu nutzen. Ein Teil davon nutzt keine Informationen von KAI aufgrund der Gebührenpflicht.

Gemäß der Forderung von J. Kloch ist eine breitere Anwesenheit der Kirche in den Internet- und Laienmedien möglich. Durch die Zusammenarbeit mit Internetmedien, die sich dafür interessieren, ist ihre noch breitere Nutzung möglich, insbesondere zur Evangelisierung, zu Katechesen, zur Information, zur Verkündung der ekklesischen Lehre zum jeweiligen Thema oder zum Bilden einer Gemeinschaft der Menschen, die sich an einer Initiative beteiligen möchten. Eine Voraussetzung scheint die Zusammenarbeit der Kirche mit diesen Medien und das Wirken der Menschen, die neue Medien nutzen können, zu sein. Eine deutliche engere Zusammenarbeit der Kirche mit den säkularen Medien ist somit notwendig. Ihre große Reichweite und Wirkungsbereich sollte dafür verwendet werden,

\section{Eine deutlich engere Zusammenarbeit der Kirche mit den säkularen Medien ist notwendig. Ihre große Reichweite und Wirkungsbereich sollte dafür verwendet werden, über Ereignisse aus dem Kirchenleben besser und mehr zu informieren.}

über Ereignisse aus dem Kirchenleben besser und mehr zu informieren. Die Pilgerreisen des Papstes, seine Lehre, Missionen, Engagement für ausgeschiedene Personen, Tätigkeit der Jugend sind Themen, die ein positives Image der Kirche in neuen Medien bilden sollten.

Es scheint eine Änderung der journalistischen Narration auf die nicht direkt mit dem theologisch- seelsorgerischen Thema der päpstlichen Besuche verbundenen Fragen bemerkbar zu sein, was aufgrund der Natur dieses Kommunikationswerkzeugs nicht wundert. Die Redakteure weisen auf die sexuellen Missbräuche von Minderjährigen, die Seelsorge von homosexuellen Personen oder unerwartete Ereignisse während der Besuche wie zufälliger Schlag des Papstes, Sturz der Polizisten aus dem Pferd und die ihr erteilte Hilfe vom Bischof von Rom hin. Papst Franziskus gewinnt auch durch bildliche Sprache und den Seelsorgestil wie z. B. 
Trauung der Stewards im Flugzeug die Aufmerksamkeit der sozialen Kommunikationsmittel. Es ist wünschenswert, dass derartige Narration die Grundlage für weitere vertiefte Evangelisierugs- und theologische Überlieferung wird, was in der medialen Strategie der Kirche zu berücksichtigen wäre.

Die Entwicklung der Technik bewirkt, dass die menschlichen Gewohnheiten sich schnell ändern. Mit dem Auftreten von Neuheiten gehen unsere Gewohnheiten auf ganz anderes Gleis. Dies gilt auch für den Zugang zur Information. Zuerst erschienen unter den sozialen Kommunikationsmitteln Zeitschriften, Radio, Fernsehen und heute ist das Internet sowie Medien, die die Technologie der Gedankenübertragung nutzen, das am meisten verbreitete Medium, das von rund $80 \%$ der polnischen Gesellschaft genutzt wird. Junge Leute lesen sporadisch Zeitschriften, hören Radio, am häufigsten sind sie stets „online“ anhand der Computer und der Mobilgeräte (Telefone, Tablets, Uhren, Handschuhe usw.). Neben den Internetmedien wie Webseiten und Internetportalen, sozialen Medien (Facebook, Twitter, Google+, Instagram oder Pinterest) spielen derzeit die größte Rolle die beliebtesten publizistischen Portale. Manche von ihnen erreichen mehr als 12,2 Mio. Leser monatlich, die das Portal auch ein paar Mal täglich lesen (www.wp.pl). In ihren Ressourcen, wie es scheint, sollen sich mit der Kirche, darunter auch mit den päpstlichen Pilgerreisen zusammenhängende Informationen befinden.

Aus den durchgeführten Forschungen geht es hervor, dass die päpstlichen Pilgerreisen kleines Interesse der analysierten Portale genossen. Über die vier päpstlichen Pilgerreisen (15.-21. Januar - Chile, Peru; 21. Juni - die Schweiz; 25.-26. August - Irland; 22.-25. September - Litauen, Lettland, Estland) wurden auf allen Portalen insgesamt 174 Informationen. somit 43,25 im Durchschnitt veröffentlicht. Am häufigsten waren es nach folgenden Agenturen veröffentlichte Nachrichten: der Katholischen Informationsagentur (KAI), der Polnischen Nachrichtenagentur (PAP), der Rundfunkinformationsagentur (RAI) und Radio Vatikan (RV). Ihre Anzahl beträgt 148 von 174, was 85,1\% der gesamten oft in verschiedenen Diensten duplizierten Informationen darstellt. Unter ihnen treten auch Bilder auf. Die Zeit der Veröffentlichung entsprach meistens der Zeit der apostolischen Reise selbst. Manchmal wurde sie durch Ankündigungen bzw. Zusammenfassungen eingeleitet, am häufigsten wurden sie jedoch nicht früher als 7 Tage veröffentlicht. Die sogenannte Lebensdauer einer päpstlichen Pilgerreise im Portal betrug durchschnittlich 7 Tage (so lange erschienen die Nachrichten zu diesem Thema, obwohl sie auf der Hauptseite nur für 2-3 Stunden anwesend 
waren) unter der Voraussetzung, dass die Pilgerreise überhaupt von der Redaktion des jeweiligen Portals bemerkt wurde. Der Anteil an negativen, positiven und neutralen Nachrichten war vergleichbar und unter den Portalen ist keines bemerkbar, das sich durch in Frage stellen der ekklesischen Tätigkeit auszeichnen würde. In der Regel konzentrierte man sich nicht auf die Inhalte der päpstlichen Botschaft, sondern auf die sexuellen Missbräuche von Minderjährigen, die Seelsorge von homosexuellen Personen oder unerwartete Ereignisse während der Besuche wie zufälliger Schlag des Papstes, Sturz der Polizisten aus dem Pferd und die ihr erteilte Hilfe vom Bischof von Rom.

Es scheint, dass die Zusammenarbeit mit den Internetmedien enger sein sollte. Es wäre vor allem für die Rezipienten von Vorteil, die ein breiteres Bild dessen erhalten könnten, wie die kirchliche Realität wirkt. Die zentralen Institutionen der Kirche hätten bei der Vorbereitung der Informationen über die Tätigkeit der Kirche, und früher bei Erarbeitung der medialen Strategie, bei der Zusammenarbeit mit den Laienredaktionen die Chance, ein positives Image zu kreieren sowie mehr Informationen oder theologischen Kommentaren zu veröffentlichen. Es ist wichtig, dass die Theologen, darunter Geistlichen, vorbereitet sind, sich der zu einem solchen Journalismus notwendigen Werkzeuge zu bedienen. Die Pilgerreisen des Papstes, insbesondere die Missionsreisen, seine Lehre, Missionen, Engagement für ausgeschiedene Personen, Tätigkeit der Jugend sind Themen, die ein positives Image der Kirche in den Internetmedien bilden sollten.

Als Zusammenfassung und Antwort auf die Forschungshypothesen scheint es, dass die erste: „Die Medien in Polen informieren sachgemäß über die Auslandspilgerreisen von Papst Franziskus (quantitativ und qualitativ)“ sei unbestätigt. Die zweite: „Die Vorbereitung der Geistlichen zur Benutzung neuer Medien und zur Benachrichtigung über die mit der Kirche verbundenen Fragen ist sachgemäß“ ist unbestätigt; und die dritte: „Die Anzahl der Informationen und die Benachrichtigungsart über die Auslandspilgerreisen ist ungenügend“ sei bestätigt.

\section{BIBLIOGRAFIE}

\section{A. Analysierte Dienste.}

Http://www.fakt.pl, [Jahr 2018].

Http://www.gazeta.pl, [Jahr 2018].

Http://www.interia.pl, [Jahr 2018]. 
Http://www.o2.pl, [Jahr 2018].

Http://www.onet.pl, [Jahr 2018].

Http://www.wp.pl, [Jahr 2018].

\section{B. Sonstige Publikationen}

Benedikt XVI., Orędzie na 43. Światowy Dzień Środków Społecznego Przekazu. Nowe technologie, nowe relacje. Trzeba rozpowszechniać kulturę szacunku, dialogu i przyjaźni, 24. Januar 2009.

E. Chudziński [Red.], Słownik wiedzy o mediach, Warszawa - Bielsko-Biała 2007

Franziskus, Orędzie na 50. Światowy Dzień Środków Społecznego Przekazu Komunikacja i Miłosierdzie - owocne spotkanie, 24. Januar 2016.

Franziskus, Orędzie na 52. Światowy Dzień Środków Społecznego Przekazu «Prawda was wyzwoli» (J 8, 32). Fake news a dziennikarstwo pokoju“, 24. Januar 2018.

Franziskus, Orędzie na 54. Światowy Dzień Środków Społecznego Przekazu "Abyś opowiadał dzieciom Twoim i wnukom» (Wj 10, 2). Życie tworzy historię", 24. Januar 2020.

Goban-Klas T., Media i komunikowanie masowe. Teorie i analizy prasy, radia, telewizji i Internetu, Warszawa 1999.

Hofman I., Paradygmaty nowej dyscypliny, in: „Studia Medioznawcze” 2019, (79) 4, S. 308-317.

J. Kloch, Kościół w Polsce wobec Web 2.0, Kielce 2013, S. 209-278.

Johannes Paul II., Orędzie na 24. Światowy Dzień Środków Społecznego Przekazu, Misja Kościoła w erze komputerów, 24. Januar 1990.

Kloch J., Kościół w Polsce wobec Web 2.0, Kielce 2013.

Krzysztofek K., Status mediów cyfrowych: stare i nowe paradygmaty, in: „Global Media Journal - Polish Edition" 2006, (1) 1, S. 14.

Levinson P., Nowe nowe media, Kraków 2010.

Manovich L., Język nowych mediów, Warszawa 2006.

Manovich L., New Media From Borges to HTML, Massachusetts 2003.

Nieć M., Komunikowanie społeczne i media, Warszawa 2010.

Paul VI., Orędzie na 1. Światowy Dzień Środków Społecznego Przekazu „Środki społecznego przekazu ważnymi elementami cywilizacji”, 24. Januar 1967.

Roman K., Najnowsze nowe media i stare nowe media. Spór o definicję nowych mediów, in: „Dyskurs” 2016, (22) 2, S. 20-39.

Szpunar M., Czym sq nowe media - próba konceptualizacji, in: „Studia medioznawcze” 2008, (35) 4, S. 32.

Szpunar M., Imperializm kulturowy Internetu, Kraków 2017, S. 3-134.

Szpunar M., W stronę nowych mediów, Toruń 2010.

Wrzos M., Neue Missionsmedien in Polen vor dem Hintergrund der Papstbotschaften zum Welttag der Massenmedien, in: „Studia Misjologiczne” 1 (8) 2018, S. 165-198. 


\section{Biogramm}

Marcin Wrzos OMI (geb. 1977), Priester, Missionar Oblate der Makellosen Jungfrau Maria; Doktor der Theologie im Fachgebiet Missionswissenschaft und Theologie der sozialen Kommunikationsmittel UKSW (2013), er absolvierte das Studium in politischen Wissenschaften und Journalismus UAM (2008), Polonistik UJ (2016) sowie Schutz personenbezogenen Daten UKSW (2018). Autor von Artikeln über Missionen in den sozialen Kommunikationsmitteln sowie über Nutzung der sozialen Kommunikationsmittel in Missionen. Er forscht die Anwesenheit der Kirche im Internet. Autor von vier Buchpublikationen: „Polskie czasopisma misyjne po II wojnie światowej. Studium misjologicznoprasoznawcze“ „Bibliografia polskich czasopism misyjnych. Lata 1945-2013“, „Oblates missionary press in Europe“ (Redakteur) und "Główne idee teologiczne, historia i funkcje oblackiego czasopiśmiennictwa misyjnego w Polsce (1926-2016)“ sowie von mehr als zehn wissenschaftlichen Artikeln. Ei ist freier Mitarbeiter der Fakultäten für Theologie der Universitäten UAM und USz. Er leitet die Veröffentlichung von „Misyjne Drogi“ und das Internetportal misyjne.pl.

ORCID: 0000-0003-3513-0158 


\title{
Robert Nęcek
}

Uniwersytet Papieski Jana Pawła II w Krakowie

\section{Prymas Stefan Wyszyński jako mistrz komunikacji. Analiza skonfiskowanego wywiadu prasowego „Katolicyzm w obliczu zagadnień współczesności” udzielonego red. Jerzemu Turowiczowi z zamiarem publikacji w „Tygodniku Powszechnym”}

\author{
The Primate Stefan Wyszyński as a Master of communication. \\ Analysis of confiscated press interview „Catholicism in the prism \\ of present-day issues" given to the editor Jerzy Turowicz \\ with intention to publicate it in „, Tygodnik Powszechny"
}

\begin{abstract}
ABSTRAKT
Prymas Stefan Wyszyński był mistrzem komunikacji. Jako redaktor pism i dziennikarz znał wartość słowa i międzyludzkiej komunikacji. Posiadał wyjątkowe kompetencje komunikacyjne i językowe. W swoich wystąpieniach, wywiadach

i rozmowach był profesjonalistą. Mając zamiłowanie do języka polskiego potrafił wysławiać się piękną polszczyzną, cytując polskich pisarzy i poetów dla poparcia swoich tez, co dodawało jego słowu jeszcze większej siły

i uznania. Kiedy po wojnie został mianowany

Prymasem Polski umiejętności dziennikarskie wykorzystywał w przepowiadaniu nauki Kościoła, a gdy zaszła taka konieczność udzielał wywiadów dla prasy kościelnej. Skonfiskowana rozmowa z Jerzym Turowiczem dla „Tygodnika

Powszechnego" była potraktowana jako niebezpieczna z punktu widzenia ideologicznego i komunikacyjnego. Kardynał przypomniał w niej Kościołowi podstawowe społeczne reguły, które nie były na rękę rządzącym.
\end{abstract}

SŁOWA KLUCZOWE:

dziennikarz, kompetencje komunikacyjne, kompetencje językowe, praca publicystyczna, przekaz profesjonalny, prasa, prawda, rozmowa

\begin{abstract}
The Primate Stefan Wyszyński was a Master of communication. As an editor of journals and as a journalist was knew perfectly the worth and value of a word and interpersonal communication. He owned communicational and lingual competences in the exceptional way. In his performances, interviews and conversations he was a professional. Having a love to Polish language he had an ability to talk with the beautiful Polish language, quoting the most respected polish writers and poets for supporting his thesis, what also gave more power and approval to his words. After a War when he was designated to be the Primate of Poland he was using journalist's abilities in giving Church's Teaching, and if it was necessary in giving interview to catholic press. Confiscated conversation with Jerzy Turowicz for „Tygodnik Powszechny” was from the ideological and communicational point of view dangerous. It reminded the fundamental truths to present Church, but also to Nation, which weren't suitable for governing.
\end{abstract}

\section{KEY WORDS:}

journalist, communicational competences, lingual competences, publishing work, professional message, press, truth, conversation 


\section{WSTĘP}

Prymas Stefan Wyszyński znał moc i siłę środków społecznego przekazu. Jego praca publicystyczna i redaktorska przypadła na okres trudny i wymagający, okres tworzącej się młodej demokracji międzywojennej. Będąc wytrawnym dziennikarzem wiedział, czym jest umiejętność komunikacji i znał wagę słowa przepełnionego obrazem, przenośnią i porównaniem. Dzięki pracy medialnej potrafił operować zrozumiałym i klarownym przekazem, a będąc jednocześnie człowiekiem rozległej i ugruntowanej wiedzy nie bał się zabierać głosu w ważnych sprawach dla Kościoła i społeczeństwa ${ }^{1}$.

Kiedy po wojnie został mianowany Prymasem Polski umiejętności dziennikarskie wykorzystywał w przepowiadaniu nauki Kościoła, a gdy zaszła taka konieczność udzielał wywiadów dla prasy kościelnej. W tym kontekście godnym uwagi jest zapomniana, ale mistrzowska rozmowa $\mathrm{z}$ redaktorem Jerzym Turowiczem z marca 1953 roku dla „Tygodnika Powszechnego”, która nie była opublikowana, gdyż została przez władze komunistyczne skonfiskowana. W kontekście komunikacyjnych zdolności kardynała Wyszyńskiego zostaną omówione podstawy systemowe przekazu, prostota przekazu elementem komunikacji zrozumiałej i zasadnicze wyznaczniki duszpasterskie dla Kościoła w świetle rozmowy z redaktorem Turowiczem.

\section{PODSTAWY SYSTEMOWE PRZEKAZU PRYMASA WYSZYŃSKIEGO}

Prymasowska komunikacja stanowiła wypracowany system przekazu i przyjmowała dwa aspekty: treściowy i relacyjny. W pierwszym aspekcie Kardynał przekazywał fakty, a w drugim wyjaśniał jak je należy przyjąć. Tym sposobem komunikacja wpływała na relacje społeczne, co przykładowo w mowie znajduje regulację w interpunkcji. Obydwa aspekty składają się na powstanie przekazu². Czym zatem jest przekaz? Potocznie przekaz rozumiany jest jako transmisja wiedzy i umiejętności. Przekazywać coś komuś oznacza tyle, co uczyć kogoś czegoś, zwracać mu na coś uwagę. W takim pojęciu przekazu skonkretyzowane zostają powiązania z działaniem i symbolami, a wiedza i umiejętności są zauważalne,

${ }^{1}$ Por. M. Laskowska, Postulaty etyczne dla mediów w publicystyce ks. Stefana Wyszyńskiego, „Kultura-Media-Teologia” nr 3 (2010), s. 93-95.

${ }^{2}$ Por. F. W. Kron, A. Sofos, Dydaktyka mediów, Gdańsk 2008, s. 51-52. 
gdyż sam przekaz zmusza do refleksji i zastanowienia się nad nim ${ }^{3}$. W takiej perspektywie przybliżone zostaną: ogólna charakterystyka kompetencji, kompetencje komunikacyjne i językowe w prymasowskim przekazie.

\section{Kompetencja - ogólna charakterystyka}

Generalnie znaczna część kompetencji wypływa z doświadczenia życia. Zwrócił na to uwagę kardynał Wyszyński kiedy podkreślił, że praca osiąga swój cel gdy jest wykonywana zgodnie $\mathrm{z}$ wyznaczonym sobie założeniem, które musi być w dobrze przez człowieka uświadomione. W przeciwnym razie, gdy praca jest realizowana źle i niefachowo prowadzi do destrukcji, braku zaufania i rozłamu ${ }^{4}$. $\mathrm{Z}$ tej racji kompetencja charakteryzuje się trzema wyznacznikami:

- Zdolnością do zrobienia czegoś

- Fachowym przygotowaniem osoby do rozwiązania problemu

- Zdolnością do komunikacji międzyludzkiej5.

Oczywiście, sama kompetencja nie wystarczy. Chodzi bowiem o zespolenie jej z uczciwością, gdyż w ten sposób pojawia się pozytywny efekt ładu społecznego. Tymczasem „coraz więcej dobrych zawodowców, coraz mniej uczciwych ludzi! Dlatego życie wśród nich staje się coraz trudniejsze" ${ }^{\prime \prime}$. Dlatego nie ma dobrobytu bez kompetentnej i uczciwej komunikacji.

\section{Kompetencje komunikacyjne}

W podstawach systemowych przekazu prymas Wyszyński nabywał określonych umiejętności nazywanych kompetencjami komunikacyjnymi. Chodzi więc o zdolność komunikatywnego kontaktu z wiernymi. Miał świadomość tego, że sama aparatura techniczna nie wystarczy do wzajemnego zrozumienia ${ }^{7}$. Co więcej, konieczne jest doświadczenie, będące owocem pracy wielu lat. Toteż komentując „Porozumienie” z rządem pisał 27 września 1953 roku, że „seminaria otrzymały młodych profesorów, wydziały teologiczne zdołały zaledwie skompletować siły

${ }^{3}$ Por. Tamże, s. 52.

${ }^{4}$ Por. R. Nęcek, Państwo w nauczaniu społecznym Prymasa Polski Stefana Wyszyńskiego, Kraków 2004, s. 190.

${ }^{5}$ Por. F. W. Kron, A. Sofos, Dydaktyka mediów, Gdańsk 2008, s. 53.

${ }^{6}$ S. Wyszyński, Ratujmy nasze człowieczeństwo i życie narodu. Do lekarzy (Warszawa, 23.03.1969), w: Nauczanie społeczne 1946-1981, Warszawa 1991, s. 384.

${ }^{7}$ Por. R. Nęcek, Citizens obligations towards the state in the context of the homiletics of the Primate of Poland Stefan Wyszyński, „Studia Theologica Varsaviensia” nr 2 (2018), s. 84-85. 
naukowe, redakcje pism katolickich zdołały wyszkolić personel fachowy, wydawnictwa katolickie zdołały zaledwie stworzyć aparat techniczny. Zaledwie odbudowano i odnowiono świątynie, rozpoczęto tworzyć nowe parafie, wznosić gmachy szkół katolickich. Duchowieństwo, choć podniosło swój poziom w pracy w sposób widoczny, pracowało jeszcze starymi lub zapożyczonymi wzorami”. ${ }^{\text {. }}$

\section{Prymas Polski miał odpowiednie predyspozycje komunikacyjne.}

Słowa te świadczą o wyjątkowym profesjonalizmie Prymasa Polski. Oczywiście „profesjonalizm - jak podkreśli papież Franciszek - jest kształtowany, a częściowo również się go nabywa. Sądzę jednak, że do tego, aby się uformował i aby można było go nabyć, od poczq̨tku musza być dobre podstawy"9. Papieskie spostrzeżenie jest słuszne, gdyż prymas Polski miał odpowiednie predyspozycje komunikacyjne, które były mocno zakotwiczone w solidnej wiedzy i obyciu w świecie. Kardynał Stefan Wyszyński uczęszczał na wykłady z nauk społecznych w zakresie polityki społecznej, pisząc jednocześnie doktorat z prawa kanonicznego ${ }^{10}$. $\mathrm{Na}$ przełomie 1929/1930 odbył podróż naukową po zachodnioeuropejskich ośrodkach naukowych zajmujących się katolicką nauką społeczną. Był także - już jako neoprezbiter - redaktorem dziennika diecezjalnego „Słowo Kujawskie”, wydawanego przez kurię diecezjalną we Włocławku. Dodatkowo potrafił poszerzać swoje kompetencje komunikacyjne w świetle różnorodnych uwarunkowań życiowych, na które wpływ miały czynniki społeczne, kulturowe, nade wszystko z typowo ludzkie. Jednak źródło jego profesjonalizmu znajdowało się $\mathrm{w}$ rodzinie. $\mathrm{Z}$ domu rodzinnego bowiem „wniósł $w$ dorosłe życie umiłowanie Ojczyzny i Kościoła, z którymi się identyfikował"11 i umiał to przełożyć na rzeczywistość zrozumiałą.

\footnotetext{
${ }^{8}$ S. Wyszyński, O „Porozumieniu (Rywałd koło Lidzbarka, 27.09.1953), w: S. Wyszyński, Dzieła zebrane 1949-1953, t. I, Warszawa 1991, s. 262.

${ }^{9}$ Franciszek, Służba Kościołowi powszechnemu i Kościołom partykularnym. Bożonarodzeniowe spotkanie z Kuriq Rzymska (21.12.2014), „L'Osservatore Romano” nr 2 (2014), s. 14-15.

${ }^{10}$ Por. M. Sitarz, Stefan Wyszyński - od dzieciństwa do absolwenta KUL, w: Stefan Wyszyński Prymas Tysiąclecia - absolwent KUL kandydat na ołtarze, red. M. Sitarz, A. Słowikowska, A. Romanko, Lublin 2017, s. 24-30.

${ }^{11}$ Marian Romaniuk cytuje słowa ks. dr Bronisława Piaseckiego z referatu Stefan kardynał Wyszyński - uwarunkowania osobowości. M. P. Romaniuk, Prymas Tysiąclecia w pamięci Polaków 1981-2011, Warszawa 2011, s. 330.
} 


\section{Kompetencje językowe}

Kardynał Wyszyński poza kompetencjami komunikacyjnymi posiadał także kompetencje językowe. Chodzi o to, że przekaz realizuje się nie tylko w słowie pisanym, ale szczególnie w słowie mówionym. Dlatego znajomość sztuki dziennikarskiej przekaz Prymasa jedynie ułatwiało. Kardynał sam o tym mówił: „od młodości byłem redaktorem najrozmaitszych pism. Tak mnie jakoś Pan Bóg urządził. Najpierw wydałem pismo kleryckie, później jako neoprezbiter musiałem być redaktorem dziennika diecezjalnego „Słowo Kujawskie”. Nie mając pojęcia o tym, co to jest dywizorek, metrampaż itp. Musiałem wszystkiego nauczyć się sam"12. Oczywiście warsztat przekazu to nie wszystko. Powodzenie prymasa - oprócz talentów i solidnego wykształcenia - wypływało z uświęconego wnętrza, które było wolne od osobistych uprzedzeń i animozji. Zresztą, prymas - co słusznie zauważył ks. Jerzy Jastrzębski - przypominał światu medialnemu to, co tkwiło w jego sercu i umyśle, mianowicie: przekazem można służyć społeczeństwu jedynie wtedy, kiedy jest się człowiekiem o określonych przymiotach ducha ${ }^{13}$.

Inaczej mówiąc: kardynał Wyszyński miał świetne społeczne podstawy naukowe, dobry warsztat dziennikarski i wysoki poziom moralny. Dzięki temu był dla wiernych przekonujący i mógł w swoim przekazie zwracać uwagę na różne problemy.

\section{PROSTOTA PRZEKAZU ELEMENTEM KOMUNIKACJI ZROZUMIALEJ}

Niewątpliwie istotą skutecznego przekazu będącego elementem komunikacji zrozumiałej była w wypowiedziach Kardynała prostota. Promować przekaz prosty to promować przekaz prawdziwy. Nieprzypadkowo więc podkreślił, że „wszyscy pragniemy prawdziwości, prawdomówności, wyzwolenia się ze słów, które nic nie mówiq albo, które budzą zastrzeżenia i wątpliwości"14.

${ }^{12}$ Instytut Prymasowski Stefana Kardynała Wyszyńskiego: Kardynał Stefan Wyszyński (3.081901-28.05.1981). Cyt. Za: M. Sitarz, Stefan Wyszyński - od dzieciństwa do absolwenta KUL, w: Stefan Wyszyński Prymas Tysiąclecia - absolwent KUL kandydat na ołtarze, red. M. Sitarz, A. Słowikowska, A. Romanko, Lublin 2017, s. 17.

${ }^{13}$ Por. J. Jastrzębski, Paragraf w sercu. Kardynał Stefan Wyszyński o miłości i sprawiedliwości społecznej, Kraków 2014, s. 295.

${ }^{14} \mathrm{~S}$. Wyszyński, Kościół $w$ wymiarze międzynarodowym. Do duchowieństwa stolicy (2.08.1975), w: Nauczanie społeczne 1946-1981, Warszawa 1991, s. 650. 
W tej perspektywie Prymas przestrzegał przed światem koniunkturalizmu posługującego się kłamstwem. Świat ten zawsze idzie w nieskończoność, gdyż kłamstwo jest wielorakie. Koniunkturalizm lubi politykować i łatwo jest go schwytać na sprzecznościach. Dlatego apelował szczególnie do młodzieży, by budziła w sobie impuls dociekliwego poszukiwania prawdy ${ }^{15}$, gdyż przekaz dobry może się opierać jedynie na komunikacji prawdy. Z tej racji tam gdzie brakuje prawdy, tam też brakuje szacunku dla ludzi, bo czyż można kochać bliźnich, okłamując ich? Dlatego przypomnienie o więzi wiary z prawdą w przekazie jest nad wyraz aktualne, gdyż „współczesny człowiek na ogół innym nie wierzy; ale sq jeszcze ludzie tacy ludzie, którym wierzy”16. Tymczasem „we współżyciu społecznym to olbrzymi rozdział! Jesteśmy przerażeni kłamstwem wielkich"17. W tym kontekście zostaną omówione dwa zagadnienia: rozmowa istotą komunikacji i umiejętność posługiwania się słowem literackim.

\section{Gdzie brakuje prawdy, tam brakuje szacunku dla ludzi.}

\section{Rozmowa istotą komunikacji}

Prymas Wyszyński jako mistrz komunikacji rozumiał, że rozmowa staje się jej istotą. Oznacza to, że przez dyskusje, mowę i inne środki przekazu można przyswajać sobie rzeczywistość i zmieniać ją w twórczy sposób. Niewątpliwie prymasowskie mistrzostwo w przekazie zauważyli dziennikarze niemieccy komentując sprawę pojednania polsko-niemieckiego w następujących słowach: „Zdrowy ludzki rozsq̨dek idzie $w$ parze $z$ sentymentalizmem, wielkoduszność $z$ wrażliwościq na drobiazgi. Ponad tym wszystkim widnieje iście »pańskie zachowanie się" [...]. Pod jednym względem przewyższa Wyszyński szefa partii [...] jest człowiekiem, którego

${ }^{15}$ Por. R. Nęcek, Państwo w nauczaniu społecznym Prymasa Polski Stefana Wyszyńskiego, Kraków 2004, s. 107-108.

${ }^{16}$ S. Wyszyński, Moc żywej wiary w ciężkiej sytuacji Kościoła. Do duchowieństwa (Gdańsk, 23.10.1960), w: Nauczanie społeczne 1946-1981, Warszawa 1991, s. 164.

${ }^{17}$ S. Wyszyński, Czekamy na człowieka! Podczas uroczystości błogosławionego Władysława z Gielniowa, patrona stolicy (25.09.1961), w: Nauczanie społeczne 1946-1981, Warszawa 1991, s. 1183-185. 
potęga tkwi w przemówieniu. Jego kazania stały się ostra broniq̨. Swoim jasnym, klasycznym, czysto polskim językiem przewyższa szefa partii” ${ }^{\prime 18}$.

Umiejętność operowania słowem i wyjątkową zdolność przekonywania zauważył już w początkowej fazie kapłaństwa biskup pomocniczy z Włocławka Franciszek Korszyński podkreślając na łamach „Ateneum Kapłańskiego” talent pisarski ks. Wyszyńskiego, gdy jako redaktor „Słowa Kujawskiego” umieszczał w tym dzienniku artykuły redakcyjne. Podziwiano wówczas świeżość i dojrzałość wyrażanych myśli, szlachetną prostotę i bogactwo słowa ${ }^{19}$.

\section{Umiejętność posługiwania się słowem literackim}

Prymas Stefan Wyszyński w swojej komunikacji posługiwał się językiem literackim i piękną polszczyzną. W swoich publicznych wystąpieniach podkreślał wartości duchowe i artystyczne, przywołując wielkich pisarzy i twórców kultury polskiej ${ }^{20}$. W sposób szczególny zamiłowany był w romantyzmie. Przywoływał Norwida, Wyspiańskiego i Sienkiewicza. Zachwycał się twórczością Makuszyńskiego i pięknem jego mowy ojczystej, a zwłaszcza tak mało znaną naszemu współczesnemu pokoleniu - Pieśniq o Ojczyźnie, a w niej - Odq̨ do mowy ojczystej. Był teologiem, socjologiem, prawnikiem i polonistą. Z łatwością cytował długie passusy z dzieł Jana Kasprowicza, Jana Lechonia, Zygmunta Krasińskiego, Juliana Tuwima, ale też ks. Jana Twardowskiego czy Konstantego I. Gałczyńskiego ${ }^{21}$.

${ }^{18}$ Piotr Łysakowski przywołuje ten cytat w „Komentarzach Historycznych IPN”. AIPN 0445/12, t. 1-2. Tłumaczenie z „Neue Zürcher Zeitung”, „Kardynał Wyszyński - Prymas Polski przeciwnik Gomułki", 25 I 1966 s.61-62. P. Łysakowski, Prymas Wyszyński - twórca polsko-niemieckiego dialogu i pojednania, „Komentarze Historyczne IPN”, (2018), s. 76.

${ }^{19}$ Por. F. Korszyński, Redaktor Ateneum Kapłańskiego - biskupem lubelskim, „Ateneum Kapłańskie” nr 45 (1946), s. 3-10; J. Bagrowicz, Ksiądz Stefan Wyszyński jako redaktor naczelny „Ateneum Kapłańskiego”: z okazji 70. Rocznicy święceń kapłańskich, „Łódzkie Studia Teologiczne" nr 3 (1994), s. 307.

${ }^{20}$ Por. K. Lewandowska, Kardynał Stefan Wyszyński - obrońca historii, tradycji i kultury polskiej, „Perspectiva. Legnickie Studia Teologiczno-Historyczne” nr 1 (2012), s. 66. (59-78).

${ }^{21}$ Por. Tamże, s. 68. Oto fragment wypowiedzi Prymasa: „Jest to wielka tajemnica Boża. Polacy sq dziwnym narodem. Właśnie wtedy, gdy im trudno, gdy majq wielkie przeciwności, zdobywaja się na potężne wysiłki. W czasie beznadziejnej niewoli pojawiły się najpiękniejsze postacie - wspaniała trójca wieszczów narodowych: Mickiewicz, Krasiński, Słowacki, później Norwid, wreszcie Sienkiewicz - potężne duchy, wyrosłe z bólu, męki i cierpienia Narodu. Jest coś w Narodzie polskim, że właśnie wtedy, gdy mu ciężko, mobilizuje wszystkie siły i zwycięża". S. Wyszyński, Z rozważań nad kultura ojczystą, Poznań-Warszawa 1979, s. 116. 
Kardynał Wyszyński mając tak wszechstronne wykształcenie potrafił w swojej komunikacji być wyjątkowo sugestywnym, nadającym ton i przekonywującym. Można stwierdzić, że w swoim przekazie zawierał cztery podstawowe i wyróżnione przez Noama Chomsky kompetencje:

- Kreatywność - ze skończonego zbioru elementów językowych tworzenie nowych spójnych wypowiedzi.

- Gramatyczność - poprawność znaczeniowa i znajomość leksyki i reguł łączenia wyrazów ze sobą.

- Akceptabilność - zdolność rodzimego użytkownika języka do uznawania wypowiedzi za poprawną, zgodną z obowiązującą normą.

- Interioryzacja - proces nieuświadamianego opanowywania ojczystego języka ${ }^{22}$.

\section{Osoba może z powodzeniem uczestniczyć w procesie komunikacyjnym wtedy, kiedy posiada pewnego rodzaju kompetencje i sprawności.}

Od poziomu integracji wymienionych kompetencji zależała efektywność komunikacji kardynała Wyszyńskiego. Chodzi o to, że osoba może z powodzeniem uczestniczyć w procesie komunikacyjnym wtedy, kiedy posiada pewnego rodzaju kompetencje i sprawności. One się wzajemnie przenikają. Wówczas kompetencje stające się wiedzą, „nie mogą się pojawić w umyśle ludzkim bez określonych sprawności. Pewne sprawności zaś, przynajmniej te, które przyjmuja postać realizacyjnych umiejętności, nie ujawniq się bez nabytej wcześniej kompetencji”23.

\section{WYZNACZNIKI DLA KOŚCIOŁA W ŚWIETLE ROZMOWY Z REDAKTOREM JERZYM TUROWICZEM}

Niewątpliwie kardynał Wyszyński jako mistrz komunikacji nie unikał rozmów medialnych. Wykorzystywał nadarzającą się okazję do wyłożenia podstawowych

${ }^{22}$ Wyszczególnione kompetencje podane za Małgorzatą Trusz. Por. M. Trusz, Kompetencja językowa a kompetencja komunikacyjna, w: https://szkolnictwo.pl/index.php?id=PU7110

${ }^{23}$ Tamże. 
zasad i kierunków działania Kościoła w Polsce. W tym przypadku podjął się rozmowy z redaktorem Jerzym Turowiczem, reprezentującym „Tygodnik Powszechny". Niestety całość wywiadu - z powodu cenzury - została w marcu 1953 roku w całości skreślona z publikacji. Dlatego w tym kontekście zostaną przedstawione - okoliczności konfiskaty tekstu rozmowy i wyzwania Kościoła wobec problemów współczesności.

\section{Okoliczności konfiskaty tekstu rozmowy}

Na wstępie należy zaznaczyć, że czas udzielenia wywiadu dla „Tygodnika Powszechnego" był okresem silnej tendencji cenzurowania treści publicznego dyskursu. Warto podkreślić, że w dniu 9 lutego 1953 roku został wydany rządowy dekret o obsadzie stanowisk kościelnych, a generalnie chodziło o polityczną presję na duchowieństwo, usuwanie religii ze szkół i bezwzględne niszczenie prasy i wydawnictw katolickich. Dla poparcia stanowiska rządowego Bolesław Piasecki w dniu 2 marca 1953 roku opublikował w „Słowie Powszechnym” artykuł Dwie drogi katolicyzmu, w którym przyznał, że postępowanie władz komunistycznych jest uzasadnione, bowiem Kościół katolicki w Polsce przez wiele lat wspierał burżuazję. Wyróżnił dwie drogi katolicyzmu:

- jedna reprezentowana przez Kościół, który popiera kapitalizm

- druga reprezentowana przez katolików świeckich budujących socjalizm i popierających władze komunistyczne ${ }^{24}$.

W takiej właśnie atmosferze społecznej Prymas zdecydował się na rozmowę z redaktorem Turowiczem. Dnia 17 marca 1953 roku „przybył Jerzy Turowicz, z którym omawiałem projekt wywiadu do „Tygodnika Powszechnego” zgodnie z liniq ostatecznej rozmowy mojej z marszałkiem Mazurem. Projekt ma być zarazem odpowiedziq na artykuł: Mazur - Piasecki - Brystygierowa $w<$ Słowie Powszechnym > Dwie drogi katolicyzmu. Moralna wymowa sytuacji międzynarodowej"25. Właśnie ta rozmowa miała być odpowiedzią za zaistniałą trudną sytuację $\mathrm{w} \mathrm{kraju}^{26}$.

${ }^{24}$ Por. M. Tunak, Pomiędzy partiq a Kościołem. Komu służyła grupa Piaseckiego? (17.11. 2017), w: https://historia.org.pl/2017/11/07/pomiedzy-partia-a-kosciolem-komu-sluzylagrupa-piaseckiego/

${ }^{25}$ S. Wyszyński, Katolicyzm w obliczu zagadnień współczesności. Rozmowa red. Turowicza z Księdzem Prymasem (Gniezno, marzec 1953), w: S. Wyszyński, Dzieła zebrane 1953-1956, t. II, Warszawa 1995, s. 269.

${ }^{26}$ Por. E. Czaczkowska, Kardynał Wyszyński. Autorytety, Warszawa 2009, s. 153. 
Jednak prymasowska rozmowa nie ukazała się, gdyż została w całości skonfiskowana. Na maszynopisie istnieje własnoręczna adnotacja Prymasa <skonfiskowane>. Dodatkowo kardynał Wyszyński dodał: „jestem zdania, że jest to odpowiedź pana Mazura, który oczekiwał uzgodnienia tekstu. Jestem zdania, że pan Mazur nie może być moim korepetytorem. Gotów jestem zrezygnować $z<$ Rozmowy>, ale uzgadniać jej nie mam zamiaru"27. Jednocześnie znajduje się dyspozycja odbicia 25 egzemplarzy i rozesłania do wszystkich diecezji i biskupów wymienionych przez niego ${ }^{28}$.

\section{Wyzwania Kościoła wobec problemów współczesności}

W skonfiskowanym wywiadzie dla „Tygodnika Powszechnego” Prymas przypomniał o podstawowej roli Kościoła. Jego rozmowa była przejrzysta i precyzyjna. Już pierwsze pytanie Jerzego Turowicza rozbija na szereg pytań oddzielnych i szczegółowych. Przypomina, że istotą Kościoła jest prowadzenie wiernych do spotkania z Chrystusem. Oznacza to, że jest społecznością nadprzyrodzoną. Nie jest więc żadnym systemem politycznym, ani gospodarczym. Jest społecznością religijną. Rola Kościoła przejawia się więc następującymi elementami:

- Kościół jest powszechną wspólnotą sumień. Poprzez ukształtowane sumienia można oddziaływać na sumienie rodziny, narodu, struktur zawodowych, gospodarczych, politycznych zawsze przekazując niezmienną prawdę teologiczną i moralną.

- Kościół przekracza wszelkie granice i wszelkie więzi doczesne i polityczne.

- Próby wiązania Kościoła z orientacjami i ugrupowaniami sił „wskazują na brak poczucia rzeczywistości i wyobraźni katolickiej, która nie dostrzega niewspółmierności zadań"29.

- Wszelkie bloki i ugrupowania polityczne nie mają żadnej analogii z Kościołem.

- Kościół nigdy nikomu nie zostawia w sporach politycznych mandatu do jego reprezentowania bądź obrońcę.

${ }^{27}$ S. Wyszyński, Katolicyzm w obliczu zagadnień współczesności. Rozmowa red. Turowicza z Księdzem Prymasem (Gniezno, marzec 1953), w: S. Wyszyński, Dzieła zebrane 1953-1956, t. II, Warszawa 1995, s. 269.

${ }^{28}$ Tamże, s. 269.

${ }^{29}$ Tamże, s. 265. 
- Kościół nie może „być ustawiony po jednej stronie, że Kościół nie może w nikim z ludzi upatrywać swego wroga. Wobec każdego człowieka Kościół jest posłannikiem Bożym, każdemu ma opowiadać Doba Nowinę, nie może więc do nikogo zamykać sobie drogi" 30 .

- Kościół ma spełniać swoje posłannictwo w warunkach, w jakich się znalazł.

- Kościół nie zajmuje się organizowaniem życia gospodarczego.

- Kościół nie wiąże swojej misji z żadnym z ustrojów ${ }^{31}$.

Kardynał Wyszyński zauważył także, iż katolicy nie zawsze i nie wszędzie stanęli na wysokości zadania. W historii dało się zauważyć wiele zaniedbań. Zbyt często „ulegano pokusie oportunistycznego zwiq̨zku z warstwami posiadającymi, zaniedbujq̨c sprawę walki z krzywdq społecznq. Stwierdzić też trzeba, że i obecnie $w$ wielu krajach, gdzie katolicy maja wpływ na rzady dzieło reform społecznych nie jest należycie realizowane" ${ }^{\prime 32}$.

Niezwykle godnym uwagi jest stwierdzenie Prymasa, że Kościołowi w każdych warunkach konieczna jest reforma polegająca na nawracaniu się do życia według Ewangelii. Środki takie jak, „jak posiadanie dóbr i wpływy materialne, moga być dla Kościoła pożyteczne, służyć dobrej sprawie, ale nie sq istotne, moga zaś stać się obciq̨żeniem. Istotna jest ta praca, której dokonuje Kościół, posługując się środkami sobie właściwymi: głoszeniem prawdy i rozdawnictwem łask"33.

Rozmowa kardynała Wyszyńskiego z redaktorem Jerzym Turowiczem była niezwykle żywą i pasjonującą rozmową. Wprowadza rozmówcę w rzeczywistość głębszego myślenia, które stawia kolejne pytania i wyzwala konieczność odpowiedzi na nie.

\section{ZAKOŃCZENIE}

Reasumując należy stwierdzić, że Prymas Stefan Wyszyński był mistrzem komunikacji. Jako redaktor pism i dziennikarz znał wartość słowa i międzyludzkiej komunikacji. W swoich wystąpieniach, wywiadach i rozmowach był profesjonalistą, który posiadał wyjątkowe kompetencje komunikacyjne i językowe. Mając zamiłowanie do języka polskiego potrafił wysławiać się piękną polszczyzną, cytując

\footnotetext{
30 Tamże, s. 266.

${ }^{31}$ Tamże, s. 267.

${ }^{32}$ Tamże.

${ }^{33}$ Tamże, s. 268.
} 
polskich pisarzy i poetów dla poparcia swoich tez, co dodawało jego słowu jeszcze większej siły i uznania. Nie dziwi więc, że skonfiskowana rozmowa z Jerzym Turowiczem dla „Tygodnika Powszechnego” była potraktowana jako niebezpieczna z punktu widzenia ideologicznego i komunikacyjnego. Przypominała bowiem podstawowe prawdy współczesnemu Kościołowi, ale i państwu które nie były na rękę rządzącym.

\section{BIBLIOGRAFIA}

Bagrowicz J., Ksiq̨dz Stefan Wyszyński jako redaktor naczelny „Ateneum Kapłańskiego”: z okazji 70. Rocznicy święceń kapłańskich, „Łódzkie Studia Teologiczne” nr 3 (1994), s. 305-312.

Czaczkowska C., Kardynał Wyszyński. Autorytety, Warszawa 2009.

Franciszek, Służba Kościołowi powszechnemu i Kościołom partykularnym. Bożonarodzeniowe spotkanie z Kuriq Rzymska (21.12.2014), „L`Osservatore Romano” nr 2 (2014), s. $14-15$.

Jastrzębski J., Paragraf w sercu. Kardynał Stefan Wyszyński o miłości i sprawiedliwości społecznej, Kraków 2014.

Kron F. W., Sofos A., Dydaktyka mediów, Gdańsk 2008.

Korszyński F., Redaktor Ateneum Kapłańskiego - biskupem lubelskim, „Ateneum Kapłańskie" nr 45 (1946), s. 3-10.

Laskowska M., Postulaty etyczne dla mediów w publicystyce ks. Stefana Wyszyńskiego, „Kultura-Media-Teologia” nr 3 (2010), s. 92-104.

Lewandowska K., Kardynał Stefan Wyszyński - obrońca historii, tradycji i kultury polskiej, „Perspectiva. Legnickie Studia Teologiczno-Historyczne” nr 1 (2012), s. 59-78.

Łysakowski P., Prymas Wyszyński - twórca polsko-niemieckiego dialogu i pojednania, „Komentarze Historyczne IPN" nr 2018, s. 72-83.

Nęcek R., Państwo w nauczaniu społecznym Prymasa Polski Stefana Wyszyńskiego, Kraków 2004.

Nęcek R., Citizens obligations towards the state in the context of the homiletics of the Primate of Poland Stefan Wyszyński, „Studia Theologica Varsaviensia” nr 2 (2018), s. 83-101.

Romaniuk M. P., Prymas Tysiq̨clecia w pamięci Polaków 1981-2011, Warszawa 2011.

Sitarz M., Stefan Wyszyński - od dzieciństwa do absolwenta KUL, w: Stefan Wyszyński Prymas Tysiąclecia - absolwent KUL kandydat na ołtarze, red. M. Sitarz, A. Słowikowska, A. Romanko, Lublin 2017, s. 24-30.

Tunak M., Pomiędzy partiq a Kościołem. Komu służyła grupa Piaseckiego? (17.11.2017), w: https://historia.org.pl/2017/11/07/pomiedzy-partia-a-kosciolem-komu-sluzylagrupa-piaseckiego/ 
Wyszyński S., Ratujmy nasze człowieczeństwo i życie narodu. Do lekarzy (Warszawa, 23.03.1969), w: Nauczanie społeczne 1946-1981, Warszawa 1991.

Wyszyński S. O „Porozumieniu (Rywałd koło Lidzbarka, 27.09.1953). W: S. Wyszyński. Dzieła zebrane 1949-1953. T. I. Warszawa 1991, s. 262.

Wyszyński S., Kościół $w$ wymiarze międzynarodowym. Do duchowieństwa stolicy (2.08.1975), w: Nauczanie społeczne 1946-1981, Warszawa 1991.

Wyszyński S., Moc żywej wiary w ciężkiej sytuacji Kościoła. Do duchowieństwa (Gdańsk, 23.10.1960), w: Nauczanie społeczne 1946-1981, Warszawa 1991.

Wyszyński S., Czekamy na człowieka! Podczas uroczystości błogosławionego Władysława z Gielniowa, patrona stolicy (25.09.1961), w: Nauczanie społeczne 1946-1981, Warszawa 1991.

Wyszyński S., Z rozważań nad kultura ojczystą, Poznań-Warszawa 1979.

Wyszyński S., Katolicyzm w obliczu zagadnień współczesności. Rozmowa red. Turowicza z Księdzem Prymasem (Gniezno, marzec 1953), w: S. Wyszyński, Dzieła zebrane 1953-1956, t. II, Warszawa 1995.

\section{Biogram}

Robert Nęcek - ksiądz archidiecezji krakowskiej, doktor habilitowany nauk społecznych, kierownik Katedry Edukacji Medialnej w Instytucie Dziennikarstwa i Komunikacji Społecznej na Wydziale Nauk Społecznych Uniwersytetu Papieskiego Jana Pawła II. Konsultor Rady ds. Środków Społecznego Przekazu Konferencji Episkopatu Polski. W latach 2005-2016 rzecznik prasowy Archidiecezji Krakowskiej. Na wniosek Komisji ds. Nagród Rektorskich UPJPII rektor przyznał mu nagrodę za wybitne osiągnięcia dydaktyczne i organizacyjne $(2010,2017)$. Autor wielu artykułów i książek naukowych w Polsce, Niemczech, Austrii, na Słowacji, w Indiach, Hiszpanii i we Włoszech. Wymieniony przez rektora UP JPII jako należący do 23 pracujących na tejże uczelni nauczycieli akademickich, którzy uzyskali najwyższe wyniki w ramach oceny wydziałowej za okres od 1 stycznia 2013 do 31 grudnia 2016 roku. Wyróżniony medalem Mater Verbi. W 2016 roku odznaczony złotą odznaką św. Floriana Mazovia II klasy za wyjątkową skuteczność i kompetencje medialne. Laureat nagrody Feniksa Specjalnego 2017.

ORCID: 0000-0001-8576-9908 